no.

W-92-1

c. 2

Corps neers

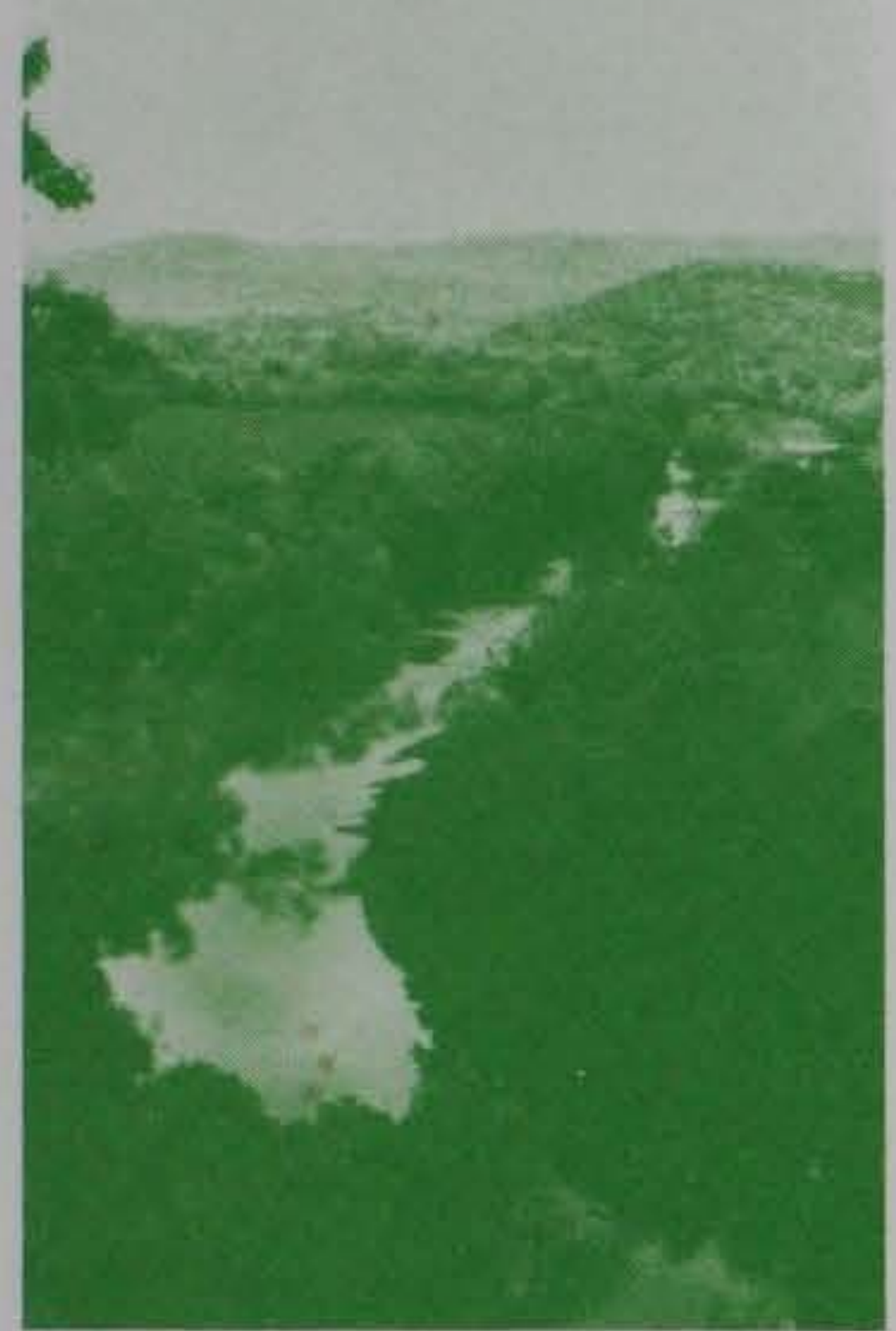

3

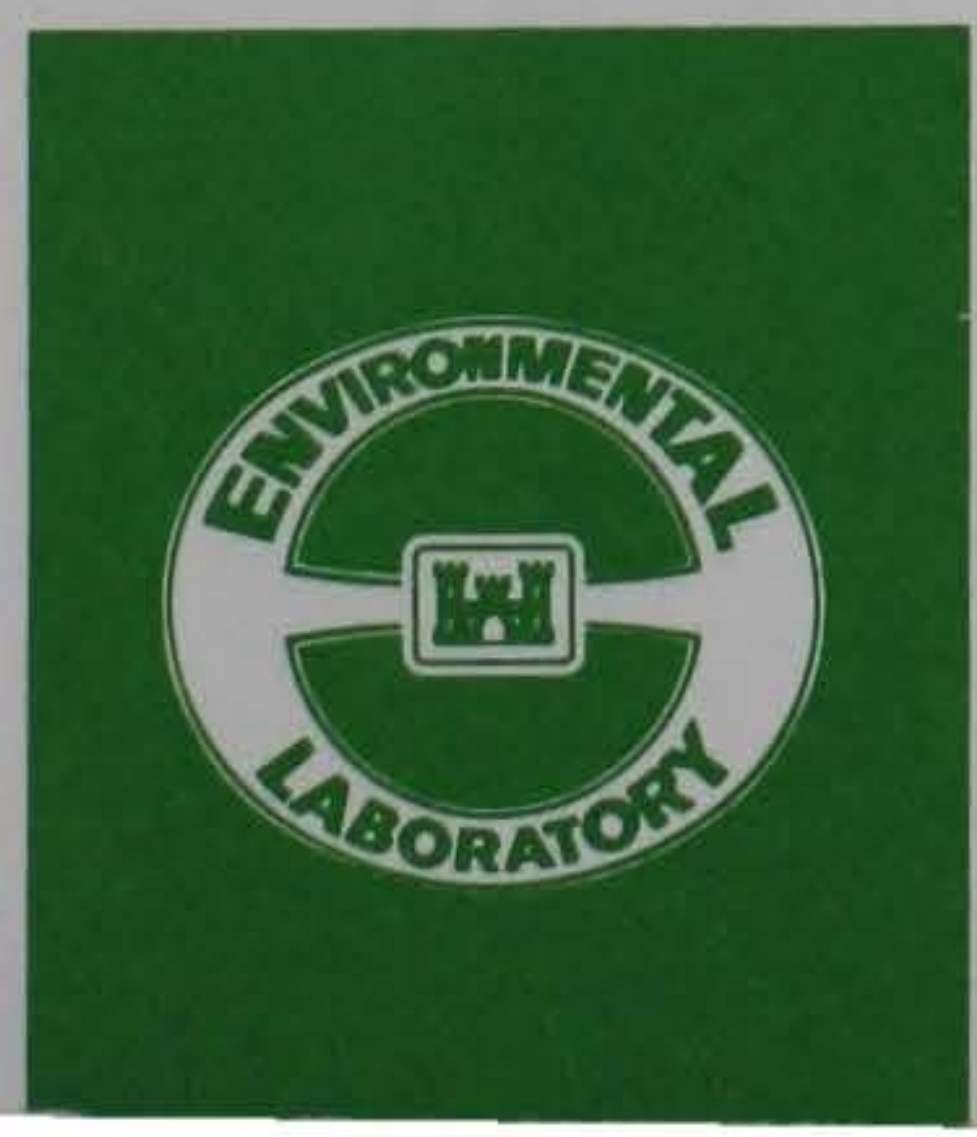

WATER QUALITY

RESEARCH PROGRAM

TECHNICAL REPORT W-92-1

\title{
MODELING WATER QUALITY OF RESERVOIR TAILWATERS
}

\author{
by \\ Mark S. Dortch, Dorothy H. Tillman, Barry W. Bunch \\ Environmental Laboratory \\ DEPARTMENT OF THE ARMY \\ Waterways Experiment Station, Corps of Engineers \\ 3909 Halls Ferry Road, Vicksburg, Mississippi 39180-6199

\section{US-CE-C PROPERTY OF THE UNITED STATES GOVERNMENT}

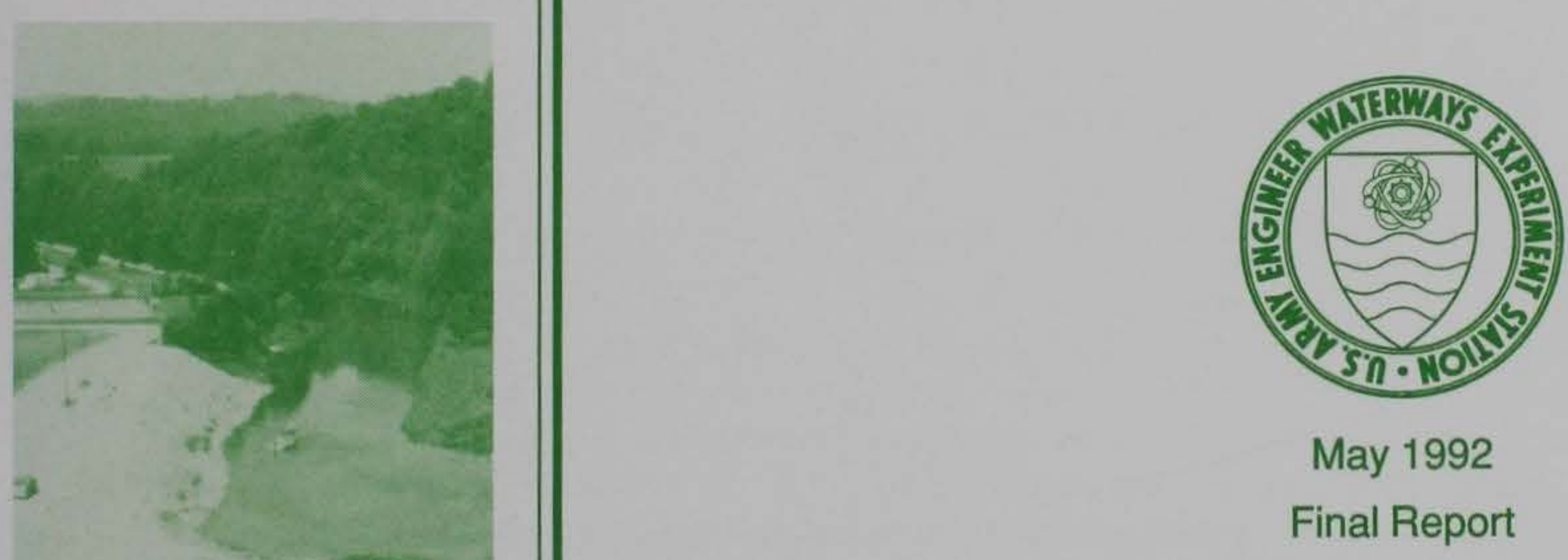

Approved For Public Release; Distribution Is Unlimited

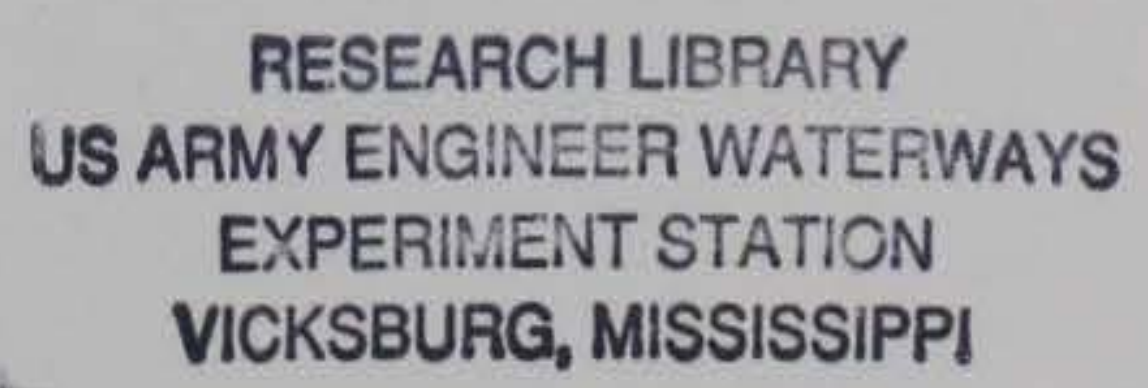

Prepared for DEPARTMENT OF THE ARMY US Army Corps of Engineers Washington, DC 20314-1000 Under WQRP Work Unit 32368 
Public reporting burden for this collection of information is estimated to average I hour per response, including the time for reviewing instructions. searching existing data sources. gathering and maintaining the data needed, and completing and reviewing the collection of information. Send comments regarding this burden estimate or any other aspect of this collection of information, including suggestions for reducing this burden, to Washington Headquarters Services, Directorate for information Operations and Reports, 1215 jefferson Davis Highway, Suite 1204, Arlington, VA 22202-4302, and to the Office of Management and Budget, Paperwork Reduction Project (0704-0188), Washington, DC 20503.

\begin{tabular}{|l|c|c|}
\hline 1. AGENCY USE ONLY (Leave blank) & $\begin{array}{c}\text { 2. REPORT DATE } \\
\text { May } 1992\end{array}$ & $\begin{array}{c}\text { 3. REPORT TYPE AND DATES COVERED } \\
\text { Final report }\end{array}$ \\
\hline
\end{tabular}

4. TITLE AND SUBTITLE

Modeling Water Quality of Reservoir Tailwaters

\section{AUTHOR(S)}

Mark S. Dortch, Dorothy H. Tillman, Barry W. Bunch

\section{PERFORMING ORGANIZATION NAME(S) AND ADDRESS(ES)}

USAE Waterways Experiment Station

Environmental Laboratory

3909 Halls Ferry Road, Vicksburg, MS 39180-6199

9. SPONSORING/MONITORING AGENCY NAME(S) AND ADDRESS(ES)

US Army Corps of Engineers, Washington, DC 20314-1000
5. FUNDING NUMBERS

WU 32368

8. PERFORMING ORGANIZATION REPORT NUMBER

Technical Report W- $92-1$

10. SPONSORING/MONITORING AGENCY REPORT NUMBER

\section{SUPPLEMENTARY NOTES}

Available from National Technical Information Service, 5285 Port Royal Road, Springfield, VA 22161

Approved for pub1ic release; distribution is unlimited.

\section{ABSTRACT (Maximum 200 words)}

Results from field studies of water quality downstream of reservoirs are analyzed to obtain an improved understanding of the mechanisms and chemical transformations occurring in reservoir tailwaters. The research focuses on the poor water quality (e.g., low dissolved oxygen and increased concentrations of reduced substances, such as iron, manganese, and sulfide) associated with deep, anoxic releases from hydropower and nonhydropower dams. In some cases, the analyses confirmed kinetic models that describe the change in constituent concentration with time and resulted in relationships to estimate kinetic rate coefficients. Results were used to develop a model of tailwater quality, and the model was validated with data from the field studies. A description of the model and a model user guide are also included.

\begin{tabular}{|l|l|}
\hline 14. SUBJECT TERMS & Kinetics \\
& $\begin{array}{l}\text { Modeling } \\
\text { Reduced substances }\end{array}$ \\
\hline $\begin{array}{l}\text { 17. SECURITY CLASSIFICATION } \\
\text { OF REPORT } \\
\text { UNCLASSIFIED }\end{array}$ & $\begin{array}{l}\text { 18. SECURITY CLASSIFICATION } \\
\text { OF THIS PAGE } \\
\text { UNCLASSIFIED }\end{array}$ \\
\hline
\end{tabular}

Reservoir tailwaters

Water quality

19. SECURITY CLASSIFICATION OF ABSTRACT 
The work reported herein was conducted as part of the Water Quality Research Program (WQRP), Work Unit 32368. The WQRP is sponsored by the Headquarters, US Army Corps of Engineers (HQUSACE), and is assigned to the US Army Engineer Waterways Experiment Station (WES) under the purview of the Environmental Laboratory (EL). Funding was provided under Department of the Army Appropriation No. 96X3121, General Investigation. The WQRP is managed under the Environmental Resources Research and Assistance Programs (ERRAP), Mr. J. L. Decel1, Manager. Mr. Robert C. Gunkel was Assistant Manager, ERRAP, for the WQRP. Technical Monitors during this study were Messrs. Pete Juhle and James Gottesman and Dr. John Bushman, HQUSACE.

Principal Investigators for the study were Dr. Mark S. Dortch and Ms. Dorothy H. Tillman of the Water Quality Modeling Group (WQMG), Ecosystem Research and Simulation Division (ERSD), EL. This report was prepared by Dr. Dortch, Ms. Tillman, and Dr. Barry Bunch of the WQMG under the direct supervision of Dr. Dortch, Chief, WQMG, and under the general supervision of Mr. Donald L. Robey, Chief, ERSD, and Dr. John Harrison, Director, EL. The report was reviewed by Mr. Tom Cole of WQMG; Drs. Robert Kennedy and James Brannon of the Aquatic Processes and Effects Group, ERSD; and Dr. Joe Nix, Department of Chemistry, Ouachita Baptist University, Arkadelphia, AR.

At the time of publication of this report, Director of WES was Dr. Robert W. Whalin. Commander and Deputy Director was COL Leonard G. Hasse11, EN.

This report should be cited as follows:

Dortch, Mark S., Tillman, Dorothy H., and Bunch, Barry W. 1992. "Modeling Water Quality of Reservoir Tailwaters," Technical Report W-92-1, US Army Engineer Waterways Experiment Station, Vicksburg, MS. 
PREFACE

CONVERSION FACTORS, NON-SI TO SI (METRIC) UNITS OF MEASUREMENT . • $\quad 3$

PART I: INTRODUCTION . . . . . . . . . . . . . . . . . . . . . . 4

Background . . . . . . . . . . . . . . . . . . . . . . . . . 4

Objectives . . . . . . . . . . . . . . . . . . . . . . . . . 4

Approach . . . . . . . . . . . . . . . . . . . . . . . . . . 5

PART II: DESCRIPTIONS OF TAILWATER QUALITY PROCESSES . . . . . . . 8

Model Basis . . . . . . . . . . . . . . . . . . . . . . . . . 8

Manganese . . . . . . . . . . . . . . . . . . . . . . . . . . 9

Iron . . . . . . . . . . . . . . . . . . . . . . . . . . 11

Sulfide... . . . . . . . . . . . . . . . . . . . . . . . . . . . . 13

Other Water Quality Constituents . . . . . . . . . . . . . . 16

PART III: DATA ANALYSES . . . . . . . . . . . . . . . . . . . . . . . 22

Reduced Manganese Removal . . . . . . . . . . . . . . . . . . 22

Reduced Iron Removal . . . . . . . . . . . . . . . . . . . . 31

Sulfide Removal . . . . . . . . . . . . . . . . . . . . 34

Nitrification... . . . . . . . . . . . . . . . . . . . . . . . 35

PART IV: NUMERICAL MODEL . . . . . . . . . . . . . . . . . . . . . 38

Description . . . . . . . . . . . . . . . . . . . . . . . . 38

Application . . . . . . . . . . . . . . . . . . . . . . 51

PART V: CONCLUSIONS AND RECOMMENDATIONS . . . . . . . . . . . . . . . 68

REFERENCES . . . . . . . . . . . . . . . . . . . . . . . . . . . . . . . 71

APPENDIX A: 1989 NIMROD TAILWATER DATA . . . . . . . . . . . . . . . A1

APPENDIX B: MODEL OPERATION . . . . . . . . . . . . . . . . . . . . B1

APPENDIX C: KINETIC RATE REGRESSIONS . . . . . . . . . . . . . . . . C1

APPENDIX D: NOTATION . . . . . . . . . . . . . . . . . . . . . . . . . D1 


\section{CONVERSION FACTORS, NON-SI TO SI (METRIC) \\ UNITS OF MEASUREMENT}
Non-SI units of measurement used in this report can be converted to SI (metric) units as follows:
Multiply
cubic feet
feet
miles (US statute)
By
0.02831685
0.3048
1.609347
To Obtain
cubic meters
meters
kilometers 


\section{PREDICTING WATER QUALITY OF}

\section{RESERVOIR TAILWATERS}

\section{PART I: INTRODUCTION}

\section{Background}

1. Thermal stratification in reservoirs is often accompanied by depletion of dissolved oxygen (DO) in the bottom waters (hypolimnion). Oxygen depletion and the establishment of reducing conditions in the hypolimnion increase mobilization from the sediments of dissolved nutrients (i.e., ammonium and inorganic phosphorus), sulfide, reduced metals (e.g., iron and manganese), and organic substances (i.e., simple organic acids and methane). These substances can accumulate in the hypolimnion, thus impacting in-pool and release water quality. Reservoir releases that are low in DO and high in reduced substances can threaten aquatic life, cause water treatment problems for downstream water supply, and can be obnoxious to downstream recreational users.

2. When water is released to the downstream environment, stream reaeration occurs and reduced substances begin to oxidize (Stumm and Morgan 1981). Water quality improves as the water moves downstream, eventually recovering to a more natural stream condition. The recovery distance, which depends on site-specific physical, chemical, and biological processes, is often on the order of tens of miles (Nix et al. 1991).

3. A better understanding of the recovery mechanisms and chemical transformations in tailwaters is needed to be able to address issues concerning reservoir tailwater quality and to better manage tailwater quality problems. As a result of this need, a research work unit, entitled "Techniques for Evaluating Water Quality of Reservoir Tailwaters," was initiated in the Water Quality Research Program. Since surface releases generally contain DO and are void of troublesome reduced substances, this research focused on degraded water quality downstream of dams with deep, anoxic releases.

\section{Objectives}

4. The objectives of this research were to: 
a. Develop an improved understanding of chemical transformations in reservoir tailwaters.

b. Provide guidance on sampling and analysis of tailwater quality.

c. Develop an easy-to-use personal computer (PC) model to predict water quality of reservoir tailwaters given in-pool or release concentrations.

This report is the second of two reports produced from this research work unit and addresses Objectives $\underline{a}$ and $\underline{c}$ above. Objective $\underline{b}$ was addressed in a report by Nix et al. (1991). Nix et al. (1991) present field study results for four study sites. One of the study sites, Nimrod tailwater, was revisited in 1989 to gain additional information. Those data are presented in Appendix A. Results from the four field study sites are analyzed herein to obtain an improved capability for predicting the time-dependent changes in reduced substances (e.g., reduced iron and manganese) in reservoir tailwaters. A numerical water quality model for reservoir tailwaters was developed and is presented in Part IV and Appendix B. Appendix C presents the kinetic rate regressions.

\section{Approach}

5. Effective water quality management of reservoir tailwaters requires assessment of existing conditions and prediction of future conditions resulting from structural and/or operational modifications of the dam or tailwater system. For example, the conversion of a nonhydropower, deep release to a hydropower release can lead to water quality problems. Releases through hydropower turbines are not subjected to the usually high degree of reaeration to which nonhydropower releases are subjected (Bohac, Harshbarger, and Lewis 1983); thus, low DO may persist for a number of miles downstream, which is detrimental to downstream aquatic habitat.

6. Mathematical water quality modeling is a cost-effective tool for predicting future conditions resulting from human actions (McCutcheon 1989). A model can be used to estimate downstream water quality for a proposed release condition at a dam. However, water quality models are limited in the context of process descriptions. For example, consider a first-order loss or decay of a substance (e.g., biochemical oxygen demand). First-order loss or decay occurs when the time rate of change of a constituent concentration $C$ is directly proportional to the concentration, which is mathematically stated as 


$$
\frac{d C}{d t}=-K C
$$

where $t$ is time.* Equation 1 has been successfully used to describe the kinetics of numerous water quality constituents. The difficulty in applying Equation 1 in practice is estimating or calibrating the reaction coefficient, $K$. The modeler usually tries to fit the model to observed concentrations by varying $\mathrm{K}$ during calibration. In reality, $\mathrm{K}$ can vary with environmental conditions, such as temperature, $\mathrm{pH}$, DO, etc. One of the greatest difficulties of water quality modeling is that information on the processes that affect $\mathrm{K}$ is limited. Therefore, empirical observations are required to develop $\mathrm{K}$ values for site-specific conditions. Improved understanding of the physicochemical processes is required for more general application of water quality models.

7. An improved understanding of water quality processes can be obtained through carefully designed field study because laboratory studies may fail to include all environmental factors that affect water quality kinetics. Shortterm intensive field studies were conducted at four reservoir tailwater sites where physical and water quality conditions were measured to quantify chemical transformations. The study sites were Little Missouri River, Arkansas, below Lake Greeson; Fourche La Fave River, Arkansas, below Nimrod Reservoir; Rough River, Kentucky, below Rough River Reservoir; and Guadalupe River, Texas, below Canyon Reservoir. Narrows Dam (i.e., Lake Greeson) has hydropower; Canyon Dam was retrofitted for non-Federal hydropower shortly after this study. The other sites are nonhydropower. All sites had deep releases characterized by the presence of reduced substances with low DO. The study sites provided a range of physical and environmental conditions, such as varying stream slope, substrate, and $\mathrm{pH}$.

8. Samples were collected for water quality analyses at a number of stations extending over the tailwater reaches. The study reaches extended from the dam to about 10 to 36 river kilometers downstream, depending on flow conditions and stream characteristics, both of which impact particle travel time. Particle travel time is the time required for a parcel of water to move

* For convenience, symbols and abbreviations are listed in the Notation (Appendix D). 
from the release point to a given distance downstream. The study reaches were generally limited to a travel time of about 2 days, because most of the chemical reactions occurred within this time period.

9. The release flow rate from the dam was held constant during each field study to provide steady flow and nearly steady-state conditions (with the exception of diel effects). This approach greatly simplifies interpretation of results. Lagrangian sampling, which tracks a water parcel as it moves downstream, and snapshot sampling, in which samples are collected at all stations at or near the same point in time, yielded similar results for steady flows (Nix et al. 1991), which means the systems were approximately at steady state. Dye studies were conducted to determine the travel time to each station. With concentrations measured at the stations and with known travel time to the stations, it is possible to evaluate the reaction kinetics of Equation 1 for various processes, such as the loss of reduced manganese. Part II of this report describes tailwater quality processes based upon literature review. Part III presents the analyses of the field studies for use in model development, and Part IV presents the numerical model and its application to the field study sites. 


\section{PART II: DESCRIPTIONS OF TAILWATER QUALITY PROCESSES}

\section{Model Basis}

10. It is useful to first present the fundamental model that will be used to model water quality of reservoir tailwaters. The mathematical model is based on the one-dimensional (1-D) mass conservation equation for streams

$$
\frac{\partial C}{\partial t}+U\left(\frac{\partial C}{\partial x}\right)=D\left(\frac{\partial^{2} C}{\partial x^{2}}\right) \pm S
$$

where

$$
\begin{aligned}
\mathrm{U}= & \text { stream mean velocity } \\
\mathrm{X}= & \text { distance downstream } \\
\mathrm{D}= & \text { longitudinal dispersion } \\
\mathrm{S}= & \text { rate of change in concentration resulting from transformation or } \\
& \text { chemical reactions }
\end{aligned}
$$

Equation 2 assumes completely mixed conditions over the depth and width of the stream. The dispersion term, which is the first term on the right side of Equation 2, is usually much less than advection (second term on the left side of Equation 2) for streamflow (Fischer et al. 1979). Neglecting dispersion, assuming steady-state conditions, and changing from an Eulerian to a Lagrangian reference frame, where $U=d x / d t$ is the velocity of a parcel of water, Equation 2 can be simplified to

$$
\frac{d C}{d t}= \pm s
$$

If $S$ in Equation 3 is a first-order loss rate (i.e., $-\mathrm{KC}$ ), Equation 3 is identical to Equation 1.

11. The Eulerian viewer observes concentrations at multiple stream stations as the water flows by; the Lagrangian viewer follows a parcel of water as it flows downstream and observes its concentration. The analyses in the following sections use the Lagrangian view because it conveniently relates results from all field study sites to a common variable, travel time of a parcel of water. However, the numerical model discussed in Part IV uses the 
Eulerian view, but assumes steady flow and steady-state conditions. Therefore, the two views are still equivalent.

\section{Manganese}

12. Anoxic conditions in the hypolimnion of deep reservoirs induce the formation of dissolved, reduced manganese, $\mathrm{Mn}^{+2}$ or $\mathrm{Mn}$ (II). Reduced manganese can accumulate in the reservoir, affecting in-pool as well as release water quality. $\mathrm{Mn}^{+2}$ accumulates in the water column from sediment release and reduction of $\mathrm{Mn}$ (IV) in the water column under anoxic conditions, and $\mathrm{Mn}^{+2}$ is mostly in the dissolved state with particulate $\mathrm{Mn}^{+2}$ being negligible (Wilson 1980).

13. Little work has been conducted to evaluate the fate of reduced substances after they are released to the tailwater system (Gordon 1983). The oxidation of reduced manganese in the tailwater can be influenced by many environmental factors such as temperature, $\mathrm{pH}$, presence of DO, electron acceptors, degree of mixing, etc. (Gordon 1989). In an effort to observe the fate of reduced manganese spatially in the Duck River, Gordon conducted a field study below Normandy Dam, near Tullahoma, TN (Gordon 1989). Gordon found from the Duck River field data that the manganese removal rate was first-order with time of travel, and the reaction rate was much faster than that typically found in laboratory studies. He also found that the removal rate was a function of river discharge.

14. The removal of reduced $\mathrm{Mn}^{+2}$ from reservoir tailwaters can involve physical processes (i.e., adsorption) as well as oxidation. Nix (1986), Gordon (1989), and Gordon and Burr (1989) have found that a primary removal process of $\mathrm{Mn}^{+2}$ can involve adsorption of $\mathrm{Mn}^{+2}$ onto an oxide-coated substrate. Stumm and Morgan (1981) suggest that once the $\mathrm{Mn}^{+2}$ is adsorbed onto the substrate, oxidation on the manganese oxide surface is a slow process. Hsiung (1987) reported that reduced manganese is removed primarily by oxidation for $\mathrm{pH}$ above 9.0 and by surface catalysis at lower $\mathrm{pH}$. Wilson (1980) also suggests that the removal of $\mathrm{Mn}^{+2}$ during the turnover of lakes is probably through adsorption onto particulate matter and co-precipitation followed by slow oxidation.

15. Work by Nix (1986) showed that gravel coated with hydrous manganese oxides from the tailwater of Narrows Dam (Lake Greeson) effectively removed reduced manganese in the laboratory, whereas removal without the gravel was 
slow. Data from the study sites report by Nix et al. (1991) indicate that total and dissolved manganese both consistently decrease in the downstream direction, suggesting an adsorption removal mechanism. If only water column oxidation was occurring without adsorption onto the bottom, one would think that the stream turbulence would be sufficient to keep particulate (i.e., oxidized) manganese suspended, thus holding the total manganese concentrations relatively constant rather than decreasing as observed.

16. Gordon (1989) found through laboratory experiments that reduced manganese removal was associated with a "slime" found on rock surfaces in the Duck River below Normandy Dam. Gordon and Burr (1989) were able to effectively remove reduced manganese using columns packed with glass marbles acclimated with the slimy black coating characteristic of the Duck River stones. The results of these studies all indicate the need to consider the substrate as a primary removal mechanism of $\mathrm{Mn}^{+2}$ in the tailwater.

17. During some earlier work, Dortch and Hamlin (1988) hypothesized that flow rate impacted the manganese removal rate in the Lake Greeson tailwater. The reasoning behind this hypothesis was that if adsorption onto the substrate is a primary removal mechanism, then altering the streamflow rate changes the ratio of bottom contact area to cross-sectional flow area, which is equivalent to altering the hydraulic depth. Thus, higher flow rates, with greater depths, should be less effective in removing dissolved manganese; this was found to be true for the Greeson tailwater.

18. Hess, Byung, and Roberts (1989) developed a manganese model using the Duck River data and subsequently applied the model to the Chattahoochee River below Buford Dam, Georgia. This model contained two removal mechanisms, homogeneous and heterogeneous oxidation. Homogeneous oxidation is direct oxidation of $\mathrm{Mn}^{+2}$ in the water, and heterogeneous removal involves catalytic activity (i.e., sorption and oxidation) with available surfaces (i.e., hydrous manganese oxides and suspended particulates). The Hess model for manganese reaction is based on the work of Morgan (1967), which states

$$
\frac{d[\mathrm{Mn}(\mathrm{II})]}{\mathrm{dt}}=-\left(\mathrm{k}_{0}\left[\mathrm{OH}^{-}\right]^{2}[\mathrm{DO}]+\mathrm{k}\left[\mathrm{OH}^{-}\right]^{2}[\mathrm{DO}][\mathrm{Mn}(\mathrm{IV})]\right)[\mathrm{Mn}(\mathrm{II})]
$$


where

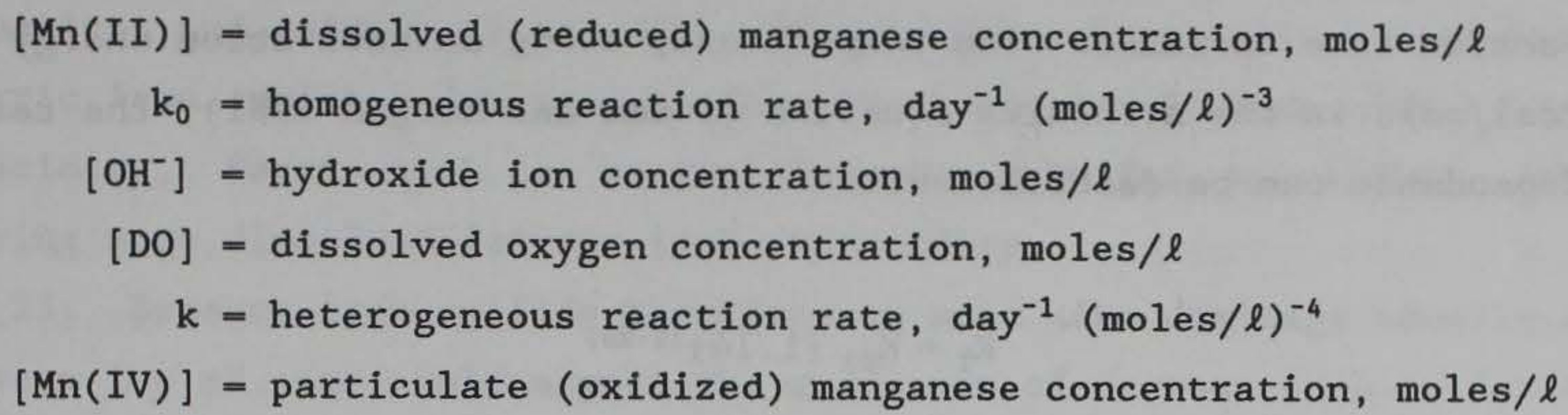

Morgan (1967) found that the rate constants are temperature dependent. Hess, Byung, and Roberts (1989) reported that $\mathrm{pH}$ has a much greater effect on the manganese oxidation rate than dissolved oxygen concentration.

19. The major limitation of the Hess model is that it does not include sorption of manganese onto the channel bottom (substrate). The ideas developed in Equation 4 provide a good starting point for analyzing the data obtained within the present study, provided that the effects of substrate adsorption are included.

\section{Iron}

20. The rate of oxidation of reduced iron (i.e., ferrous iron, $\mathrm{Fe}^{++}$, $\mathrm{Fe}(\mathrm{II})$ ) is first-order with respect to concentrations of $\mathrm{Fe}(\mathrm{II})$ and $\mathrm{O}_{2}$ and inverse second-order with respect to the $\mathrm{H}^{+}$concentration (i.e., $\left[\mathrm{H}^{+}\right]$in moles/ $\ell$ where $\left[\mathrm{H}^{+}\right]=10^{-\mathrm{pH}}$ ) in solutions of $\mathrm{pH}>5$ (Stumm and Morgan 1981). This rate law is expressed as

$$
\frac{\mathrm{d}[\mathrm{Fe}(\mathrm{II})]}{\mathrm{dt}}=-\mathrm{k}_{\mathrm{Fe}} \frac{[\mathrm{Fe}(\mathrm{II})][\mathrm{DO}]}{\left[\mathrm{H}^{+}\right]^{2}}
$$

where $[\mathrm{Fe}(\mathrm{II})]$ is the concentration in moles/ $\ell$ of ferrous iron and $\mathrm{k}_{\mathrm{Fe}}=3.0 \times 10^{-12} \mathrm{moles} / \ell \mathrm{min}^{-1}$ at $20^{\circ} \mathrm{C}$. Equation 5 is in the form of Equation 1 with the overall reaction rate for ferrous iron described as

$$
\mathrm{K}_{\mathrm{Fe}}=\mathrm{k}_{\mathrm{Fe}} \frac{[\mathrm{DO}]}{\left[\mathrm{H}^{+}\right]^{2}}
$$


The reaction rate increases with temperature; using an activation energy of $23.0 \mathrm{kcal} / \mathrm{mole}$ in the Arrhenius equation (Stumm and Morgan 1981), the temperature dependence can be described with

$$
\mathrm{K}_{\mathrm{T}}=\mathrm{K}_{20}(1.14)^{(\mathrm{T}-20)}
$$

where

$$
\begin{aligned}
\mathrm{K}_{\mathrm{T}} & =\text { reaction rate at temperature } \mathrm{T},{ }^{\circ} \mathrm{C} \\
\mathrm{K}_{20} & =\text { reaction rate at } 20{ }^{\circ} \mathrm{C}
\end{aligned}
$$

Sung and Morgan (1980) concluded that temperature dependence is primarily a result of the change in the $\mathrm{H}^{+}$concentration due to the temperature dependence of the ionization constant of water.

21. Sung and Morgan (1980) also reported that the rate constant (i.e., $\mathrm{k}_{\mathrm{Fe}}$ of Equation 5) is inversely proportional to ionic strength and individual anions (e.g., $\mathrm{Cl}^{-}$and $\mathrm{SO}_{4}^{-2}$ ). For example, in the $\mathrm{pH}$ range of 6.5 to 7.2 , sulfate ions have a significant retarding influence on the oxygenation rate. For $\mathrm{pH}$ of about 7 or greater, data indicate an autocatalytic rate expression, i.e., homogeneous and heterogeneous oxidations with the latter involving adsorption of ferrous iron by ferric hydroxide (Sung and Morgan 1980). Sarikaya (1990) proposed recycling of ferric sludge at treatment plants to provide effective catalytic removal of ferrous iron, thus reducing volumes required for aeration tanks.

22. As reducing conditions progress in anoxic reservoir bottom sediments, sulfate reduction follows iron reduction, and iron sulfide forms (Stumm and Morgan 1981, Wetzel 1975). Although iron sulfide is insoluble at the $\mathrm{pH}$ conditions typically found in reservoir waters, iron sulfide may be temporari1y suspended in the water column and released to the tailwater.

23. The presence of iron sulfide in the tailwater can complicate the understanding of ferrous iron and sulfide reactions. Generally, not enough $\mathrm{H}_{2} \mathrm{~S}$ is available for pyrite $\left(\mathrm{FeS}_{2}\right)$ formation; thus, iron sulfide should exist as $\mathrm{FeS}$ in fresh water (Berner 1980). The oxidation of FeS is rapid. Connell (1966) showed that $120 \mathrm{ppm}$ total sulfides in a soil was reduced to $5 \mathrm{ppm}$ after $2 \mathrm{hr}$ of exposure to air; this translates into an oxidation rate of about 38.0 day $^{-1}$.

24. The reactions for $\mathrm{FeS}_{2}$ should be somewhat similar to those that occur in streams subjected to acid mine drainage as explained by stumm and 
Morgan (1981). The sulfide of $\mathrm{FeS}_{2}$ is oxidized to sulfate-releasing dissolved ferrous iron and acidity $\left(i . e ., \mathrm{H}^{+}\right.$). Subsequently, ferrous iron is oxidized to ferric iron, which hydrolyzes to form insoluble ferric hydroxide, releasing more acidity. Ferric iron can be rapidly reduced by $\mathrm{FeS}_{2}$ to oxidize sulfide, releasing more dissolved ferrous iron and acidity.

25. Because iron sulfide reactions in acid mine drainage usually occur with very low $\mathrm{pH}$, one would expect the oxidation of ferrous iron to ferric iron to be slow. In fact, the rate of oxidation of ferrous iron for low $\mathrm{pH}$ (i.e., pH below 4 to 5 ) is controlled primarily by the action of autotrophic iron-oxidizing bacteria rather than chemical oxidation (Stumm and Morgan 1981; Noike, Kanji, and Jun'Ichiro 1983). However, Noike, Kanji, and Jun'Ichiro (1983) found ferrous iron oxidation rates between 25.9 and 49.0 day $^{-1}$ in a low-pH stream ( $\mathrm{pH} 1.5$ to 2.9 ) receiving acid mine drainage. These rates are comparable to those that occur at the higher $\mathrm{pH}$ values found in natural waters. The oxidation of sulfide by oxygen or hydroxides also occurs rapidly. Stumm and Morgan (1981) report half-times on the order of 20 to 1,000 min for oxidation of iron sulfide by ferric hydroxide; this corresponds to reaction rates of 50 day $^{-1}$ to 1 day $^{-1}$.

\section{$\underline{\text { Sulfide }}$}

26. Dissolved sulfide, $\mathrm{S}[-\mathrm{II}]$, can exist as hydrogen sulfide $\left(\mathrm{H}_{2} \mathrm{~S}\right)$, bisulfide ion $\left(\mathrm{HS}^{-}\right)$, and $\mathrm{S}^{-2}$. Negligible amounts (less than 0.5 percent) of dissolved sulfide exist as $\mathrm{s}^{-2}$ for the $\mathrm{pH}$ range of most streams and lakes; the distribution between $\mathrm{HS}-$ and $\mathrm{H}_{2} \mathrm{~S}$ varies with $\mathrm{pH}$, with high $\mathrm{pH}$ favoring $\mathrm{HS}^{-}$and low $\mathrm{pH}$ favoring $\mathrm{H}_{2} \mathrm{~S}$ (American Public Health Association et al. 1981). At a $\mathrm{pH}$ of 7.0, sulfide exists as about half hydrogen sulfide and half bisulfide ion. Hydrogen sulfide can be removed from the water through volatilization and oxidation, although oxidation of $\mathrm{H}_{2} \mathrm{~S}$ occurs very slowly compared with oxidation of $\mathrm{HS}^{-}$(Millero 1986). $\mathrm{HS}^{-}$is removed primarily by oxidation.

27. The general consensus from the literature is that oxidation kinetics of sulfide in natural waters is very complex and poorly understood (Chen and Morris 1972a, Stumm and Morgan 1981, Millero 1986). Based upon the review by Millero (1986), the oxidation of sulfide can be described as firstorder with respect to $\mathrm{HS}^{-}$with a rate that increases with increasing temperature, $\mathrm{pH}$, and concentrations of DO, metal ions, and initial sulfide. There is also general agreement that sulfur bacteria play an important role in sulfide 
oxidation in natural and waste waters. These influencing factors help to explain why the first-order sulfide oxidation rates reported vary between 0.26 and about 55.0 day $^{-1}$, which correspond to half-lives between 65.0 and $0.3 \mathrm{hr}$ (Millero 1986).

28. The oxidation rate of sulfide is strongly dependent on $\mathrm{pH}$. For an increase in $\mathrm{pH}$ from about 6.0 to 8.0 , there is an eightfold increase in the rate (Chen and Morris 1972b). Millero (1986) attributes this to the shift in sulfide concentration from predominantly nonreactive $\mathrm{H}_{2} \mathrm{~S}$ to predominantly reactive $\mathrm{HS}^{-}$with increasing $\mathrm{pH}$. This reasoning suggests that $\mathrm{HS}^{-}$concentration, based on $\mathrm{pH}$, should be used in the kinetic equation.

29. Almgren and Hagstrom (1974) found a second-order rate dependence with the oxidation dependent on $[\mathrm{S}(-\mathrm{II})]$ and $\left[\mathrm{O}_{2}\right]$. However, Wilmot et al. (1988) reported that the order of reaction with respect to $\left[\mathrm{O}_{2}\right]$ was only 0.2 rather than 1.0; they preferred to use the Michaelis-Menton law to describe the influence of $\mathrm{DO}$, which is stated as

$$
\frac{d S}{d t}=-k_{s} S \frac{D O}{D_{1 / 2}+D O}
$$

where

$$
\begin{aligned}
\mathrm{S} & =\text { sulfide concentration in the form of } \mathrm{HS}^{-}, \mathrm{mg} / \ell \\
\mathrm{k}_{\mathrm{s}} & =\text { sulfide oxidation rate, day } \\
\mathrm{DO} & =\text { dissolved oxygen concentration, } \mathrm{mg} / \ell \\
\mathrm{DO}_{1 / 2} & =\text { dissolved oxygen half-saturation constant, } \mathrm{mg} / \ell
\end{aligned}
$$

A value of 3.0 was recommended by wilmot et al. (1988) for $\mathrm{DO}_{1 / 2}$. O'Brien and Birkner (1977) reported that the order of reaction with respect to $\left[\mathrm{O}_{2}\right]$ was about 0.8. Chen and Morris (1972a) also found that the variation of rate with DO was less than first-order (e.g., order of about 0.5). These discrepancies are probably related to the different experimental conditions and methods used (Millero 1986). In the absence of better information, Equation 8 is appealing from a modeling standpoint.

30. Ions present in natural waters can enhance sulfide oxidation rates. Almgren and Hagstrom (1974) found fairly high rates of sulfide oxidation for seawater $\left(k_{s}\right.$ on the order of 25.0 day $^{-1}$ ). $0^{\prime}$ Brien and Birkner (1977) reported that sulfide oxidation increases with increasing ionic strength. Paschke, Hwang, and Johnson (1977) found that the use of manganese salts as catalysts 
and adjusting the $\mathrm{pH}$ to 8.5 were effective in removing approximately 90 percent of the sulfide within 1 to $2 \mathrm{hr}$ for wastewater from a cellulose sponge-making operation. This result translates into sulfide oxidation rates between about 27 and 55 day $^{-1}$. Chen and Morris (1972a) also found strong catalytic effects of metal ions, e.g., orders of magnitude reduction in oxidation rates.

31. Sulfide-oxidizing bacteria are also considered to increase the oxidation rate (Chen and Morris 1972a, Wilmot et al. 1988). Wilmot et al. (1988) reported oxidation rates between about 14 and 130 day $^{-1}$ for wastewaters with as much as half of the oxidation attributed to bacteria. Wilmot et al. (1988) also determined that larger initial sulfide concentrations resulted in greater oxidation rates.

32. The sulfide oxidation rate approximately doubles for a $15.0{ }^{\circ} \mathrm{C}$ temperature increase (Wilmot et al. 1988). This dependency on temperature can be represented as

$$
\left(k_{s}\right)_{T}=\left(k_{s}\right)_{20}(1.05)^{(T-20)}
$$

where $\left(k_{s}\right)_{20}$ is the oxidation rate at $20^{\circ} \mathrm{C}$.

33. Hydrogen sulfide $\left(\mathrm{H}_{2} \mathrm{~S}\right)$ is a highly volatile dissolved gas that oxidizes very slowly (Chen and Morris 1972a, 1972b). Therefore, the major loss mechanism is through volatilization from the water. Methods described by Lyman et al. (1982) were used for determining volatilization rates of $\mathrm{H}_{2} \mathrm{~S}$. Henry's constant at $25^{\circ} \mathrm{C}$ for $\mathrm{H}_{2} \mathrm{~S}$ is $1.01 \times 10^{-2} \mathrm{~atm} \mathrm{m^{3 }} / \mathrm{mol}$. Therefore, the transfer is liquid phase controlled, and volatilization can be computed with a first-order rate constant from information on the dissolved oxygen reaeration rate in streams,

$$
K_{s}=K_{2} \frac{D^{s}}{D^{0}}=K_{2} \sqrt{\frac{M^{0}}{M^{8}}}
$$

where

$$
\begin{aligned}
& \mathrm{K}_{\mathrm{s}}=\text { volatilization rate of } \mathrm{H}_{2} \mathrm{~S}, \text { day }^{-1} \\
& \mathrm{~K}_{2}=\text { DO stream reaeration rate, day } \\
& \mathrm{D}^{\mathrm{s}}=\text { molecular diffusivity of } \mathrm{H}_{2} \mathrm{~S}, \mathrm{~cm}^{2} / \mathrm{sec}
\end{aligned}
$$




$$
\begin{aligned}
& D^{\circ}=\text { molecular diffusivity of } \mathrm{DO}, \mathrm{cm}^{2} / \mathrm{sec} \\
& M^{\circ}=\text { molecular weight of } \mathrm{DO}, \mathrm{g} / \mathrm{mole} \\
& M^{5}=\text { molecular weight of } \mathrm{H}_{2} \mathrm{~S}, \mathrm{~g} / \mathrm{mole}
\end{aligned}
$$

Since the molecular weights of hydrogen sulfide and DO are about equal, $\mathrm{K}_{\mathrm{s}}$ is approximately equal to $\mathrm{K}_{2}$. With little or no $\mathrm{H}_{2} \mathrm{~S}$ in the atmosphere, the volatilization (mg/ $/ /$ day) is computed as

$$
\mathrm{J}=-\mathrm{K}_{2} \mathrm{C}_{\mathrm{s}}
$$

where $C_{s}$ is the concentration of $\mathrm{H}_{2} \mathrm{~S}$ in the stream. The stream reaeration rate can be estimated from a variety of mathematical formulations as noted in Appendix B.

\section{Other Water Quality Constituents}

34. Other water quality constituents that are of primary interest in reservoir tailwaters are temperature, dissolved oxygen, and nutrients. Heat exchange mechanisms are relatively well understood, and the capability to accurately model steam temperature is well established (Dortch and Martin 1989). Therefore, there was no emphasis in this research on predicting steam temperature. Dissolved oxygen is required for aquatic life; thus, it is of prime importance in reservoir tailwaters, and the sources and sinks of oxygen must be considered. The nutrients nitrogen and phosphorus can exist in various forms: organic, inorganic, particulate, and dissolved. The only nutrient form that presents an immediate potential problem in tailwaters dominated by anoxic hypolimnetic releases is ammonia. Ammonia is important because oxygen is used during nitrification to nitrate. The photosynthesis, respiration, and nutrient uptake of phytoplankton and macrophytes were not considered in this work because of the relatively minor influence on tailwater quality processes at the sites studied (Nix et al. 1991).

35. Oxidation of reduced substances in the tailwater is a major sink, or loss mechanism, of oxygen (Nix et al. 1991). The primary source of oxygen is stream reaeration. The reactions and their products must be known in order to determine how much oxygen is taken up during oxidation. Once this is known, the stoichiometry for the amount of DO taken up per unit of substance 
oxidized can be specified within the model. Each of the reduced substances discussed above, plus ammonia, is considered below.

36. The oxidation of $\mathrm{Mn}(\mathrm{II})$ may be represented (Benefield, Judkins, and Weand 1982) by

$$
2 \mathrm{Mn}^{+2}+\mathrm{O}_{2}+2 \mathrm{H}_{2} \mathrm{O} \Rightarrow 2 \mathrm{MnO}_{2}+4 \mathrm{H}^{+}
$$

This reaction requires $0.29 \mathrm{mg} / \ell$ of DO to oxidize $1.0 \mathrm{mg} / \ell$ of $\mathrm{Mn}$. However, Stumm and Morgan (1981) point out that experimental findings indicate the extent of Mn(II) removal is not accounted for by the stoichiometry of the oxidation reaction alone, and the products of oxygenation are nonstoichiometric, showing various degrees of oxidation ranging from about 30 to 90 percent oxidation to $\mathrm{MnO}_{2}$. Thirty percent oxidation requires about $0.10 \mathrm{mg} / \ell$ of DO per $1.0 \mathrm{mg} / \ell \mathrm{Mn}$. A DO uptake stoichiometry of $0.29 \mathrm{mg} / \ell \mathrm{per} \mathrm{mg} / \ell$ of $\mathrm{Mn}$ removed can be used as a worst case for modeling.

37. The oxidation of $\mathrm{Fe}$ (II) may be represented (Stumm and Morgan 1981; Benefield, Judkins, and Weand 1982) by

$$
4 \mathrm{Fe}^{+2}+\mathrm{O}_{2}+10 \mathrm{H}_{2} \mathrm{O} \Rightarrow 4 \mathrm{Fe}(\mathrm{OH})_{3}+8 \mathrm{H}^{+}
$$

This reaction requires $0.14 \mathrm{mg} / \ell$ of DO to oxidize $1.0 \mathrm{mg} / \ell$ of $\mathrm{Fe}$ (II). Based on stoichiometry, the total oxidation of FeS to ferric iron and sulfate requires about $0.73 \mathrm{mg} / \ell$ of $\mathrm{DO}$ per $1.0 \mathrm{mg} / \ell$ of $\mathrm{FeS}$, and $\mathrm{FeS}_{2}$ requires about $1.0 \mathrm{mg} / \ell$ of $\mathrm{DO}$ per $1.0 \mathrm{mg} / \ell$ of $\mathrm{FeS}_{2}$.

38. Oxidation of sulfide can produce sulfur $(\mathrm{S})$, thiosulfate $\left(\mathrm{S}_{2} \mathrm{O}_{3}{ }^{-2}\right)$, sulfite $\left(\mathrm{SO}_{3}{ }^{-2}\right)$, or sulfate $\left(\mathrm{SO}_{4}{ }^{-2}\right)$ according to the following reactions (Chen and Morris 1972b):

$$
\begin{aligned}
& \mathrm{HS}^{-}+1 / 2 \mathrm{O}_{2}+\mathrm{H}^{+} \Rightarrow \mathrm{H}_{2} \mathrm{O}+\mathrm{S} \\
& 2 \mathrm{HS}^{-}+2 \mathrm{O}_{2}+\Rightarrow \mathrm{H}_{2} \mathrm{O}+\mathrm{s}_{2} \mathrm{O}_{3}^{-2}
\end{aligned}
$$




$$
\begin{aligned}
& \mathrm{HS}^{-}+3 / 2 \mathrm{O}_{2} \Rightarrow \mathrm{SO}_{3}^{-2}+\mathrm{H}^{+} \\
& \mathrm{HS}^{-}+2 \mathrm{O}_{2} \Rightarrow \mathrm{SO}_{4}^{-2}+\mathrm{H}^{+}
\end{aligned}
$$

The above reactions (i.e., Equations $14-17$ ) require $0.5,1.0,1.5$, and $2.0 \mathrm{mg} / \ell$ DO per $1.0 \mathrm{mg} / \ell \mathrm{s}^{-2}$, or $0.48,0.97,1.45$, and $1.94 \mathrm{mg} / \ell \mathrm{DO}$ per $1.0 \mathrm{mg} / \ell \mathrm{HS}^{-}$, respectively. Equation 16 is an intermediate step for sulfate production, where another half molecule of $\mathrm{O}_{2}$ is required to complete the reaction. However, the oxidation of sulfite to sulfate has been observed to occur slowly (O'Brien and Birkner 1977, Chen and Morris 1972b). Thiosulfate is considered a relatively stable oxidation product (0'Brien and Birkner 1977) that is slowly oxidized to sulfate with an observed half time of 8 days (Avrahami and Golding 1968). At low $\mathrm{pH}$, elemental sulfur has been observed as a precipitate (i.e., Equation 14), whereas for high $\mathrm{pH}$, thiosulfate (Equation 15) is the primary product (Chen and Morris 1972a). At neutral pH, a high ratio of sulfide to oxygen results in precipitation of sulfur, while a low ratio results in direct oxidation to thiosulfate (Chen and Morris 1972b).

39. A literature review by $0^{\prime}$ Brien and Birkner (1977) indicated that most experiments observed sulfite, thiosulfate, and sulfate as oxidation products of sulfide. They proposed the hypothetical reaction model

$$
4 \mathrm{HS}^{-}+51 / 2 \mathrm{O}_{2} \Rightarrow \mathrm{S}_{2} \mathrm{O}_{3}^{-2}+\mathrm{SO}_{3}^{-2}+\mathrm{SO}_{4}^{-2}+2 \mathrm{H}^{+}+\mathrm{H}_{2} \mathrm{O}
$$

This reaction requires $1.38 \mathrm{mg} / \ell \mathrm{O}_{2}$ per $1.0 \mathrm{mg} / \ell \mathrm{s}^{-2}$, or $1.33 \mathrm{mg} / \ell \mathrm{O}_{2}$ per $1.0 \mathrm{mg} / \ell \mathrm{HS}^{-}$. Experimental results of $0^{\prime}$ Brien and Birkner (1977) indicated an average stoichiometric value of $1.36 \mathrm{mg} / \ell \mathrm{O}_{2}$ per $1.0 \mathrm{mg} / \ell \mathrm{s}^{-2}$ at $\mathrm{pH}=7.55$. Respirometric studies by Chen and Morris (1972a) showed that about one molecule of oxygen was required per atom of sulfur oxidized, indicating a net oxidation primarily to thiosulfate for a $\mathrm{pH}$ range of 6.7 to 13.5 . In view of the variation in results and the complications of sulfide reactions, the value of $1.38 \mathrm{mg} / \ell \mathrm{O}_{2}$ per $1.0 \mathrm{mg} / \ell \mathrm{s}^{-2}$ is recommended to provide a reasonable yet conservative estimate of DO uptake requirements.

40. Ammonia can exist in un-ionized form, $\mathrm{NH}_{3}$, or in ionized form, $\mathrm{NH}_{4}^{+}$ (ammonium). Models usually consider total ammonia and do not distinguish the two forms. The distribution between ionized and un-ionized ammonia 
concentration varies with temperature and $\mathrm{pH}$, where un-ionized ammonia increases with temperature and $\mathrm{pH}$. However, un-ionized ammonia usually exists in small quantities in most natural waters. For example, for a $\mathrm{pH}$ of 8.0 and a temperature of $20.0^{\circ} \mathrm{C}$, less than 4.0 percent of the total ammonia is $\mathrm{NH}_{3}$ (Bowie et al. 1985).

41. Nitrifying bacteria convert ammonium $\left(\mathrm{NH}_{4}{ }^{+}\right)$to nitrate $\left(\mathrm{NO}_{3}{ }^{-}\right)$where the overall reaction is described as follows (Wetzel 1975)

$$
\mathrm{NH}_{4}^{+}+2 \mathrm{O}_{2} \Rightarrow \mathrm{NO}_{3}^{-}+\mathrm{H}_{2} \mathrm{O}+2 \mathrm{H}^{+}
$$

thus requiring $4.57 \mathrm{mg} / \ell \mathrm{O}_{2}$ per $1.0 \mathrm{mg} / \ell$ ammonium nitrogen (i.e., $\mathrm{NH}_{4}{ }^{+}$as $\mathrm{N}$ ). Nitrite $\left(\mathrm{NO}_{2}^{-}\right)$is an intermediate product that is highly labile to oxidation. Field studies of reservoir tailwaters (Nix et al. 1991) indicate that almost all of the loss in ammonia can be accounted for by nitrification to nitrate, i.e., loss in ammonia nitrogen approximately equaled gain in nitrate nitrogen with some loss of nitrate due to denitrification.

42. The rate of nitrification, or the oxidation of ammonium, can vary widely and is considered to be first-order dependent on ammonium concentration and dependent on temperature, DO, pH, and stream hydraulics, such as wetted perimeter and depth (Bowie et al. 1985). Measured nitrification rates between 0.1 and 0.5 day $^{-1}$ are typical for the deeper, larger water bodies, and rates greater than 1.0 day $^{-1}$ are not uncommon for shallow streams (Thomann and Mueller 1987). A temperature correction is usually used in the form of Equation 7 with a value of 1.08 for the base of the power term. Much work remains to be done before there exists a capability to predict the nitrification rate.

43. Nitrification is a source for nitrate nitrogen, and denitrification and algal uptake are sinks. Most stream water quality models, such as QUAL2E (Brown and Barnwell 1987), do not provide for denitrification when the stream is aerated (e.g., DO greater than about 0.5 to $2.0 \mathrm{mg} / \ell$ ). However, it is well established that denitrification can still occur in the bottom sediments of well-oxygenated streams, thus removing nitrate from the water column (Hill 1979). If proper representation of the nitrate balance is desired, then the model should include nitrification and denitrification, regardless of the DO concentration of the water column.

44. Sediment oxygen demand (SOD) can have a significant impact on DO in surface waters (Hatcher 1986). Benthic respirometers were used at several of 
the tailwater study sites in this research. SOD values of about 1.0 to 2.0 $\mathrm{g} / \mathrm{m}^{2} /$ day were measured in the Nimrod and Rough River tailwaters where the bed consisted predominantly of fine sediments (Nix et al. 1991). These rates exert an oxygen demand that is comparable to the demands caused by the oxidation of reduced substances and on the same order of magnitude as reaeration for sluggish streams. Therefore, SOD should be considered for a tailwater DO model.

45. Most surface waters experience oxygen uptake due to the decomposition of organic matter (i.e., organic carbon), in addition to the other oxygen sinks discussed above. There was an attempt to quantify this demand during the tailwater field studies of Nix et al. (1991). Standard, seeded 5-day biochemical oxygen demand (BOD) measurements indicated that BOD in the tailwaters ranged from 0.8 to greater than $7.0 \mathrm{mg} / \ell$. However, this measurement includes any nitrogen demand and/or chemical oxidation, such as oxidation of iron and iron sulfide. Therefore, these measurements were of little use for determining organic carbon oxygen demand.

46. Ten-day, unseeded BOD studies were also conducted where multiple bottles were analyzed at 1- to 2-day intervals for each sample location (Nix et al. 1991). During these studies, various constituents that can exert an oxygen demand (ammonium, iron, etc.) were measured, in addition to DO and total organic carbon (TOC). The hope was to stoichiometrically account for the various components of known oxygen demand and calculate the organic carbon demand by difference. Although there was a definite oxygen demand in each 10 day BOD study, the TOC did not show any trend, and the studies failed to reveal any definitive quantification of the organic carbon demand.

47. The QUAL2E model has carbonaceous BOD (i.e., CBOD) in it as a modeled state variable. This variable can be used to represent the organic carbon demand since the other oxygen demands will be accounted for directly through modeled state variables. The problem remains of how to estimate a value for $C B O D$ released from the reservoir that properly represents the organic carbon oxygen demand.

48. Reaeration is considered to be the primary source of DO in reservoir tailwaters fed by deep releases because production of oxygen through photosynthesis decreases with temperature, and deep releases tend to be cold. Additionally, deep releases tend to be void of phytoplankton. Light and dark bottle DO studies indicated that this is a good assumption (Nix et a1. 1991). Numerous stream reaeration models have been developed (Bowie et al. 1985), and 
most stream water quality models allow the user to select from a number of these models. Although this area of stream water quality modeling is well developed, there is still not a unified theory or equation to predict reaeration for a variety of stream conditions. It was beyond the scope of this research to investigate improved methods for modeling steam reaeration. Existing formulae are used for the model. 
49. A list of water quality constituents collected during the field studies of Nix et al. (1991) is provided in Table 1. The analyses discussed herein do not address each constituent but are limited to those of interest for the water quality model. Presently, the model focuses on DO, the variables that impact DO, and the most problematic substances (i.e., reduced iron, reduced manganese, and sulfide). Eventually, the model may be expanded to include other processes, such as $\mathrm{pH}$ dynamics, and the analysis of other data collected during the field studies may become necessary. The sections that follow in Part III describe analyses of field data to support development of the kinetic algorithms of the numerical model discussed in Part IV.

Table 1

Water Quality Constituents Measured

\title{
During Field Studies
}

\author{
Temperature \\ Dissolved oxygen \\ Specific conductance \\ $\mathrm{pH}$ \\ Free carbon dioxide \\ Alkalinity \\ Total organic carbon \\ Carbonaceous biochemical oxygen demand \\ Iron (total and dissolved) \\ Manganese (total and dissolved) \\ Sulfate \\ Sulfide \\ Nitrate-nitrogen \\ Ammonia-nitrogen \\ Total Kjeldahl nitrogen \\ Total phosphorus \\ Soluble reactive phosphorus \\ Chloride \\ Turbidity
}

\section{Reduced Manganese Removal}

50. Data taken from the four tailwater study sites (Nix et al. 1991; Appendix A) plus data from the earlier Greeson tailwater study (Nix 1986) and Duck River (Gordon 1989) were analyzed for dissolved manganese removal rate. 
A general equation to calculate the first-order removal rate $\left(\mathrm{K}_{\mathrm{Mn}}\right)$ for $\mathrm{Mn}^{+2}$ was developed based on stream characteristics. The procedure for development of an equation to predict $K_{m_{n}}$ was accomplished in several steps.

51. The first step was to determine the observed dissolved manganese loss rate $K_{\mathrm{Tn}}$ from the field data of dissolved manganese and travel time. The SAS procedure PROC REG (SAS Institute, Inc. 1988) was used to obtain the least squares best fit of the natural logarithm transform of the observed concentrations versus time. This regression equation form, which is shown in Equation 20, is the natural logarithm of Equation 1, where the slope of the line is $\mathrm{K}_{\mathrm{fn}}$, or

$$
\ln C=\ln C_{0}-K_{\operatorname{mn}} t
$$

where

$$
\begin{aligned}
\mathrm{C} & =\mathrm{Mn}^{+2} \text { observed at a downstream station with travel time, } t, \mathrm{mg} / \ell \\
\mathrm{C}_{\mathrm{o}} & =\text { initial (release) } \mathrm{Mn}^{+2} \text { concentration, } \mathrm{mg} / \mathrm{l} \\
\mathrm{K}_{\mathrm{Mn}} & =\mathrm{Mn}{ }^{+2} \text { loss rate for a specific field condition, } 1 / \text { day } \\
\mathrm{t} & =\text { travel time to station, days }
\end{aligned}
$$

The regression models developed from each observed data set to predict concentration of $\mathrm{Mn}^{+2}$ versus time (including regression coefficients, equation significance values, and correlation coefficients) are listed in Table 2 . The initial concentration $C_{o}$ was a free parameter to be estimated (i.e., the intercept of the regression). If the significance probability of the equation was greater than 0.05 , an estimated $K_{\mathbb{M n}_{n}}$ was not accepted. Thus, unacceptable $K_{\mathrm{In}}$ values were not used further in the determination of a general equation for $K_{\mathrm{Mn}}$. All the data sets (i.e., observed dissolved manganese concentration versus time) and the regression lines are plotted in Appendix C. It should be noted that the manganese data for Rough River were separated and analyzed as upper (i.e., the Falls of Rough pool caused by the mill dam) and lower (i.e., free-flowing stream) reaches since the data showed different slopes with a change in slope at the Falls of Rough Dam.

52. The next step was to try to relate the observed (through regres sion) $K_{\text {m n }}$ values to other variables, such as stream-average ambient water quality conditions. The initial approach used stepwise, multiple linear regression analysis (PROC STEPWISE, SAS Institute, Inc. 1988) to identify 
Table 2

Regression Results for $\mathrm{Mn}^{+2}$ Concentration Versus Time from Observed Data

\begin{tabular}{|c|c|c|c|c|c|}
\hline Location & $\begin{array}{l}\text { Data Set } \\
\text { Number* }\end{array}$ & $\begin{array}{c}\text { Independent } \\
\text { Variables } \\
\end{array}$ & $\begin{array}{c}\text { Regression } \\
\text { Coefficients } \\
\end{array}$ & $\begin{array}{c}\text { Equation } \\
\text { Significance } \\
\end{array}$ & $\mathrm{R}^{2}$ \\
\hline Duck River & 1 & $\begin{array}{l}\text { Intercept } \\
\text { Time }\end{array}$ & $\begin{array}{r}0.45 \\
-1.19\end{array}$ & 0.0001 & 0.98 \\
\hline Duck River & 2 & $\begin{array}{l}\text { Intercept } \\
\text { Time }\end{array}$ & $\begin{array}{r}0.44 \\
-1.65\end{array}$ & 0.0001 & 0.96 \\
\hline Duck River & 3 & $\begin{array}{l}\text { Intercept } \\
\text { Time }\end{array}$ & $\begin{array}{r}0.63 \\
-1.72\end{array}$ & 0.0001 & 0.96 \\
\hline $\begin{array}{l}\text { Little Missouri } \\
\text { River }\end{array}$ & 1 & $\begin{array}{l}\text { Intercept } \\
\text { Time }\end{array}$ & $\begin{array}{l}-1.38 \\
-0.87\end{array}$ & 0.2810 & 0.36 \\
\hline $\begin{array}{l}\text { Little Missouri } \\
\text { River }\end{array}$ & 2 & $\begin{array}{l}\text { Intercept } \\
\text { Time }\end{array}$ & $\begin{array}{l}-1.36 \\
-2.09\end{array}$ & 0.0177 & 0.79 \\
\hline $\begin{array}{l}\text { Little Missouri } \\
\text { River }\end{array}$ & 3 & $\begin{array}{l}\text { Intercept } \\
\text { Time }\end{array}$ & $\begin{array}{l}-1.35 \\
-2.34\end{array}$ & 0.0002 & 0.92 \\
\hline $\begin{array}{l}\text { Little Missouri } \\
\text { River }\end{array}$ & 4 & $\begin{array}{l}\text { Intercept } \\
\text { Time }\end{array}$ & $\begin{array}{l}-0.88 \\
-4.37\end{array}$ & 0.0002 & 0.95 \\
\hline $\begin{array}{l}\text { Little Missouri } \\
\text { River }\end{array}$ & 5 & $\begin{array}{l}\text { Intercept } \\
\text { Time }\end{array}$ & $\begin{array}{l}-1.13 \\
-2.27\end{array}$ & 0.0746 & 0.86 \\
\hline $\begin{array}{l}\text { Little Missouri } \\
\text { River }\end{array}$ & 6 & $\begin{array}{l}\text { Intercept } \\
\text { Time }\end{array}$ & $\begin{array}{l}-2.52 \\
-1.56\end{array}$ & 0.0007 & 0.92 \\
\hline $\begin{array}{l}\text { Little Missouri } \\
\text { River }\end{array}$ & 7 & $\begin{array}{l}\text { Intercept } \\
\text { Time }\end{array}$ & $\begin{array}{l}-2.43 \\
-2.89\end{array}$ & 0.0001 & 0.97 \\
\hline $\begin{array}{l}\text { Little Missouri } \\
\text { River }\end{array}$ & 8 & $\begin{array}{l}\text { Intercept } \\
\text { Time }\end{array}$ & $\begin{array}{l}-1.67 \\
-3.94\end{array}$ & 0.0051 & 0.94 \\
\hline $\begin{array}{l}\text { Little Missouri } \\
\text { River }\end{array}$ & 9 & $\begin{array}{l}\text { Intercept } \\
\text { Time }\end{array}$ & $\begin{array}{l}-1.76 \\
-4.18\end{array}$ & 0.0146 & 0.97 \\
\hline $\begin{array}{l}\text { Fourche La Fave } \\
\text { River }\end{array}$ & 1 & $\begin{array}{l}\text { Intercept } \\
\text { Time }\end{array}$ & $\begin{array}{r}1.05 \\
-1.52\end{array}$ & 0.0014 & 0.94 \\
\hline $\begin{array}{l}\text { Fourche La Fave } \\
\text { River }\end{array}$ & 2 & $\begin{array}{l}\text { Intercept } \\
\text { Time }\end{array}$ & $\begin{array}{r}0.82 \\
-0.70\end{array}$ & 0.1136 & 0.79 \\
\hline
\end{tabular}

* The data set number is shown on the plots in Figure C1. 


\begin{tabular}{|c|c|c|c|c|c|}
\hline Location & $\begin{array}{l}\text { Data Set } \\
\text { Number* }\end{array}$ & $\begin{array}{l}\text { Independent } \\
\text { Variables } \\
\end{array}$ & $\begin{array}{c}\text { Regression } \\
\text { Coefficients } \\
\end{array}$ & $\begin{array}{c}\text { Equation } \\
\text { Significance } \\
\end{array}$ & $\mathrm{R}^{2}$ \\
\hline $\begin{array}{l}\text { Fourche La Fave } \\
\text { River }\end{array}$ & 3 & $\begin{array}{l}\text { Intercept } \\
\text { Time }\end{array}$ & $\begin{array}{r}1.21 \\
-0.71\end{array}$ & 0.0001 & 0.99 \\
\hline $\begin{array}{l}\text { Fourche La Fave } \\
\text { River }\end{array}$ & 4 & $\begin{array}{l}\text { Intercept } \\
\text { Time }\end{array}$ & $\begin{array}{r}0.12 \\
-1.79\end{array}$ & 0.0001 & 0.99 \\
\hline $\begin{array}{l}\text { Fourche La Fave } \\
\text { River }\end{array}$ & 5 & $\begin{array}{l}\text { Intercept } \\
\text { Time }\end{array}$ & $\begin{array}{r}0.21 \\
-1.81\end{array}$ & 0.0004 & 0.97 \\
\hline $\begin{array}{l}\text { Rough River } \\
\text { (upper) }\end{array}$ & 1 & $\begin{array}{l}\text { Intercept } \\
\text { Time }\end{array}$ & $\begin{array}{r}0.75 \\
-0.05\end{array}$ & 0.0855 & 0.56 \\
\hline $\begin{array}{l}\text { Rough River } \\
\text { (lower) }\end{array}$ & 2 & $\begin{array}{c}\text { Intercept } \\
\text { Time }\end{array}$ & $\begin{array}{r}0.60 \\
-0.30\end{array}$ & 0.2178 & 0.89 \\
\hline $\begin{array}{l}\text { Rough River } \\
\text { (upper) }\end{array}$ & 3 & $\begin{array}{l}\text { Intercept } \\
\text { Time }\end{array}$ & $\begin{array}{r}0.72 \\
-0.03\end{array}$ & 0.1801 & 0.40 \\
\hline $\begin{array}{l}\text { Rough River } \\
\text { (lower) }\end{array}$ & 4 & $\begin{array}{l}\text { Intercept } \\
\text { Time }\end{array}$ & $\begin{array}{r}0.67 \\
-0.43\end{array}$ & 0.0142 & 0.99 \\
\hline $\begin{array}{l}\text { Guadalupe River } \\
\text { (Canyon) }\end{array}$ & & $\begin{array}{l}\text { Intercept } \\
\text { Time }\end{array}$ & $\begin{array}{l}-2.08 \\
-4.45\end{array}$ & 0.0066 & 0.87 \\
\hline
\end{tabular}

independent variables that were the best predictors of $\mathrm{K}_{\mathrm{mn}}$. Many of the variables tested (i.e., $\mathrm{pH},[\mathrm{DO}],\left[\mathrm{OH}^{-}\right],\left[\mathrm{C}_{0}\right]$, temperature, etc.) have been cited by other researchers as affecting manganese oxidation (Stumm and Morgan 1981, Hess 1984, Hsiung 1987). Table 3 lists the variables and combinations of variables tested using PROC STEPWISE. Average values for the tailwater reach were used for each variable in Table 3. Hess' equation (Equation 4) was the first equation examined since it had been used to describe manganese oxidation in tailwaters. However, the Hess equation produced unrealistic relationships (i.e., negative coefficients) for some of the independent variables, thus incorrectly describing the processes. As a result, variations of this equation and many others were examined to try to explain the mechanisms driving the oxidation and loss of $\mathrm{Mn}^{+2}$. As with the Hess equation, unrealistic relationships were obtained for many of the independent variables examined in the other equation forms. The PROC STEPWISE analysis did not produce an equation that adequately described the rate coefficients for $\mathrm{Mn}^{+2}$ removal. 
Table 3

Variables Tested in $K_{m}$ Regression Analysis

\begin{tabular}{|c|c|}
\hline Variable & $\begin{array}{c}\text { Variable Description } \\
\end{array}$ \\
\hline$\left[\mathrm{OH}^{-}\right]^{2}$ & Hydroxide ion concentration squared \\
\hline$\left[\mathrm{H}^{+}\right]^{2}$ & Hydrogen ion concentration squared \\
\hline$\left[\mathrm{C}_{\mathrm{o}}\right]$ & Initial $\mathrm{Mn}^{+2}$ concentration, moles $/ \ell$ \\
\hline Ratio & Top width (W) over hydraulic depth $(H)$, ft/ft \\
\hline [DO $]$ & Dissolved oxygen concentration, moles/l \\
\hline $\mathrm{P}_{0}$ & Partial pressure of oxygen, atm \\
\hline $1 / \mathrm{H}$ & Inverse of hydraulic depth $(H), 1 / f t$ \\
\hline $\mathrm{u}_{\star} / \mathrm{H}$ & Ratio of shear velocity $\left(u_{*}\right)$ to $H, 1 / \mathrm{sec}$ \\
\hline$\left[\mathrm{C}_{\mathrm{o}}\right] / \mathrm{H}$ & Ratio of $\left[\mathrm{C}_{\mathrm{o}}\right]$ to $\mathrm{H}$, moles/l-ft \\
\hline COMB1 & Combination of $\left[\mathrm{OH}^{-}\right]^{2} *$ Ratio*Co \\
\hline СОМB2 & Combination of $\left[\mathrm{OH}^{-}\right]^{2} *$ Ratio $* \mathrm{C}_{\circ} *[\mathrm{DO}]$ \\
\hline СOMB3 & Combination of $\left[\mathrm{OH}^{-}\right]^{2} *[\mathrm{DO}]$ \\
\hline COMB4 & Combination of Ratio $* \mathrm{C}_{0}$ \\
\hline COMB5 & Combination of $\left[\mathrm{OH}^{-}\right]^{2} \times \mathrm{P}_{0}$ \\
\hline COMB6 & Combination of $\left[\mathrm{OH}^{-}\right]^{2} *[\mathrm{DO}] * \mathrm{C}_{\mathrm{o}}$ \\
\hline COMB7 & Combination of $\left[\mathrm{OH}^{-}\right]^{2} * \mathrm{C}$ 。 \\
\hline COMB8 & Combination of $\left[\mathrm{C}_{\mathrm{o}}\right][\mathrm{DO}]$ \\
\hline $\mathrm{COMB} 7 / \mathrm{H}$ & Ratio of $\left[\mathrm{OH}^{-}\right]^{2} * \mathrm{C}_{0}$ to $\mathrm{H}$ \\
\hline COMB6/H & Ratio of $\left[\mathrm{OH}^{-}\right]^{2} *[\mathrm{DO}] * \mathrm{C}_{0}$ to $\mathrm{H}$ \\
\hline COMB8 $/\left[\mathrm{H}^{+}\right]^{2}$ & Ratio of $\left[\mathrm{C}_{\mathrm{o}}\right][\mathrm{DO}]$ to $\left[\mathrm{H}^{+}\right]^{2}$ \\
\hline$\left[\mathrm{C}_{\mathrm{o}}\right] /\left[\mathrm{H}^{+}\right]^{2}$ & Ratio of $\left[\mathrm{C}_{\mathrm{o}}\right]$ to $\left[\mathrm{H}^{+}\right]^{2}$ \\
\hline $1 /\left[\mathrm{H}^{+}\right]^{2}$ & Inverse of $\left[\mathrm{H}^{+}\right]^{2}$ \\
\hline
\end{tabular}

Note: All variables are averages for the tailwater reach.

53. As discussed in Part II, many researchers suggest that the primary removal mechanism for dissolved manganese is adsorption which occurs rapidly, followed by slow oxidation on particulates or the substrate. If adsorption onto the substrate is a primary removal mechanism for dissolved manganese, it makes sense that variables describing the rate of oxidation would have little meaning in explaining the observed loss rate. Consider the mass balance of dissolved manganese in a control volume of fixed volume $V$ and bottom planar area $A$. The rate of decrease in dissolved manganese through adsorption onto the bottom can be described by 


$$
V \frac{d M n}{d t}=-V_{s} A\left(M n-M n_{b}\right)
$$

where

$$
\begin{aligned}
\mathrm{Mn}= & \text { dissolved }(\mathrm{i} . \mathrm{e} ., \text { reduced) manganese concentration, } \mathrm{mg} / \mathrm{l} \\
\mathrm{V}_{\mathrm{s}}= & \text { mass transfer velocity across diffusive sublayer separating } \\
& \text { water and substrate, } \mathrm{L} / \mathrm{T} \\
\mathrm{Mn}_{\mathrm{b}}= & \text { reduced manganese concentration in sediment pore water, } \mathrm{mg} / \ell
\end{aligned}
$$

Assuming that the manganese in the pore water is rapidly adsorbed onto sediment particles, $\mathrm{Mn}_{\mathrm{b}}$ can be assumed to be insignificant, and Equation 21 becomes

$$
\frac{d M n}{d t}=-\frac{V_{s}}{H} M n
$$

where $\mathrm{H}$ is the hydraulic depth, i.e., V/A.

54. Equation 22 looks like Equation 1 where the loss rate $K_{M_{n}}$ is $\mathrm{V}_{\mathrm{s}} / \mathrm{H}$. This reasoning helps to explain why observed data indicate that dissolved manganese is rapidly removed in streams according to a first-order rate law. From the PROC STEPWISE regressions, $1 / \mathrm{H}$ was found to be the most significant independent variable, having a coefficient of determination (i.e., $\mathrm{R}^{2}$ ) of 0.62 , or accounting for 62 percent of the variation in the dependent variable.

55. The next step was to find a way to estimate $V_{s}$. This led to an approach based on the results published by Boudreau and Guinasso (1982) that relate the mass transfer of dissolved substances across the diffusive sublayer of the ocean bed. Several relationships from Boudreau and Guinasso (1982) were used to compute $V_{s}$. These computed $V_{s}$ values for each equation were graphically compared with measured (i.e., based on observed manganese data) $\mathrm{V}_{s}$ values, which were calculated from $\mathrm{V}_{\mathrm{s}}-\mathrm{K}_{\mathrm{m}} \mathrm{H}$, where $\mathrm{K}_{\mathrm{m}}$ values were taken from the slope of the manganese versus time regressions (Table 2).

56. All of the relationships from Boudreau and Guinasso (1982) require water viscosity $\nu$ and molecular diffusivity of the solute $D$ for computing $\mathrm{V}_{\mathrm{s}}$. Therefore, $\mathrm{V}_{\mathrm{s}}$ values were computed using values of $\nu$ and $\mathrm{D}$ corresponding to the observed average stream temperature, $T$. The value for $D_{T}$ (i.e., at temperature T ) can be computed (Thibodeaux 1979) from 


$$
\mathrm{D}_{\mathrm{T}}=\mathrm{D}_{25} \frac{\mathrm{T} \nu_{25}}{25 \nu_{\mathrm{T}}}
$$

where

$$
\begin{aligned}
\mathrm{D}_{\mathrm{T}}= & \text { molecular diffusion coefficient of } \mathrm{Mn}^{+2} \text { at stream temperature } \mathrm{T}, \\
& \mathrm{cm}^{2} / \mathrm{sec} \\
\mathrm{D}_{25}= & \text { molecular diffusion coefficient of } \mathrm{Mn}^{+2} \text { at } 25^{\circ} \mathrm{C}, 6.88 \\
& \times 10^{-6} \mathrm{~cm}^{2} / \mathrm{sec} \\
\mathrm{T}= & \text { ambient stream temperature, }{ }^{\circ} \mathrm{C} \\
\nu_{25}= & \text { kinematic viscosity of water at } 25^{\circ} \mathrm{C}, 0.93 \times 10^{-6} \mathrm{~cm}^{2} / \mathrm{sec} \\
\nu_{\mathrm{T}}= & \text { kinematic viscosity at stream temperature } \mathrm{T}, \mathrm{cm}^{2} / \mathrm{sec}
\end{aligned}
$$

A regression for viscosity $\left(\nu_{\mathrm{T}}\right)$ versus temperature was developed from tabulated values, resulting in

$$
\nu_{\mathrm{T}}=0.000001674-3.061667 \times 10^{-8} \mathrm{~T}
$$

57. The following equation was chosen to calculate (i.e., predict) $V_{s}$ since its absolute mean error (i.e., mean |predicted - measured|) was less than the absolute mean error of the other relationships in Boudreau and Guinasso (1982):

$$
\mathrm{V}_{\mathrm{s}}=\frac{\mathrm{Du} \cdot \mathrm{Sc}^{1 / 3}}{24 \nu}
$$

where

$$
\begin{aligned}
u_{*} & =\text { shear velocity }(\sqrt{\mathrm{gHs}}), \mathrm{L} / \mathrm{T} \\
\mathrm{g} & =\text { gravitational acceleration, } L / T^{2} \\
\mathrm{~s} & =\text { water surface or streambed slope, nondimensional } \\
\mathrm{Sc} & =\text { Schmidt Number }(\nu / D), \text { nondimensional }
\end{aligned}
$$

and values for $D$ and $\nu$ are taken at ambient stream temperature $T$.

58. Graphs of predicted versus measured $V_{s}$ indicated that the data could be divided into two groups, one representing cobble bed streams and the other representing sediment (i.e., fine grain, silt and clay) bed streams. A two-tailed mean analysis was performed on both groups to see if there was enough difference between the mean $V_{s}$ for each group to justify having 
separate equations for $V_{s}$ for the two streambed types. To perform the twotailed mean analysis, the assumption had to be verified that the variances of $\mathrm{V}_{\mathrm{s}}$ for the two streambed types were equal. This assumption was verified using the $F$ test analysis at the significance level of $\alpha=0.02$. Upon verification that the variances were equal, the two-tailed mean analysis was tested at a significance level of $\alpha=0.05$. It was concluded from the analysis that the mean $V_{s}$ values for the two streambed types were different enough to develop separate equations for $V_{s}$. It is not known how a sandy substrate would impact the manganese removal rate since none of the tailwaters studied here had significant quantities of sandy material.

59. Linear regression analysis with PROC REG (SAS Institute, Inc. 1988) was used to relate the measured and computed (i.e., computed with Equation 25) $\mathrm{V}_{\mathrm{s}}$ values for both streambed types, or

$$
\mathrm{V}_{\mathrm{s}_{\mathrm{m}}}=\mathrm{a} \mathrm{V}_{\mathrm{s}_{\mathrm{c}}}
$$

where

$$
\begin{aligned}
\mathrm{V}_{\mathrm{s}_{\mathrm{m}}} & =\text { measured mass transfer rate, } \mathrm{L} / \mathrm{T} \\
\mathrm{a} & =\text { regression coefficient, dimensionless } \\
\mathrm{V}_{\mathrm{s}_{\mathrm{c}}} & =\text { mass transfer coefficient computed with Equation } 25, \mathrm{~L} / \mathrm{T}
\end{aligned}
$$

Figure 1 shows the regression lines fitting the computed versus measured $V_{s}$ for the cobble and sediment streambed types, respectively. Regression coefficients, significance value, and $\mathrm{R}^{2}$ for the Equation 26 model are 1 isted in Table 4 for both streambed types. It is reasonable that the cobble bed regression results in larger values for $V_{s}$ since larger roughness elements associated with cobbles would tend to increase turbulence, thus increasing the diffusive sublayer mass transfer velocity.

60. The general method to predict $K_{M_{n}}$ can be summarized as follows. Equations 23 and 24 are first used to obtain $D$ and $\nu$ for the ambient water temperature. Next, $V_{s}$ is estimated with Equation 25 using the previously corrected values for $D$ and $\nu$ and the stream hydraulics to obtain $u_{*}$. Equation 26 is used to obtain an improved estimate for $V_{s}$ using the value computed by Equation 25. Finally, the result obtained with Equation 26 is divided by $\mathrm{H}$ to obtain $\mathrm{K}_{\mathrm{Mn}}$. A plot of predicted versus observed $\mathrm{K}_{\mathrm{Mn}}$ using this methodology is shown in Figure 2. The line in Figure 2 is the 


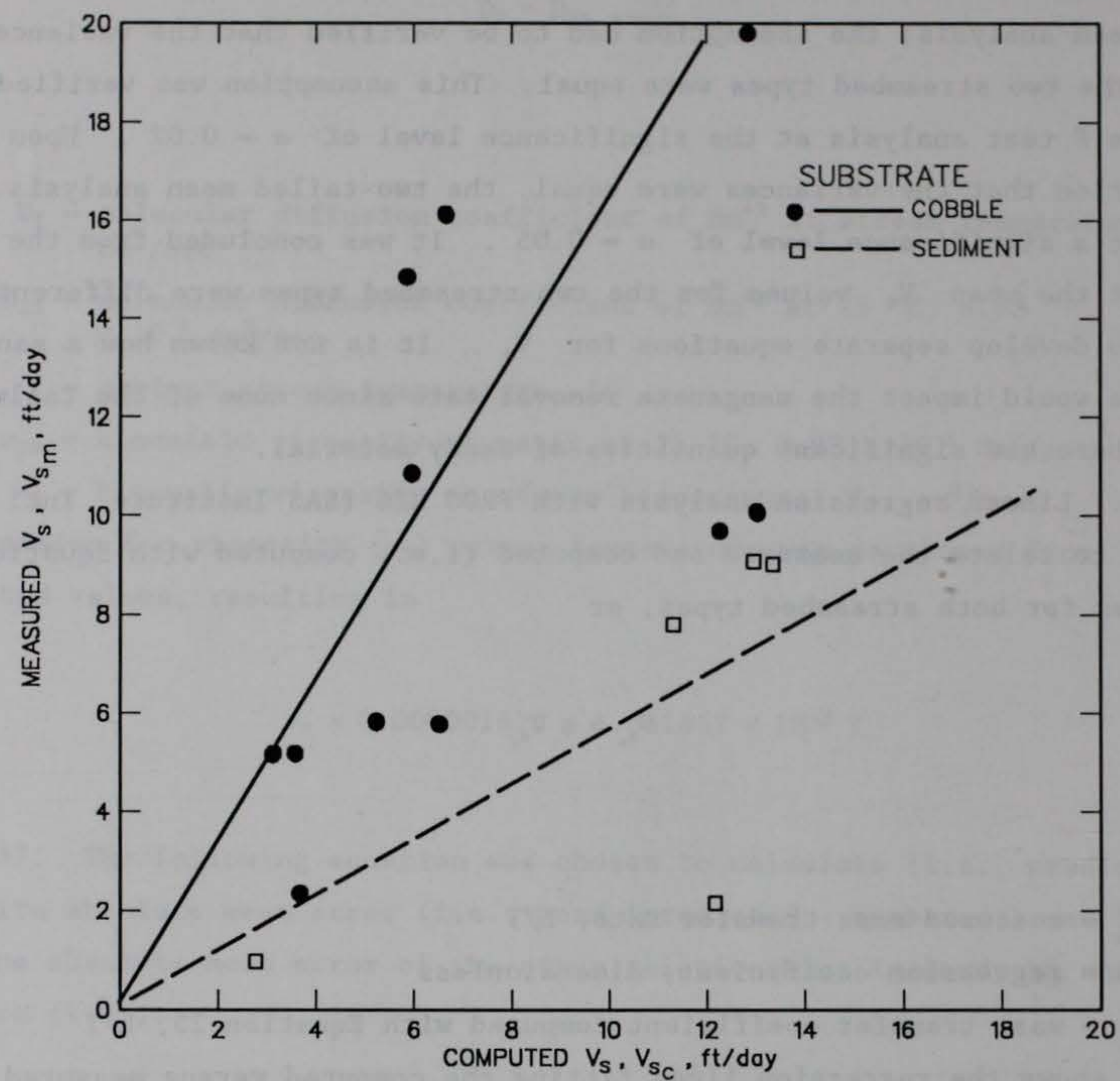

Figure 1. Measured versus computed $V_{s}$ for Mn data divided into cobble and sediment substrates

Table 4

Regression Results for Equation 26

\begin{tabular}{|c|c|c|c|c|}
\hline $\begin{array}{c}\text { Streambed } \\
\text { Type }\end{array}$ & $\begin{array}{l}\text { Independent } \\
\text { Variable } \\
\end{array}$ & $\begin{array}{c}\text { Regression } \\
\text { Coefficients } \\
\end{array}$ & $\begin{array}{c}\text { Equation } \\
\text { Significance }\end{array}$ & $\mathrm{R}^{2}$ \\
\hline Cobble & $\mathrm{v}_{\mathrm{s}}$ & 1.654 & 0.0001 & 0.89 \\
\hline Sediment & $\mathrm{v}_{\mathrm{s}}$ & 0.579 & 0.0057 & 0.88 \\
\hline
\end{tabular}




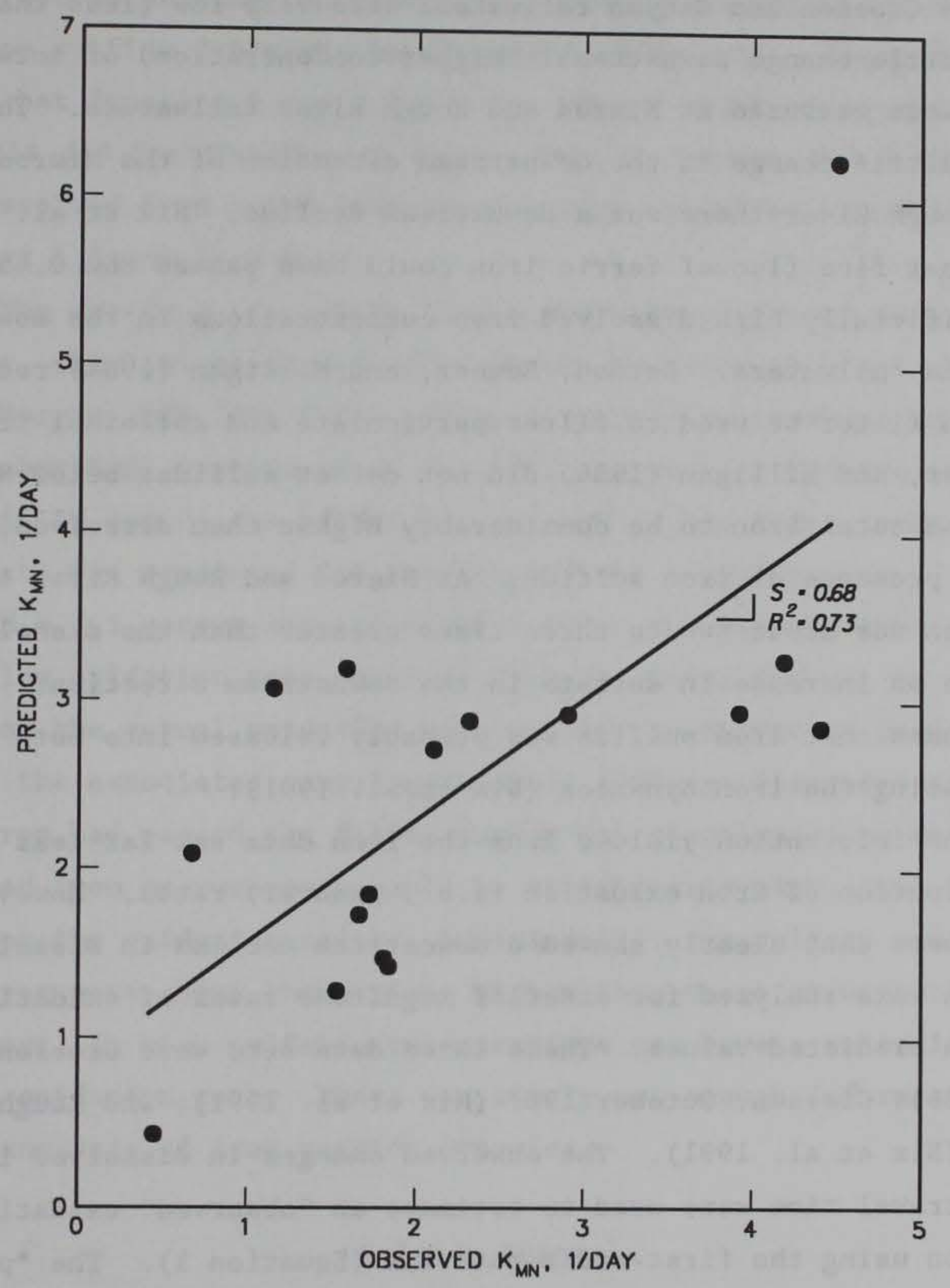

Figure 2. Predicted versus observed dissolved manganese removal rate, $\mathrm{K}_{\mathrm{Mn}}$

least squares best fit. The slope of this line is .68 and has an $R^{2}$ value of 0.74. The regression slope is not significantly different $(\alpha=0.05)$ from a perfect correlation slope of 1.0 .

\section{Reduced Iron Removal}

61. It was difficult to interpret the reduced iron data taken at the four study sites. Reduced iron, i.e., ferrous iron, was defined as dissolved 
iron, or the iron that passed through a $0.45-\mu$ filter. The dissolved iron data from the Greeson and Canyon tailwaters were very low (less than $0.1 \mathrm{mg} / \ell$ ) and showed little change downstream. Higher concentrations of total and dissolved iron were measured at Nimrod and Rough River tailwaters. The dissolved iron showed little change in the downstream direction of the Nimrod tailwater, whereas at Rough River there was a downstream decline. Nix et al. (1991) speculated that fine floc of ferric iron could have passed the $0.45-\mu$ filter, yielding artificially high dissolved iron concentrations in the downstream reaches of the tailwaters. Gordon, Bonner, and Milligan (1984) recommended that a $0.10-\mu$ filter be used to filter particulate and colloidal iron. Gordon, Bonner, and Milligan (1984) did not detect sulfides below Normandy Dam, but found total iron to be considerably higher than dissolved, indicating the possible presence of iron sulfide. At Nimrod and Rough River tailwaters, the total iron was about two to three times greater than the dissolved iron, and there was an increase in sulfate in the downstream direction. Therefore, it was concluded that iron sulfide was probably released into both tailwaters, thus complicating the iron dynamics (Nix et al. 1991).

62. The information yielded from the iron data was far less than desirable for evaluation of iron oxidation (i.e., removal) rates. However, three of the data sets that clearly showed a downstream decline in dissolved iron concentration were analyzed for order of magnitude rates of oxidation and were compared with predicted values. These three data sets were Greeson, September 1983 (Nix 1986); Greeson, October 1987 (Nix et al. 1991); and Rough River, August 1988 (Nix et al. 1991). The observed changes in dissolved iron concentration and travel time were used to estimate an "observed" oxidation rate of dissolved iron using the first-order rate law (Equation 1). The "predicted" oxidation rate at $20^{\circ} \mathrm{C}$ was computed with Equation 6 using the average DO and $\mathrm{pH}$ observed throughout the tailwater reach from which the "observed" oxidation rate was estimated. The predicted rates were then corrected for the temperature observed in the reach using Equation 7.

63. The following results were obtained for the three data sets:

\begin{tabular}{|c|c|c|c|}
\hline Study & Date & $\begin{array}{c}\text { Observed } \\
\text { day }^{-1}\end{array}$ & $\begin{array}{c}\text { Predicted } \mathrm{K}_{\mathrm{Fe}} \\
\text { day }^{-1}\end{array}$ \\
\hline Greeson & Sep 1983 & 0.54 & 0.12 \\
\hline Greeson & Oct 1987 & 6.65 & 1.16 \\
\hline Rough River & Aug 1988 & 1.25 & 150. \\
\hline
\end{tabular}


The fact that the predicted rates of iron oxidation do not agree with those observed is not surprising considering the complex interactions surrounding iron and iron sulfide dynamics, as discussed in Part II. These results at least show that Equation 6 can provide the proper order of magnitude estimate for $\mathrm{K}_{\mathrm{Fe}}$, as it did for the Greeson site. Gordon, Bonner, and Milligan (1984) measured dissolved iron below Normandy Dam that exhibited removal rates between about 1.8 and 18.0 day $^{-1}$.

64. The observed rates were higher than the predicted rates at the Greeson site, which might be explained by the presence of other trace metals (Stumm and Morgan 1981, Nix 1986). Higher rates were observed and predicted for the October 1987 Greeson study than for the earlier Greeson study; this may be partially due to the higher $\mathrm{pH}$ observed in the later study. A high oxidation rate was predicted for the Rough River study because of much higher $\mathrm{pH}$ (i.e., $\mathrm{pH}=7.5$ versus about 5.6 and 6.2 for the Greeson studies). The relatively low oxidation rate observed at Rough River may not be a true indication of the actual oxidation rate due to the suspected presence of iron sulfide and the associated sampling/analysis problems discussed above. If colloidal iron had passed the filter during the dissolved iron measurements, the dissolved iron measurements would be artificially high, thus lowering estimates for the oxidation rates. Additionally, the sulfate concentrations at Rough River were about three times higher than those at Greeson. As mentioned in Part II, high sulfate concentrations can have a retarding influence on the iron oxidation rate. There was simply not enough information to allow definitive analysis of iron sulfide dynamics.

\section{$\underline{\text { Sulfide Removal }}$}

65. Very little information could be extracted from the field studies for sulfide removal. Sulfide was detected in small quantities at Greeson tailwater in 1983 (Nix 1986), Nimrod tailwater in 1989 (Appendix A), and Canyon tailwater in 1988 ( $\mathrm{Nix}$ et al. 1991). Analyses of these three data sets are discussed below.

66. The 1983 Greeson data indicate that sulfide decreased from about $0.3 \mathrm{mg} / \ell$ to $0.04 \mathrm{mg} / \ell$ over the first $10 \mathrm{~km}$ of the tailwater. The travel time for this reach and flow rate reported by $\mathrm{Nix}$ (1986) are now considered to be in error; the correct travel time is approximately $3.8 \mathrm{hr}$. This decrease in sulfide over $3.8 \mathrm{hr}$ translates into a loss rate of about 12.7 day $^{-1}$. The pH 
during this study was approximately 5.5, which means that most (i.e., about 95 percent) of the sulfide existed as $\mathrm{H}_{2} \mathrm{~S}$ and was lost by volatilization. A hydrogen sulfide volatilization rate of 12.7 day $^{-1}$ is of the same order of magnitude as the reaeration rate of about 7.0 day $^{-1}$ that was measured (Dortch and Hamlin 1988). Recall from Part II that the reaeration rate can be used to estimate the hydrogen sulfide volatilization rate.

67. Sulfide was found to decrease at Nimrod in 1989 from about $0.017 \mathrm{mg} / \ell$ just below the dam to about $0.012 \mathrm{mg} / \ell$ at the next downstream sampling station, which is about $1.8 \mathrm{hr}$ travel time at the high-flow discharge. About 75 percent of the measured sulfide was $\mathrm{H}_{2} \mathrm{~S}$ for the observed $\mathrm{pH}$ of 6.5 . Therefore, HS ${ }^{-}$decreased from 0.0043 to about $0.0030 \mathrm{mg} / \ell$. This decrease results in an overall sulfide oxidation rate of about 4.6 day $^{-1}$. Correcting for DO and temperature (see Equations 8 and 9 , respectively) provides an estimated $k_{s}$ in Equation 8 of about 4.9 day $^{-1}$ at $20{ }^{\circ} \mathrm{C}$. This rate is on the low side of the range of reported rates discussed in Part II.

68. Nix et al. (1991) reported that the sulfide at Canyon tailwater decreased from about $0.04 \mathrm{mg} / \ell$ just below the dam to background levels at the next downstream station. The travel time to the first station was $70 \mathrm{~min}$. Based on the data, it was assumed that background levels were about $0.01 \mathrm{mg} / \ell$. For the observed $\mathrm{pH}$ of $7.6,80$ percent of the sulfide is $\mathrm{HS}^{-}$. This translates into an overall oxidation rate for $\mathrm{HS}^{-}$of about $24.0 \mathrm{day}^{-1}$. Correcting for temperature and DO as above, $k_{s}$ at $20{ }^{\circ} \mathrm{C}$ is 36.7 day $^{-1}$. This value falls about in the middle of the reported ranges.

\section{Nitrification}

69. The ammonia data reported by Nix et al. (1991) were analyzed in a manner similar to the manganese data. Ten data sets (Table 5) that clearly showed a downstream decrease in ammonia were used in the analysis. Linear regressions were developed for the natural $\log$ of the ammonia concentrations versus travel time so that the overall ammonium loss (i.e., nitrification rate $\mathrm{K}_{\mathrm{a}}$, day ${ }^{-1}$ ) could be determined from the slope of the regression. Plots of the data and the regression lines are presented in Appendix $C$. The $K_{a}$ value obtained from the regressions (i.e., measured $K_{a}$ ), the correlation coefficient, and significance of the regression are shown in Table 5. Data were excluded from further analysis if the significance probability of the equation was greater than 0.05 . Separation of the ammonia data into upper and lower 
Table 5

Regression Results for $\mathrm{NH}^{+}$Concentration Versus Time from Measured Data

\begin{tabular}{|c|c|c|c|c|c|}
\hline Location & $\begin{array}{l}\text { Data Set } \\
\text { Number* }\end{array}$ & $\begin{array}{c}\text { Independent } \\
\text { Variables }\end{array}$ & $\begin{array}{c}\text { Regression } \\
\text { Coefficients } \\
\end{array}$ & $\begin{array}{c}\text { Equation } \\
\text { Significance }\end{array}$ & $\mathrm{R}^{2}$ \\
\hline $\begin{array}{l}\text { Little Missouri } \\
\text { River }\end{array}$ & & $\begin{array}{l}\text { Intercept } \\
\text { Time }\end{array}$ & $\begin{array}{l}-2.69 \\
-4.33\end{array}$ & 0.2194 & 0.61 \\
\hline $\begin{array}{l}\text { Fourche La Fave } \\
\text { River }\end{array}$ & 1 & $\begin{array}{l}\text { Intercept } \\
\text { Time }\end{array}$ & $\begin{array}{l}-0.46 \\
-1.35\end{array}$ & 0.0007 & 0.96 \\
\hline $\begin{array}{l}\text { Fourche La Fave } \\
\text { River }\end{array}$ & 2 & $\begin{array}{l}\text { Intercept } \\
\text { Time }\end{array}$ & $\begin{array}{l}-0.86 \\
-0.77\end{array}$ & 0.1587 & 0.71 \\
\hline $\begin{array}{l}\text { Fourche La Fave } \\
\text { River }\end{array}$ & 3 & $\begin{array}{l}\text { Intercept } \\
\text { Time }\end{array}$ & $\begin{array}{l}-0.57 \\
-0.66\end{array}$ & 0.0097 & 0.92 \\
\hline $\begin{array}{l}\text { Fourche La Fave } \\
\text { River }\end{array}$ & 4 & $\begin{array}{l}\text { Intercept } \\
\text { Time }\end{array}$ & $\begin{array}{l}-1.32 \\
-1.79\end{array}$ & 0.0001 & 0.99 \\
\hline $\begin{array}{l}\text { Fourche La Fave } \\
\text { River }\end{array}$ & 5 & $\begin{array}{l}\text { Intercept } \\
\text { Time }\end{array}$ & $\begin{array}{l}-1.25 \\
-1.32\end{array}$ & 0.0007 & 0.96 \\
\hline Rough River & 1 & $\begin{array}{l}\text { Intercept } \\
\text { Time }\end{array}$ & $\begin{array}{r}0.13 \\
-0.84\end{array}$ & 0.0029 & 0.74 \\
\hline Rough River & 2 & $\begin{array}{l}\text { Intercept } \\
\text { Time }\end{array}$ & $\begin{array}{r}0.08 \\
-0.13\end{array}$ & 0.0116 & 0.62 \\
\hline Rough River & 3 & $\begin{array}{l}\text { Intercept } \\
\text { Time }\end{array}$ & $\begin{array}{r}0.09 \\
-0.15\end{array}$ & 0.0012 & 0.80 \\
\hline Guadalupe River & & $\begin{array}{c}\text { Intercept } \\
\text { Time }\end{array}$ & $\begin{array}{l}-2.18 \\
-2.39\end{array}$ & 0.0003 & 0.90 \\
\hline
\end{tabular}

* The data set number is shown on the plots in Figure C2.

reaches for Rough River resulted in insignificant regression; thus, the ammonia data were not separated.

70. As discussed in Part II, nitrification is considered to be affected by stream hydraulics, i.e., contact with the substrate. Therefore, the methods outlined earlier for computing the diffusive sublayer mass transfer velocity $V_{s}$ were used here, with the exception that $D_{20}$ for ammonia is 1.76 $\times 10^{-5} \mathrm{~cm}^{2} / \mathrm{sec}$, and a reference temperature of $20^{\circ} \mathrm{C}$ rather than $25{ }^{\circ} \mathrm{C}$ is used in Equation 23. The quantity $\mathrm{V}_{\mathrm{s}} / \mathrm{H}$ was correlated with the measured $\mathrm{K}_{\mathrm{a}}$, yielding a regression coefficient of 0.136 with an $R^{2}$ value of 0.83 and a 
significance of 0.0006 . Thus, ammonia is modeled with a first-order removal, with the removal (nitrification) rate prescribed by

$$
\mathrm{K}_{\mathrm{a}}=0.136 \frac{\mathrm{V}_{\mathrm{s}}}{\mathrm{H}}
$$

71. A plot of predicted (with Equations 23-25 and 27) versus observed $\mathrm{K}_{\mathrm{a}}$ is shown in Figure 3 . The slope of the least squares best fit regression line shown in Figure 3 is 0.65 and has an $R^{2}$ value of 0.77 . This slope is not significantly different $(\alpha=0.05)$ from the perfect correlation slope of 1.0. A temperature correction was applied to $K_{a}$ with an equation of the same form as Equation 7 and a value of 1.08 for the base of the power term. 


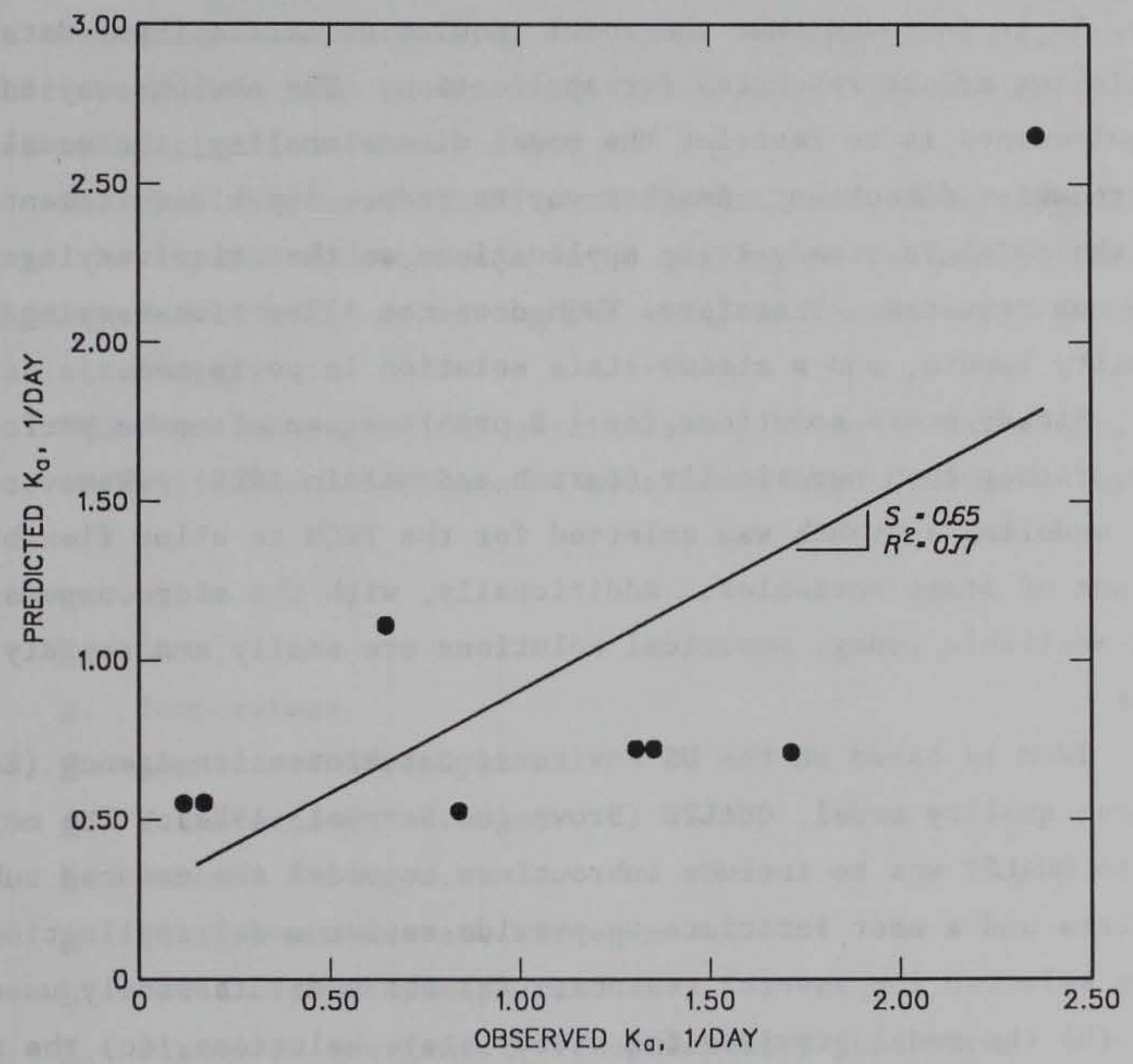

Figure 3. Predicted versus observed ammonia-N removal rate, $\mathrm{K}_{\mathrm{a}}$ 
PART IV: NUMERICAL MODEL

\section{Description}

\section{General}

72. The focus of the Tailwater Quality Numerical Model (TWQM) is to predict the downstream transformation of problem constituents, such as DO and several of the reduced substances (i.e., iron, manganese, sulfide, and ammonia). It is intended that the model require as little input data as possible, allowing modest resources for application. The obvious way to reduce input requirements is to restrict the model dimensionality; the model is $1-D$ in the streamwise direction. Another way to reduce input requirements is to restrict the model to steady-state applications so that time-varying input files are not required. Therefore, TWQM does not allow time-varying flow or water quality inputs, and a steady-state solution is performed.

73. Steady-state solutions for 1-D problems can often be performed analytically, rather than numerically (Dortch and Martin 1989). However, a numerical modeling approach was selected for the TWQM to allow flexibility in interactions of state variables. Additionally, with the microcomputer resources available today, numerical solutions are easily and rapidly attainable.

74. TWQM is based on the US Environmental Protection Agency (EPA) 1-D stream water quality model, QUAL2E (Brown and Barnwel1 1987). The major modification to QUAL2E was to include subroutines to model the reduced substances in tailwaters and a user interface to provide easier model application. QUAL2E was selected for several reasons: (a) the model is widely used and accepted, (b) the model provides for steady-state solutions, (c) the model contains other water quality processes that could be used if desired, and (d) the most recent version of QUAL2E had been developed for microcomputers with simpler input requirements.

75. The TWQM combines several components within a user-friendly interface that utilizes menus for selecting alternatives. In addition to the QUAL2E-based tailwater component, there is a reservoir release component. Reservoir release water quality is required for the upstream boundary condition of the stream component. The user may specify this information from observations or can predict the release concentrations based upon observed inpool concentrations using the SELECT model (Davis et al. 1987). Given the 
in-pool temperature stratification, the outlet features, release flow rate, and vertical distribution of water quality constituents, SELECT computes the release concentrations. Also included in SELECT is a structural reaeration component that predicts uptake of dissolved oxygen as flow passes through the release structure. Release concentrations are provided by SELECT to the tailwater component for predicting downstream concentrations. Except for DO, neither SELECT nor the tailwater model alters concentrations of water quality variables as flow passes through the outlet structure; in other words, variables are treated as conservative as they pass through the structure because of the short residence time in the structure. SELECT does allow the option of structural reaeration.

76. The combination of SELECT with the tailwater model allows the user to evaluate the impact on downstream water quality of various release schemes, such as hydropower retrofit or moving the vertical location of the intakes of the outlet structure.

77. TWQM has the capability of simulating up to 17 water quality constituents. Constituents, which can be modeled in any combination by the user, are:
a. DO.
b. $\mathrm{CBOD}$.
c. Temperature.
d. Algae as chlorophyll a.
e. Total organic nitrogen.
f. Ammonia nitrogen.
g. Nitrite and nitrate nitrogen.
h. Total organic phosphorus.
i. Dissolved inorganic (orthophosphate) phosphorus.
1. Dissolved (reduced) iron.
k. Dissolved (reduced) manganese.
1. Total dissolved sulfide ( $\mathrm{HS}^{-}$and $\mathrm{H}_{2} \mathrm{~S}$ ).
m. Iron sulfide.
n. Arbitrary nonconservative constituent.
o. Two conservative constituents.

Most of the above constituents were originally in QUAL2E; the reduced substances iron, manganese, sulfide, and iron sulfide were added. The model's compartmental diagram (Figure 4) illustrates the various state variables and how they interact. The model solves the steady-state mass balance equation 


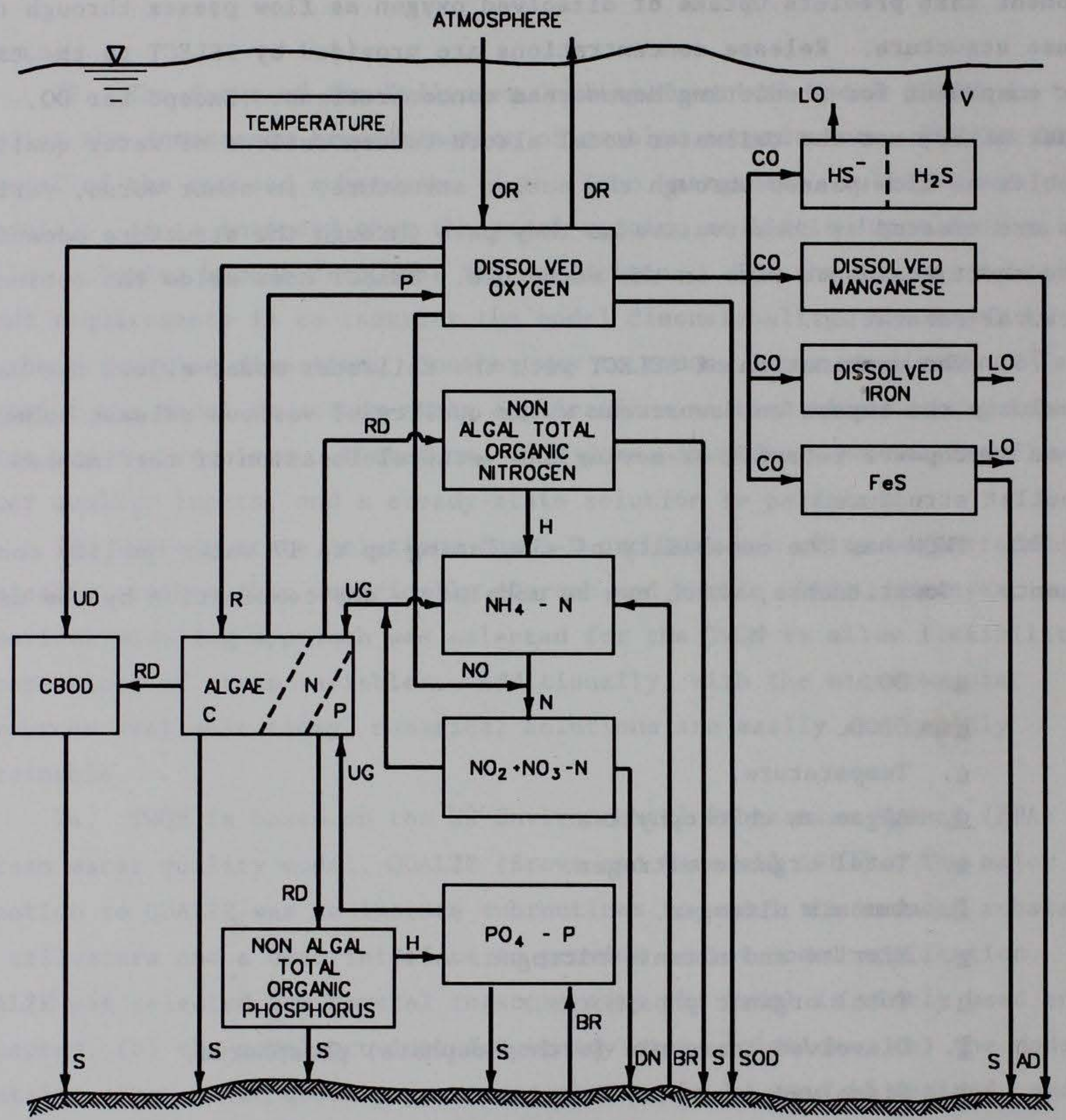

\begin{tabular}{|lc|}
\hline \multicolumn{3}{|c|}{ SEDIMENTS } \\
\hline S - SETTLING & UD - OXYGEN UPTAKE FROM DECAY \\
$R-$ RESPIRATION & NO - OXYGEN UPTAKE FROM NITRIFICATION \\
$P$ - PHOTOSYNTHESIS & UG - ALGAE UPTAKE FOR GROWTH \\
$H-$ HYDROLYSIS & RD - ALGA RELEASE FROM DEATH, EXCRETION \\
$N-$ NITRIFICATION & BR - BENTHIC RELEASE \\
OR - OXYGEN REAERATION & DR - OXYEN DEAERATION \\
AD - ADSORPTION & SOD - SED. OXYGEN DEMAND \\
CO - CHEMICAL OXIDATION & $V-$ VOLITILIZATION \\
DN - SEDIMENT DENITRIFICATION & LO - LOST THROUGH OXIDATION \\
\hline
\end{tabular}

Figure 4. Tailwater quality model compartmental diagram 
(i.e., mass transport equation or advection-diffusion equation with mass sources/sinks) for each state variable. The mass balance equation is referred to as the energy equation when temperature is the state variable.

78. The tailwater is physically described by subdividing the stream system into reaches (the basic division of the mode1). Reaches represent portions of the river having similar channel geometry, hydraulic characteristics, and chemical/biological coefficients. Reaches are further divided into equally spaced units called computational elements, or nodes. An example schematic of a modeled tailwater system is illustrated in Figure 5. Each computational element has inputs, outputs, and reaction terms. The energy and mass balance equations are solved simultaneously (implicitly) for all computational elements. This solution is repeated in an iterative fashion, using the previous solution results, until convergence for the steady-state solution is reached (i.e., the concentrations quit changing within a small tolerance).
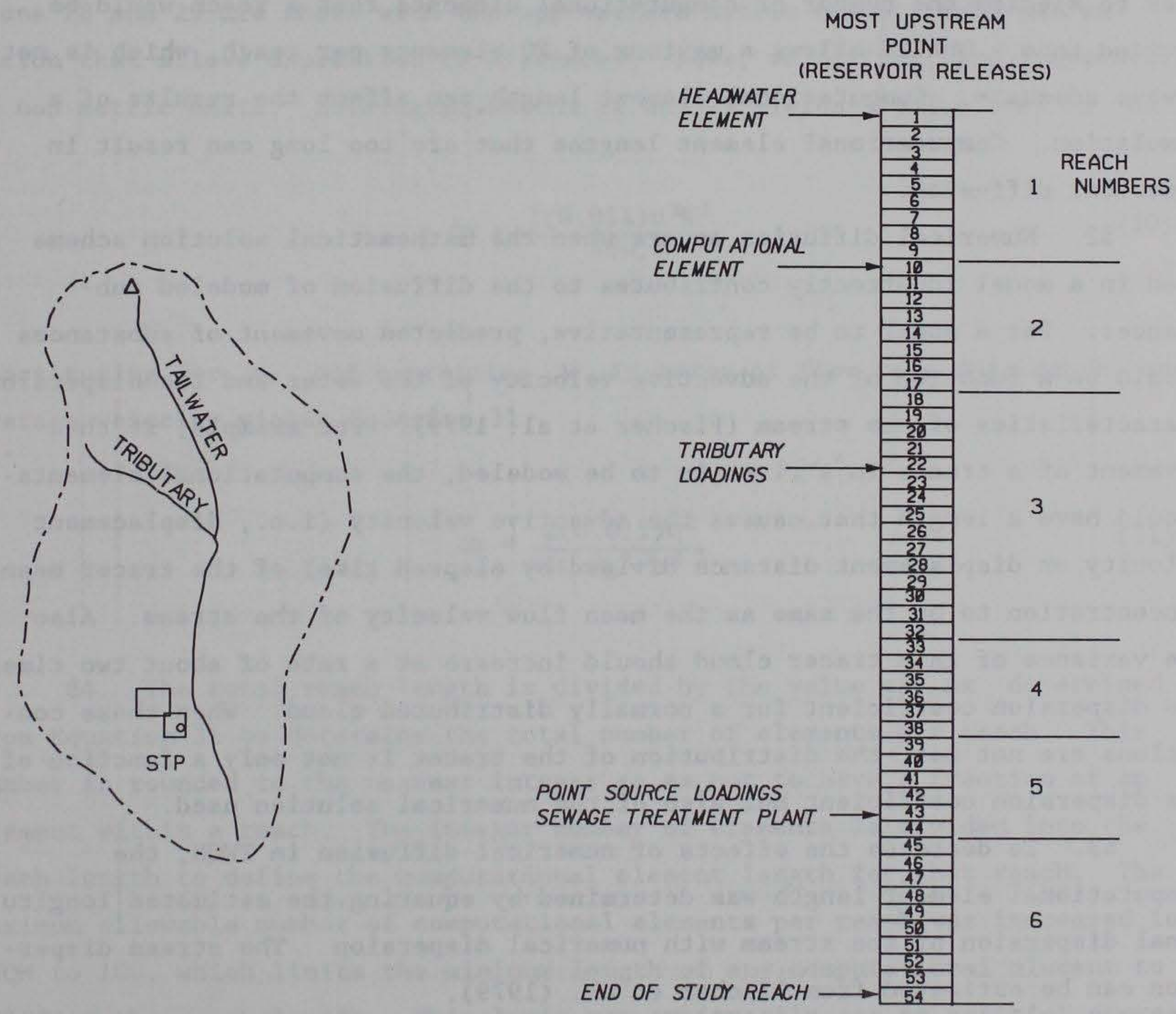

Figure 5. Example schematic of a model stream system 
79. The model assumes steady, nonuniform flow. Hydraulic conditions (velocity and depth) used within the energy and mass balance equations are entered for each reach and assumed uniform throughout the reach. Steady flow implies that the flow rate, velocity, width, and depth at any point in the stream are constant with time. Nonuniform flow is allowed, which means flow rate, velocity, width, and depth can change in the longitudinal direction from reach to reach.

80. Model processes of state variables that were added or kinetics that were modified are described in the sections that follow. As with any numerical solution, errors can be associated with the solution scheme. A description of the numerical error inherent in this model and the remedy are discussed in the next section on numerical diffusion.

Numerical diffusion

81. The version of QUAL2E from which TWQM was developed required the user to specify the number of computational elements that a reach would be divided into. QUAL2E allows a maximum of 20 elements per reach, which is not always adequate. Computational element length can affect the results of a simulation. Computational element lengths that are too long can result in numerical diffusion.

82. Numerical diffusion occurs when the mathematical solution scheme used in a model incorrectly contributes to the diffusion of modeled substances. For a model to be representative, predicted movement of substances should be a function of the advective velocity of the water and the dispersion characteristics of the stream (Fischer et al. 1979). For example, if the movement of a tracer in a river is to be modeled, the computational elements should have a length that causes the advective velocity (i.e., displacement velocity or displacement distance divided by elapsed time) of the tracer mean concentration to be the same as the mean flow velocity of the stream. Also, the variance of this tracer cloud should increase at a rate of about two times the dispersion coefficient for a normally distributed cloud. When these conditions are not met, the distribution of the tracer is not only a function of the dispersion coefficient but also of the numerical solution used.

83. To decrease the effects of numerical diffusion in TWQM, the computational element length was determined by equating the estimated longitudinal dispersion of the stream with numerical dispersion. The stream dispersion can be estimated from Fischer et al. (1979). 


$$
D_{s}=0.011 \frac{u^{2} w^{2}}{H u_{*}}
$$

where

$$
\begin{aligned}
& \mathrm{u}=\text { average stream velocity, } \mathrm{m} / \mathrm{sec} \\
& \mathrm{W}=\text { top width of stream, } \mathrm{m}
\end{aligned}
$$

Numerical dispersion for steady-state conditions can be computed (Roache 1972) from

$$
D_{n}=\frac{u \Delta x}{2}
$$

where $\Delta \mathrm{x}$ is the computational element length (meters). Variables in Equations 28 and 29 are shown with the appropriate metric units. TWQM has an option that allows expression of distances, flows, velocities, and temperature in non-metric units. Solving Equations 28 and 29 yields a value for $\Delta x$ of

$$
\Delta x=\frac{2(0.011) \mathrm{u}^{2} \mathrm{~W}^{2}}{\mathrm{uHu}}
$$

Substituting for $u_{*}$ and expressing $W$ in terms of flow rate $(Q)$, depth, and average velocity yields Equation 31 ,

$$
\Delta x=\frac{2(0.011) Q^{2}}{u H^{3.5} g^{0.5} s^{0.5}}
$$

84. The total reach length is divided by the value of $\Delta x$ determined from Equation 31 to determine the total number of elements per reach. This number is rounded to the nearest integer so as not to have a fraction of an element within a reach. The integer number of elements is divided into the reach length to define the computational element length for that reach. The maximum allowable number of computational elements per reach was increased in TWQM to 100 , which limits the minimum length of any computational element to $1 / 100$ of the reach length. This limit was arbitrarily set to restrict storage 
requirements of TWQM, but the user can easily increase this limit through a parameter statement in the source code.

85. To test the effectiveness of these changes, simulations were performed in which a nonconservative tracer was continuously injected at the dam and its steady-state concentration was predicted at distances downstream. In the case where the computational element length was determined (Figure 6a), the predicted concentrations were very close to those obtained using the analytical solution (Fischer et al. 1979).

$$
C=C_{0} \exp \left[\frac{-k x}{u}\left[\frac{2}{\alpha}(\sqrt{\alpha+1}-1)\right]\right]
$$

where

$$
\begin{aligned}
C_{0} & =\text { release concentration at } x=0, \mathrm{mg} / \ell \\
\mathrm{k} & =\text { reaction rate constant, day }{ }^{-1} \\
\alpha & =\frac{4 \mathrm{D}_{\mathrm{s}} \mathrm{k}}{\mathrm{u}^{2}}
\end{aligned}
$$

For the simulation in which the computational element length was set at an arbitrary length of 2 miles (Figure $6 \mathrm{~b}$ ), the predicted concentration is not as close to the analytical solution. Both simulations were performed using the same initial concentrations, velocities, and channel geometry. The only difference between the two simulations was the computational element length.

86. QUAL2E, and therefore TWQM, require that the length of computational elements be the same in all reaches. In simulations performed using multiple reaches, the minimum computational element length determined in any reach is used for all reaches. In this case the reach length of the other reaches might be increased or decreased slightly to prevent a reach from containing a fraction of an element.

87. QUAL2E requires the user to input the element type (headwater, standard, point load, end) for each computational element. In TWQM this process has been automated due to the potentially large number of elements used per reach. The only user input requirements of this type are the locations in river miles of point loads (including waste discharges and tributaries) or withdrawals within a reach. 


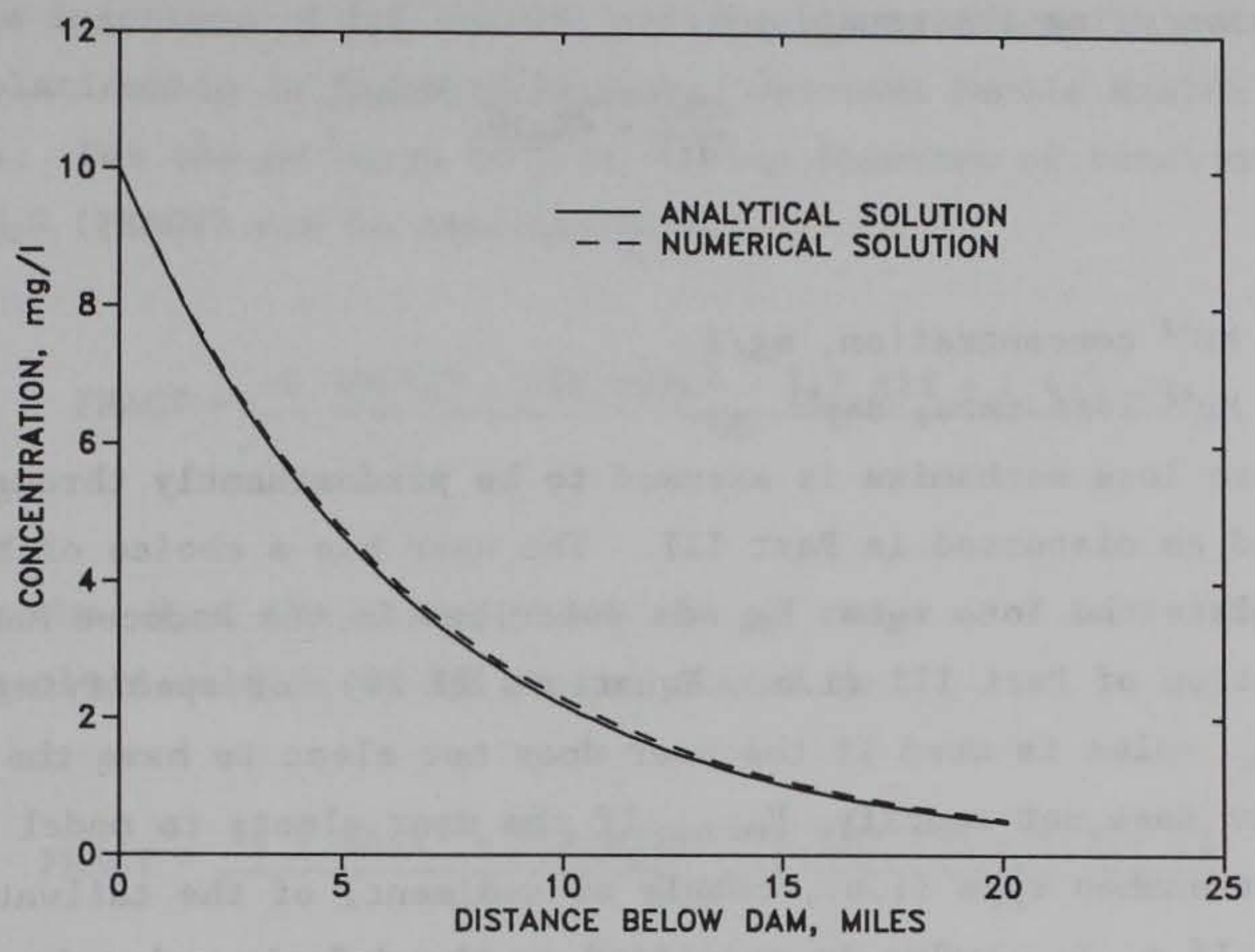

a. Term $\Delta \mathrm{x}$ computed to reduce model numerical diffusion

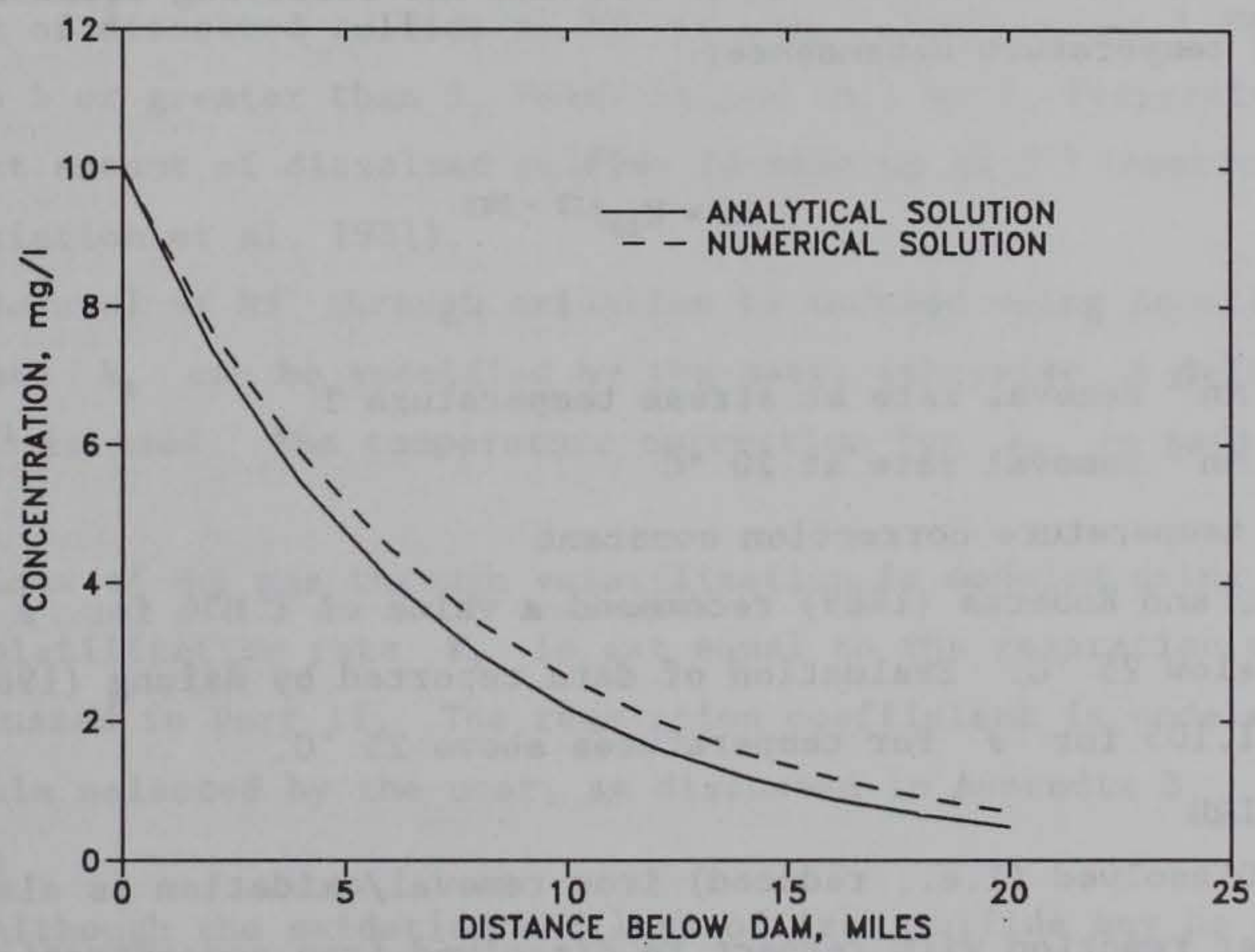

b. Term $\Delta x$ equals 2.0 miles in the numerical model

Figure 6. Results of stream transport test 


\section{Dissolved manganese}

88. Dissolved (i.e., reduced) manganese removal is modeled as a firstorder reaction using the equation

$$
\frac{d M n}{d t}=-K_{M n} M n
$$

where

$$
\begin{aligned}
\mathrm{Mn} & =\mathrm{Mn}^{+2} \text { concentration, } \mathrm{mg} / \ell \\
\mathrm{K}_{\mathrm{Mn}} & =\mathrm{Mn}^{+2} \text { loss rate, day }{ }^{-1}
\end{aligned}
$$

The manganese loss mechanism is assumed to be predominantly through adsorption onto the bed as discussed in Part III. The user has a choice of having the model calculate the loss rate $K_{\mathrm{Mn}}$ as described in the Reduced Manganese Removal section of Part III (i.e., Equations 23-26), or specifying $K_{\text {Mn }}$. A default $K_{\mathrm{Mn}}$ value is used if the user does not elect to have the model predict $K_{M_{n}}$ or does not specify $K_{M n}$. If the user elects to model the removal rate, the streambed type (i.e., cobble or sediment) of the tailwater must be specified. If a $K_{M_{n}}$ value is specified or the default value is used, the value entered is assumed to be at $20^{\circ} \mathrm{C}$, and the following equation is used to correct for temperature dependence:

$$
\mathrm{K}_{\mathrm{T}}=\mathrm{K}_{20} \theta(\mathrm{T}-20)
$$

where

$$
\begin{aligned}
\mathrm{K}_{\mathrm{T}} & =\mathrm{Mn}^{+2} \text { removal rate at stream temperature } \mathrm{T} \\
\mathrm{K}_{20} & =\mathrm{Mn}^{+2} \text { removal rate at } 20{ }^{\circ} \mathrm{C} \\
\theta & =\text { temperature correction constant }
\end{aligned}
$$

Hess, Byung, and Roberts (1989) recommend a value of 1.054 for $\theta$ for temperatures below $25^{\circ} \mathrm{C}$. Evaluation of data reported by Hsiung (1987) suggested a value of 1.105 for $\theta$ for temperatures above $25^{\circ} \mathrm{C}$.

\section{Dissolved iron}

89. Dissolved (i.e., reduced) iron removal/oxidation is also modeled as a first-order reaction with respect to dissolved iron concentration. The loss rate $\mathrm{K}_{\mathrm{Fe}}$ can be calculated by the model (i.e., using Equations 6 and 7 ) or specified by the user. Again, if the user does not specify a value or does not elect to let the model compute the loss rate, a default value will be used. When the default value is used or a value is specified, the temperature dependence is taken into account using Equation 7. 


\section{Dissolved sulfide}

90. Total dissolved sulfide is a modeled state variable composed of $\mathrm{HS}^{-}$ and $\mathrm{H}_{2} \mathrm{~S}$. The fractions of $\mathrm{H}_{2} \mathrm{~S}$ and $\mathrm{HS}^{-}$present are estimated based on the $\mathrm{pH}-$ dependent relationship in Standard Methods (American Public Health Association et al. 1981). For the $\mathrm{pH}$ range of 5 to 7 , the fraction of total dissolved sulfide as $\mathrm{H}_{2} \mathrm{~S}$ (FRACT) can be calculated as

$$
\text { FRACT }=\frac{-8.3813 X^{3}+135.898 X^{2}-742.31 X+1,461.46}{100}
$$

where $\mathrm{X}$ is the $\mathrm{pH}$ of the stream. For the $\mathrm{pH}$ range of 7 to 9 , the fraction of total dissolved sulfide as $\mathrm{H}_{2} \mathrm{~S}$ is calculated as

$$
\text { FRACT }=\frac{-8.25406 X^{3}+213.821 X^{2}-1.852 .79 X+5,374.11}{100}
$$

The fraction of dissolved sulfide as $\mathrm{HS}^{-}$is then calculated as 1-FRACT. If $\mathrm{pH}$ is less than 5 or greater than 9, FRACT is set to 1 or 0 , respectively. An insignificant amount of dissolved sulfide is made up of $\mathrm{s}^{-2}$ (American Public Health Association et al. 1981).

91. Removal of $\mathrm{HS}^{-}$through oxidation is modeled using Equation 8. The oxidation rate $k_{s}$ can be specified by the user; otherwise, a default value of $25.0 \mathrm{day}^{-1}$ is used. The temperature correction for $k_{s}$ is made with Equation 9.

92. Loss of $\mathrm{H}_{2} \mathrm{~S}$ gas through volatilization is modeled using Equation 11 where the volatilization rate $K_{s}$ is set equal to the reaeration coefficient $\mathrm{K}_{2}$, as discussed in Part II. The reaeration coefficient is modeled according to the formula selected by the user, as discussed in Appendix B.

\section{Iron sulfide}

93. Although the oxidation and loss of iron sulfide may be complex, a simple approach for modeling is proposed here, considering the lack of better information and supporting data at this time. The loss of iron sulfide from the tailwater is accounted for by two mechanisms, first-order oxidation (i.e., Equation 1) in the water column and settling to the bottom. Thus, the kinetic equation for iron sulfide is 


$$
\frac{d(\mathrm{FeS})}{d t}=-\left(\mathrm{K}_{\mathrm{FeS}}+\frac{\mathrm{W}_{\mathrm{s}}}{\mathrm{H}}\right)(\mathrm{FeS})
$$

where

$$
\begin{aligned}
(\mathrm{FeS}) & =\text { iron sulfide concentration, } \mathrm{mg} / \ell \\
\mathrm{K}_{\mathrm{FeS}} & =\text { first-order oxidation rate, day }{ }^{-1} \\
\mathrm{~W}_{\mathrm{s}} & =\text { settling rate of } \mathrm{FeS}, \mathrm{m} / \text { day }
\end{aligned}
$$

The settling and oxidation rates are either specified by the user or set to the default values of $1.0 \mathrm{~m} /$ day and 38.0 day $^{-1}$, respectively.

\section{Nitrification and denitrification}

94. QUAL2E contains algorithms for the nitrogen cycle, including mineralization of organic nitrogen to ammonium nitrogen, nitrification from ammonium to nitrite and from nitrite to nitrate nitrogen, and denitrification. These algorithms were retained for use in the TWQM with some minor modifications. The method for computing the nitrification rate discussed earlier in Part III (i.e., Equation 27) was included as a user option. Additionally, nitrite nitrogen was removed as a state variable since it oxidizes rapidly and its presence only further complicates the model. Therefore, ammonium nitrogen is oxidized directly to nitrate nitrogen. A first-order removal mechanism for nitrate nitrogen was added to represent denitrification by sediments. This denitrification mechanism is independent of DO concentration, and the user can specify the first-order rate or use the default value.

\section{Dissolved oxygen}

95. The equation for dissolved oxygen in QUAL2E had to be modified to allow proper representation of the various DO sinks caused by the oxidation of reduced substances in the tailwater. The sinks of DO are:

a. Algal respiration.

b. Decomposition of organic carbon (i.e., CBOD decay).

c. Nitrification of ammonium nitrogen to nitrate nitrogen.

d. Oxidation of reduced manganese sorbed onto the bed.

e. Oxidation of reduced (i.e., dissolved) iron.

f. Oxidation of iron sulfide, both in the water column and in the bed.

g. Oxidation of $\mathrm{HS}^{-}$.

h. Sediment oxygen demand (SOD). 
96. $\mathrm{CBOD}$ is used to represent the oxygen uptake due to decomposition of organic carbon. The kinetics and oxidation of $C B O D$ decay and algal respiration in QUAL2E were not modified. The oxygen uptake associated with nitrification was altered to reflect that the intermediate step of nitrification to nitrite was eliminated. Oxygen uptake due to oxidation of dissolved iron, iron sulfide in the water column, and $\mathrm{HS}^{-}$were included by subtracting the three corresponding stoichiometric sink terms from the right side of the oxygen mass balance equation. QUAL2E contained a loss mechanism of DO through SOD. The SOD for TWQM is considered to be caused by the decomposition of organic material in the bottom sediments.

97. The oxidation of inorganic matter on the bottom (i.e., sorbed, reduced manganese and iron sulfide that settles to the bottom) must also be included in the DO balance. Matter lost from the water column accumulates in the bed for subsequent oxidation. The concentration of manganese and iron sulfide in the bed can be derived from the steady-state mass balance of these two substances in a bed control volume

$$
C_{b}=\frac{w_{s} C}{K_{b} V_{b}}
$$

where

$$
\begin{aligned}
\mathrm{C}_{\mathrm{b}}= & \text { concentration of reduced manganese or iron sulfide in bed, } \mathrm{mg} / \ell \\
\mathrm{w}= & \text { loading rate (i.e., mass transfer rate or settling rate) to } \\
& \text { bed, } \mathrm{m} / \text { day } \\
\mathrm{A}_{\mathrm{s}}= & \text { surface area of bed control volume, } \mathrm{m}^{2} \\
\mathrm{C}= & \text { concentration of reduced manganese or iron sulfide in water } \\
& \text { column, mg/ }
\end{aligned}
$$

The oxidation of these substances creates an additional sediment oxygen demand that can be calculated by

$$
\Delta \mathrm{SOD}=\frac{\alpha \mathrm{K}_{\mathrm{b}} \mathrm{C}_{\mathrm{b}} \mathrm{V}_{\mathrm{b}}}{\mathrm{A}_{\mathrm{s}}}=\alpha w \mathrm{C}
$$


where

$$
\begin{aligned}
\Delta \mathrm{SOD}= & \text { additional } \mathrm{SOD} \text { resulting from manganese or iron sulfide } \\
& \text { oxidation in bed, } \mathrm{g} \mathrm{O}_{2} /\left(\mathrm{m}^{2} / \text { day }\right) \\
\alpha= & \text { stoichiometric conversion for } \mathrm{mg} / \ell \text { of } \mathrm{O}_{2} \text { uptake per } \mathrm{mg} / \ell \\
& \text { of substance oxidized, nondimensional }
\end{aligned}
$$

Therefore, the steady-state additional SOD depends on the loading rate from the water column to the bed. Water column oxygen uptake resulting from SOD is accomplished in the DO balance by multiplying the SOD by the surface area of the bed and dividing by the volume of the water column, which is the same as SOD/H . Therefore, the water column DO sink arising from Equation 39 is computed by $\alpha(\mathrm{w} / \mathrm{H}) \mathrm{C}$, where $\mathrm{w}$ for reduced manganese is actually $\mathrm{V}_{\mathrm{s}}$ computed from Equations 25 and 26.

98. The additional sink terms arising from oxidation reactions of reduced substances that were included in the DO balance are summarized as follows :

$$
\begin{gathered}
\text { Dissolved iron }=\alpha_{\mathrm{Pe}} \mathrm{K}_{\mathrm{P \theta}}\left(\mathrm{Fe}^{++}\right) \\
\text {Dissolved sulfide }=\alpha_{\mathrm{HS}} \mathrm{K}_{\mathrm{HS}}\left(\mathrm{HS}^{-}\right) \\
\text {Reduced manganese }=\alpha_{\mathrm{Mn}} \mathrm{K}_{\mathrm{Mn}}\left(\mathrm{Mn}^{++}\right) \\
\text {Iron sulfide }=\alpha_{\mathrm{FeS}}\left(\mathrm{K}_{\mathrm{FeS}}+\frac{\mathrm{W}_{\mathrm{B}}}{\mathrm{H}}\right)(\mathrm{FeS})
\end{gathered}
$$

where the substance quantities in parentheses are concentrations in milligrams per liter. The default values for the parameters in the above relations are shown in Table 6 . The sources of DO, reaeration and algal photosynthesis, were not modified. It will be necessary to model algae in many tailwater applications of TWQM. 
$\alpha_{\mathrm{Fe}}$, DO uptake conversion for $\mathrm{Fe}^{++}$oxidation $0.14 \mathrm{mg} / \ell \mathrm{O}_{2}$ per $\mathrm{mg} / \ell \mathrm{Fe}^{+2}$ $\alpha_{\mathrm{HS}}$, DO uptake conversion for $\mathrm{HS}^{-}$oxidation $1.38 \mathrm{mg} / \ell \mathrm{O}_{2}$ per $\mathrm{mg} / \ell \mathrm{s}^{-2}$ $\alpha_{\mathrm{Mn}}$, DO uptake conversion for $\mathrm{Mn}^{++}$oxidation $0.29 \mathrm{mg} / \ell \mathrm{O}_{2}$ per $\mathrm{mg} / \ell \mathrm{Mn}^{+2}$ $\alpha_{\mathrm{FeS}}$, DO uptake conversion for FeS oxidation $\mathrm{K}_{\mathrm{Fe}}$, oxidation rate of $\mathrm{Fe}^{++}$

$\mathrm{K}_{\mathrm{HS}}$, oxidation rate of $\mathrm{HS}^{-}$ $0.73 \mathrm{mg} / \ell \mathrm{O}_{2}$ per $\mathrm{mg} / \ell \mathrm{FeS}$ $\left(\right.$ day $\left.^{-1}\right) *$ $\left(\right.$ day $\left.^{-1}\right) *$

$\mathrm{K}_{\mathrm{Mn}}$, loss rate of $\mathrm{Mn}^{++}$from water column $\left(\right.$ day $\left.^{-1}\right) *$

$\mathrm{K}_{\mathrm{FeS}}$, oxidation rate of $\mathrm{FeS}$ in water column 38.0 day $^{-1}$ $W_{s}$, settling rate of $\mathrm{FeS}$ from water column $1.0 \mathrm{~m} /$ day

* Parameter predicted by the model for default.

\section{Application}

\section{General}

99. TWQM was applied to one data set for each of the four field sites (Lake Greeson, September 1987; Nimrod Reservoir, August 1989; Rough River Reservoir, August 1988; and Canyon Reservoir, September 1988) discussed in Nix et al. (1991). All four data sets were obtained with the steady-state method of sampling (Nix et al. 1991). Water quality constituents modeled during each application were DO, CBOD, ammonium nitrogen, organic nitrogen, nitrate nitrogen, dissolved iron (i.e., $\mathrm{Fe}^{+2}$ ), dissolved manganese (i.e., $\mathrm{Mn}^{+2}$ ), and total dissolved sulfide (if measured). Iron sulfide was also modeled for Rough River. Temperature and $\mathrm{pH}$ were not modeled but were input for each reach. One data set from each site was selected for model verification.

100. Reaction rates for $\mathrm{Mn}^{+2}, \mathrm{Fe}^{+2}$, and $\mathrm{NH}_{4}$ removal were initially modeled using equations discussed in previous sections of this report. Concentrations of $\mathrm{Mn}^{+2}, \mathrm{Fe}^{+2}$, and $\mathrm{NH}_{4}$ were compared with observed results to determine how well removal of the reduced species was predicted throughout the tailwater. If predictions did not compare well with observations, the reaction rate was changed to yield concentrations similar to those observed. All other reaction rates (e.g., organic nitrogen hydrolysis) were set to values recommended by Brown and Barnwell (1987). Table 7 contains final values used 
for the input parameters, such as hydraulic data, headwater boundary conditions, ambient constants, and reaction rates, for each field site.

101. The following section presents application results. The order of presentation is to discuss the results for each water quality constituent as modeled for all sites (e.g., results of modeling $\mathrm{Mn}^{+2}$ for all sites), rather than to discuss the results of all water quality constituents for each site. Results

102. Final calibration results for all four sites are shown in Figures 7-10. Final results for $\mathrm{Mn}^{+2}$ are shown in Figures $7 \mathrm{~b}$ (Greeson), 8b (Nimrod), 9b (Rough River), and $10 \mathrm{~b}$ (Canyon). $\mathrm{Mn}^{+2}$ removal was successfully modeled at three of the sites using the predictive equations for $K_{\text {tn }}$ (i.e., Equations 22-26), resulting in acceptable estimations of $\mathrm{Mn}^{+2}$ concentrations compared with observed values. However, for the Rough River application, the predictive equations for $\mathrm{K}_{\mathrm{Mn}}$ caused $\mathrm{Mn}^{+2}$ to be removed too quickly, especially in the upper reaches. The first four reaches (approximately the upper $10.0 \mathrm{~km}$ ) of the modeled Rough River tailwater are in the pool created by the mill dam, referred to as Falls of Rough. Conditions within this pool are much different from the downstream reach below Falls of Rough. By specifying low $\mathrm{K}_{\mathrm{Mn}}$ values that are consistent with those estimated within the mill dam pool, much better results were obtained (Figure $9 \mathrm{~b}$ ). During data analysis (Part III), it was observed that the $K_{\text {m n }}$ values measured in the pooled reaches of Rough River were much less than those measured at the other sites. A higher value of $K_{\mathrm{Mn}}$, similar to values observed at the other sites, was used in the free-flowing reach below the mill dam.

103. The predictive equations for the manganese removal rate $K_{M n}$ probably did not perform well for the pooled reaches of the Rough River tailwater because of the conditions that normally exist during the summer months at this site. The releases from Rough River Dam are usually quite low (e.g., 20 cfs*). A low-flow and a high-flow condition were sampled in this study. The results presented here are for the high flow of $200 \mathrm{cfs}$. For this flow, the water in the pool was well mixed from surface to bottom. However, at the normal low flows, the Fall of Rough pool slightly stratifies, and the release water plunges under a warmwater wedge. This plunging phenomenon prevents the release water, which is rich in reduced substances (e.g., dissolved

* A table of factors for converting non-SI units of measurement to SI (metric) units is presented on page 3. 
Table 7

Input Data for Each Application*

\begin{tabular}{|c|c|c|c|c|c|c|c|c|}
\hline \multirow{2}{*}{$\begin{array}{l}\text { Field } \\
\text { Site } \\
\end{array}$} & \multirow[b]{2}{*}{ Data Type } & \multirow[b]{2}{*}{ Parameter } & \multicolumn{6}{|c|}{ Reach No. } \\
\hline & & & 1 & 2 & 3 & 4 & 5 & 6 \\
\hline \multirow[t]{23}{*}{ Greeson } & Hydraulic & Depth ( $f t)$ & 3.11 & 2.50 & 2.80 & 2.63 & & \\
\hline & & Velocity (ft/sec) & 1.65 & 1.50 & 0.88 & 0.75 & & \\
\hline & & $\begin{array}{l}\text { Start of reach }(\mathrm{km}) \\
\text { Slope }\end{array}$ & $\begin{array}{l}170.27 \\
0.0016\end{array}$ & 166.41 & 161.26 & 159.65 & & \\
\hline & Headwater & Flow (cfs) & 500.00 & & & & & \\
\hline & & DO $(\mathrm{mg} / \mathrm{l})$ & 4.40 & & $\theta$ & & & \\
\hline & & CBOD $(\mathrm{mg} / \mathrm{l}) * *$ & 2.00 & & & & & \\
\hline & & $\mathrm{Fe}^{+2}(\mathrm{mg} / \ell)$ & 0.04 & & & & & \\
\hline & & $\mathrm{Mn}^{+2}(\mathrm{mg} / \mathrm{l})$ & 0.09 & & & & & \\
\hline & & $\mathrm{pH}$ & 6.15 & & & & & \\
\hline & & Org-N (mg/l) & 0.18 & & & & & \\
\hline & & $\mathrm{NH}_{4}-\mathrm{N}(\mathrm{mg} / \ell)$ & 0.02 & & & & & \\
\hline & & $\mathrm{NO}_{3}-\mathrm{N}(\mathrm{mg} / \mathrm{l})$ & 0.17 & & & & & \\
\hline & Ambient & Temperature $\left({ }^{\circ} \mathrm{C}\right)$ & 14.04 & 15.40 & 16.00 & 15.50 & & \\
\hline & constants & & 6.15 & 6.40 & 6.30 & 6.80 & & \\
\hline & Reaction & CBOD (1/day) & 0.10 & 0.10 & 0.10 & 0.25 & & \\
\hline & rates & SOD $\left(\mathrm{g} / \mathrm{m}^{2}\right.$ day $\left.^{-1}\right)$ & 0.00 & 0.00 & 0.00 & 2.0 & & \\
\hline & & $\mathrm{K}_{2}$ value & 6.24 & 7.03 & 5.62 & 0.62 & & \\
\hline & & Org $-N$ hydrolysis ( $1 /$ day) & 0.20 & & & & & \\
\hline & & Org $-N$ settling ( $1 /$ day) & 0.10 & & & & & \\
\hline & & $\mathrm{NH}_{4}-\mathrm{N}$ (1/day) & Modeled & & & . & & \\
\hline & & $\mathrm{Fe}^{+2}$ oxidation ( $1 /$ day) & Modeled & & & 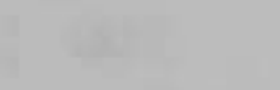 & & \\
\hline & & $\mathrm{Mn}^{+2}$ oxidation ( $1 /$ day) & Modeled & & & & & \\
\hline & & Denitrification ( $1 /$ day) & 0.00 & & & & & \\
\hline \multirow[t]{24}{*}{ Nimrod } & Hydraulic & Depth ( $f t)$ & 2.00 & 2.56 & 3.57 & & & \\
\hline & & Velocity (ft/sec) & 0.56 & 0.45 & 0.27 & t & & \\
\hline & & Start of reach $(\mathrm{km})$ & 100.74 & 97.85 & 96.08 & $x^{2}$ & & \\
\hline & 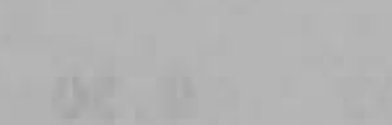 & Slope & 0.001 & & & & & \\
\hline & Headwater & Temperature $\left({ }^{\circ} \mathrm{C}\right)$ & 25.88 & & & & & \\
\hline & & Flow (cfs) & 200.00 & & & & & \\
\hline & & DO $(\mathrm{mg} / \mathrm{l})$ & 7.00 & & & & & \\
\hline & & CBOD $(\mathrm{mg} / \mathrm{l})$ & 1.00 & & & 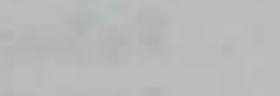 & & \\
\hline & & Sulfide $(\mathrm{mg} / \mathrm{l})$ & 0.016 & (1) & (a) & $y^{2}$ & & \\
\hline & & $\mathrm{Fe}^{+2}(\mathrm{mg} / \mathrm{l})$ & 1.00 & & & $2 z$ & & \\
\hline & & $\mathrm{Mn}^{+2}(\mathrm{mg} / \ell)$ & 1.20 & & & & & \\
\hline & & $\mathrm{pH}$ & 6.50 & & & 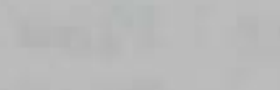 & & \\
\hline & & $\operatorname{Org}-\mathrm{N}(\mathrm{mg} / \mathrm{l})$ & 0.32 & & & the & & \\
\hline & & $\mathrm{NH}_{4}-\mathrm{N}(\mathrm{mg} / \mathrm{l})$ & 0.28 & & & & & \\
\hline & & $\mathrm{NO}_{3}-\mathrm{N}(\mathrm{mg} / \mathrm{l})$ & 0.03 & & & & & \\
\hline & Ambient & Temperature $\left({ }^{\circ} \mathrm{C}\right)$ & 25.88 & 26.60 & 27.00 & 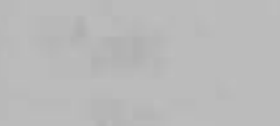 & & \\
\hline & constants & $\mathrm{pH}$ & 6.50 & & & & & \\
\hline & Reaction & CBOD (1/day) & 0.15 & & & 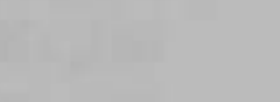 & & \\
\hline & rates & $\operatorname{SOD}\left(\mathrm{g} / \mathrm{m}^{2} \mathrm{day}^{-1}\right)$ & 2.00 & & & 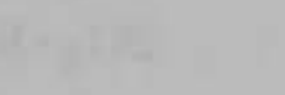 & & \\
\hline & & $\mathrm{K}_{2}$ option & 3.00 & & & & & \\
\hline & & Org-N hydrolysis ( 1 /day) & 0.2 & & 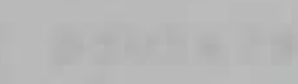 & 1 & & \\
\hline & & Org $-N$ settling ( $1 /$ day) & 0.1 & & & 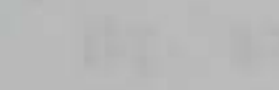 & & \\
\hline & & $\mathrm{NH}_{4}-\mathrm{N}(1 /$ day $)$ & 1.75 & & & & & \\
\hline & & ( Co & ntinued) & & & & & \\
\hline
\end{tabular}

* Parameters were constant throughout reaches unless otherwise indicated.

** $\mathrm{CBOD}$ is 5 day CBOD.

(Sheet 1 of 3 ) 
Table 7 (Continued)

\begin{tabular}{|c|c|c|c|c|c|c|c|c|}
\hline Field & & & & & Reach & No. & & \\
\hline Site & Data Type & Parameter & 1 & 2 & 3 & 4 & 5 & 6 \\
\hline $\begin{array}{l}\text { Nimrod } \\
\text { (Cont.) }\end{array}$ & & $\begin{array}{l}\mathrm{Fe}^{+2} \text { (1/day) } \\
\mathrm{Mn}^{+2} \text { (1/day) } \\
\text { Sulfide (1/day) } \\
\text { Denitrification (1/day) }\end{array}$ & $\begin{array}{l}\text { Modeled } \\
\text { Modeled } \\
1.00 \\
2.25\end{array}$ & 0.50 & 0.10 & & & \\
\hline $\begin{array}{l}\text { Rough } \\
\text { River }\end{array}$ & Hydraulic & $\begin{array}{l}\text { Depth (ft) } \\
\text { Velocity }(\mathrm{ft} / \mathrm{sec}) \\
\text { Start of reach }(\mathrm{km}) \\
\text { Slope }\end{array}$ & $\begin{array}{c}5.50 \\
0.57 \\
143.88 \\
0.0023\end{array}$ & $\begin{array}{r}6.00 \\
0.30 \\
141.14\end{array}$ & $\begin{array}{r}9.00 \\
0.26 \\
138.89\end{array}$ & $\begin{array}{r}10.70 \\
0.33 \\
135.67\end{array}$ & $\begin{array}{r}3.00 \\
0.62 \\
133.58\end{array}$ & \\
\hline & Headwater & $\begin{array}{l}\text { Flow (cfs) } \\
\mathrm{DO}(\mathrm{mg} / \ell) \\
\mathrm{CBOD}(\mathrm{mg} / \ell) \\
\mathrm{Fe}^{+2}(\mathrm{mg} / \ell) \\
\mathrm{FeS}(\mathrm{mg} / \ell) \\
\mathrm{Mn}^{+2}(\mathrm{mg} / \ell) \\
\mathrm{pH} \\
\text { Org }-\mathrm{N}(\mathrm{mg} / \ell) \\
\mathrm{NH}_{4}-\mathrm{N}(\mathrm{mg} / \ell) \\
\mathrm{NO}_{3}-\mathrm{N}(\mathrm{mg} / \ell)\end{array}$ & $\begin{array}{r}200.00 \\
8.60 \\
1.00 \\
0.89 \\
2.50 \\
2.03 \\
7.30 \\
0.64 \\
1.06 \\
0.01\end{array}$ & & & 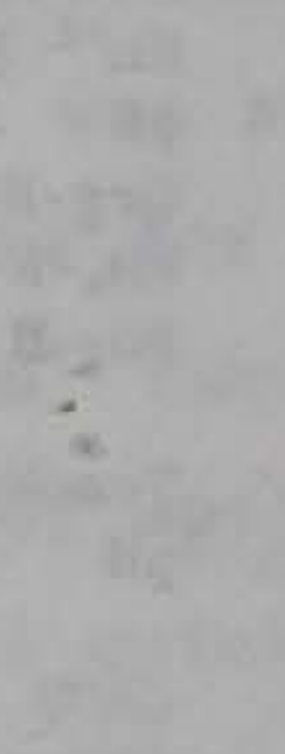 & & \\
\hline & $\begin{array}{l}\text { Ambient } \\
\text { constants }\end{array}$ & $\begin{array}{l}\text { Temperature }\left({ }^{\circ} \mathrm{C}\right) \\
\mathrm{pH}\end{array}$ & $\begin{array}{r}15.20 \\
7.30\end{array}$ & $\begin{array}{r}15.30 \\
7.30\end{array}$ & $\begin{array}{r}15.40 \\
7.20\end{array}$ & $\begin{array}{r}16.50 \\
7.30\end{array}$ & $\begin{array}{r}17.30 \\
7.20\end{array}$ & \\
\hline & $\begin{array}{l}\text { Reaction } \\
\text { rates }\end{array}$ & 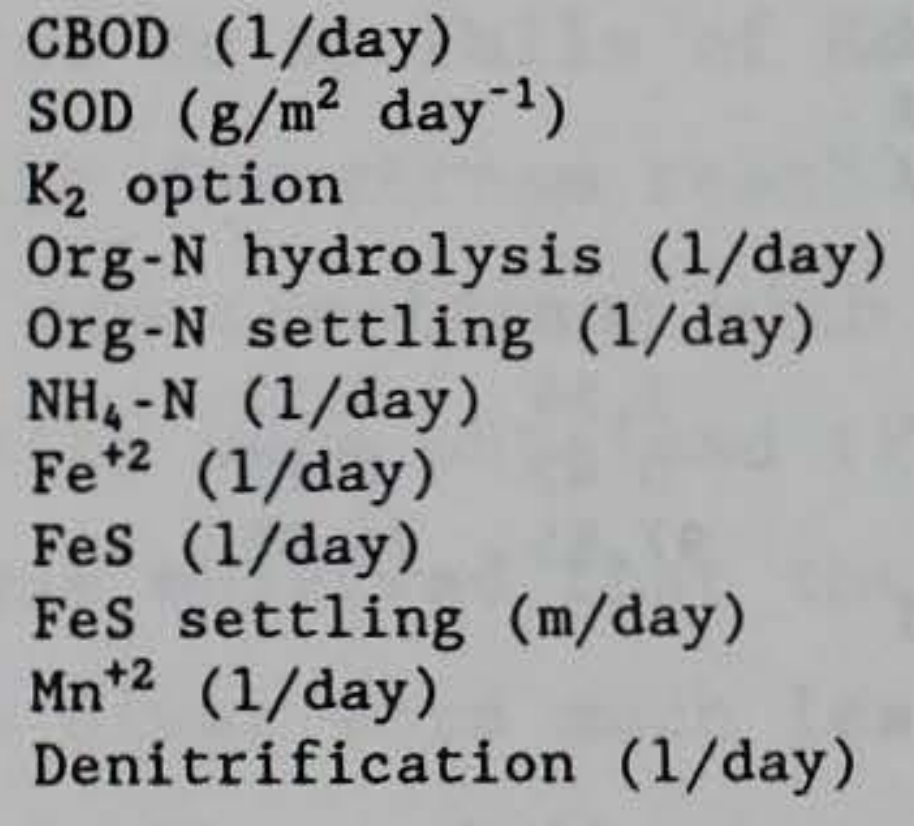 & $\begin{array}{c}0.20 \\
1.80 \\
3.00 \\
0.20 \\
0.10 \\
0.20 \\
\text { Modeled } \\
2.00 \\
0.00 \\
0.05 \\
3.50\end{array}$ & $\begin{array}{l}0.20 \\
0.05\end{array}$ & 0.20 & $\begin{array}{l}0.20 \\
0.03\end{array}$ & $\begin{array}{l}0.70 \\
0.50\end{array}$ & \\
\hline Canyon & Hydraulic & $\begin{array}{l}\text { Depth }(\mathrm{ft}) \\
\text { Velocity }(\mathrm{ft} / \mathrm{sec}) \\
\text { Start of reach }(\mathrm{km}) \\
\text { Slope }\end{array}$ & $\begin{array}{r}1.30 \\
1.04 \\
487.63 \\
0.00144\end{array}$ & 486.02 & 484.73 & 482.32 & 477.65 & 473.15 \\
\hline & Headwater & $\begin{array}{l}\text { Flow (cfs) } \\
\text { DO (mg/l) } \\
\text { CBOD (mg/l) } \\
\text { Sulfide (mg/l) } \\
\mathrm{Fe}^{+2}(\mathrm{mg} / \ell) \\
\mathrm{Mn}^{+2}(\mathrm{mg} / \ell) \\
\mathrm{pH} \\
\text { Org }-\mathrm{N}(\mathrm{mg} / \ell) \\
\mathrm{NH}_{4}-\mathrm{N}(\mathrm{mg} / \ell) \\
\mathrm{NO}_{3}-\mathrm{N}(\mathrm{mg} / \ell)\end{array}$ & $\begin{array}{r}114.00 \\
8.80 \\
1.00 \\
0.04 \\
0.012 \\
0.168 \\
7.50 \\
0.00 \\
0.11 \\
0.04\end{array}$ & & & & & \\
\hline & $\begin{array}{l}\text { Ambient } \\
\text { constants }\end{array}$ & $\begin{array}{l}\text { Temperature }\left({ }^{\circ} \mathrm{C}\right) \\
\mathrm{pH}\end{array}$ & $\begin{array}{r}17.20 \\
7.50\end{array}$ & $\begin{array}{r}17.70 \\
7.70\end{array}$ & $\begin{array}{r}19.10 \\
7.80\end{array}$ & $\begin{array}{r}20.60 \\
7.80\end{array}$ & $\begin{array}{r}22.50 \\
7.90\end{array}$ & $\begin{array}{r}23.10 \\
7.90\end{array}$ \\
\hline
\end{tabular}

(Continued)

(Sheet 2 of 3 ) 
Table 7 (Concluded)

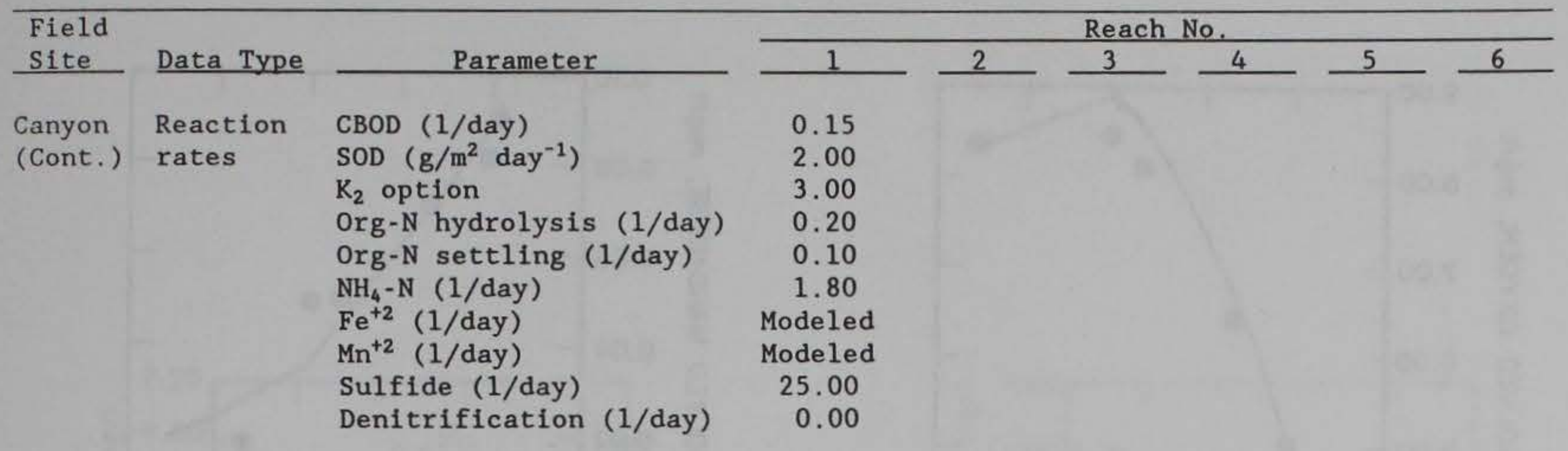




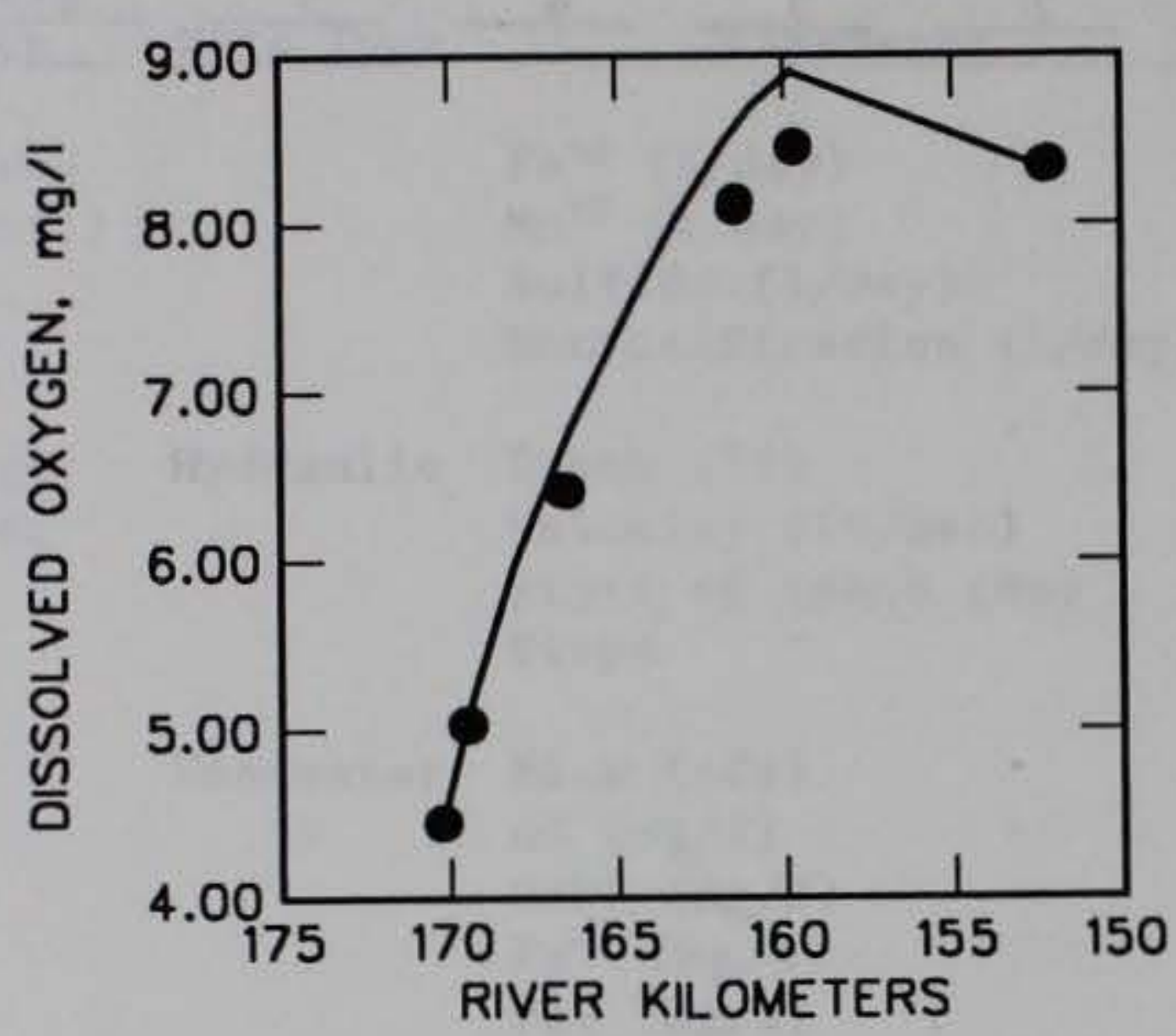

a. Dissolved oxygen

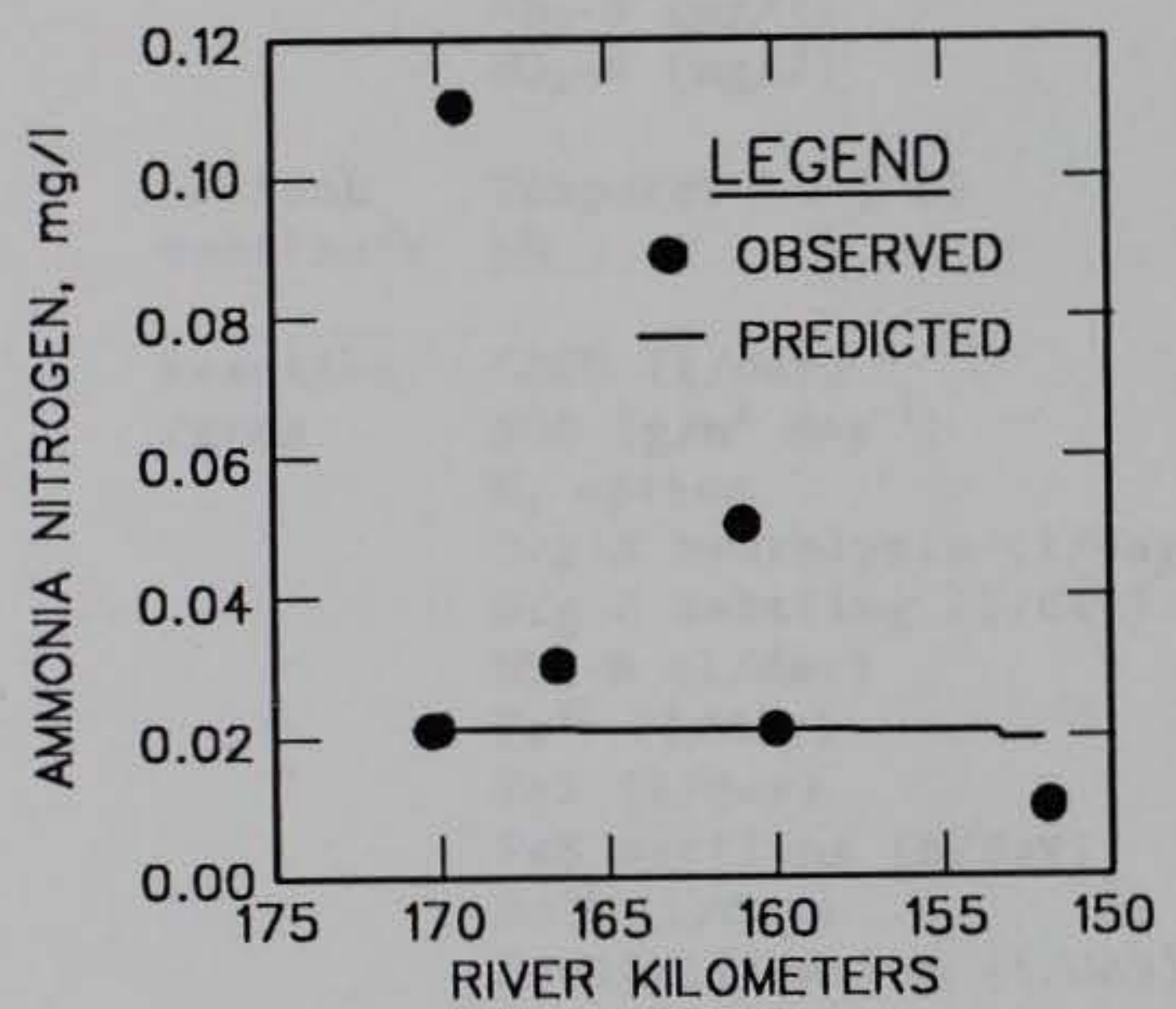

c. Ammonium nitrogen

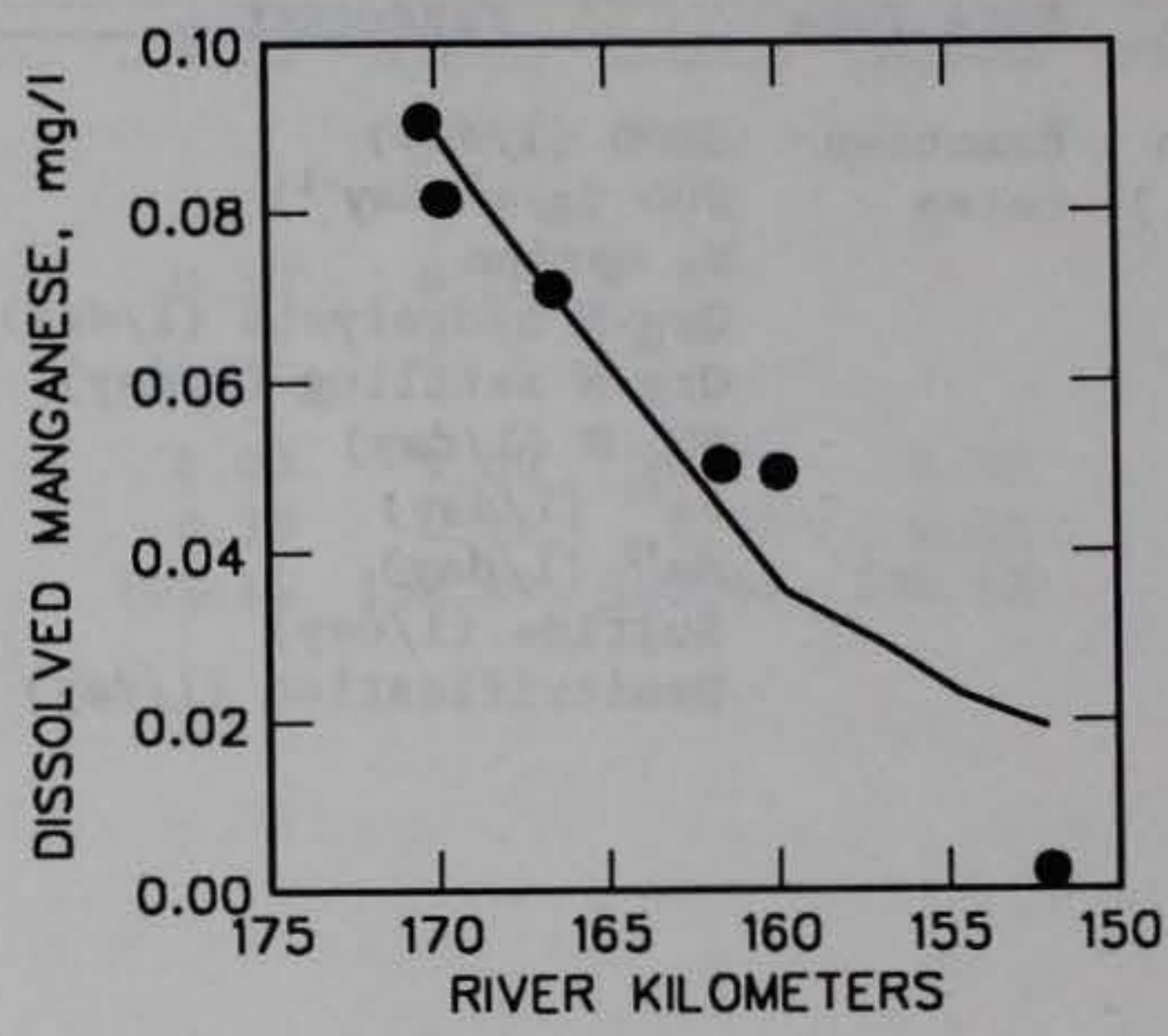

b. Dissolved manganese

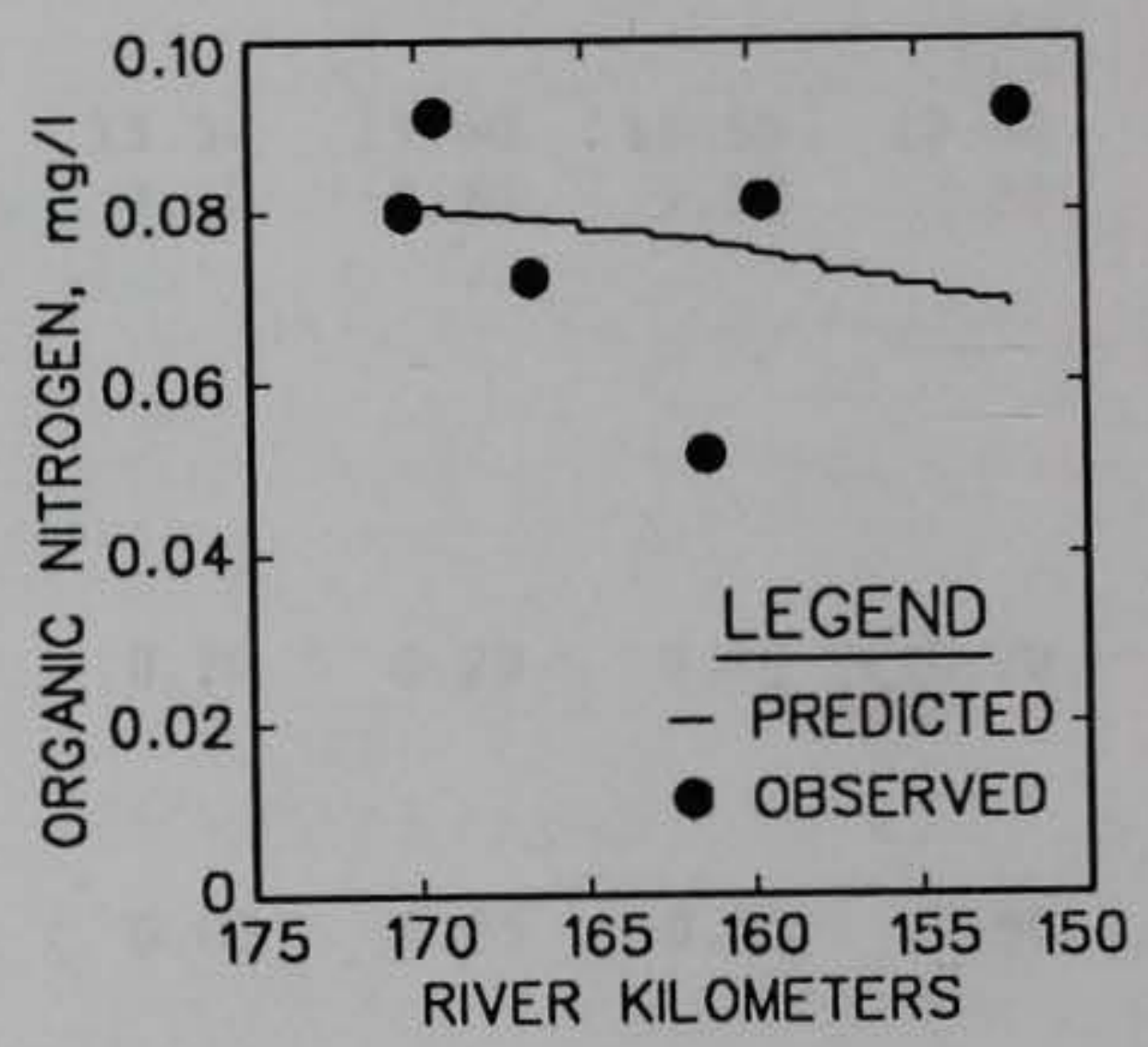

d. Organic nitrogen

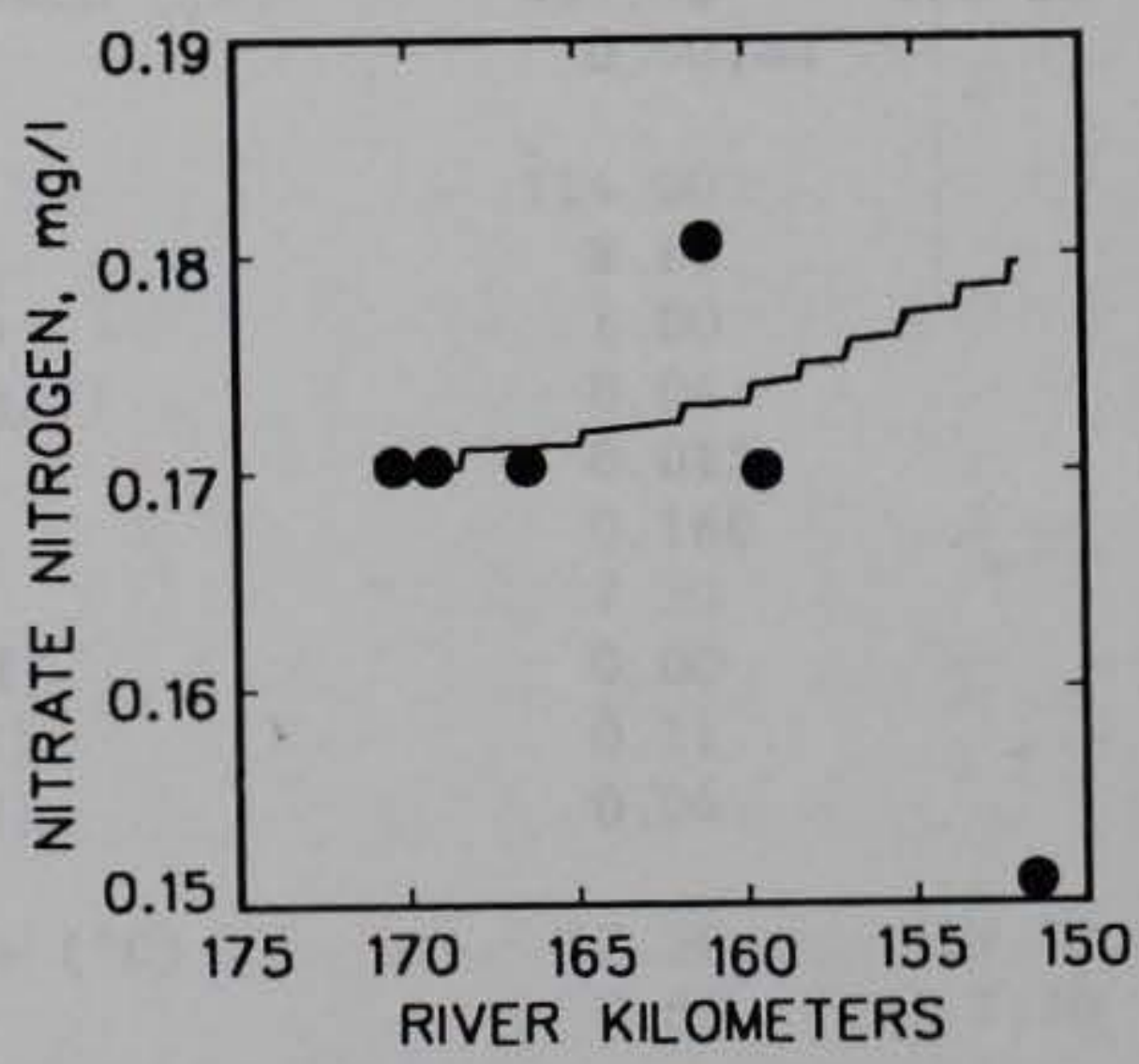

e. Nitrate nitrogen

Figure 7. Predicted and observed water quality, Greeson Dam tailwater 


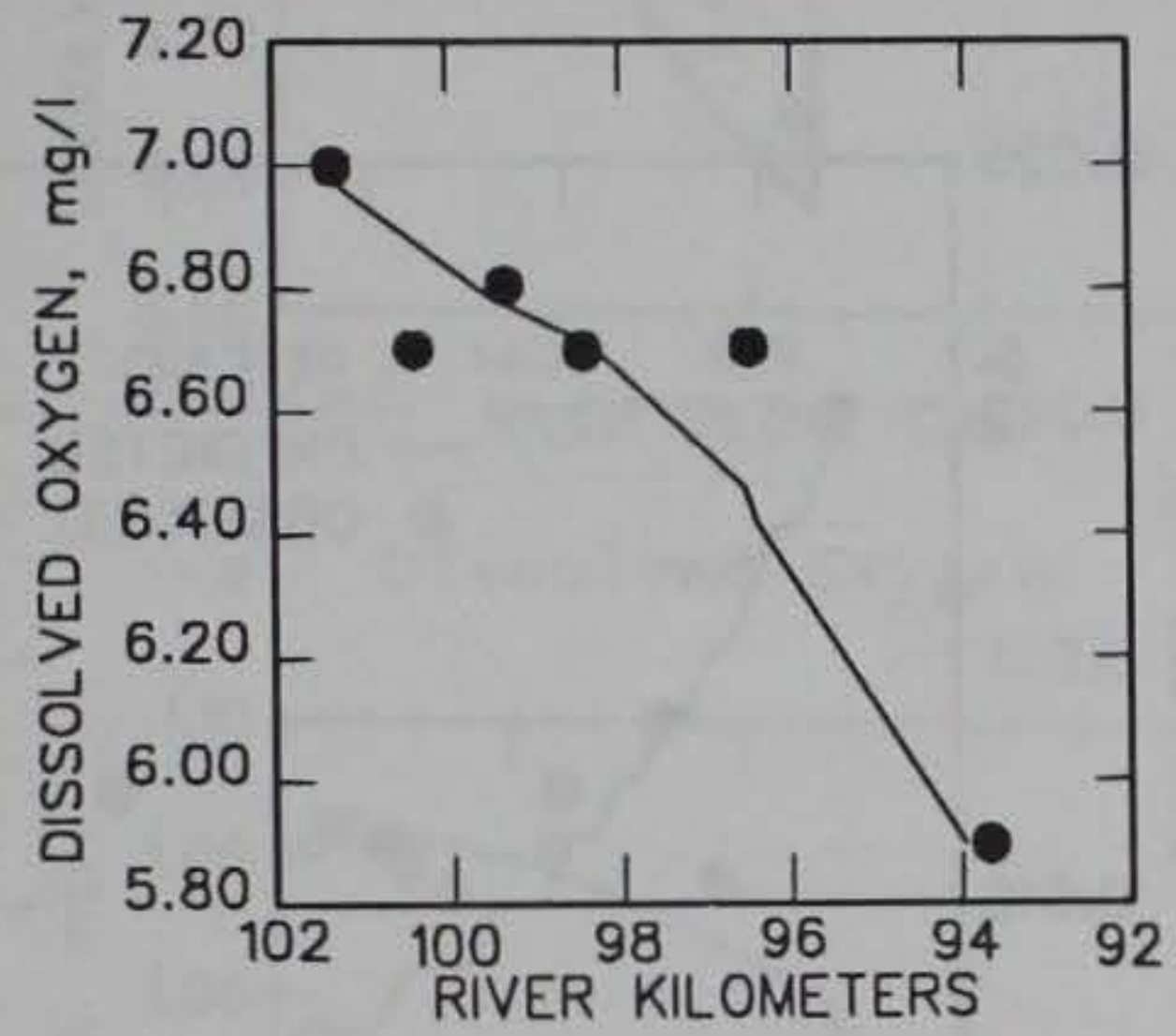

a. Dissolved oxygen

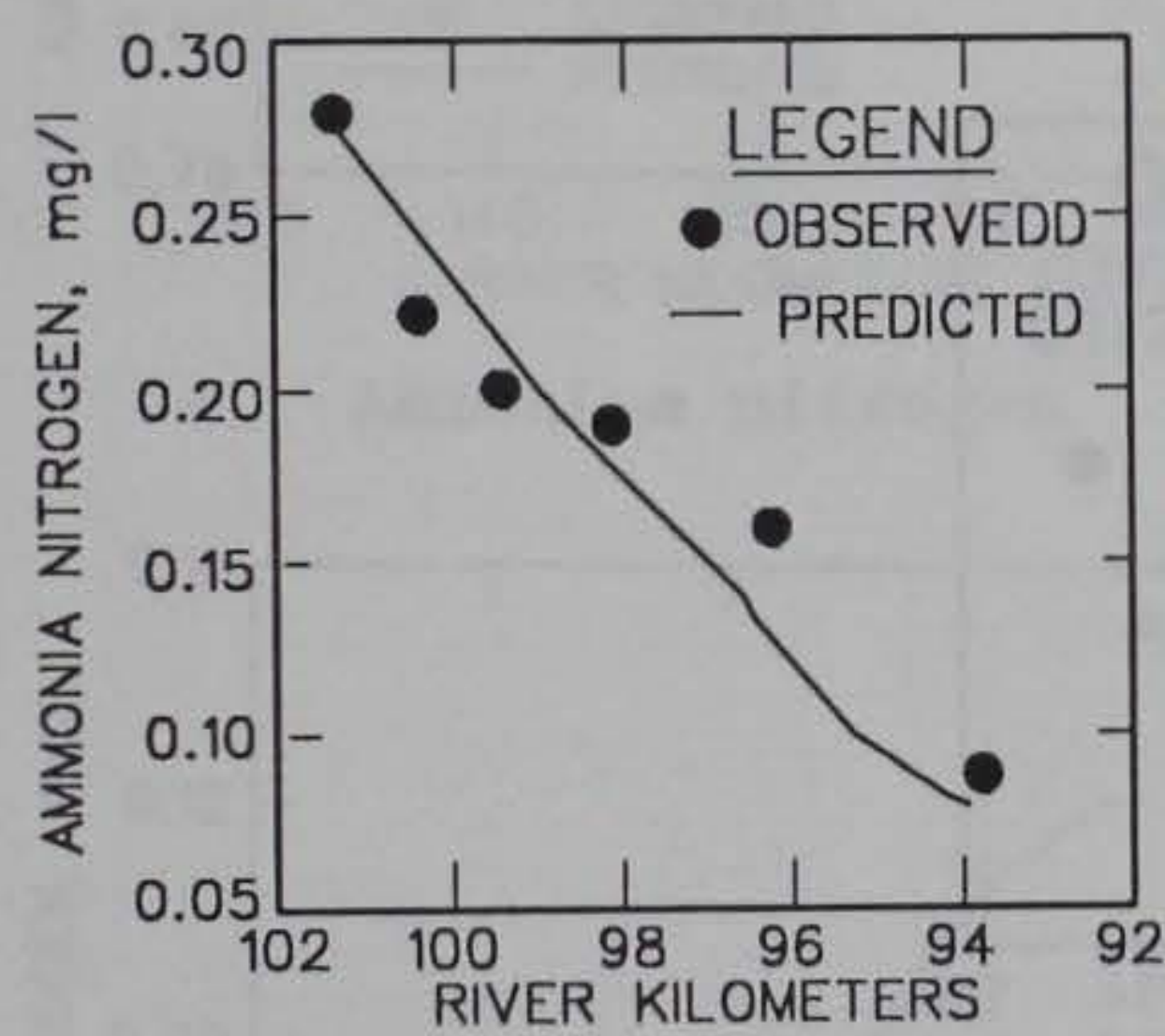

c. Ammonium nitrogen

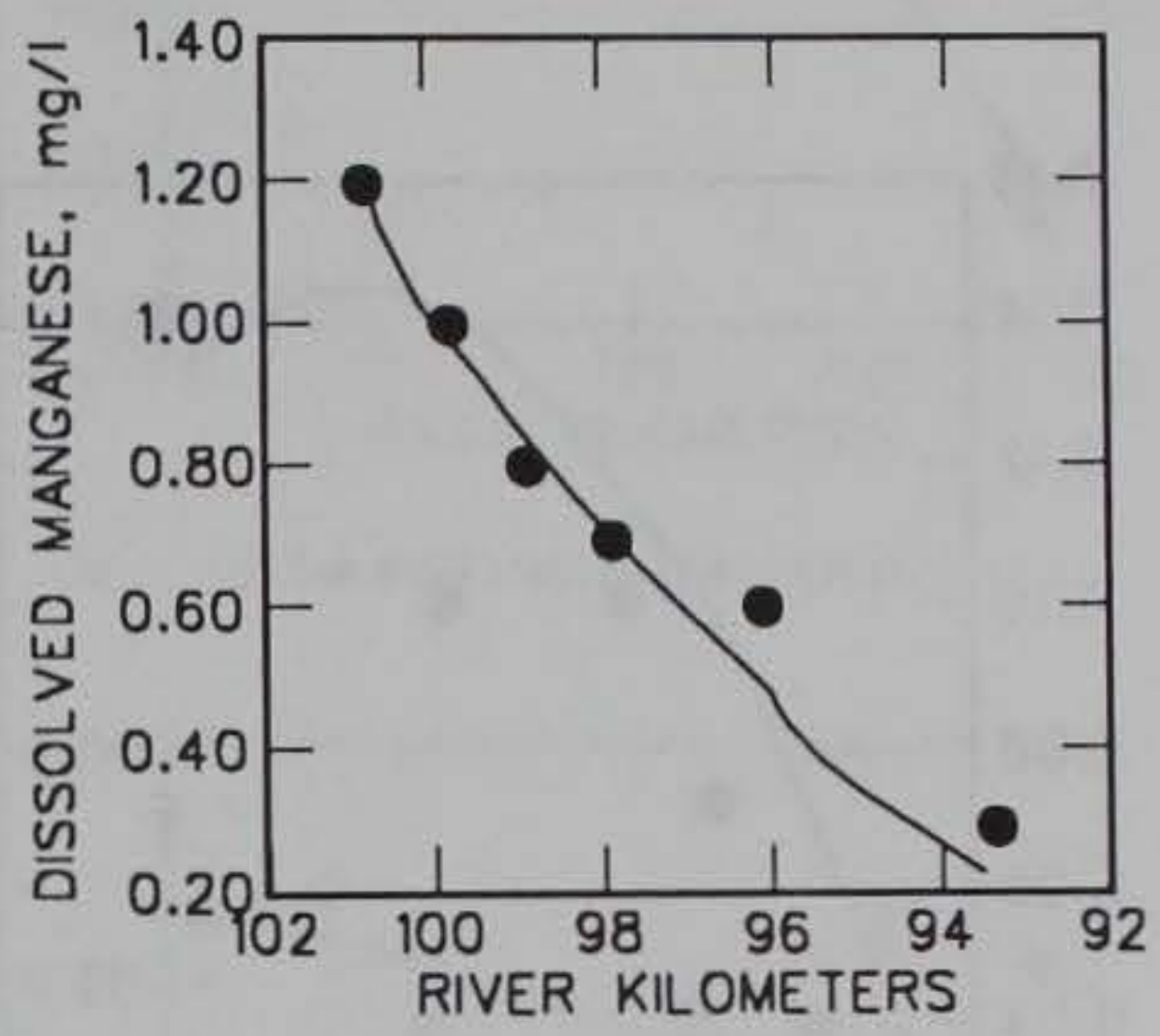

b. Dissolved manganese

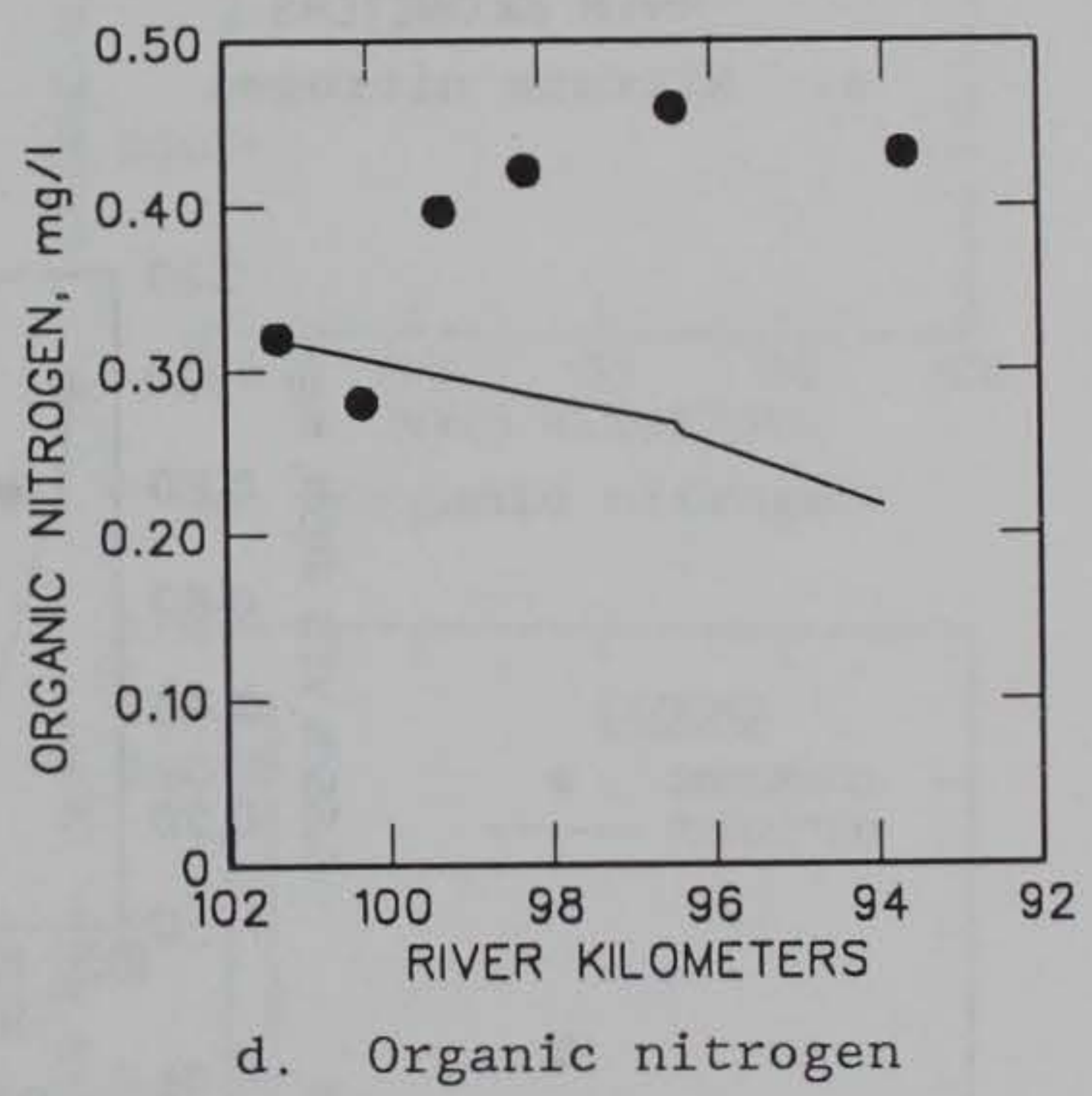

Figure 8. Predicted and observed water quality, Nimrod Dam tailwater (Continued) 

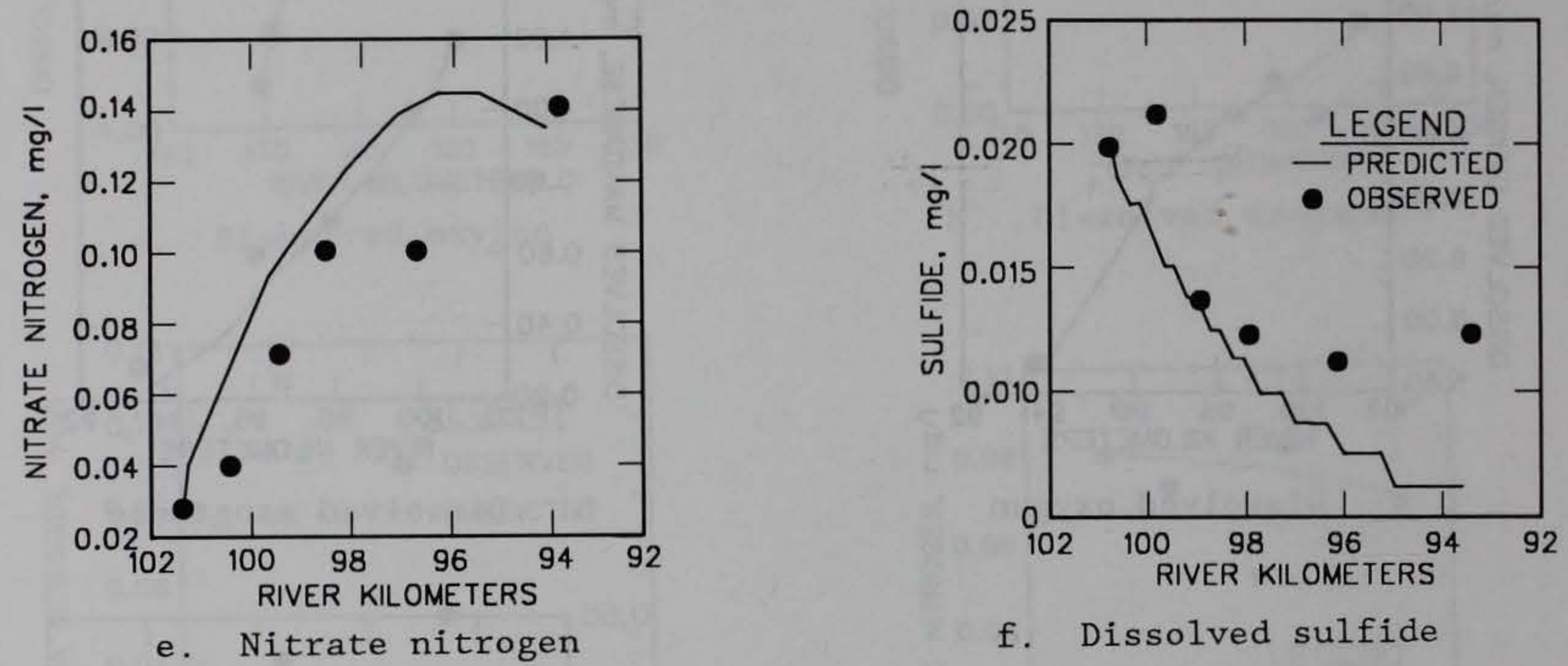

f. Dissolved sulfide

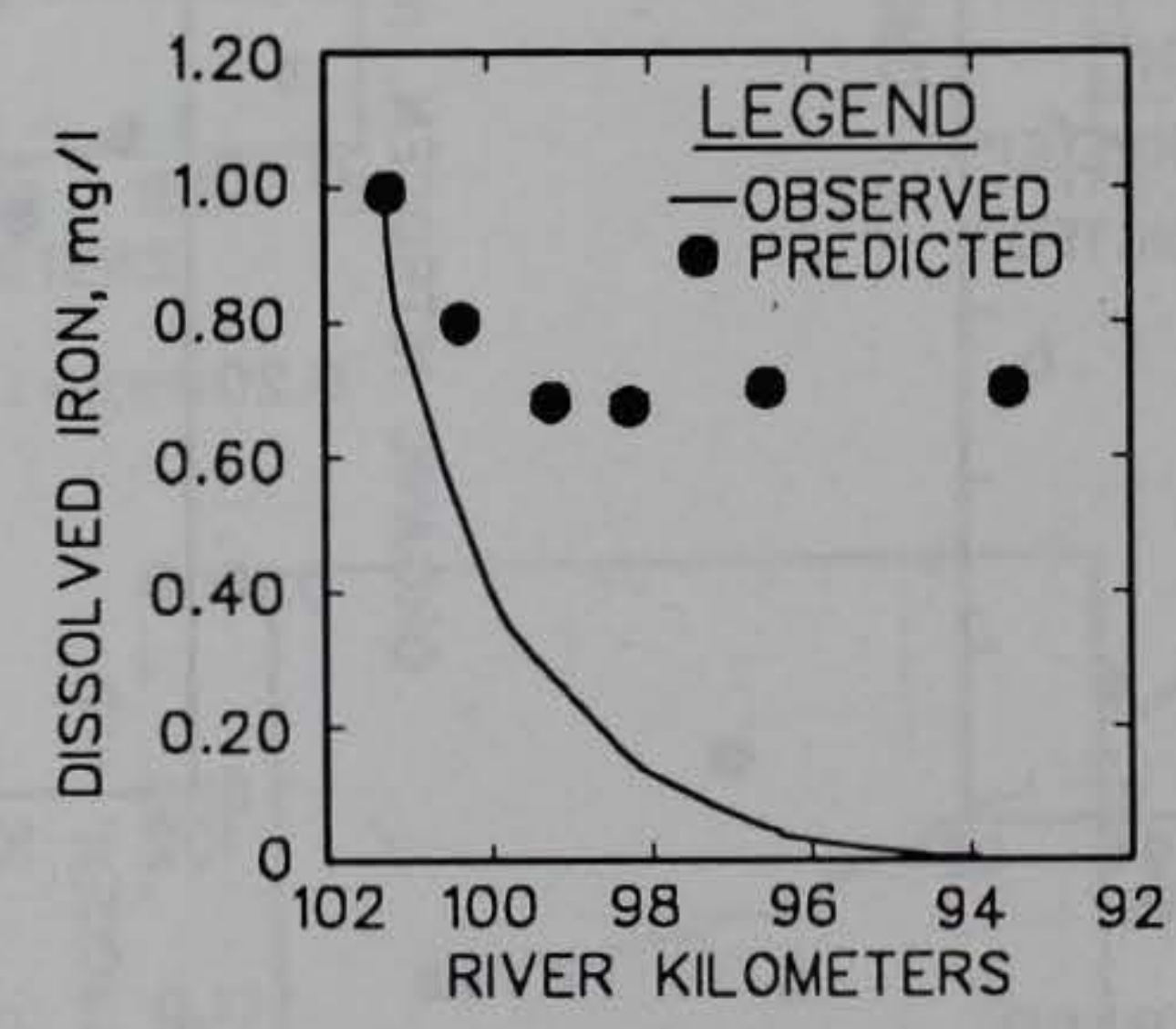

g. Dissolved iron

Figure 8. (Concluded) 


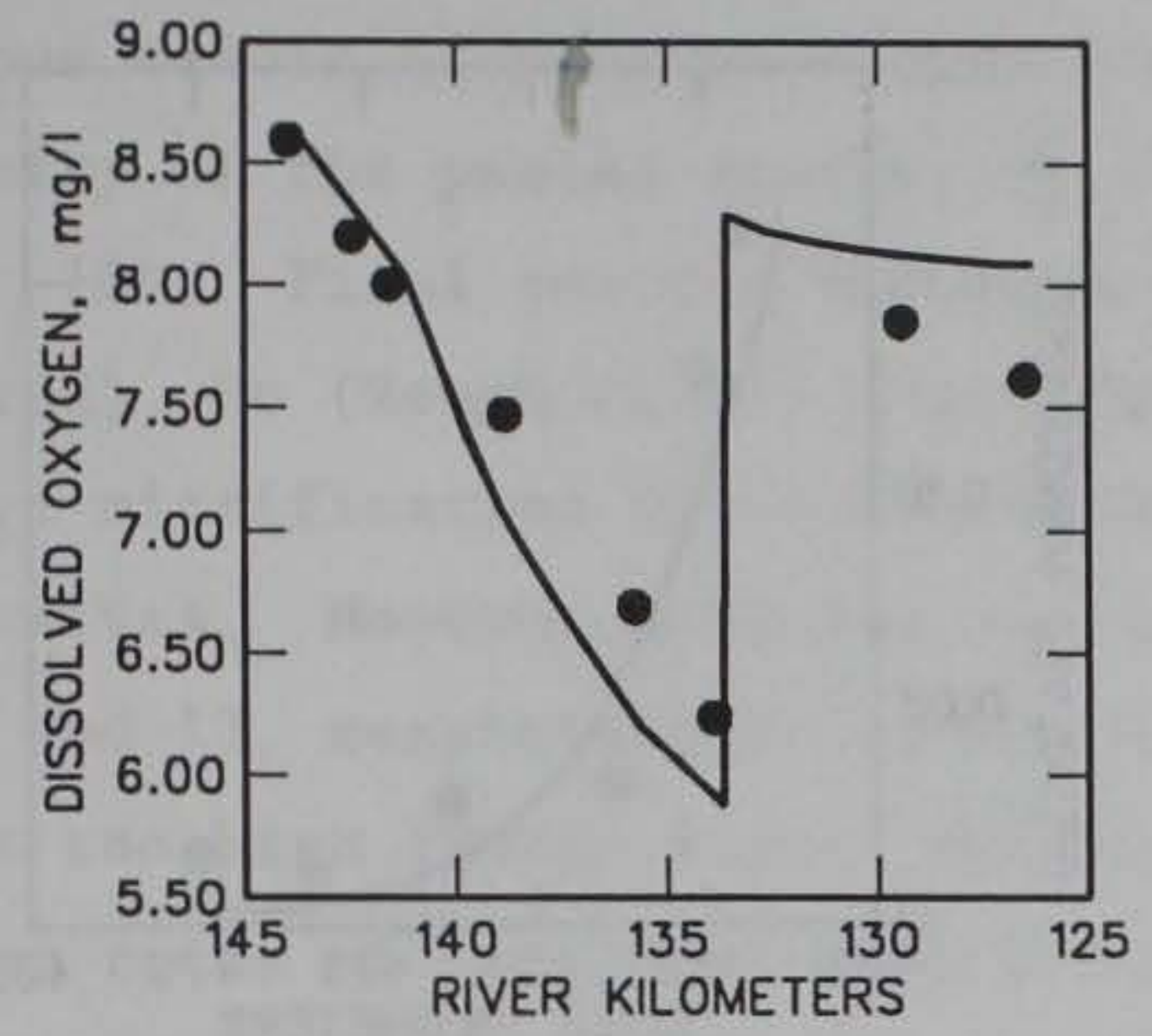

a. Dissolved oxygen

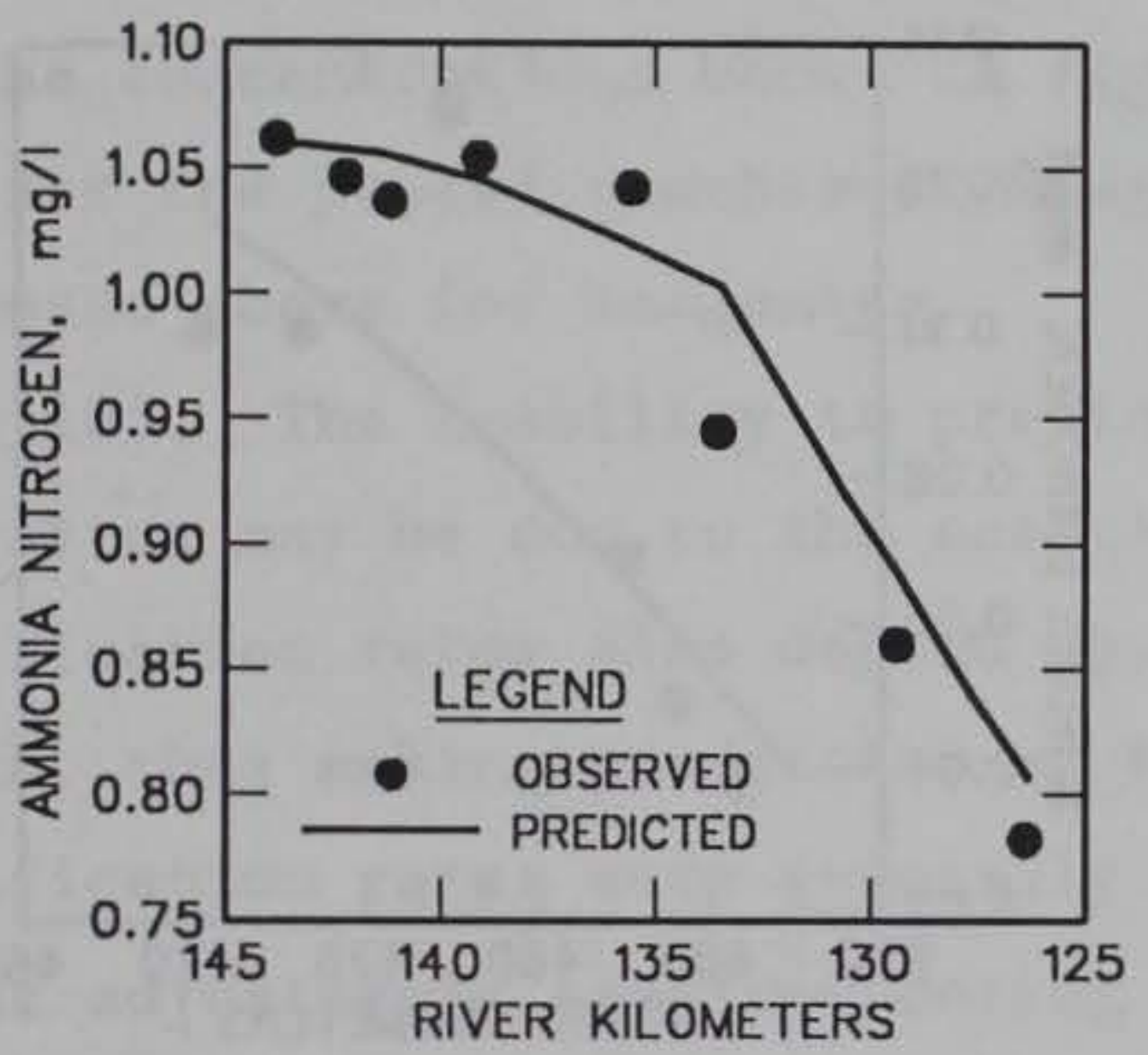

c. Ammonium nitrogen

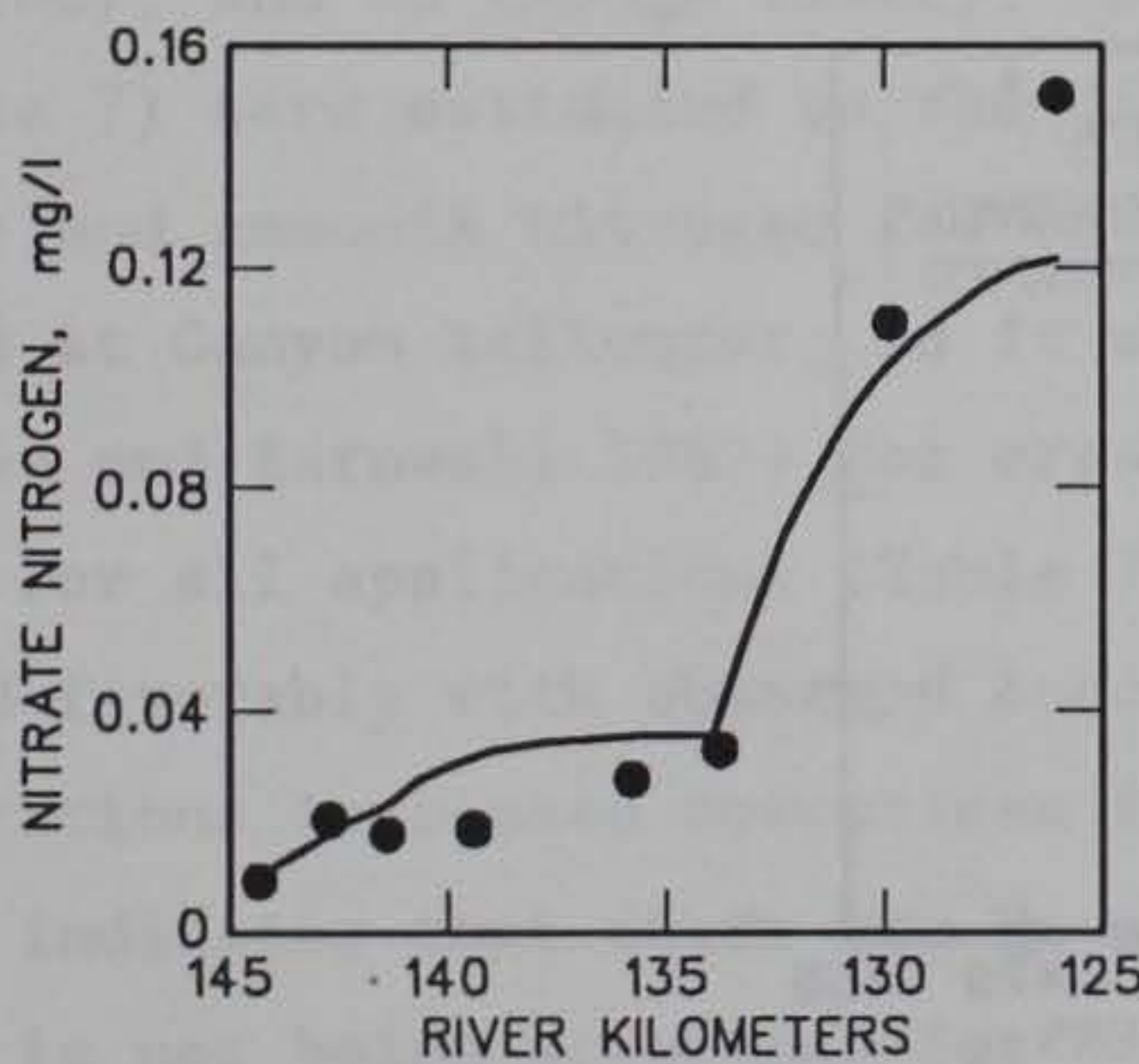

e. Nitrate nitrogen

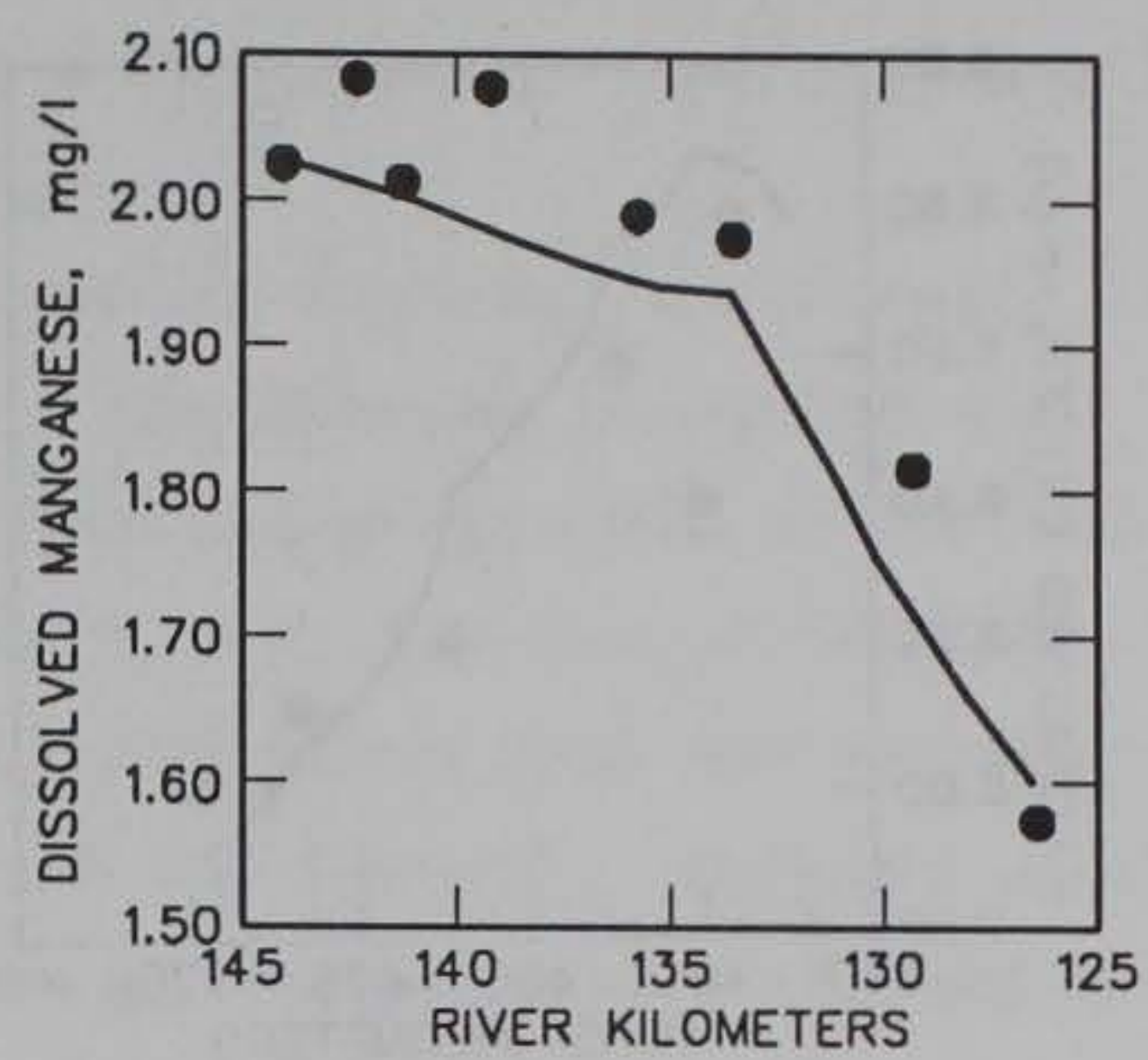

b. Dissolved manganese

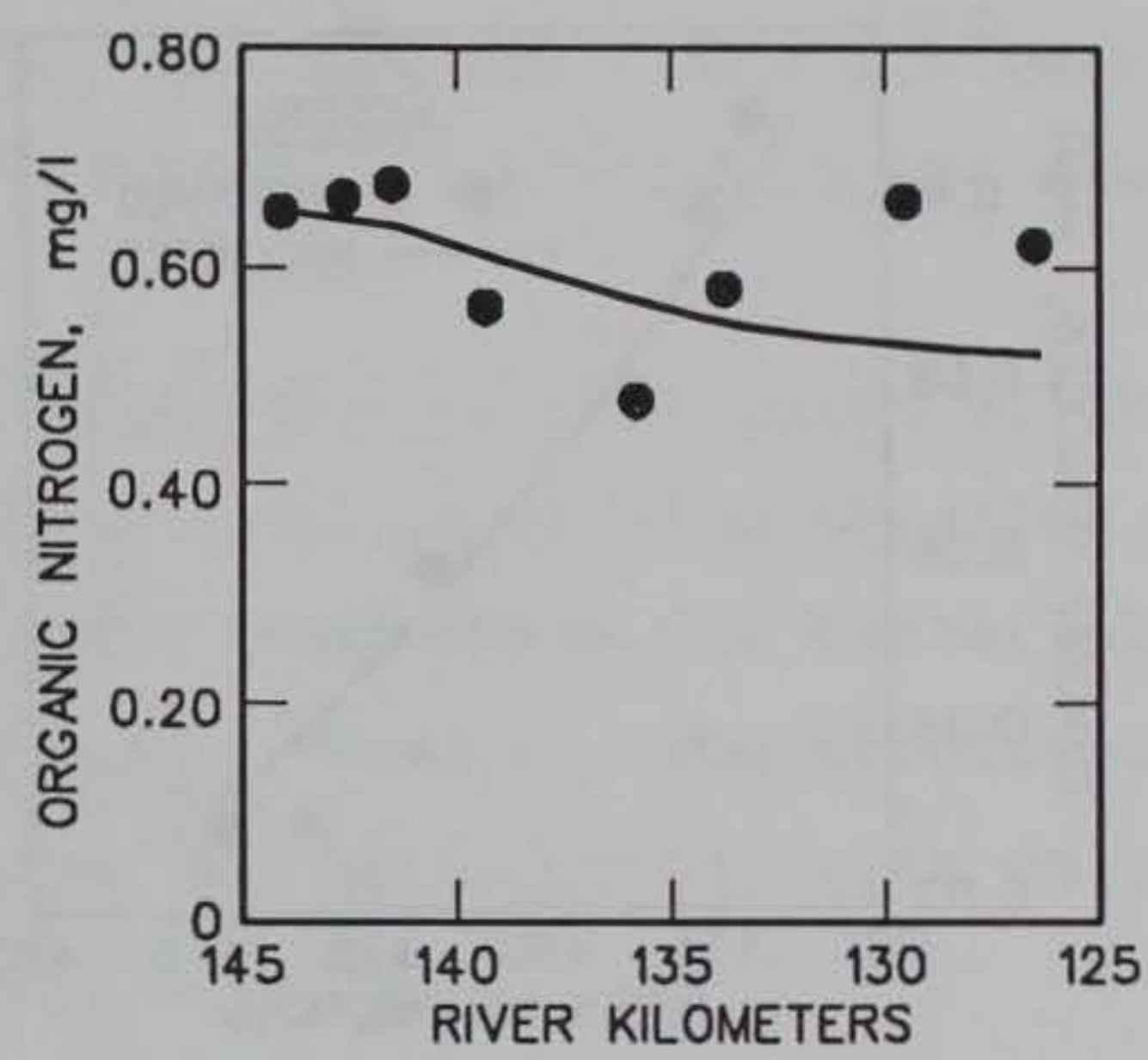

d. Organic nitrogen

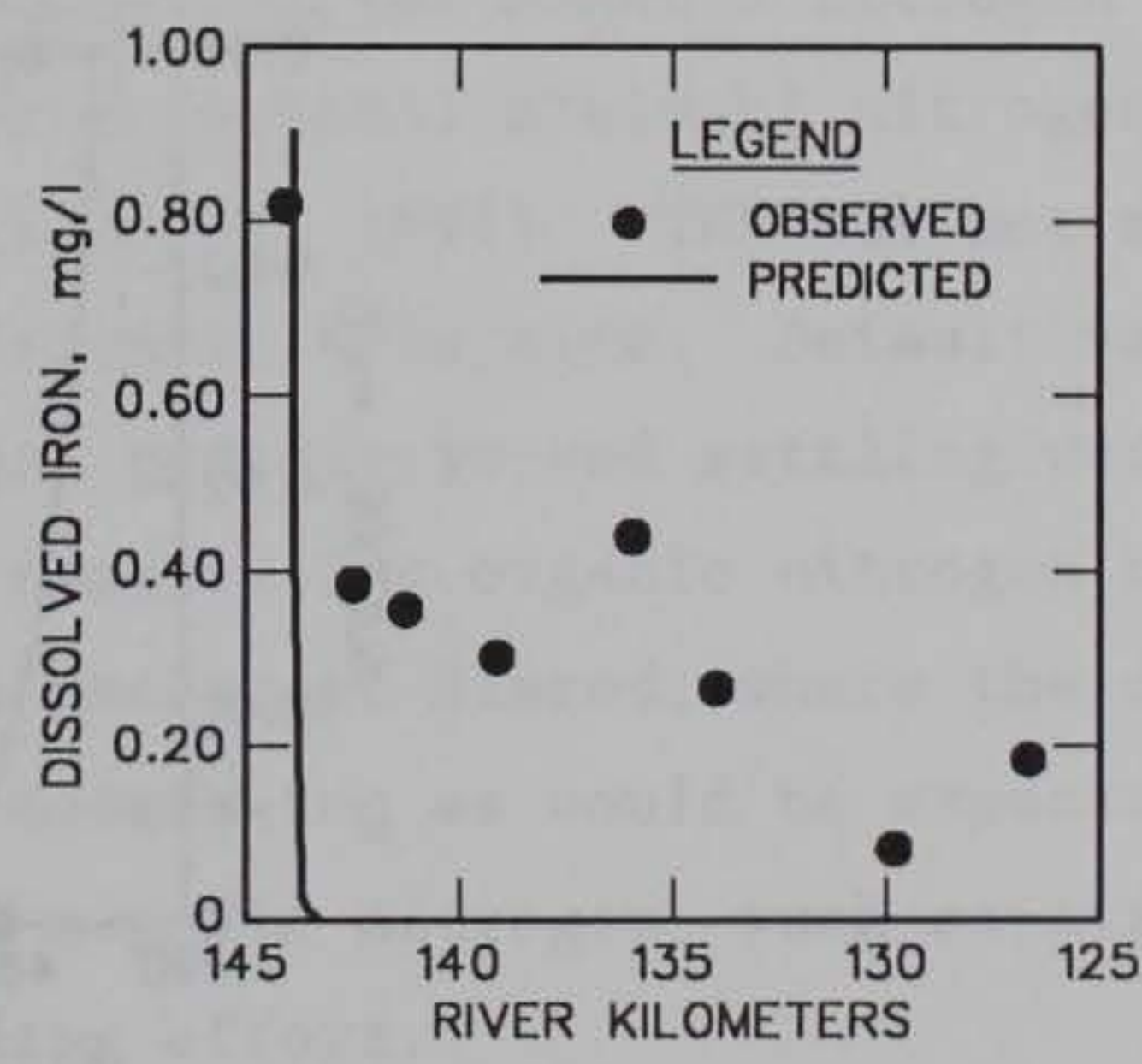

f. Dissolved iron

Figure 9. Predicted and observed water quality, Rough River tailwater 

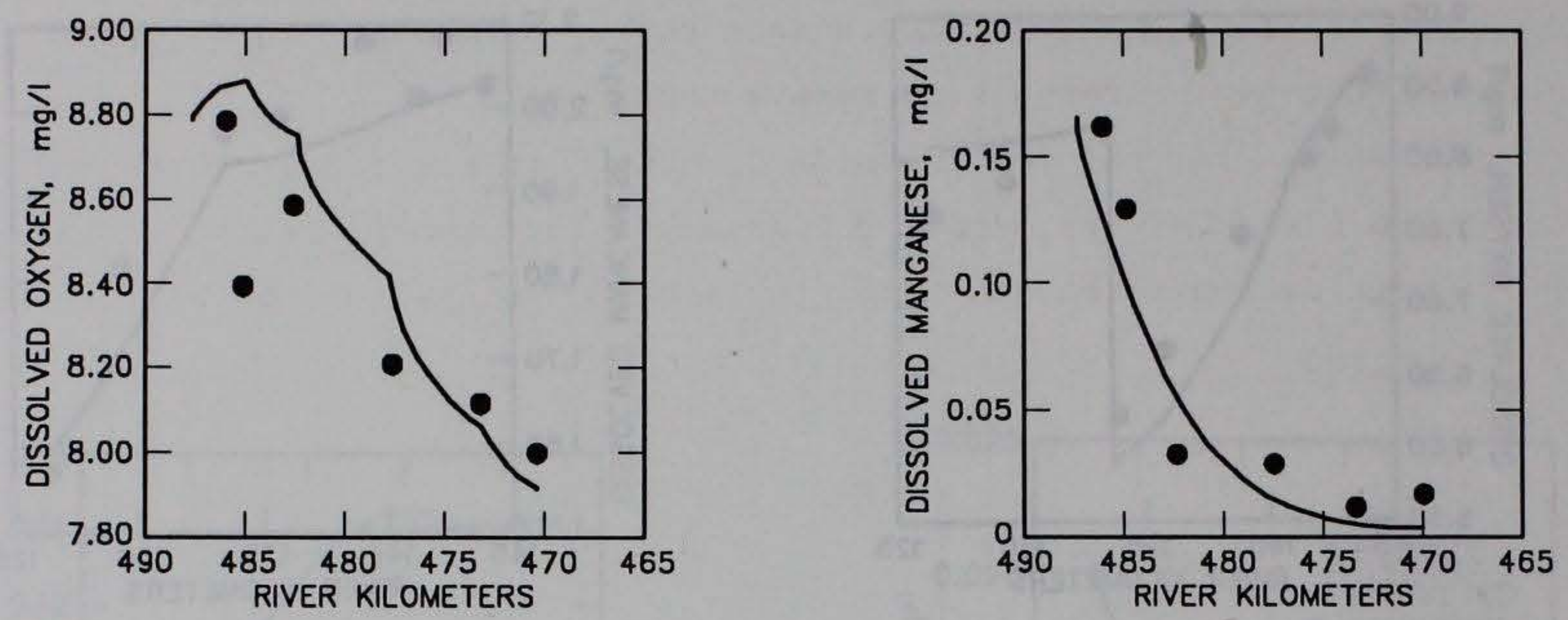

a. Dissolved oxygen

b. Dissolved manganese
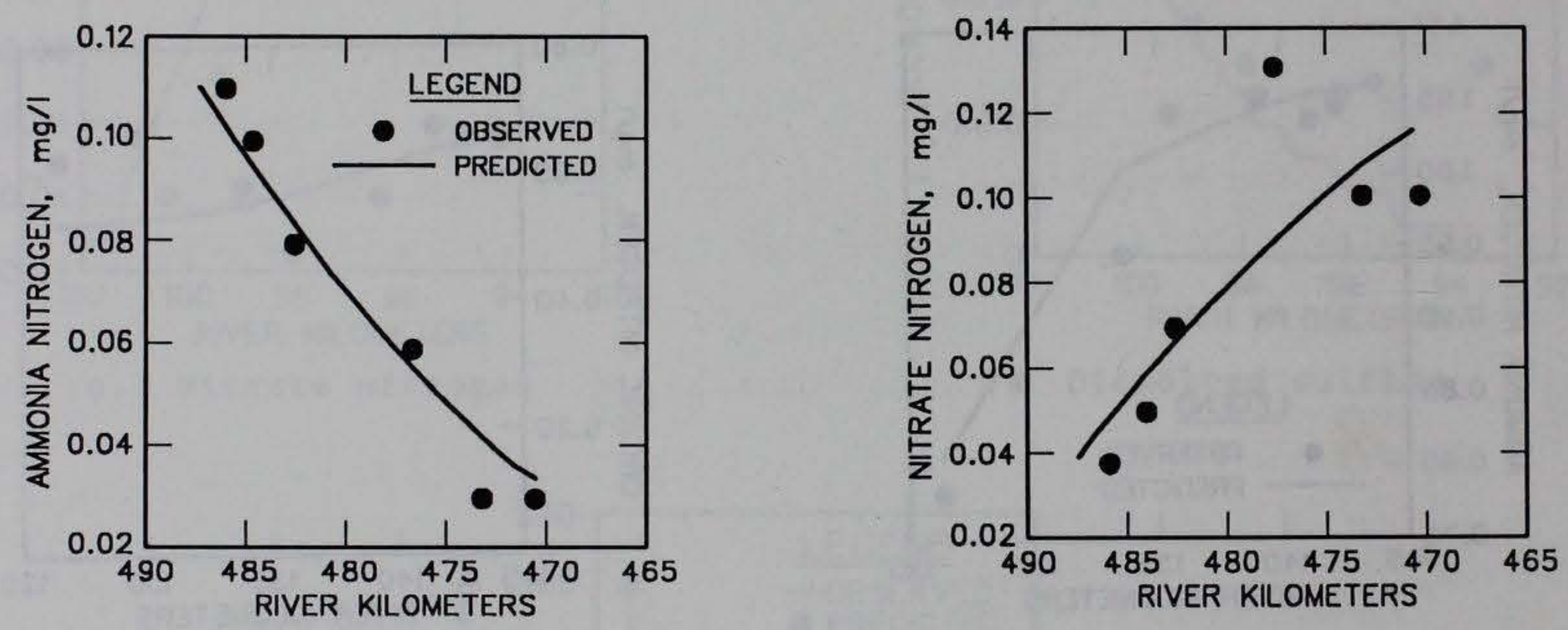

c. Ammonium nitrogen

d. Nitrate nitrogen

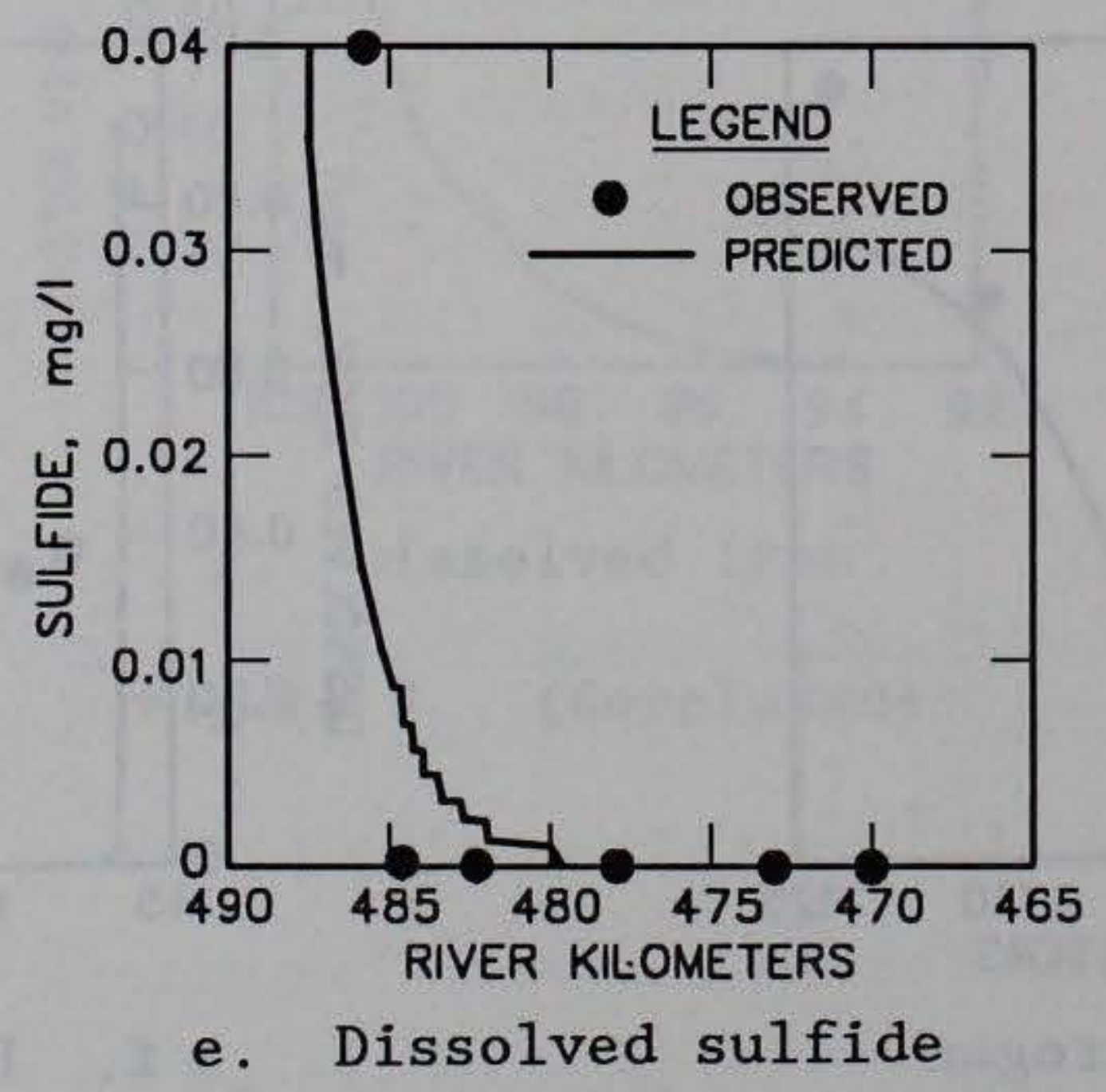

Figure 10. Predicted and observed water quality, Canyon Dam tailwater 
manganese), from being reaerated through the air-water interface. For these conditions, it seems reasonable to expect that there is less opportunity for hydrous oxides of manganese to accumulate on the substrate, thus lowering the capacity of the pooled reaches to remove manganese.

104. Final results for ammonium are shown in Figures 7c (Greeson), 8c (Nimrod), 9c (Rough River), and 10c (Canyon). The ammonia oxidation rate (i.e., nitrification rate) was initially modeled using Equation 27 for all four sites. However, results at Nimrod, Rough River, and Canyon (Figures 11a, $12 c$, and 13, respectively) showed that the nitrification rate was calculated to be too high (Rough River) or too low (Nimrod and Canyon). Modeled nitrification rates (i.e., Equation 27) were retained at the Greeson site, which had low concentrations (Figure 7c). The nitrification rates were calibrated against observed ammonia nitrogen data, yielding the rates shown in Table 7 and the concentrations shown in Figures $7 c, 8 c, 9 c$, and $10 c$. The low rates used for the pooled reaches of Rough River are probably related to the reasons discussed above for manganese.

105. The inability to predict the nitrification rate at three of the four sites may be due to the scatter in the data used to develop Equation 27. Nitrification rates also depend upon bacteria and conditions for bacterial growth, thus making prediction of rates difficult. However, the predicted nitrification rates were generally close to the calibrated rates with only slight adjustments required during calibration.

106. Results for organic nitrogen are shown in Figures 7d (Greeson), 8d (Nimrod), and 9d (Rough River). Boundary conditions for organic nitrogen (Table 7) were estimated as the difference between total Kjeldahl nitrogen (TKN) and ammonia nitrogen for each site (Nix et al. 1991). TKN was not measured at Canyon tailwater, so it was not modeled at this site. Default values (Brown and Barnwell 1987) for organic nitrogen hydrolysis and settling were used for all applications (Table 7). Final results for organic nitrogen compared favorably with observed concentrations except at Nimrod, where the concentrations increased downstream instead of decreasing as would be expected. This indicates that there may be a source of organic nitrogen, such as algae, that is not being accounted for in the modeling effort.

107. Results for nitrate nitrogen are shown in Figures 7e (Greeson), 8e (Nimrod), 9e (Rough River), and 10d (Canyon). Initially, TWQM had no mechanism for denitrification, and the results for nitrate nitrogen did not compare favorably with observed values, especially at Rough River (see Figure 12d). 


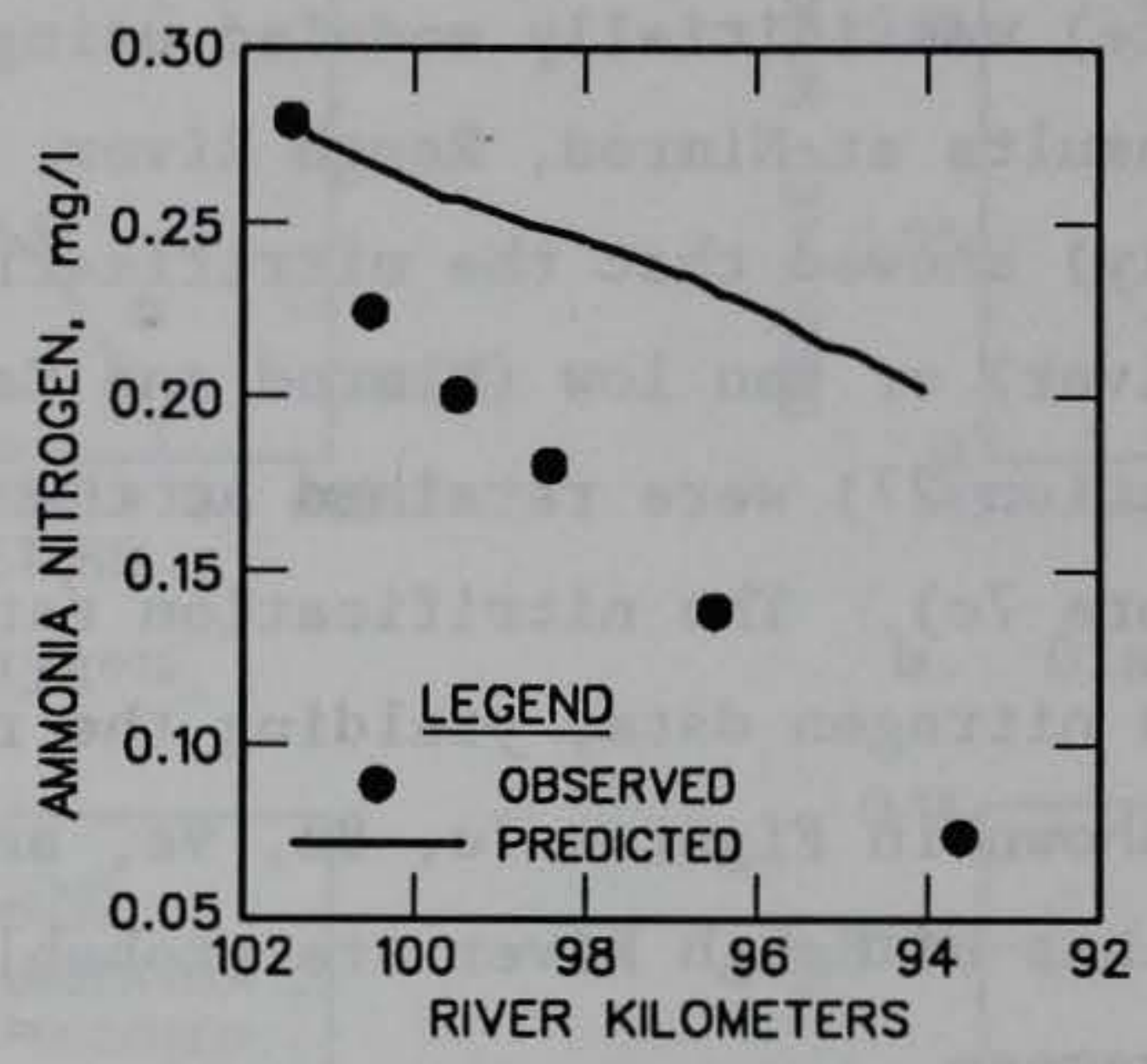

a. Ammonium nitrogen

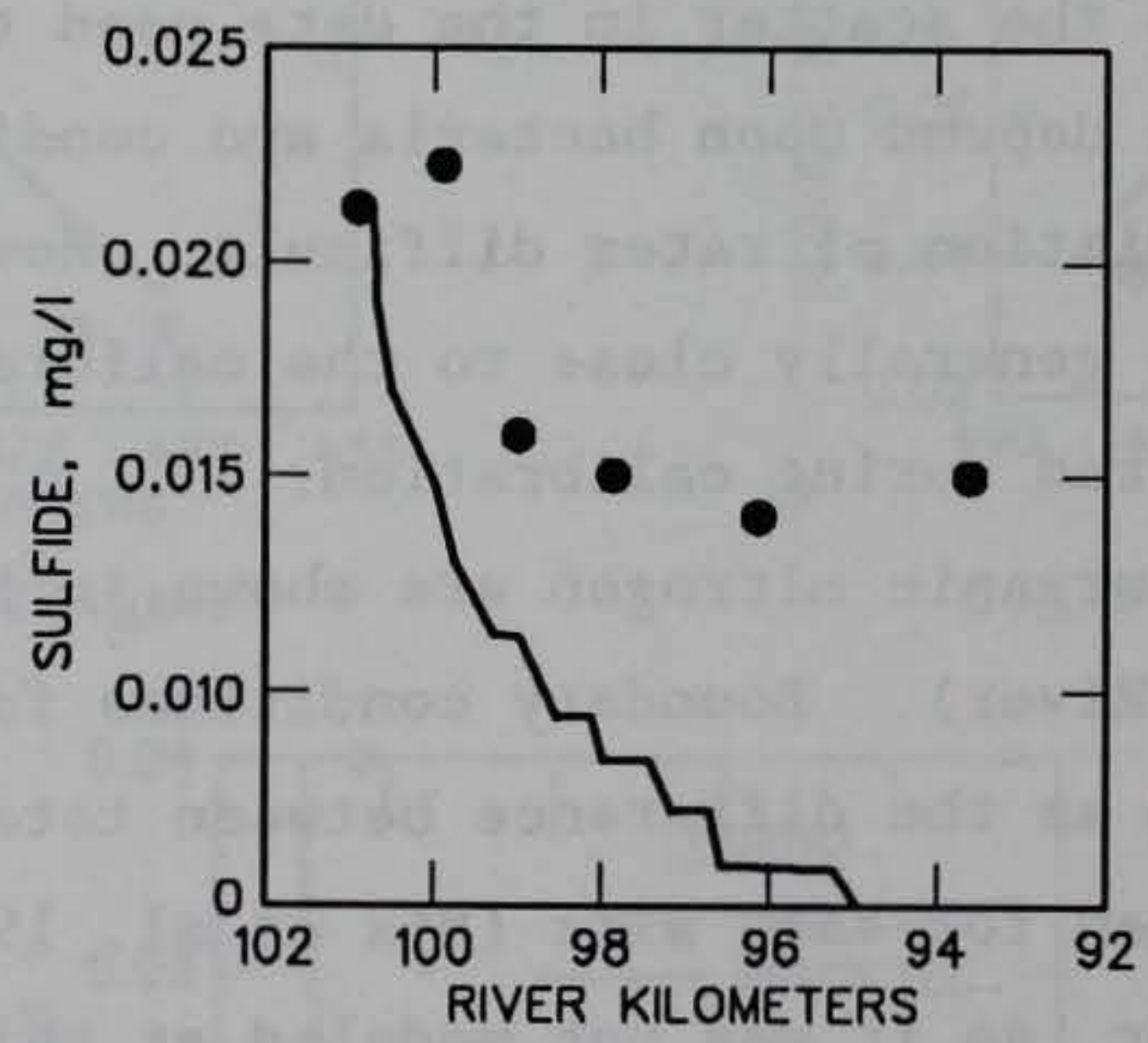

b. Dissolved sulfide

Figure 11. Initial predictions versus observed water quality, Nimrod Dam tailwater 


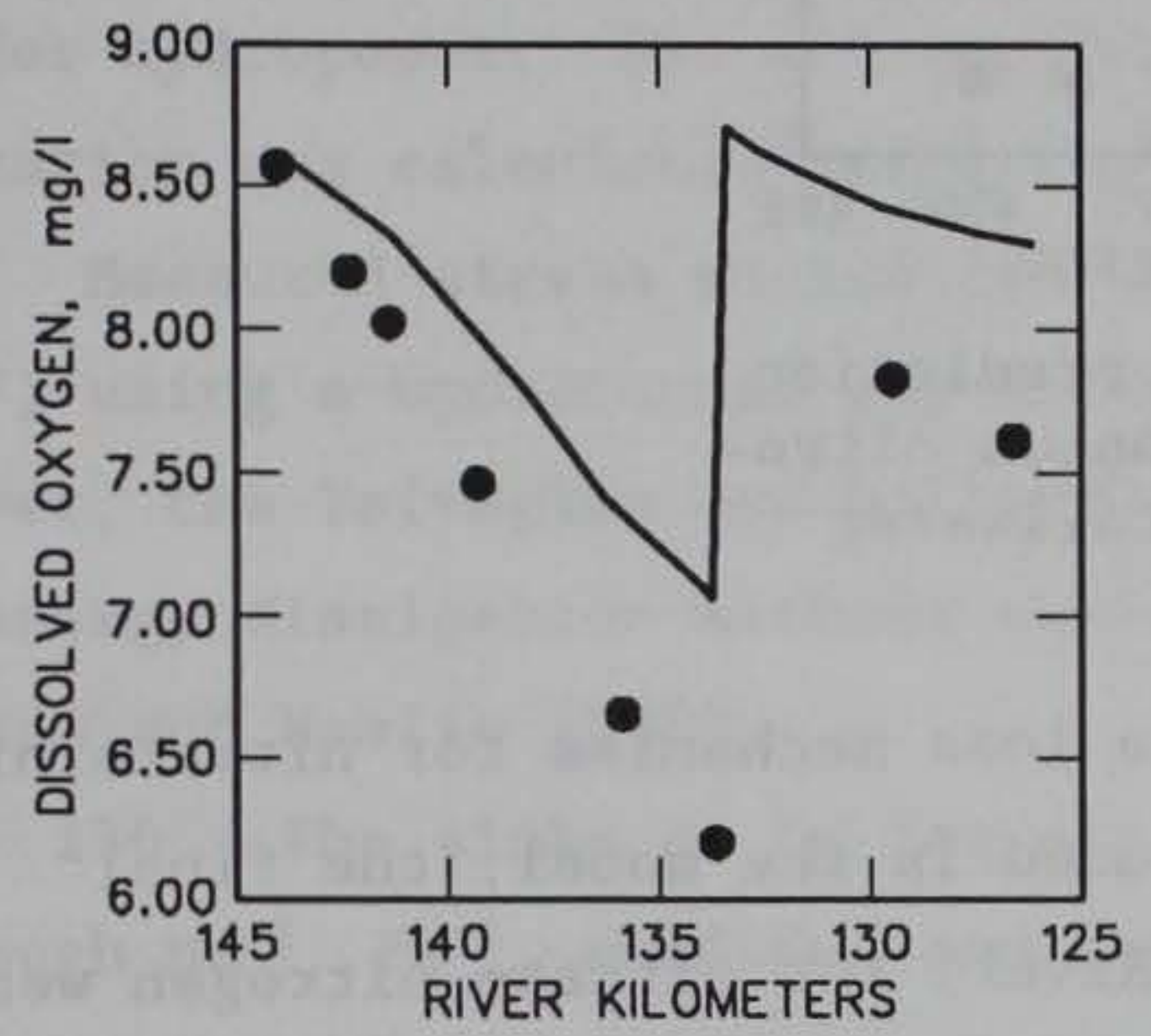

a. Dissolved oxygen

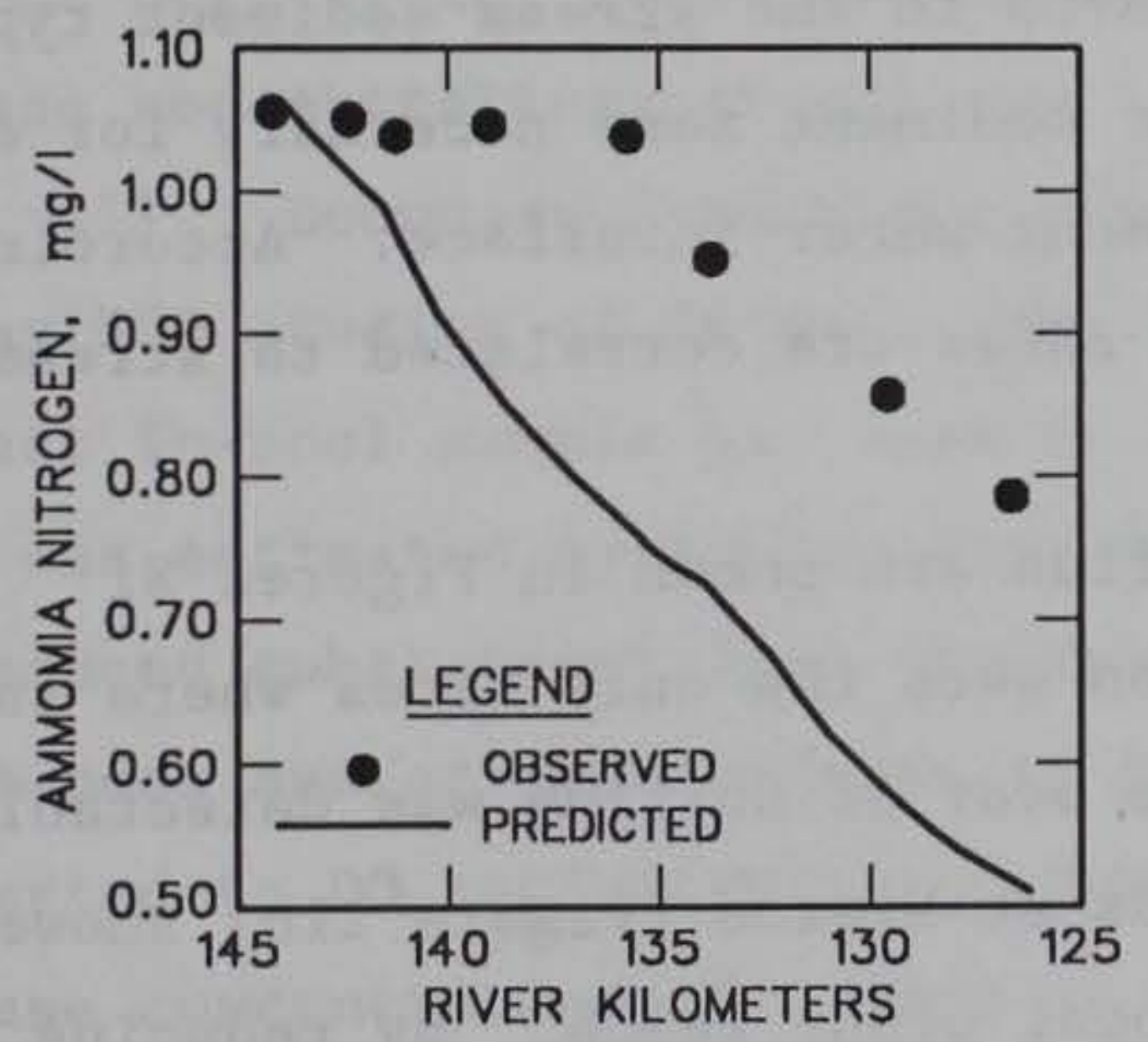

c. Ammonium nitrogen

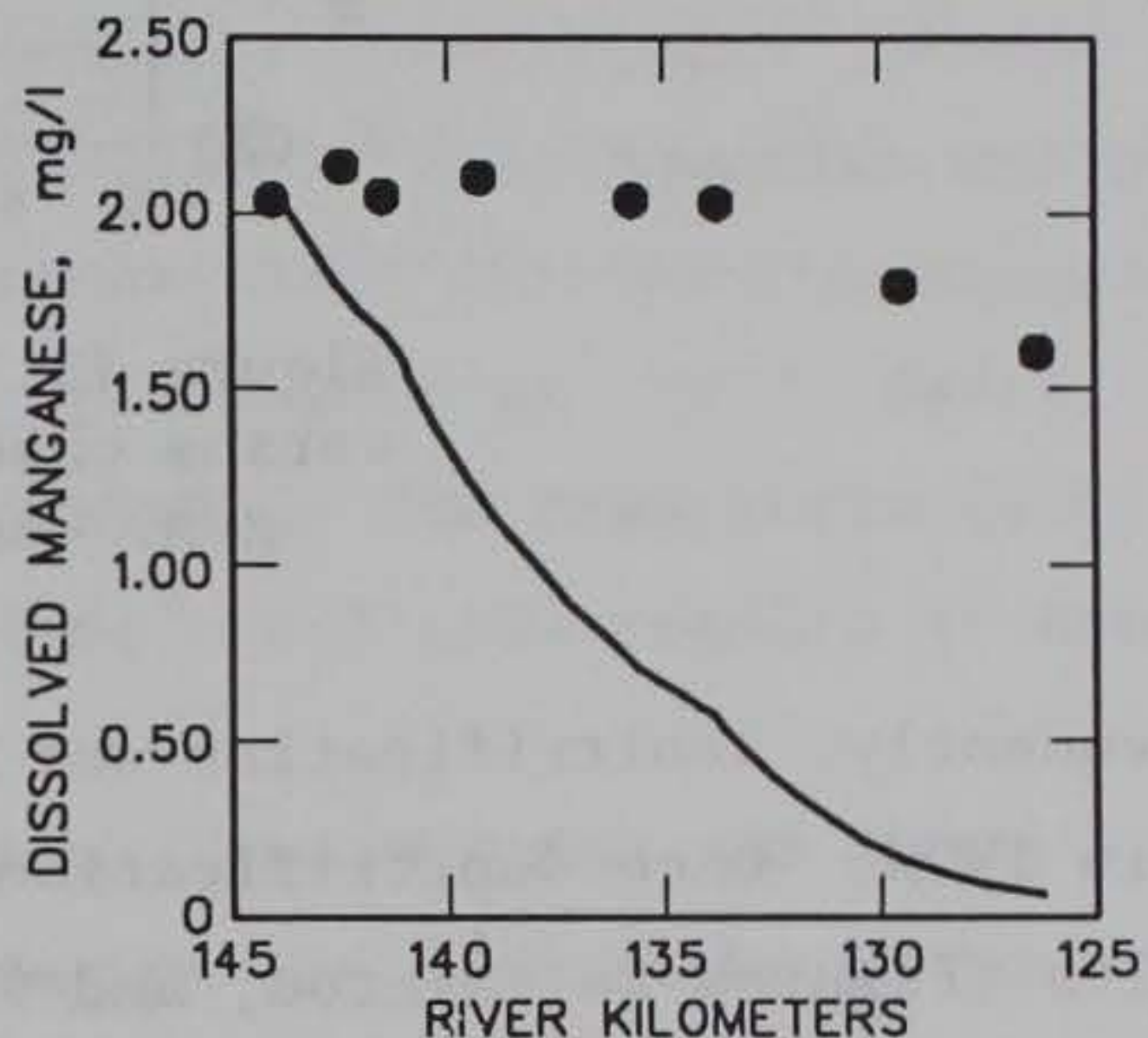

b. Dissolved manganese

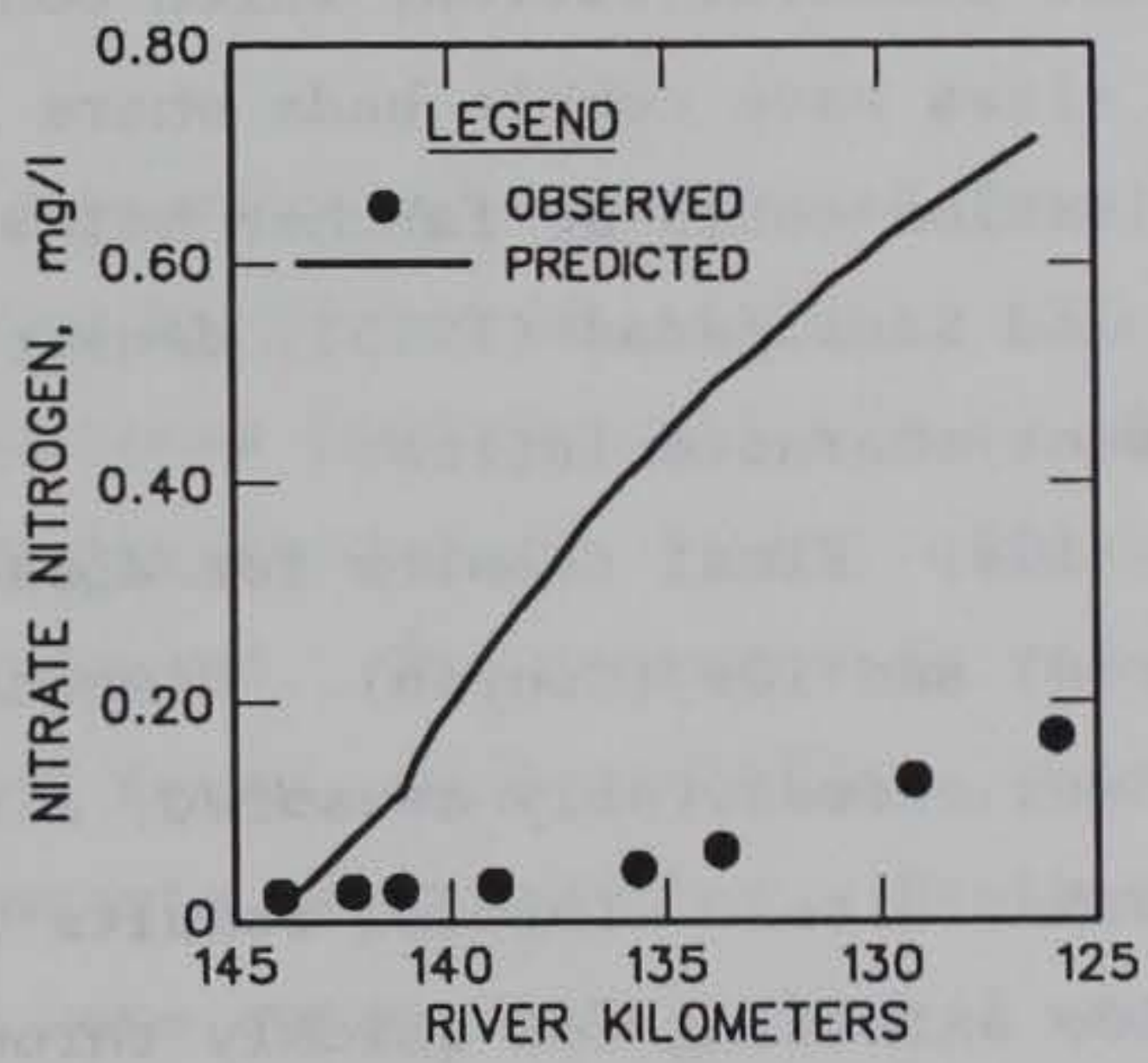

d. Nitrate nitrogen

Figure 12. Initial predictions versus observed water quality, Rough River tailwater 


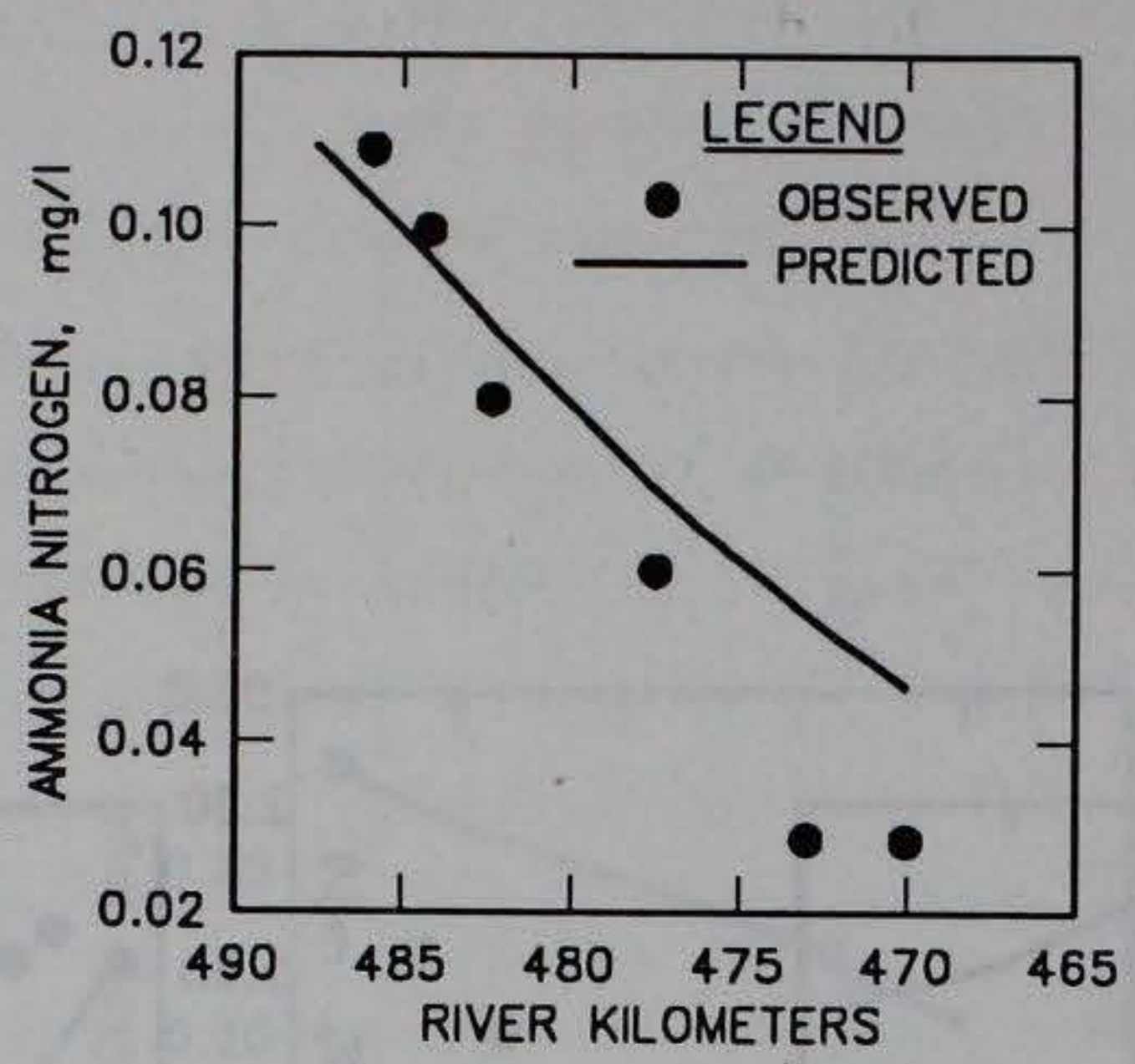

Figure 13. Initial prediction versus observed ammonium nitrogen, Canyon Dam tailwater

Consequently, denitrification was added as a loss mechanism for nitrate nitrogen in TWQM. Once denitrification was included in the model, the final results (Figures $8 \mathrm{e}$, Nimrod, and $9 \mathrm{e}$, Rough River) for nitrate nitrogen were improved from the initial applications. Greeson and Canyon tailwaters did not exhibit denitrification, which could be related to the stream sediment type. Both sites have cobble beds where the anoxic sediment zone necessary for denitrification could be farther below the sediment-water interface. According to Hill and Sanmugadas (1985), denitrification rates are correlated to streamsediment characteristics.

108. Final results for dissolved sulfide are shown in Figures $8 \mathrm{f}$ (Nimrod) and 10e (Canyon). Nimrod and Canyon were the only sites where sulfide was successfully measured, although the odor of sulfide was detectable at the other sites. Initial results for sulfide at Nimrod (Figure 11b) showed sulfide oxidizing too quickly through the model study reach. By reducing the sulfide oxidation rate more than an order of magnitude from the default value $\left(25\right.$ day $^{-1}$ ), a better comparison to the observed data was obtained (Figure $8 \mathrm{f}$ ). However, the predicted sulfide approaches zero concentration at the end of the study reach, while the observed data appear to remain at $0.01 \mathrm{mg} / \ell$. As mentioned in Part III, the data inferred that the oxidation rate of $\mathrm{HS}^{-}$at Nimrod was on the low side of reported ranges. Also, most of the sulfide for the $\mathrm{pH}$ conditions at Nimrod is $\mathrm{H}_{2} \mathrm{~S}$, which volatilizes. Adjustments to the reaeration rate $K_{2}$ may have improved sulfide predictions. Sulfide was measured at the first station at Canyon $(40 \mu \mathrm{g} / \mathrm{l})$ but declined to near zero at the other 
stations (Nix et al. 1991). The default value for sulfide oxidation was used at this site, and the results compared favorably with observed data (Figure 10e).

109. Final results for DO are shown in Figures $7 a$ (Greeson), $8 a$ (Nimrod), 9a (Rough River), and 10a (Canyon). The only model source of DO for each application was stream reaeration. Reaeration is especially high at the Greeson site (Figure 7a), where Do releases were low due to this site operating for hydropower. For all applications except the Greeson site, stream reaeration was calculated using the O'Connor-Dobbins (1958) equation option in TWQM. Measured stream reaeration rates at Greeson were obtained by Wilhelms (1987) using a hydrocarbon gas tracer method (Rathbun et al. 1977, 1978). However, the Tsivoglou and Wallace (1972) formulation for reaeration (i.e., the energy dissipation method) was also found to yield good results at Greeson (Dortch and Hamlin 1988).

110. The sinks of DO for all applications included SOD and CBOD. Although $\mathrm{Mn}^{+2}, \mathrm{Fe}^{+2}$, sulfide, and ammonia oxidation are also sinks of DO, they had little individual effect on Do concentrations, but their cumulative effect was not negligible. The low individual effects were due to the relatively low release concentrations at all the sites.

111. Boundary conditions for $C B O D$ measurements were estimated from the 10-day BOD studies of in-pool samples conducted by Nix et al. (1991). The deepest in-pool sample was used to estimate release CBOD for all sites. The CBOD was estimated by subtracting accountable oxygen demands (i.e., oxidation of reduced substances) from the total oxygen demand. The decrease in reduced substances and/or the increase in the oxidized forms, such as sulfate, was converted to DO equivalents through stoichiometric relationships. Estimated release concentrations for $\mathrm{CBOD}$ at all sites were approximately $1 \mathrm{mg} / \ell$ except Rough River, which was $2 \mathrm{mg} / \ell$. SOD rates were calibrated (Table 7) at Greeson and Canyon; measured SOD values (Nix et al. 1991) were used for Rough River and Nimrod. Zero SOD was used at the Greeson site for all reaches except the last reach due to the rocky, cobble substrate conditions. The last reach is characterized as a slower moving stream with silty substrate and a flatter slope; thus, SOD was specified in this reach.

112. With major sources and sinks of DO accounted for, all the predicted DO measurements compared favorably with the observed data except at Rough River (Figure 12a), where data indicated there may be another sink of DO not accounted for in the modeling effort. Based on examination of the total 
and dissolved iron measurements, the data indicated that FeS might be present, especially since sulfate increased in the downstream direction. Sulfate also increased with time in the 10-day BOD studies for Rough River. The decision was made to include $\mathrm{FeS}$ as a model variable at this site. The FeS boundary conditions were estimated as the difference between total and dissolved iron, yielding a value for $\mathrm{FeS}$ of $2.5 \mathrm{mg} / \mathrm{l}$. Final results of Rough River DO are shown in Figure $9 a$ and compare favorably with observed data. The reaeration through the mill dam is also evident in Figure 9a; this reaeration was modeled using the equation of Gameson (Brown and Barnwell 1987).

113. The other data sets were examined for the possible presence of FeS, but only the Nimrod site, in addition to Rough River, indicated the possible presence of $\mathrm{FeS}$. A substantial difference in total and dissolved iron occurred at Nimrod, which could be attributed to FeS. However, there was no increase in sulfate in the tailwater. If FeS was present, it must have oxidized rapidly as it passed through the release structure and the first $200 \mathrm{~m}$ of the tailwater.

114. Dissolved iron (i.e., $\mathrm{Fe}^{+2}$ ) was modeled for Nimrod and Rough River (Figures $8 \mathrm{~g}$ and $9 \mathrm{f}$, respectively); very little iron was detected at the Greeson and Canyon sites. The model shows reduced iron decreasing rapidly to values near zero, whereas the data indicate that dissolved iron decreases much more slowly and does not reach zero. Nimrod data actually indicate that dissolved iron does not decrease after traveling through the first few kilometers of tailwater. As discussed earlier, it is suspected that fine particulate iron passed through the filter, thus yielding an inaccurate measurement of dissolved iron. 
115. The studies reported herein were an attempt to obtain an improved understanding of water quality processes in reservoir tailwaters. The focus was on DO and the removal and/or oxidation of reduced substances (e.g., dissolved iron and manganese, sulfide, and ammonia) present in deep releases from anoxic reservoir strata. The intent of the analyses was to develop kinetic descriptions and rates for constructing a model of water quality in reservoir tailwaters. An attempt was made to develop relationships to predict kinetic rate coefficients based on ambient stream conditions.

116. Much information was gained from the dissolved manganese and ammonia data collected in this study. It was possible to develop relationships to predict the removal rate of dissolved manganese through adsorption onto the streambed. These relationships are based on the type of streambed (i.e., sediment or cobble) and the stream hydraulic conditions, which affect the diffusive sublayer thickness and the bed/water column mass transfer rate. Similarly, a relationship for the nitrification rate was developed using stream hydraulic conditions. The predictive relationship for nitrification was not as strongly correlated to hydraulic conditions as the relationship for manganese removal. Both relationships were developed from results of four field study sites; thus, only through studies at other sites can the relationships be further improved.

117. Data limitations precluded the development and/or improvement of predictive relationships for reduced iron, sulfide, and iron sulfide oxidation rates. Methods for measuring reduced (i.e., dissolved) iron and dissolved sulfide were not adequate to accurately account for the oxidation and/or removal of these substances from the tailwater. Additionally, the data suggest that iron sulfide was present in the releases at several of the sites, further complicating the studies. A limited amount of data was used to assess existing equations for predicting iron and sulfide oxidation rates. These results, although far from conclusive, did suggest that existing rate equations could be used as a rough estimate for oxidation rates.

118. Future studies should further address the oxidation/removal kinetics of iron, sulfide, and iron sulfide. Proper methods for sampling, handling, and analysis must be prescribed to better quantify concentrations of ferrous and ferric iron and iron sulfide. For example, Nix et al. (1991) recommended that a $0.1-\mu$ (rather than $0.45-\mu$ ) filter be used to separate 
dissolved and particulate iron. The sulfide analysis technique of Hongzhang (1982), which was used during the latter stages of the field studies by Nix et al. (1991), shows much promise for measuring low concentrations of sulfide. A technique must be identified to distinguish the amount of particulate iron that is iron sulfide versus ferric iron. After prescribing improved sampling and analysis procedures, field studies similar to the ones reported in this study should be undertaken to yield information concerning kinetic rates. Laboratory kinetic rate studies would also greatly expedite the development of general predictive relationships for processes that are not dependent on stream substrate and hydraulics.

119. The results of the 10-day BOD studies (Nix et al. 1991) indicate that little of the oxygen demand of hypolimnetic water is caused by the decomposition of organic carbon. However, these results were not conclusive because of the analytical problems discussed above for iron and sulfide. If future studies are conducted to investigate iron and sulfide, 10-day BOD studies should be conducted to more accurately delineate any DO demand arising from organic carbon synthesis. These studies should be conducted with and without seeded bacteria. Some consideration should also be given to detecting methane and any associated DO demand.

120. The model developed in this work (TWQM) is considered to have performed well for DO, dissolved manganese, nitrogen species, and dissolved sulfide. The relationships for predicting dissolved manganese removal rates are considered to be applicable for tailwaters that have experienced deep releases containing reduced manganese. For sites that do not have such releases but are considering a deep release (such as opening a bottom sluice that is rarely used), it may take some time (on the order of weeks) for the tailwater to acclimate and form a substrate that effectively sorbs dissolved manganese. The predictive equations for manganese removal do not account for any acclimation period.

121. Although the data for hydrogen sulfide were limited, the model should provide reasonable estimates since the formulations are based in part on volatilization, which is fairly well understood. Although the model contains simplistic algorithms for dissolved iron and iron sulfide, the lack of adequate field data prohibited the development of general relationships for kinetic rates or proper evaluation of model results. As discussed above, more work is required to better resolve the kinetics of dissolved iron and iron sulfide. 
122. It is recommended that future extensions of the model include the capability to predict $\mathrm{pH}$ changes in the tailwater. This could be accomplished by building in $\mathrm{CO}_{2}$, alkalinity, and carbonate equilibria. The escape of $\mathrm{CO}_{2}$ through the air-water interface can be modeled like other gas exchange processes, such as reaeration and volatilization of $\mathrm{H}_{2} \mathrm{~S}$. As $\mathrm{CO}_{2}$ escapes, $\mathrm{pH}$ increases. Since $\mathrm{pH}$ affects other processes, such as the rate of oxidation of reduced iron, incorporating $\mathrm{pH}$ would advance the utility of the model. 


\section{REFERENCES}

American Public Health Association, American Water Works Association, and Water Pollution Control Federation. 1981. Standard Methods for the Examination of Water and Wastewater, 16th ed., Washington, DC.

Almgren, T., and Hagstrom, I. 1974. "The Oxidation Rate of Sulfide in Sea Water," Water Research, Vol 8, pp 395-400.

Avrahami, M., and Golding, R. M. 1968. Journal of the Chem. Society of America, pp 647-651.

Benefield, L. D., Judkins, J. F., and Weand, B. L. 1982. Process Chemistry for Water and Wastewater Treatment, Prentice-Hall, Englewood Cliffs, NJ.

Benton, D. J. 1987. "User Guide to TPLOT Generalized Plot Package" (Version 4.4), Norris, TN.

Berner, R. A. 1980. Early Diagenesis, A Theoretical Approach. Princeton University Press, Princeton, NJ.

Bohac, C. E., Boyd, J. W., Harshbarger, E. D., and Lewis, A. R. 1983. "Techniques for Reaeration of Hydropower Releases, " Technical Report E-83-5, US Army Engineer Waterways Experiment Station, Vicksburg, MS.

Boudreau, B. P., and Guinasso, N. L., Jr., 1982. "The Influence of a Diffusive Sublayer on Accretion, Dissolution, and Diagenesis at the Sea Floor, "The Dynamic Environment of the Ocean Floor, K. A. Fanning and F. T. Manheim, eds., Lexington Books, Lexington, MA.

Bowie, G. L., Mills, W. B., Porcella, D. B., Campbe11, C. L., Pagenkopf, J. R., Gretchen L. R., Johnson, K. M., Chan, P. W. H., Gherini, S. A., and Chamberlin, C. E. 1985. "Rates, Constants, and Kinetics Formulations in Surface Water Quality Modeling," 2d ed., EPA/600/3-85/040, US Environmental Protection Agency, Athens, GA.

Brown, L. C., and Barnwe11, T. 0. 1987. "The Enhanced Stream Water Quality Models QUAL2E and QUAL2E-UNCAS: Documentation and User Manual, " EPA/600/387/007, US Environmental Protection Agency, Athens, GA.

Chen, K. Y., and Morris, J. C. 1972a. "Oxidation of Aqueous Sulfide by $\mathrm{O}_{2}$; 1. General Characteristics and Catalytic Influences," Advances in Water Pollution Control Research, S. H. Jenkins, ed., Pergamon Press, New York.

1972b. "Kinetics of Oxidation of Aqueous Sulfide by $\mathrm{O}_{2}$," Environmental Science and Technology. Vol 6, No. 6, pp 529-537.

Churchill, M. A., Elmore, H. L., and Buckingham, R. A. 1962. "The Prediction of Stream Reaeration Rates," International Journal of Air and Water Pollution. Vol 6, pp 467-504.

Connell, W. E. 1966. "The Reduction of Sulfate to Sulfide Under Anaerobic Soil Conditions," M.S. thesis, Louisiana State University, Baton Rouge, LA.

Davis, J. E., Holland, J. P., Schneider, M. L., and Wilhelms, S. C. 1987. "SELECT: A Numerical, One-Dimensional Model for Selective Withdrawal," Instruction Report E-87-2, US Army Engineer Waterways Experiment Station, Vicksburg, MS. 
Dortch, M. S., and Hamlin, D. E. 1988. "Research on Water Quality of Reservoir Tailwaters," WOTS Information Exchange Bulletin, Vol E-88-2, US Army Engineer Waterways Experiment Station, Vicksburg, MS.

Dortch, M. S., and Martin, J. L. 1989. "Water Quality Modeling of Regulated Streams," Alternatives in Regulated River Management, J. A. Gore and G. E. Petts, eds., CRC Press, Boca Raton, FL.

Fischer, H. B., List, E. J., Koh, R. C. Y., Imberger, J., and Brooks, N. H. 1979. Mixing in Inland and Coastal Waters, Academic Press, New York.

Golden Software, Inc. 1988. "GRAPHER Reference Manual," Golden, Co.

Gordon, J. A. 1983. "Iron, Manganese and Sulfide Mechanics in Streams and Lakes--A Literature Review," Report No. TTU-CE-83-2, Department of Civil Engineering, Tennessee Technical University, Cookeville, TN.

1989. "Manganese Oxidation Related to the Releases from Reservoirs," Water Resources Bulletin. Vol 25, No. 1, pp 187-192.

Gordon, J. A., Bonner, W. P., and Milligan, J. D. 1984. "Iron, Manganese and Sulfides Downstream from Normandy Dam," Lake and Reservoir Management, Report No. 440/5/84-001, US Environmental Protection Agency, pp 58-62.

Gordon, J. A. , and Burr, J. L. 1989. "Treatment of Manganese from Mining Seep Using Packed Columns," Journal of Environmental Engineering, Vol 115 , No. 2, pp 386-394.

Hatcher, K. J. 1986. "Sediment Oxygen Demand: Processes, Modeling, and Measurement," Institute of Natural Resources, University of Georgia, Athens, GA.

Hess, G. W. 1984. "A Transport Model of Manganese in Rivers," M. S. thesis, Georgia Institute of Technology, Atlanta, GA.

Hess, G. W., Byung, R. K., and Roberts, P. J. W. 1989. "A Manganese Oxidation Model for Rivers," Water Resources Bulletin. Vol 25, No. 2, pp 359-365.

Hill, A. R. 1979. "Denitrification in the Nitrogen Budget of a River Ecosystem," Nature, Vol 281, pp 291-292.

Hill, A. R., and Sanmugadas, K. 1985. "Denitrification Rates in Relation to Stream Sediment Characteristics," Water Research, Vol 19, No. 12, pp 15791586.

Hongzhang, W. 1982. "Visual Mercurimetric Titration Method for the Determination of Hydrogen Sulfide in Air and Water at ppb Levels," Chemical Abstracts, Vol 97, No. 202959h (translated from Chinese by Language Services, Knoxville, TN).

Hsiung, T. M. 1987. "Manganese Dynamics in the Richard B. Russell Impoundment," M.S. thesis, Clemson University, Clemson, SC.

Langbien, W. B., and Durum, W. H. 1967. "The Aeration Capacity of Steams," Circular 542, US Geological Survey, Washington, DC.

Lyman, W. J., Reeh1, W. F., and Rosenblatt, D. H. 1982. Handbook of Chemical Property Estimation Methods, McGraw-Hill, New York.

McCutcheon, S. C. 1989. Water Quality Modeling: Vol I. Transport and Surface Exchange in Rivers, R. H. French, ed., CRC Press, Boca Raton, FL.

Millero, F. J. 1986. "The Thermodynamics and Kinetics of the Hydrogen Sulfide System in Natural Waters," Marine Chemistry. Vol 18, pp 121-147. 
Morgan, J. J. 1967. "Chemical Equilibria and Kinetic Properties of Manganese in Natural Waters," Principles and Applications of Water Chemistry. S. U. Faust and J. V. Hunter, eds., Wiley \& Sons, New York, pp 561-624.

Nix, J. 1986. "Spatial and Temporal Distribution of Sulfide and Reduced Metals in the Tailwater of Narrows Dam (Lake Greeson), Arkansas," Technical Report E-86-14, US Army Engineer Waterways Experiment Station, Vicksburg, MS.

Nix, J., Hamlin-Tillman, D. E., Ashby, S. L., and Dortch, M. S. 1991. "Water Quality of Selected Tailwaters," Technical Report W-91-2, US Army Engineer Waterways Experiment Station, Vicksburg, MS.

Noike, T., Kanji, N., and Jun'Ichiro, M. 1983. "Oxidation of Ferrous Iron by Acidophilic Iron-Oxidizing Bacteria from a Stream Receiving Acid Mine Drainage," Water Research, Vo1 17, pp 21-27.

O'Brien, D. J., and Birkner, F. B. 1977. "Kinetics of Oxygenation of Reduced Sulfur Species in Aqueous Solution," Environmental Science and Technology. Vol 11, No. 12, pp 1114-1120.

O'Connor, D. J., and Dobbins, W. E. 1958. "The Mechanism of Reaeration in Natural Stream," Journal of the Sanitary Engineering Division. American Society of Civil Engineers, Vol 82, pp 1-30.

Owens, M., Edwards, R. W., and Gibbs, J. W. 1964. "Some Reaeration Studies in Streams," International Journal of Air and Water Pollution, Vol 8, No. 8/9, pp 469-486.

Paschke, R. A., Hwang, Y. S., and Johnson, D. W. 1977. "Catalytic Oxidation of Sulfide Wastewater from a Cellulose Sponge-Making Operation, " Journal of the Water Pollution Control Federation, pp 2445-2452.

Rathbun, R. E., Shultz, D. J., Stephens, D. W., and Tai, D. Y. 1977. "Experimental Modeling of the Oxygen Absorption Characteristics of Streams and Rivers," Proceedings: Seventeenth Congress of the International Association of Hydraulic Research, 15-19 August, Baden, Federal Republic of Germany.

Rathbun, R. E., Shultz, D. J., Stephens, D. W., and Tai, D. Y. 1978. "Laboratory Studies of Gas Tracers for Reaeration," Journal of the Environmental Engineering Division, American Society of Civil Engineers, Vo1 104, No. EE2, pp 215-229.

Roache, P. J. 1972. Computational Fluid Dynamics, Hermosa Publishing, Albuquerque, NM.

Sarikaya, H. Z. 1990. "Contact Aeration for Iron Removal--A Theoretical Assessment," Water Research, Vol 24, No. 3, pp 329-331.

SAS Institute, Inc. 1988. "SAS/STAT User's Guide," Statistical Analysis System, Inc., Cary, NC.

Stumm, W., and Morgan, J. J. 1981. Aquatic Chemistry, an Introduction Emphasizing Chemical Equilibria in Natural Waters, $2 \mathrm{~d}$ ed., Wiley-Interscience, New York.

Sung, W., and Morgan, J. J. 1980. "Kinetics and Products of Ferrous Iron Oxygenation in Aqueous Systems," Environmental Science and Technology. Vol 14, No. 5, pp 561-568.

TenEch Environmental Consultants, Inc. 1978 (Jul). "Waste Load Allocation Verification Study: Final Report," prepared for Iowa Department of Environmental Quality. 
Thackston, E. L., and Krenke1, P. A. 1969. "Reaeration Prediction in Natural Streams," Journal of the Sanitary Engineering Division. American Socity of Civil Engineers, Vol 95, No. SA1, pp 65-94.

Thibodeaux, L. J. 1979. Chemodynamics: Environmental Movement of Chemicals in Air. Water, and Soil, Wiley \& Sons, New York.

Thomann, R. V., and Mueller, J. A. 1987. Principles of Surface Water Quality Modeling and Control. Harper \& Row, New York.

Tsivoglou, E. C., and Wallace, J. R. 1972. "Characterization of Stream Reaeration Capacity," EPA-R3-72-012, Ecology Research Service, Office of Research and Monitor, US Environmental Protection Agency, Washington, DC.

Wetzel, R. G. 1975. Limnology, W. B. Saunders Company, Philadelphia, PA.

Wilhelms, S. C. 1987. "Results of Reaeration Study on Little Missouri River, Narrows Dam, Arkansas," Memorandum for Record, US Army Engineer Waterways Experiment Station, Vicksburg, MS .

Wilmot, P. D., Cadee, K., Katinic, J. J., and Kavanagh, B. V. 1988 . "Kinetics of Sulfide Oxidation by Dissolved Oxygen," Journal of the Water Pollution Control Federation, Vol 60, No. 7, pp 1264-1270.

Wilson, W. E. 1980. "Surface and Complexation Effects on the Rate of Mn(II) Oxidation in Natural Waters," Geochimica et Cosmochimica Acta, Vol 44, pp 1311-1317. 
APPENDIX A: 1989 NIMROD TAILWATER DATA 
Table A1

Lake Nimrod High Flow (200 cfs)

\begin{tabular}{|c|c|c|c|c|c|}
\hline Station & Time & $\begin{array}{l}\text { Temp. } \\
{ }^{\circ} \mathrm{C} \\
\end{array}$ & $\begin{array}{c}\text { DO } \\
\mathrm{mg} / \ell\end{array}$ & $\mathrm{pH}$ & $\begin{array}{c}\text { Specific } \\
\text { Conductance, } \mu \mathrm{s} / \mathrm{cm} *\end{array}$ \\
\hline
\end{tabular}

August 23,1989

$\begin{array}{lrrrrr}\text { A } & 1634 & 26.0 & 7.0 & 6.5 & 51 \\ \text { B1 } & 1615 & 27.0 & 26.2 & 6.5 & 48 \\ \text { B2 } & 1548 & 25.5 & 6.8 & 6.6 & 48 \\ \text { B3 } & 1519 & 27.0 & 6.7 & 6.5 & 48 \\ \text { C } & 1443 & 28.0 & 6.7 & 6.5 & 46 \\ \text { D } & 1405 & 26.5 & 5.9 & 6.5 & 46\end{array}$

August 24,1989

$\begin{array}{llllll}\text { A } & 1045 & 29.0 & 7.0 & 6.5 & 49 \\ \text { B1 } & 1015 & 29.0 & 6.7 & 6.5 & 50 \\ \text { B2 } & 955 & 27.0 & 6.6 & 6.5 & 48 \\ \text { B3 } & 920 & 27.0 & 6.5 & 6.5 & 48 \\ \text { C } & 815 & 22.5 & 6.1 & 6.5 & 47 \\ \text { D } & 815 & 21.5 & 5.8 & 6.4 & 46\end{array}$

\begin{tabular}{llllllll} 
Station & $\begin{array}{c}\text { Turbidity } \\
\mathrm{NTU}\end{array}$ & $\begin{array}{l}\text { Alkalinity } \\
\mathrm{mg} / \ell\end{array}$ & $\begin{array}{ll}\mathrm{CO}_{2} \\
\mathrm{mg} / \ell\end{array}$ & $\begin{array}{ll}\mathrm{TOC} \\
\mathrm{mg} / \ell\end{array}$ & $\begin{array}{l}\mathrm{TKN} \\
\mathrm{mg} / \ell\end{array}$ & $\begin{array}{l}\mathrm{NH}_{4}-\mathrm{N} \\
\mathrm{mg} / \ell\end{array}$ & $\begin{array}{l}\mathrm{No}_{3} \mathrm{~N} \\
\underline{\mathrm{mg}} / \ell\end{array}$ \\
\hline
\end{tabular}

August 23,1989

$\begin{array}{llllllll}\text { A } & 36 & 16 & 6 & 7 . & 0.6 & 0.28 & 0.03 \\ \text { B1 } & 24 & 19 & 5 & 7 . & 0.5 & 0.22 & 0.04 \\ \text { B2 } & 23 & 14 & 5 & 5 . & 0.6 & 0.20 & 0.07 \\ \text { B3 } & 23 & 14 & 5 & 6 . & 0.6 & 0.18 & 0.07 \\ \text { C } & 22 & 15 & 4 & 6 . & 0.6 & 0.14 & 0.10 \\ \text { D } & 16 & 14 & 6 & 5 . & 0.5 & 0.07 & 0.14\end{array}$

August 24,1989

$\begin{array}{llllllll}\text { A } & 29 & 16 & 5 & 6 . & 0.7 & 0.26 & 0.02 \\ \text { B1 } & 30 & 16 & 5 & 6 . & 0.8 & 0.25 & 0.03 \\ \text { B1 (R) } & 27 & 16 & 6 & 6 . & 0.6 & 0.26 & 0.04 \\ \text { B2 } & 28 & 16 & 5 & 6 . & 0.7 & 0.25 & 0.08 \\ \text { B3 } & 21 & 15 & 6 & 6 . & 0.7 & 0.22 & 0.08 \\ \text { C } & 19 & 15 & 6 & 6 . & 0.5 & 0.19 & 0.11 \\ \text { D } & 18 & 14 & 6 & 5 . & 0.5 & 0.10 & 0.15\end{array}$

(Continued)

* $\mu \mathrm{s}=\mu \mathrm{mhos} / \mathrm{cm}$. 
Table Al (Concluded)

\begin{tabular}{lllllll}
\hline $\mathrm{S}^{-2}$ & $\mathrm{SO}_{4}^{-2}$ & $\mathrm{cl}^{-}$ & Total Fe & Diss. Fe & Total Mn Diss. Mn
\end{tabular}

$\underline{\text { Station } \mu \mathrm{g} / \ell} \underline{\mathrm{mg} / \ell} \underline{\mathrm{mg} / \ell} \underline{\mathrm{mg} / \ell} \quad \frac{\mathrm{mg} / \ell}{\mathrm{mg} / \ell} \mathrm{mg} / \ell$

August 23. 1989

$\begin{array}{lrrrrrrr}\text { A } & 16 & 2.7 & 2.0 & 2.6 & 1.0 & 1.30 & 1.2 \\ \text { B1 } & 17 & 2.9 & 1.9 & 2.1 & 0.8 & 1.00 & 1.0 \\ \text { B2 } & 11 & 2.9 & 2.0 & 1.9 & 0.7 & 0.90 & 0.8 \\ \text { B3 } & 10 & 3.0 & 2.1 & 1.7 & 0.7 & 0.88 & 0.7 \\ \text { C } & 9 & 3.2 & 2.0 & 1.6 & 0.7 & 0.71 & 0.6 \\ \text { D } & 10 & 3.0 & 2.1 & 1.3 & 0.7 & 0.41 & 0.3\end{array}$

August 24,1989

$\begin{array}{llllllll}\text { A } & 17 & 2.7 & 1.9 & 2.4 & 0.9 & 1.20 & 1.1 \\ \text { B1 } & 12 & 3.2 & 2.0 & 2.2 & 0.9 & 1.20 & 1.1 \\ \text { B1 (R) } & 11 & 2.7 & 2.0 & 2.2 & 0.9 & 1.20 & 1.1 \\ \text { B2 } & 11 & 2.8 & 2.0 & 2.1 & 0.8 & 1.10 & 1.0 \\ \text { B3 } & 10 & 1.9 & 3.0 & 1.9 & 0.8 & 0.95 & 0.8 \\ \text { C } & 11 & 2.9 & 2.0 & 1.8 & 0.8 & 0.82 & 0.7 \\ \text { D } & 10 & 2.8 & 2.0 & 1.4 & 0.8 & 0.42 & 0.3\end{array}$

Note: $B 1(R)$ is a repeated sampling of station $B 1$. 
Table A2

Lake Nimrod Profiles

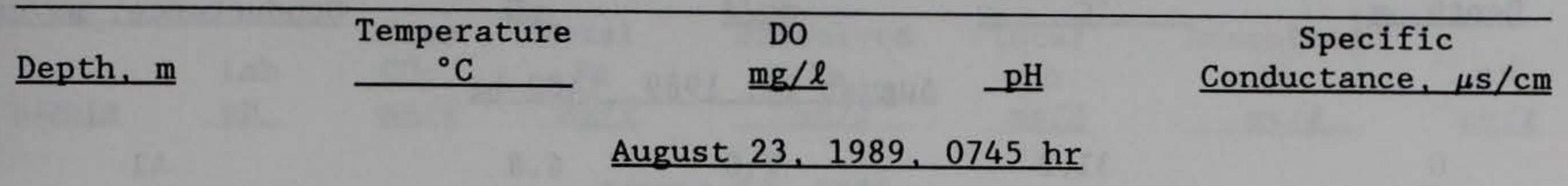

28.3

28.3

28.1

27.9

27.4

26.6

26.2

26.0

25.9

25.7

25.0

5.4

6.7

40

5.3

6.6

6.6

4.1

3. 3

2.2

0.7

0.1

0.0

0.0

0.0

0.0

6.6

6.4

6.3

6.2

6.2

6.2

6.2

6.2

40

40

40

41

42

44

47

49

55

64

August $23,1989,1845 \mathrm{hr}$

28.0

28.2

27.6

26.5

26.3

26.2

26.1

26.0

25.7

25.5

24.8

$\begin{array}{ll}6.4 & 6.8 \\ 4.4 & 6.7 \\ 2.1 & 6.5 \\ 0.2 & 6.4 \\ 0.1 & 6.3 \\ 0.0 & 6.3 \\ 0.0 & 6.2 \\ 0.0 & 6.2 \\ 0.0 & 6.2 \\ 0.0 & 6.2 \\ 0.0 & 6.2\end{array}$

41

41

41

44

46

46

47

52

61

61

71

August $24,1989,0650 \mathrm{hr}$

27.2

27.2

27.2

27.2

26.8

26.2

26.0

25.9

25.8

25.6

24.9
3. 0

3. 1

3.0

2. 8

0.6

0.0

0.0

0.0

0.0

0.0

0.0

6.4

6.4

6.4

6. 3

6.2

6.2

6.2

6.2

6.1

6.1

6.2

(Continued) 
Table A2 (Concluded)

\begin{tabular}{|c|c|c|c|c|}
\hline Depth, m & $\begin{array}{c}\text { Temperature } \\
{ }^{\circ} \mathrm{C} \\
\end{array}$ & $\begin{array}{c}\text { DO } \\
\mathrm{mg} / \ell\end{array}$ & $\mathrm{pH}$ & $\begin{array}{c}\text { Specific } \\
\text { Conductance, } \mu \mathrm{s} / \mathrm{cm}\end{array}$ \\
\hline \multicolumn{5}{|c|}{ August $24,1989,1400 \mathrm{hr}$} \\
\hline 0 & 31.2 & 7.0 & 6.8 & 41 \\
\hline 1 & 30.9 & 6.8 & 6.8 & 41 \\
\hline 2 & 30.1 & 6.4 & 6.7 & 41 \\
\hline 3 & 28.2 & 2.9 & 6.5 & 42 \\
\hline 4 & 27.8 & 2.9 & 6.1 & 42 \\
\hline 5 & 27.5 & 0.2 & 6.1 & 41 \\
\hline 6 & 26.6 & 0.0 & 6.1 & 47 \\
\hline 7 & 26.4 & 0.0 & 6.1 & 50 \\
\hline 8 & 26.3 & 0.0 & 6.1 & 51 \\
\hline 9 & 26.2 & 0.0 & 6.1 & 53 \\
\hline 10 & 25.7 & 0.0 & 6.1 & 61 \\
\hline
\end{tabular}


Table A3

Lake Nimrod In-pool Water Quality

\begin{tabular}{|c|c|c|c|c|c|c|c|}
\hline Sample & $\begin{array}{l}\mathrm{Lab} \\
\mathrm{pH} \\
\end{array}$ & $\begin{array}{l}\text { Free } \\
\mathrm{CO}_{2} \\
\mathrm{mg} / \ell \\
\end{array}$ & $\begin{array}{c}\text { Total } \\
\mathrm{Fe} \\
\mathrm{mg} / \ell \\
\end{array}$ & $\begin{array}{c}\text { Dissolved } \\
\mathrm{Fe} \\
\mathrm{mg} / \ell \\
\end{array}$ & $\begin{array}{c}\text { Total } \\
\mathrm{Mn} \\
\mathrm{mg} / \ell \\
\end{array}$ & $\begin{array}{c}\text { Dissolved } \\
\mathrm{Mn} \\
\mathrm{mg} / \ell \\
\end{array}$ & $\begin{array}{c}\mathrm{s}^{-2} \\
\mu \mathrm{g} / \ell\end{array}$ \\
\hline \multicolumn{8}{|c|}{ August 23, 1989} \\
\hline $\mathrm{N}-1-0$ & 6.64 & 4 & 0.82 & 0.41 & 0.09 & 0.00 & 6 \\
\hline $\mathrm{N}-1-1$ & 6.60 & 4 & 0.79 & 0.35 & 0.09 & 0.01 & 7 \\
\hline $\mathrm{N}-1-2$ & 6.60 & 6 & 0.84 & 0.45 & 0.10 & 0.01 & 7 \\
\hline $\mathrm{N}-1-3$ & 6.54 & 7 & 0.93 & 0.47 & 0.12 & 0.01 & 6 \\
\hline $\mathrm{N}-1-4$ & 6.47 & 8 & 0.95 & 0.48 & 0.14 & 0.02 & 8 \\
\hline$N-1-5$ & 6.33 & 10 & 1.4 & 0.57 & 0.45 & 0.30 & 9 \\
\hline $\mathrm{N}-1-5 \mathrm{R}$ & 6.33 & 9 & 1.4 & 0.55 & 0.38 & 0.24 & 10 \\
\hline $\mathrm{N}-1-6$ & 6.36 & 10 & 1.5 & 0.57 & 0.47 & 0.30 & 10 \\
\hline $\mathrm{N}-1-7$ & 6.41 & 11 & 2.0 & 0.48 & 0.90 & 0.79 & 10 \\
\hline$N-1-8$ & 6.39 & 10 & 2.1 & 0.43 & 1.1 & 1.0 & 14 \\
\hline$N-1-9$ & 6.40 & 12 & 2.6 & 0.90 & 1.5 & 1.4 & 14 \\
\hline$N-1-10$ & 6.39 & 13 & 3.2 & 1.4 & 1.9 & 1.8 & 30 \\
\hline
\end{tabular}

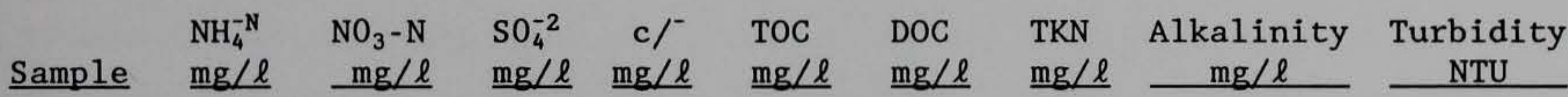
August 23,1989

\begin{tabular}{|c|c|c|c|c|c|c|c|c|c|}
\hline $\mathrm{N}-1-0$ & 0.02 & 0.03 & 3.90 & 2.2 & 4.4 & 3.1 & 0.4 & 11 & \\
\hline$N-1-1$ & 0.03 & 0.02 & 2.89 & 2.0 & 4.2 & 3.0 & 0.8 & 11 & 10.0 \\
\hline$N-1-2$ & 0.05 & 0.03 & 2.99 & 2.1 & 4.2 & 3.2 & 0.6 & 11 & 11.0 \\
\hline$N-1-3$ & 0.08 & 0.03 & 3.20 & 2.2 & 4.1 & 3.3 & 0.6 & 11 & 14.0 \\
\hline$N-1-4$ & 0.08 & 0.03 & 3.36 & 2.1 & 5.3 & 3.3 & 0.5 & 11 & 11.0 \\
\hline$N-1-5$ & 0.14 & 0.03 & 3.98 & 2.0 & 4.4 & 3.6 & 0.8 & 12 & 20.0 \\
\hline$N-1-5 R$ & 0.13 & 0.02 & 3.64 & 1.9 & 4.5 & 3.4 & 0.8 & 12 & 21.0 \\
\hline$N-1-6$ & 0.13 & 0.02 & 3.10 & 2.0 & 4.1 & 3.2 & 0.6 & 12 & 21.0 \\
\hline$N-1-7$ & 0.20 & 0.02 & 2.94 & 2.0 & 4.2 & 3.4 & 0.7 & 14 & 31.0 \\
\hline$N-1-8$ & 0.23 & 0.05 & 3.54 & 2.4 & 3.9 & 3.8 & 0.7 & 14 & 30.0 \\
\hline$N-1-9$ & 0.32 & 0.04 & 3.27 & 2.4 & 4.0 & 3.4 & 0.7 & 17 & 35.0 \\
\hline $\mathrm{N}-1-10$ & 0.42 & 0.06 & 2.75 & 2.5 & 4.7 & 3.3 & 0.08 & 18 & 39.0 \\
\hline
\end{tabular}


APPENDIX B: MODEL OPERATION 


\section{Introduction}

1. The Tailwater Quality Model (TWQM) is a user-friendly, interactive, menu-driven, PC-based model of water quality in reservoir tailwaters. TWQM computes the one-dimensional (1D), longitudinal, steady-state distribution of water quality along the stream axis, beginning at the reservoir release and progressing downstream for any number of miles as specified by the user. The model was developed to evaluate downstream water quality characteristics resulting from reservoir releases. Examples of the types of issues affecting tailwater quality that might be addressed include:

a. Changes in the reservoir outlet elevation and/or release flow.

b. Changes in release reaeration characteristics, such as adding hydropower (i.e., add-on hydropower).

c. Changes in release water quality due to degradation of in-pool water quality.

d. Changes in the downstream channel, such as reregulation.

TWQM focuses on the problematic water quality variables, such as low dissolved oxygen and reduced substances (e.g., dissolved iron, dissolved manganese, ammonium, and sulfide), but includes biochemical oxygen demand, major nutrients, and algae. The model can also be used to evaluate the downstream distance required for recovery of water quality to some standard. TWQM is designed for ease of application with limited input requirements (due mainly to the steady-state assumption). A first-time user should be able to apply the model within a few days. An experienced user should be able to apply the model within a day, given that all the data are in hand.

2. TWQM is composed of a number of programs (i.e., pre- and postprocessor programs and a numerical model) that are menu driven. TAILWTR.FOR is the numerical one-dimensional tailwater model based on the US Environmental Protection Agency riverine water quality mode1 QUAL2E. TAILWTR.FOR predicts estimates of constituent concentrations in a river reach based on the input parameters given. The main batch file that executes all the programs that make up TWQM is TWQB.BAT. Descriptions of each program and its output are given in Table B1. The order in which TWQB.BAT calls these files is shown in Figure B1. The first several programs executed by TWQB are pre-processor programs that assist the user in using TWQM (giving general information and instructions) and also assist the user in creating an input data set for 
File

TWQB . BAT

TEXPLAIN . FOR

TMENU. FOR

TWQI . FOR

TFIX. FOR

TAILWTR. FOR

TREFORM. FOR

TPREDICT.DAT

TPFILE. FOR and TPFILEPL.FOR

TWGRAPH. BAT and TWPLOT.BAT

TPGRAPH. BAT and TPPLOT.BAT

\section{Description}

Batch program that runs all files contained in the Tailwater Quality Model.

Prints screens containing general information and instructions for TWQM.

Allows the user to select which water quality constituents are to be modeled and input headwater boundary conditions for those constituents selected.

Creates the input data file required by TAILWTR. FOR. Also creates the file containing observed data, OBSERVED.DAT, which is used by K4GRAPH. BAT to graph observed data.

Allows the user to alter an existing input data file.

Determines the tailwater quality of dam discharges. Creates a user-named output file, and the files PREDICT.DAT and PREDICT.HYD.

Reads PREDICT.DAT and PREDICT.HYD and combines them into one file, TPREDICT.DAT.

Data file for all graphing (graph viewed on monitor) and plotting (hard copy of graph) files. Contains output for all elements for selected constituents from the last run of TAILWTR. FOR.

Creates the files used by TPGRAPH.BAT (*.TPL) and TPPLOT.BAT (*.PLT) for graphing and plotting TAILWTR.FOR output.

Batch files which call the graphing and plotting programs written for GRAPHER software (Golden Software, Inc. 1988). Uses files with AXS, GRF, and PLT extensions.

Batch files which call graphing and plotting software written for TPLOT software (Benton 1987). Uses files with TPL and PLT extensions. 
TWQB STRUCTURE

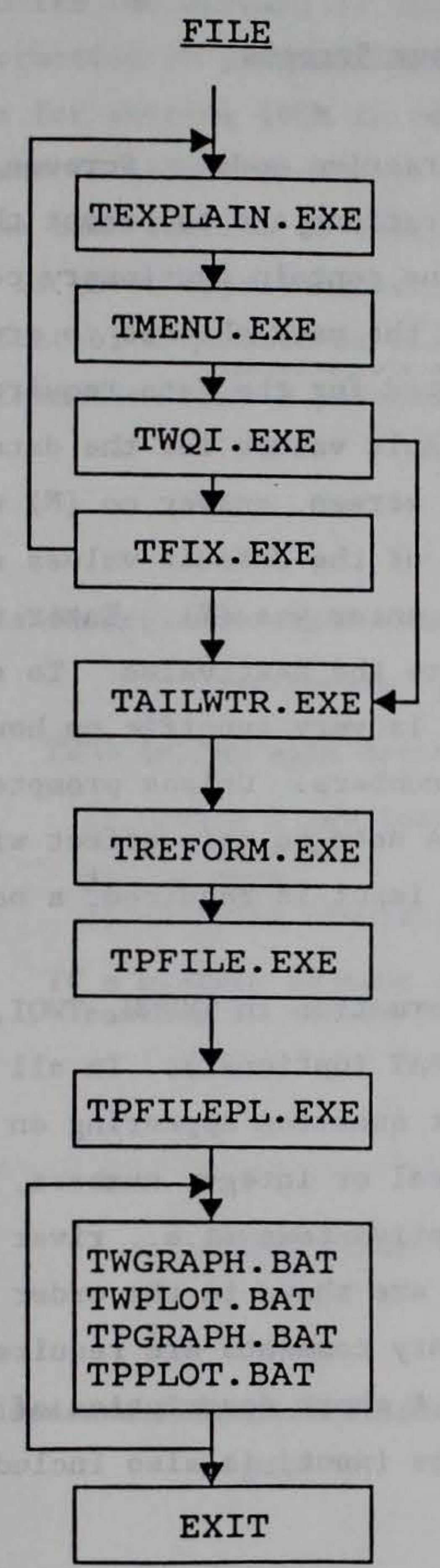

FILES CREATED

TITLE.DAT

TAILWTR DATA FILE*

OBSERVED. DAT

TAILWTR OUTPUT FILE*

PREDICT. DAT

PREDICT. HYD

TPREDICT.DAT

*.TPL

*. PLT

* These files can have any name up to eight characters in length and an extension up to three characters long.

Figure B1. Order in which TWQB.BAT calls up files 
TAILWTR.FOR. Output from TAILWTR.FOR is plotted using commercial software such as GRAPHER (Golden Software, Inc. 1988)* or TPLOT (Benton 1987).

\section{Tailwater Model Input Screens}

3. The TWQM is a user-friendly, interactive model. Screens have been developed to assist the user with model operations and to prompt the user for appropriate information. The initial screens contain cautionary comments about the model and input requirements. If the user chooses to create a new input data set for TAILWTR.FOR, he is prompted for the data required. In many instances these screens already contain default values for the data. To select ALL of the default values shown on a screen, answer no (N) when asked if changes need to be made. To select some of the default values shown on the screen and enter new values for the others, enter yes $(Y)$. Enter the new values where desired and press ENTER to go to the next value. To select the default value shown, press ENTER. The TWQM is very specific on how the data are input with respect to integer and real numbers. Unless prompted otherwise, all numerical input should be real. A note to this effect will appear on all screens. In instances where integer input is required, a note will appear indicating so.

4. The user is required to input information in TMENU, TWQI, TFIX, TAILWTR, and the graphics program GRAFMENU.BAT (optional). In all cases the required input will be an answer to a direct question appearing on the screen. Types of entries required by the user are real or integer numbers, yes or no answers, data file names, or a short descriptive text (i.e., river name).

5. In the following section, screens are shown in the order that they appear to the user when explanatory/cautionary comments are required for clarification, or when user input is required. A short description of each screen, along with information concerning the input, is also included.

* See References at the conclusion of the main text. 


\section{Screens in TEXPLAIN. FOR}

6. This program does not require any user input, but the information contained on its two screens is VERY important. The first screen contains general information on program TWQB.BAT (Figure B2). It also contains instructions for exiting TWQM in case of an error by pressing the control (CTRL) key and 'C' simultaneously. It must be noted that this should be done only when the user desires to start all over again. TWQM is structured so that a user is given opportunities to change answers if incorrect values are entered. 'Control $C$ ' should be used only as a last resort since the user will lose any information that a particular program in TWQM has not written to a file.

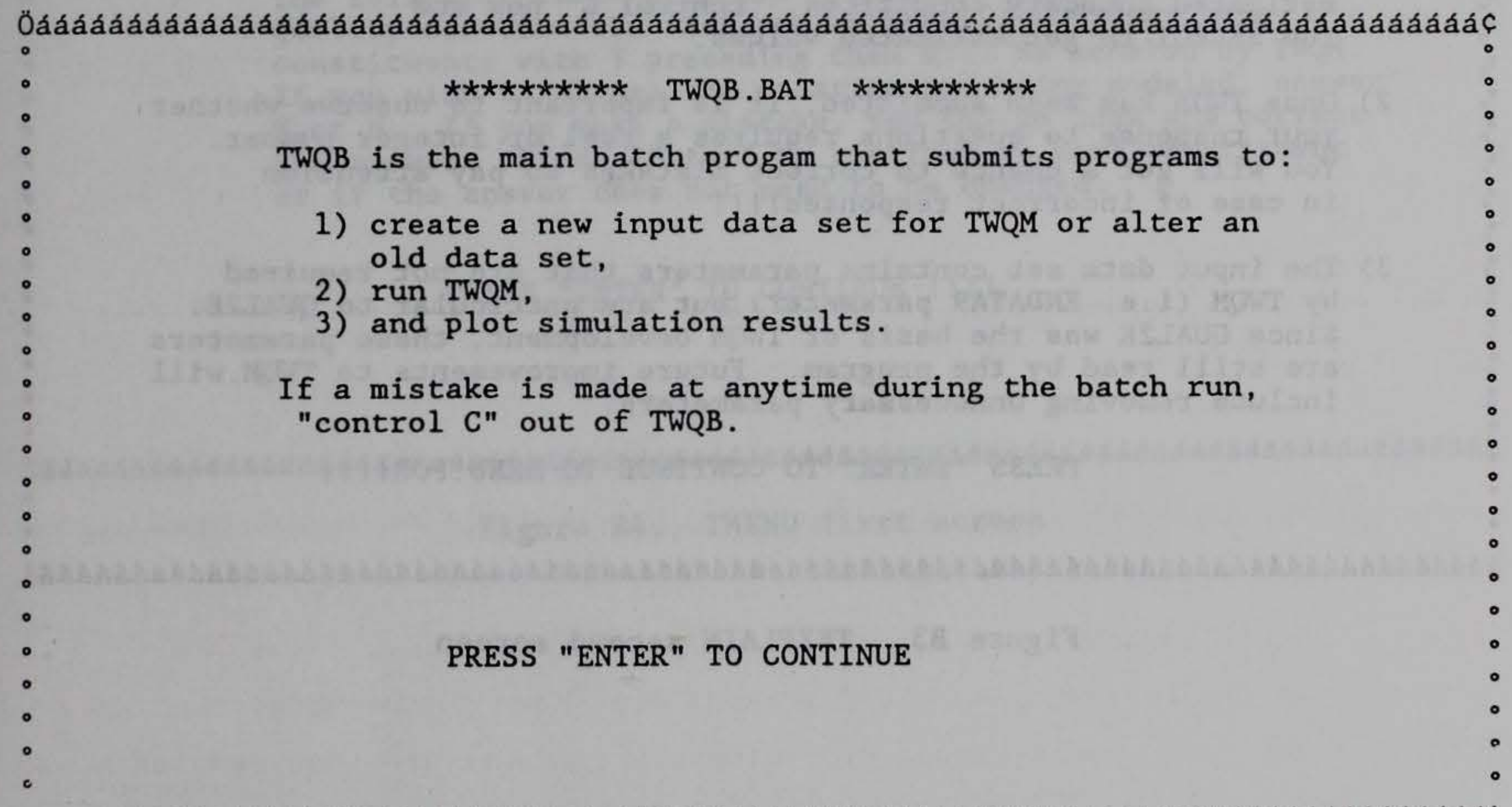

âááááááááááááááááááááááááááááááááááááááááááááááááááááááááááááááááááááái Figure B2. TEXPLAIN first screen 
7. The next screen in TEXPLAIN contains more cautionary comments (Figure B3). The most important one is that release values for headwater boundary conditions (see Headwater Data Screen) are required before running TWQM. If these values are not available, they can be estimated from in-pool profiles using the selective withdrawal model, SELECT (Davis et al. 1987). If SELECT must be run, TWQM should be exited at this time by pressing the CTRL key and 'C' simultaneously.

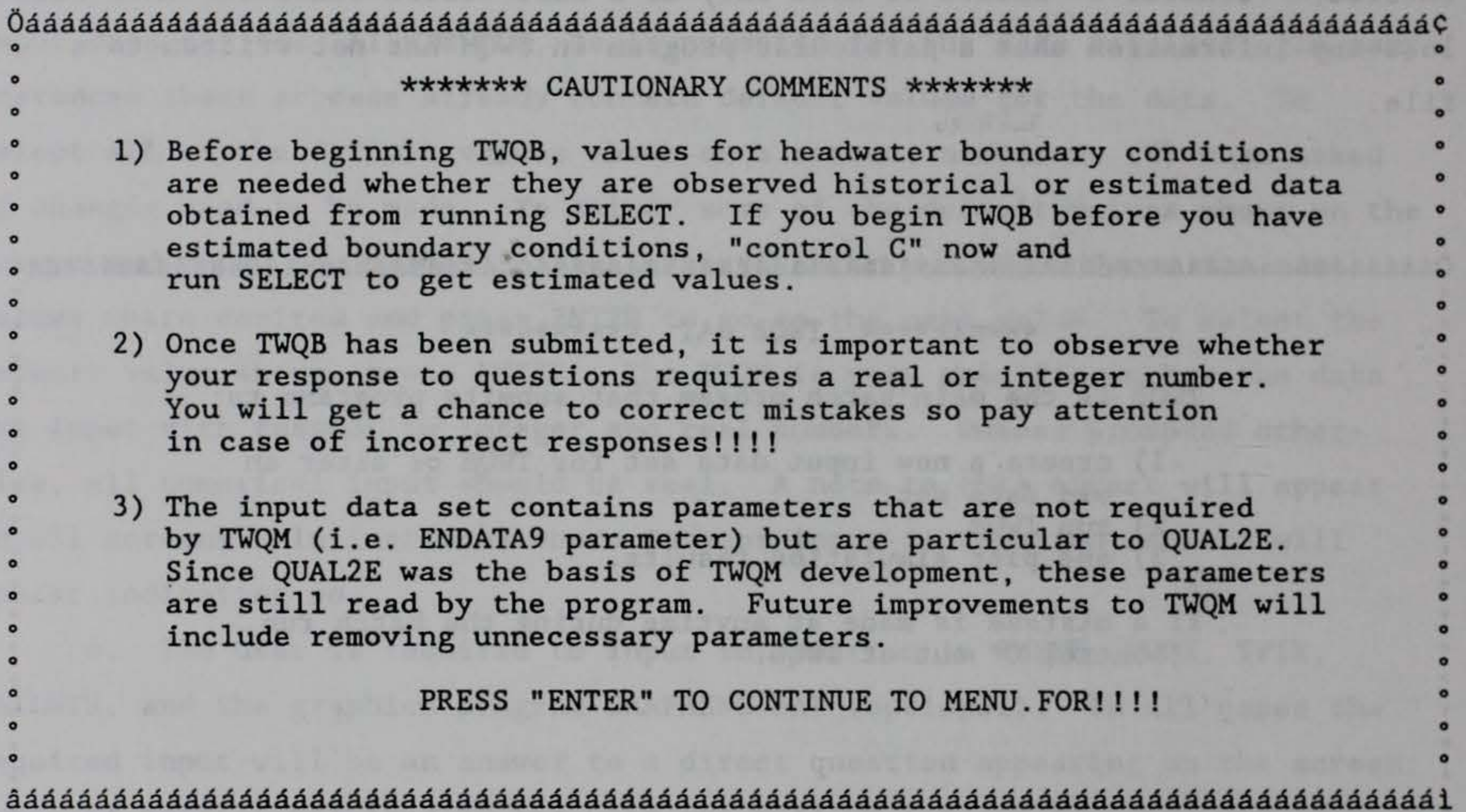

Figure B3. TEXPLAIN second screen 


\section{Screens in TMENU. FOR}

8. The first screen in TMENU contains general information concerning the program (Figure B4). Note that if incorrect responses are entered on the following table (Figure B5), there will be an opportunity to correct them before proceeding to the next screen.

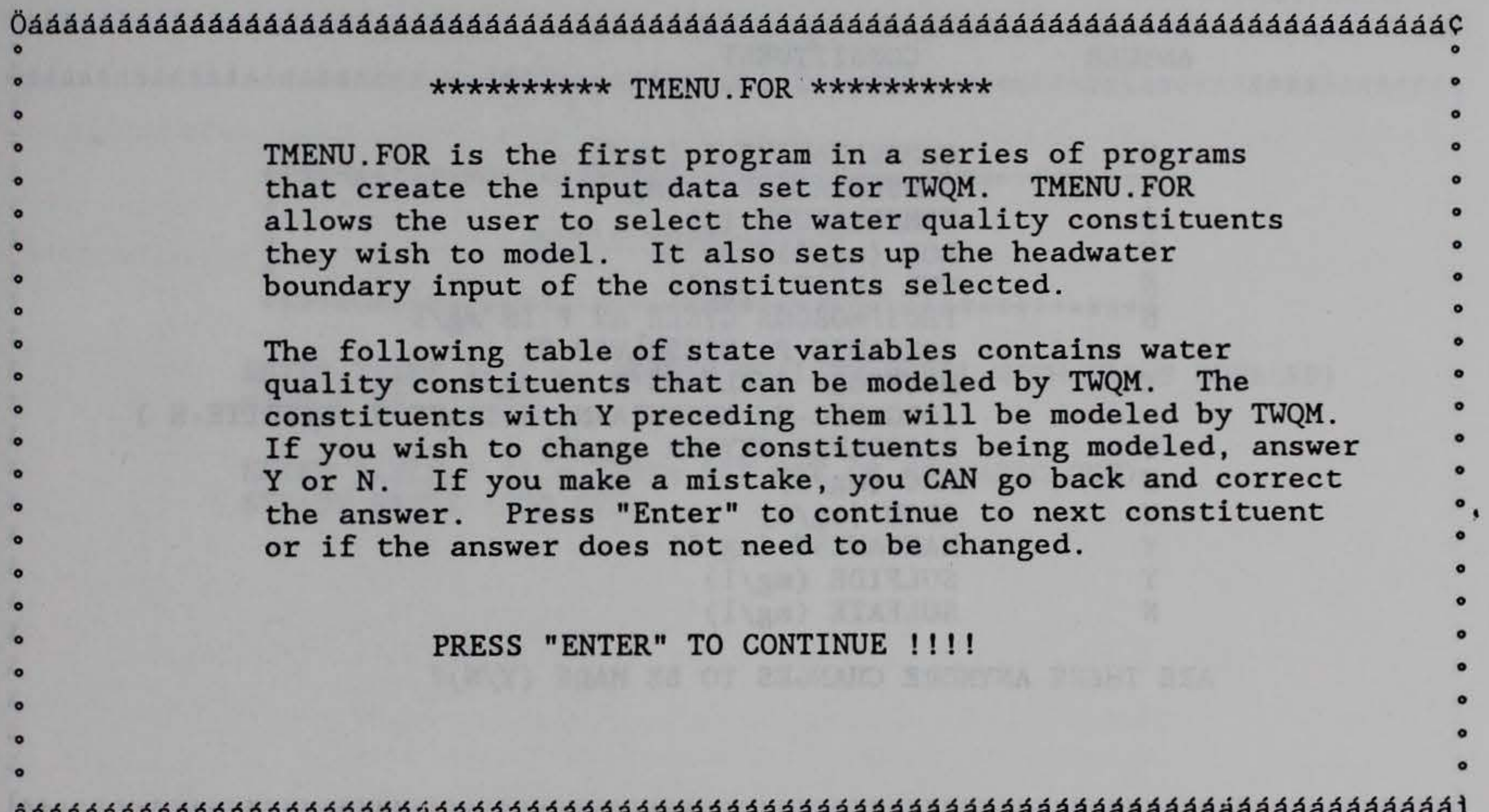

âáááááááááááááááááááááááááááááááááááááááááááááááááááááááááááááááááááái

Figure B4. TMENU first screen 
9. The next screen in TMENU lists all constituents that TAILWTR can model (Figure B5). The constituents that will be modeled are selected from this list by entering ' $\mathrm{Y}$ ' at the flashing cursor. Choices made here are very important since they determine not only which processes will be simulated but also what input data are required.

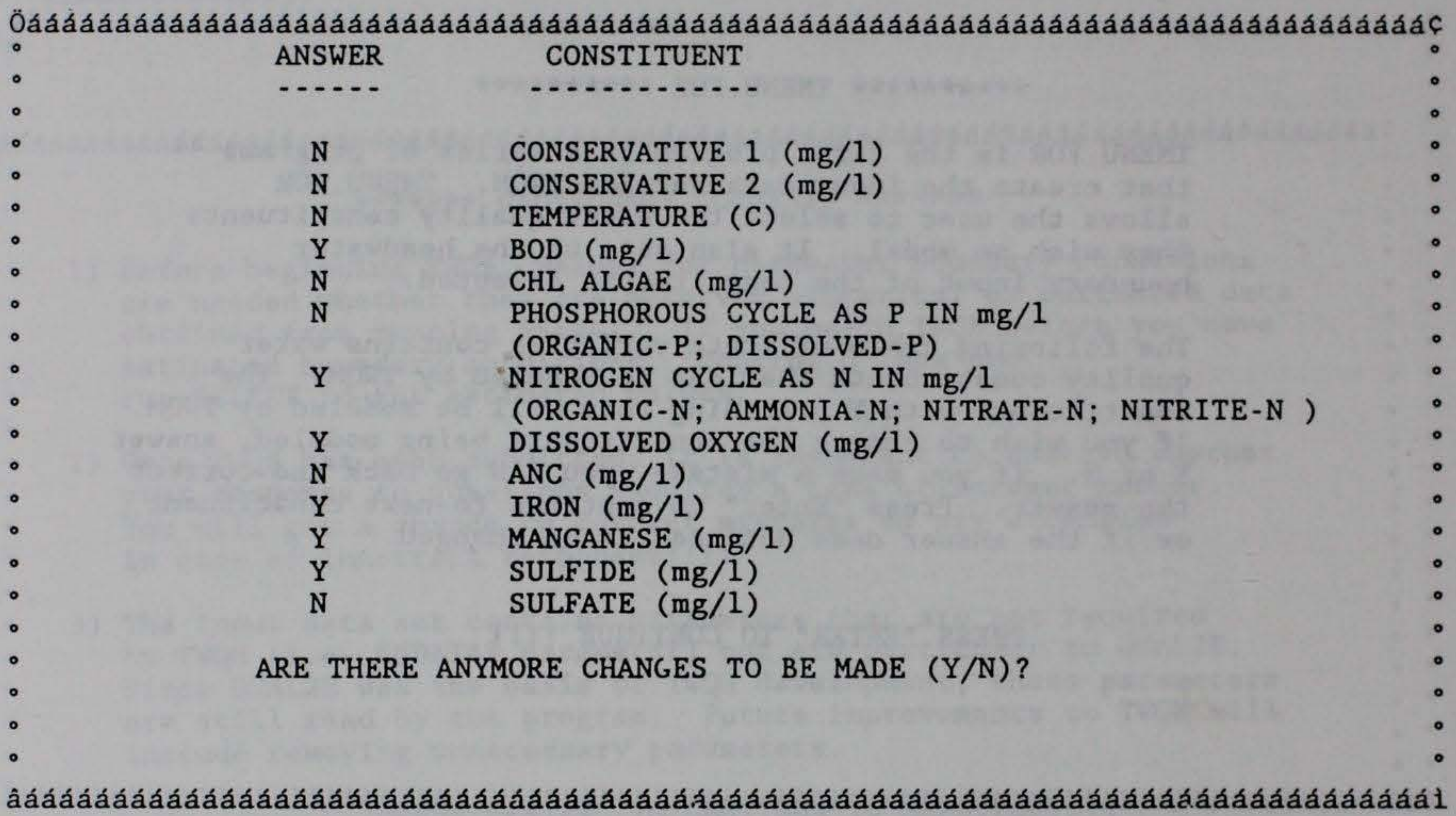

Figure B5. TMENU second screen 
10. Using the title information screen, the user enters two titles for this simulation (Figure B6). For example, if a user decides to decrease the release flow from a project by half, one of the titles could be "Nimrod Reservoir - Flow Halved." The other title could be used to identify project name and date of simulation. These titles can be up to 80 characters long and are the first two lines in the input data file for TAILWTR.

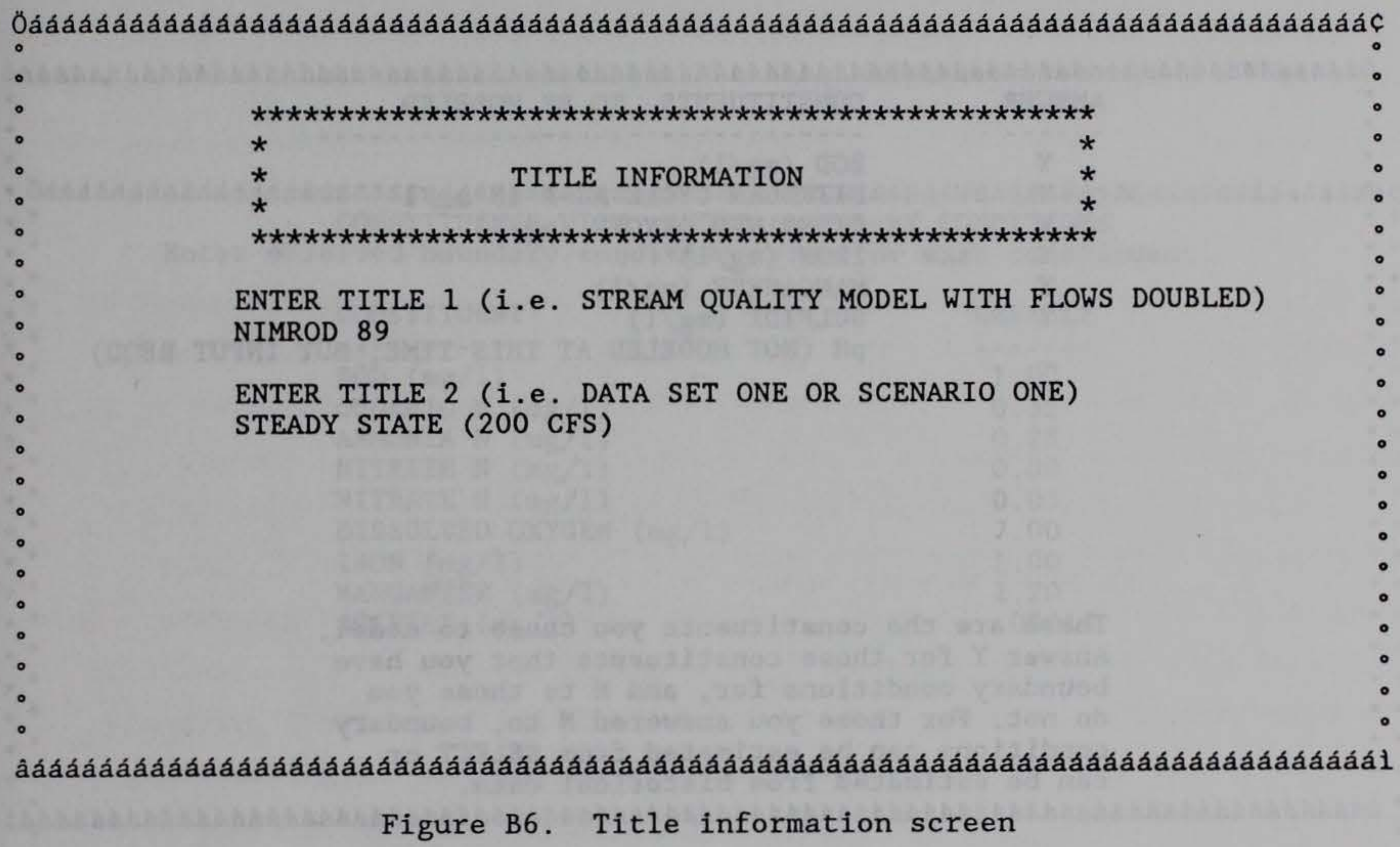


11. The next screen in TMENU (Figure B7) consists of a list of the constituents that were selected earlier (Figure B5) to be modeled. Answer yes (Y) to those constituents for which the headwater boundary conditions are known and no (N) to those for which boundary conditions are not known. On subsequent screens the observed boundary condition values and estimated (using SELECT) boundary conditions are entered for all constituents being modeled (Figure B8).

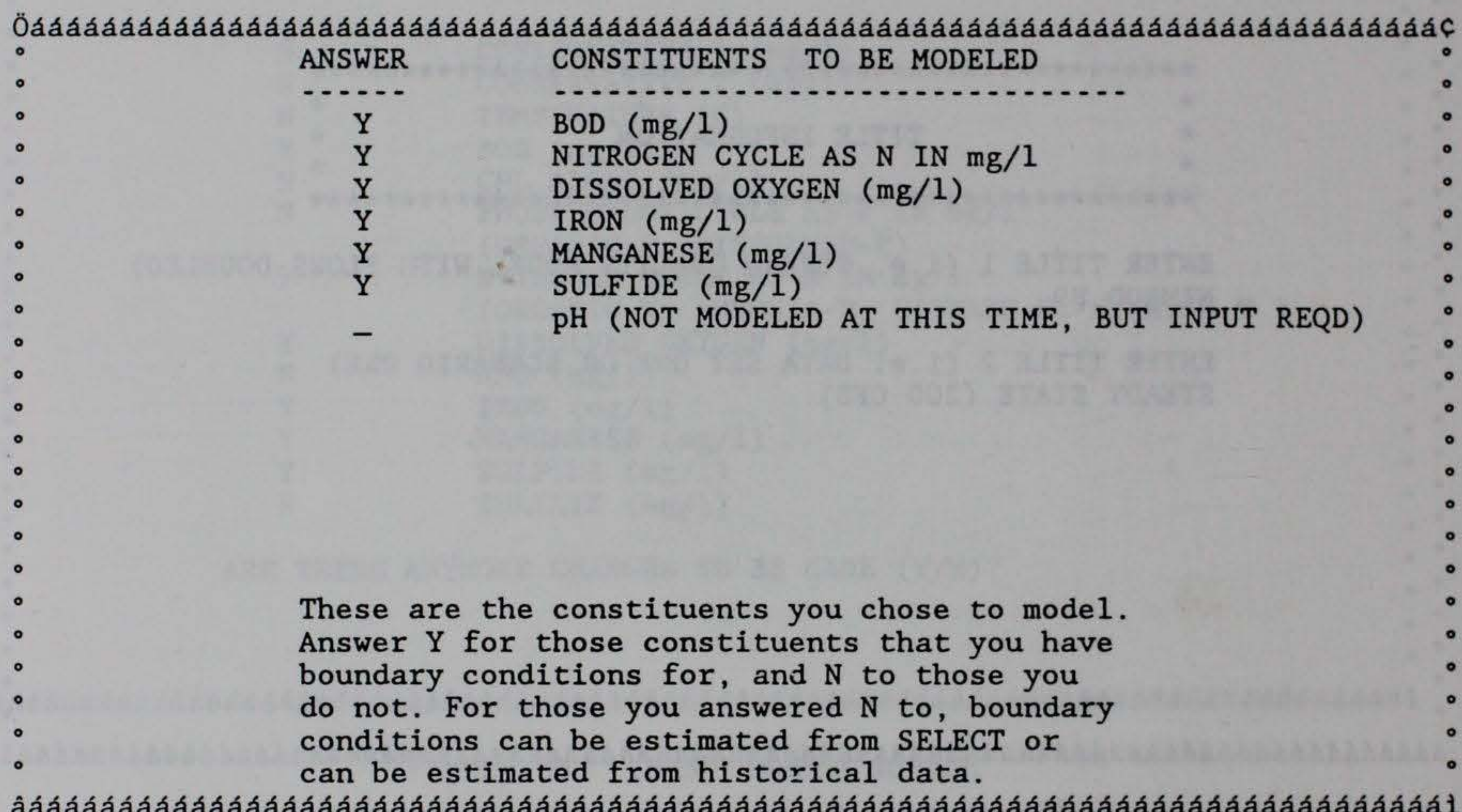

âáááááááááááááááááááááááááááááááááááááááááááááááááááááááááááááááááái

Figure B7. Constituents to be modeled 
Oaáááááááááááááááááááááááááááááááááááááááááááááááááááááááááááááááááááááááááááác - CONSTITUENTS WITH -KNOWN- BOUNDARY CONDITIONS

\section{CONSTITUENT}

BOD (mg/l)

ORGANIC $\mathrm{N}(\mathrm{mg} / \mathrm{l})$

AMMONIA N (mg/1)

NITRITE $\mathrm{N}(\mathrm{mg} / 1)$

NITRATE N (mg/1)

DISSOLVED OXYGEN (mg/1)

IRON (mg/1)

MANGANESE (mg/1)

SULFIDE (mg/l)
DEFAULT

1.00

0.32

0.28

0.00

0.03

7.00

1.00

1.20

.00016

Figure B8. Known boundary conditions 


\section{Screens in TWQI.FOR}

12. TWQI is the main interactive program in TWQM and serves as a preprocessor that generates the input data file for TAILWTR. Since TAILWTR was developed using QUAL2E, the data file generated by TWQI is very similar to a QUAL2E input data file.

13. TWQI prompts the user for most input required to generate a data file for TAILWTR. Some data such as evaporation coefficients and certain constants are included in TWQI but are not user definable and will not appear on any menus. There is usually a default value for the data that the user must enter. The notable exceptions are input dealing with flow and location (river mile). A value MUST be entered for these before any simulation can be performed even though a default value of 0.0 appears on the screen.

14. TWQI is very specific concerning input format. The importance of reading and following the directions at the bottom of each screen cannot be overemphasized. Most values that are input into TWQI must be real numbers. However, there are certain instances when integer values are required by TWQI. Unless indicated otherwise, all numeric input is to be in real numbers.

15. The first screen of TWQI is the title screen which contains a description of TWQI (Figure B9). Upon pressing RETURN (or ENTER), TWQI prompts the user for the name of the input data file TWQI will generate. This file will be a new file; the name of an existing file must not be used. If the file name of an existing file is used, TWQI will stop. This precaution prevents a user from erroneously writing over an existing data file. The file name must not exceed eight characters and may have an extension of up to three characters. 


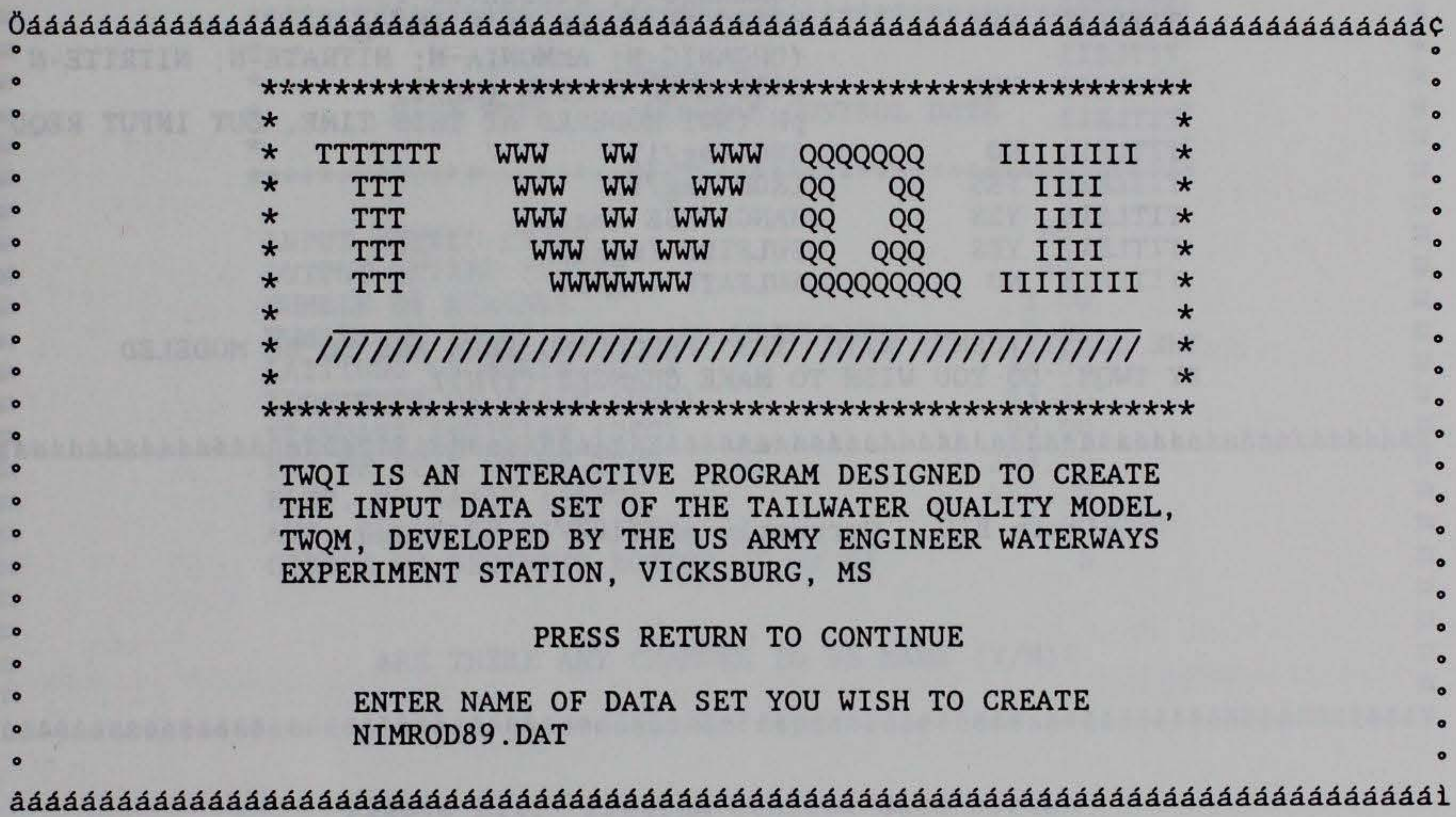

Figure B9. Title screen 
16. The next screen echoes the data input earlier in TMENU (Figure B5) dealing with what constituents will be modeled (Figure B10). This information should not be changed unless it was entered incorrectly in TMENU.

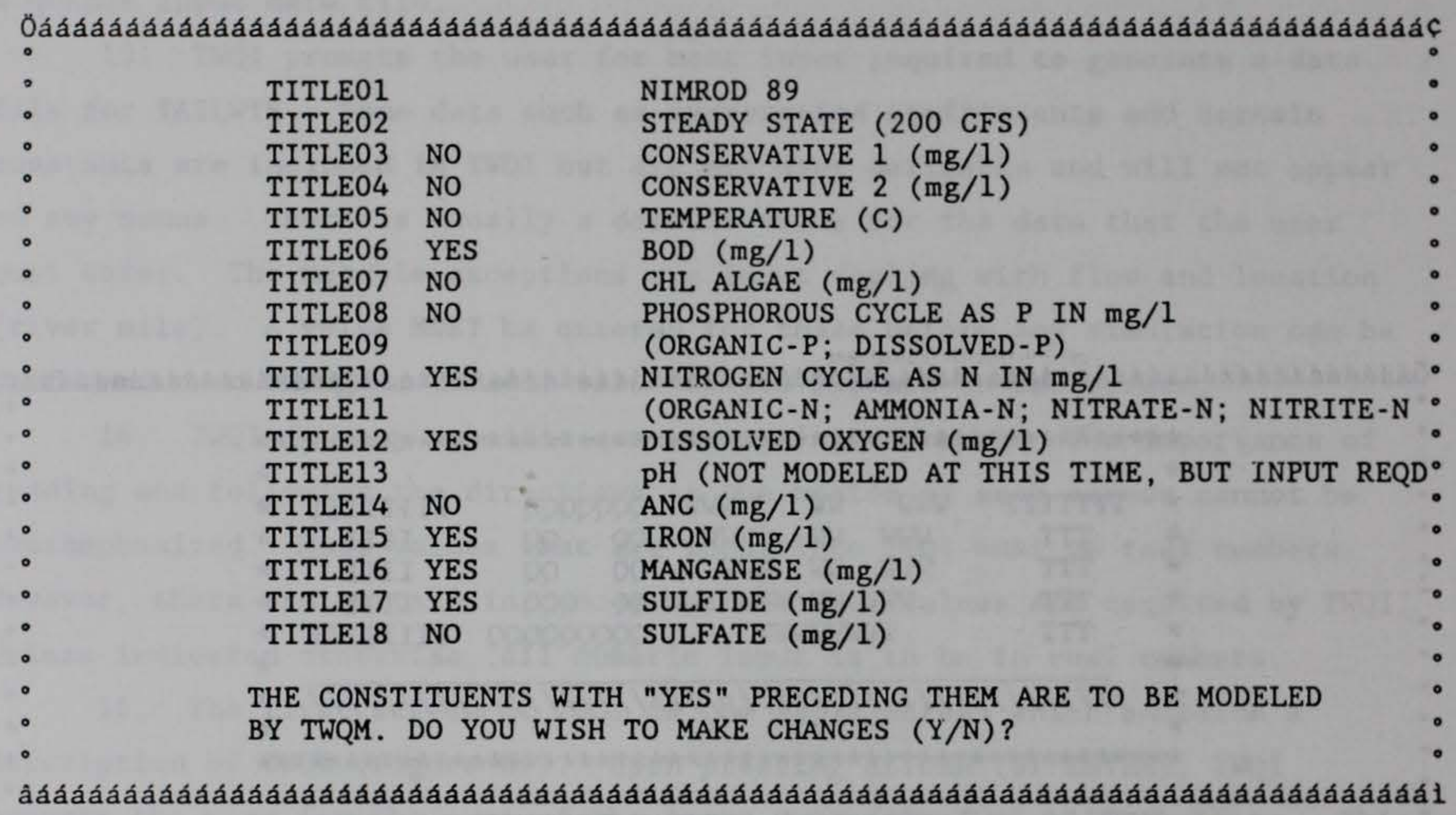

Figure B10. Currently modeled constituents 
17. Screen 2 contains the program control data (Figure B11). The screen is self-explanatory. If no (N) is entered for the input metric question, the input must be in the non-metric units specified. If no (N) is entered for the output metric option, the output will be in non-metric units. One item of interest is the value for the average slope of the riverbed. These data are required by the algorithm that determines the computational element length. A default value corresponding to a slope of $1 \mathrm{ft}$ to $10,000 \mathrm{ft}$ is shown. This value can be changed, but a slope of $0 \mathrm{ft} / \mathrm{ft}$ is not allowed.

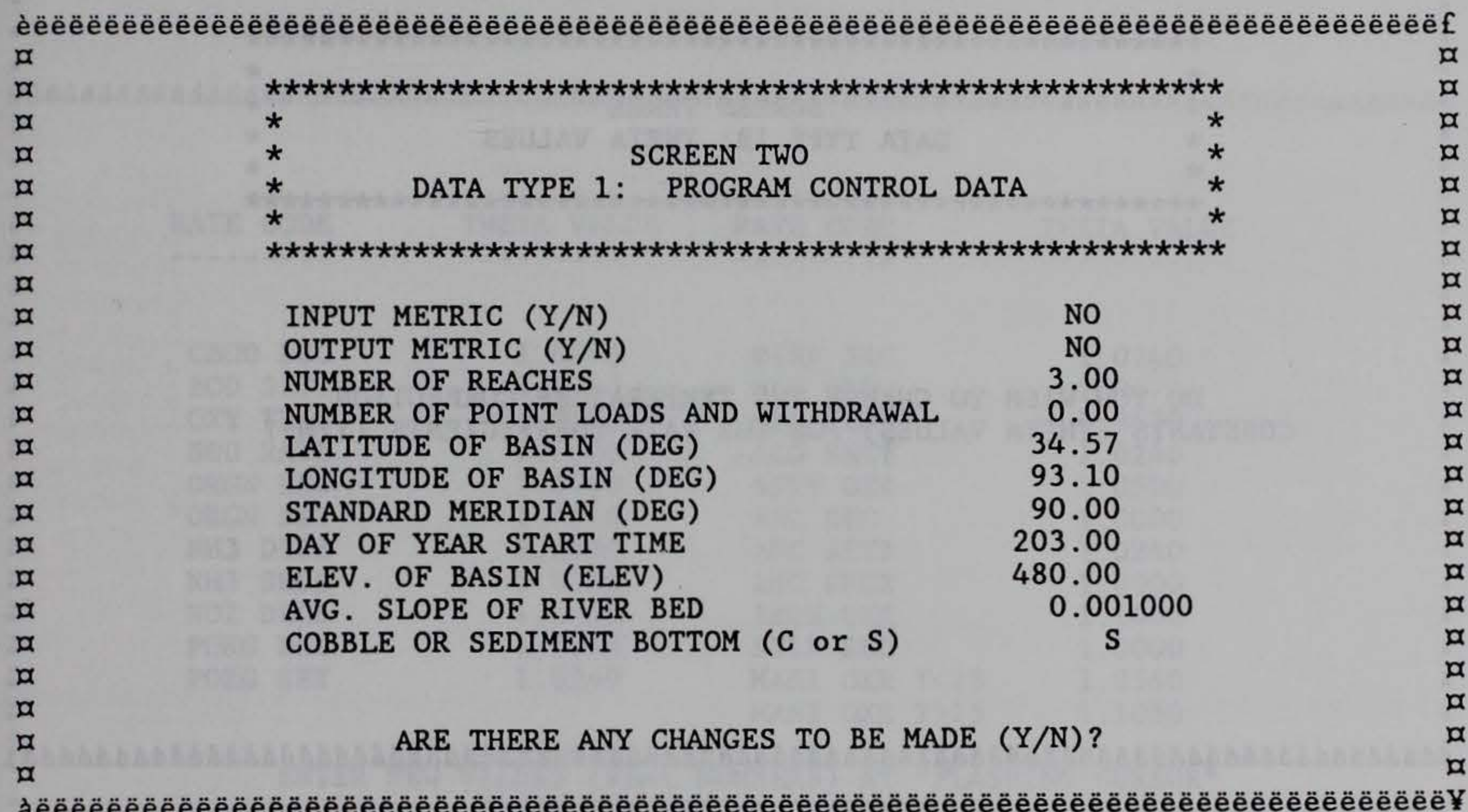

Figure B11. Program control data screen 
18. The next screen (Figure B12) asks the user if changes to the theta values are required. Theta values are used to correct for the effects of temperature upon reaction rates. If no (N) is entered, TWQI proceeds to screen four, and TAILWTR uses default theta values (Brown and Barnwell 1987). If the answer is yes ( $Y$ ), a list of the default theta values appears, and changes can be made to any value (Figure B13). Once all changes are made, the theta values are printed to the screen one last time.

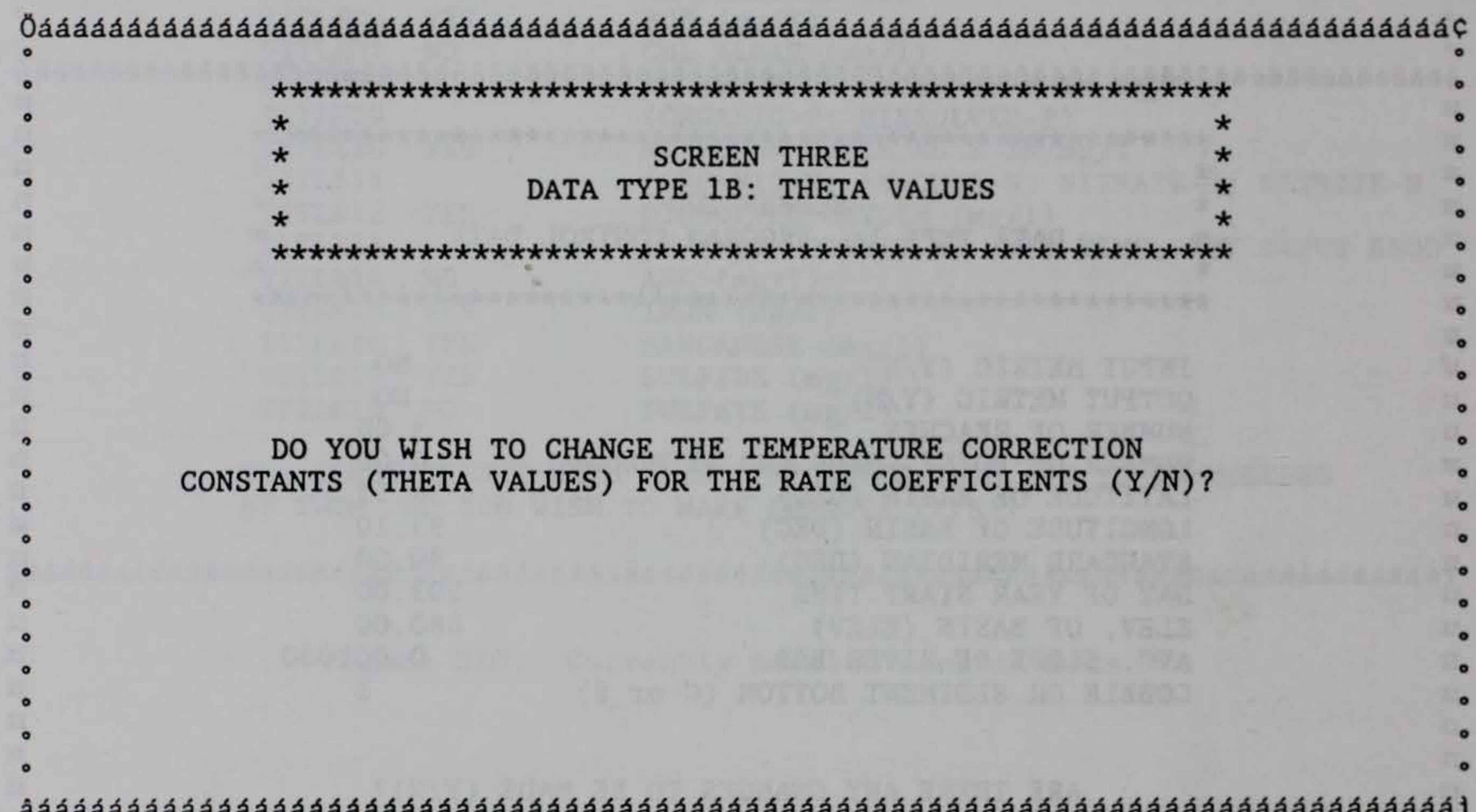

âáááááááááááááááááááááááááááááááááááááááááááááááááááááááááááááááááááál Figure B12. First theta screen 


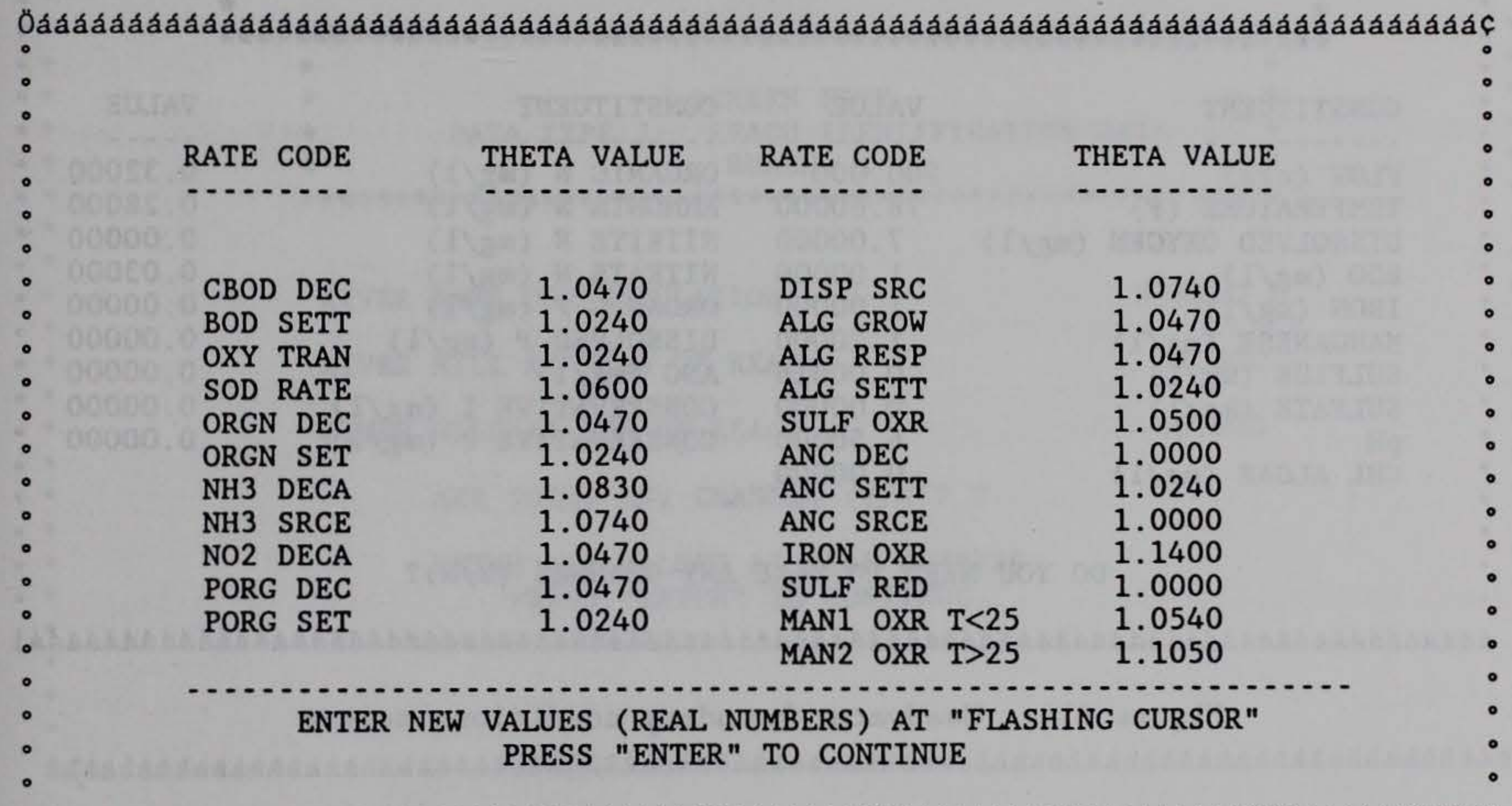

âááááááááááááááááááááááááááááááááááááááááááááááááááááááááááááááááááál

Figure B13. Theta changes screen 
19. Screen 4 (Figure B14) contains the headwater boundary conditions entered in TMENU. This screen appears to the user in two stages. First, the screen title block and a prompt for entering project release flow appear on the screen. Once a value for flow has been entered, the rest of the headwater boundary conditions appear on the screen. At that point, any or all of the data appearing may be changed.

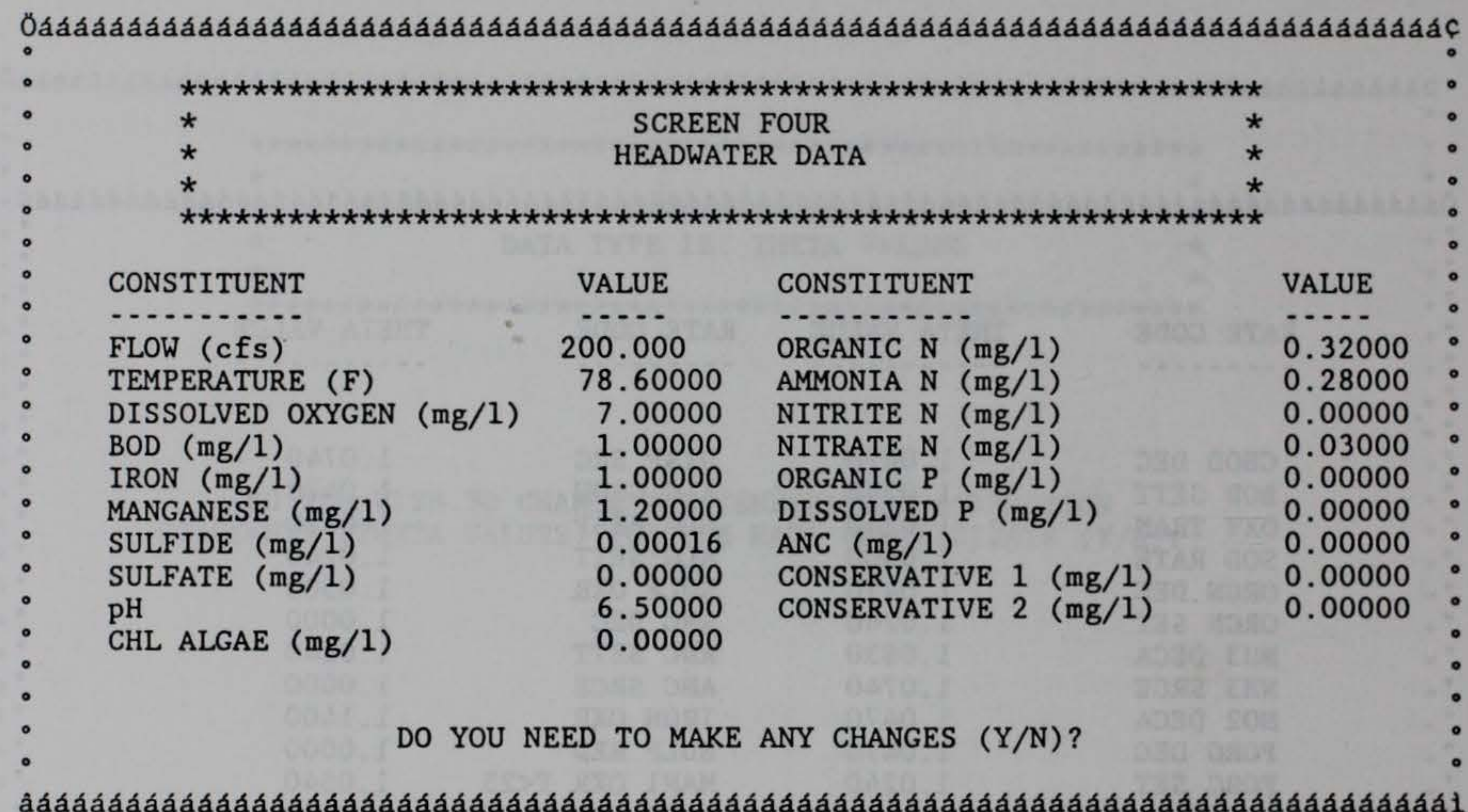

Figure B14. Headwater boundary conditions screen 
20. Following the headwater data screen is the data type 2, reach identification screen (Figure B15). Each reach may be given its own name (maximum of 15 characters), or the same name may be used for all. The value of the river kilometer or mile at the head of the reach must be greater than that at the end of the reach. This screen is repeated once for each reach. After the first reach, the river kilometer/mile at the head of the next reach is automatically set to the river kilometer/mile at the end of the previous reach and cannot be changed by the user.

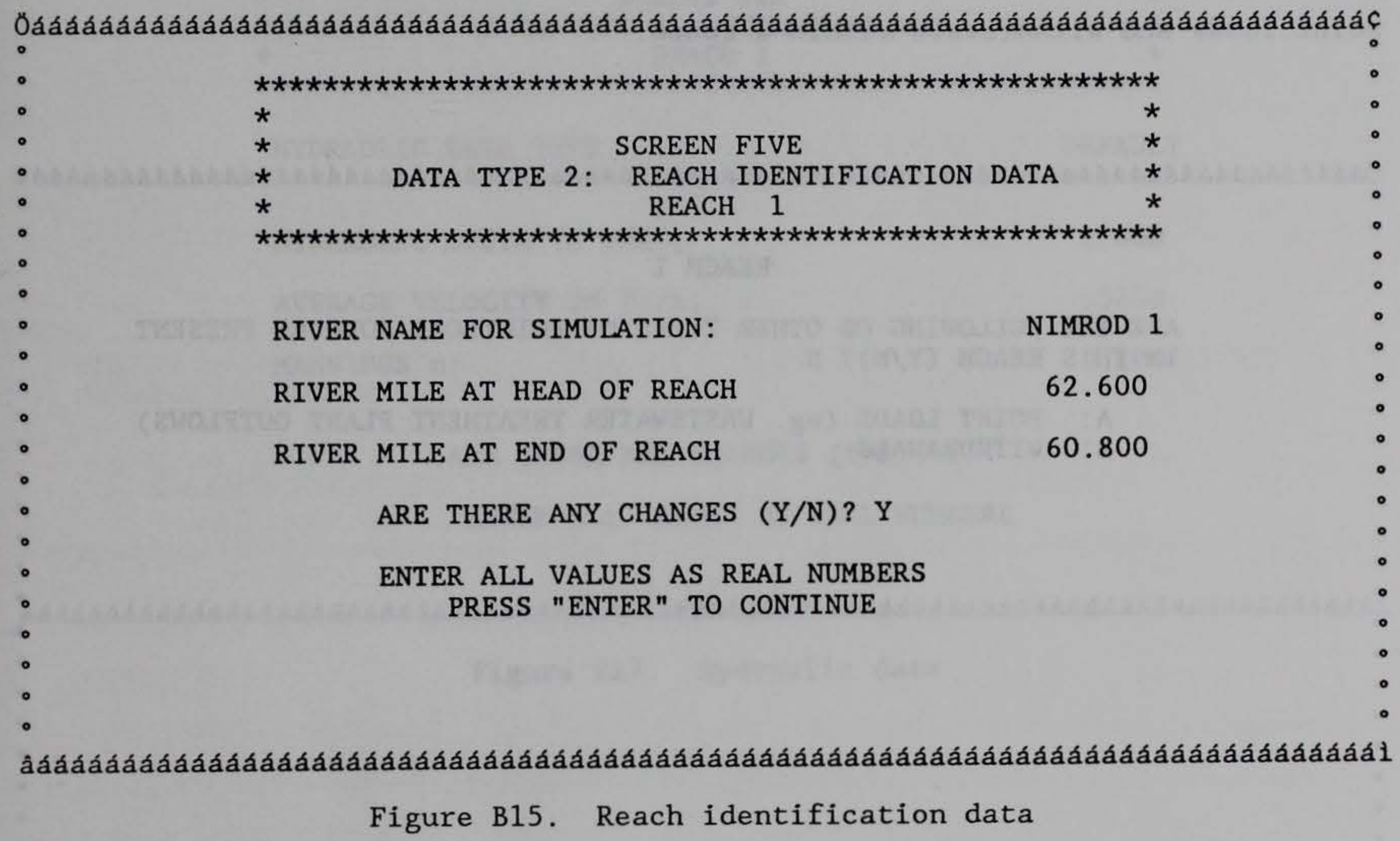


21. After screen 5, TWQI prompts the user for the number of point loads or withdrawals within that reach (Figure B16). This number cannot exceed the value entered earlier on the control data screen (Figure B11) for the total number of point loads and withdrawals. If it does, a warning flag informs the user that the number of point loads and withdrawals within this reach or the total number within all reaches has been exceeded and must be corrected.

22. Next, a prompt appears asking what is first from the upstream end of the reach, a point load (P) or withdrawal (W). After entering $P$ or $W$, prompts for the river kilometer/mile location of the point load or withdrawal and its identification name appear. These three steps are repeated for all point loads and withdrawals within a reach.

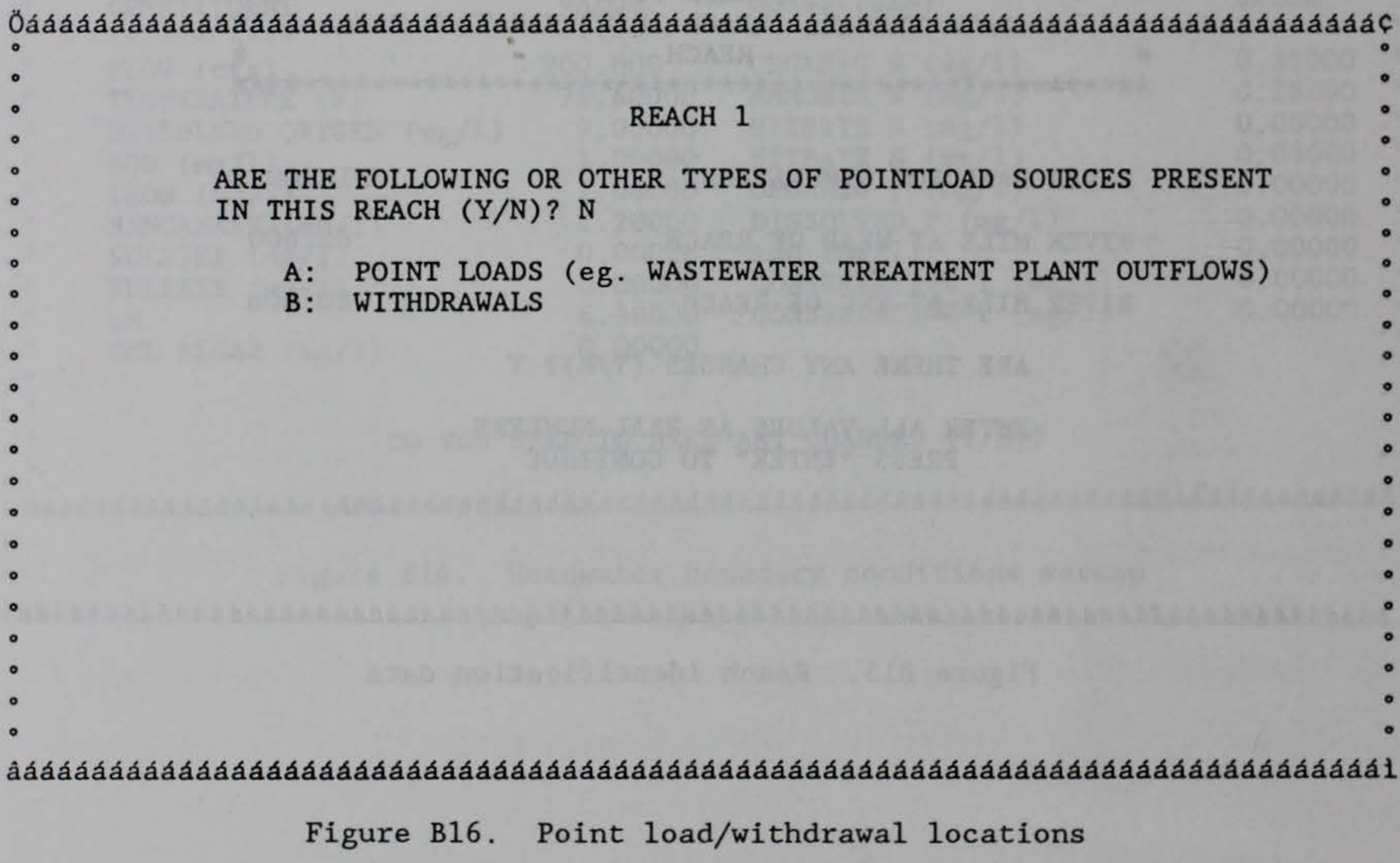


23. Screen 6 (Figure B17) contains the hydraulic data (such as depth, velocity, and Manning's $n$ ) for this reach. Values must be entered for all three hydraulic variables. If multiple reaches are simulated, the values for the previous reach are displayed as the defaults of the current reach. These values can be selected by simply pressing ENTER, or new values may be entered.

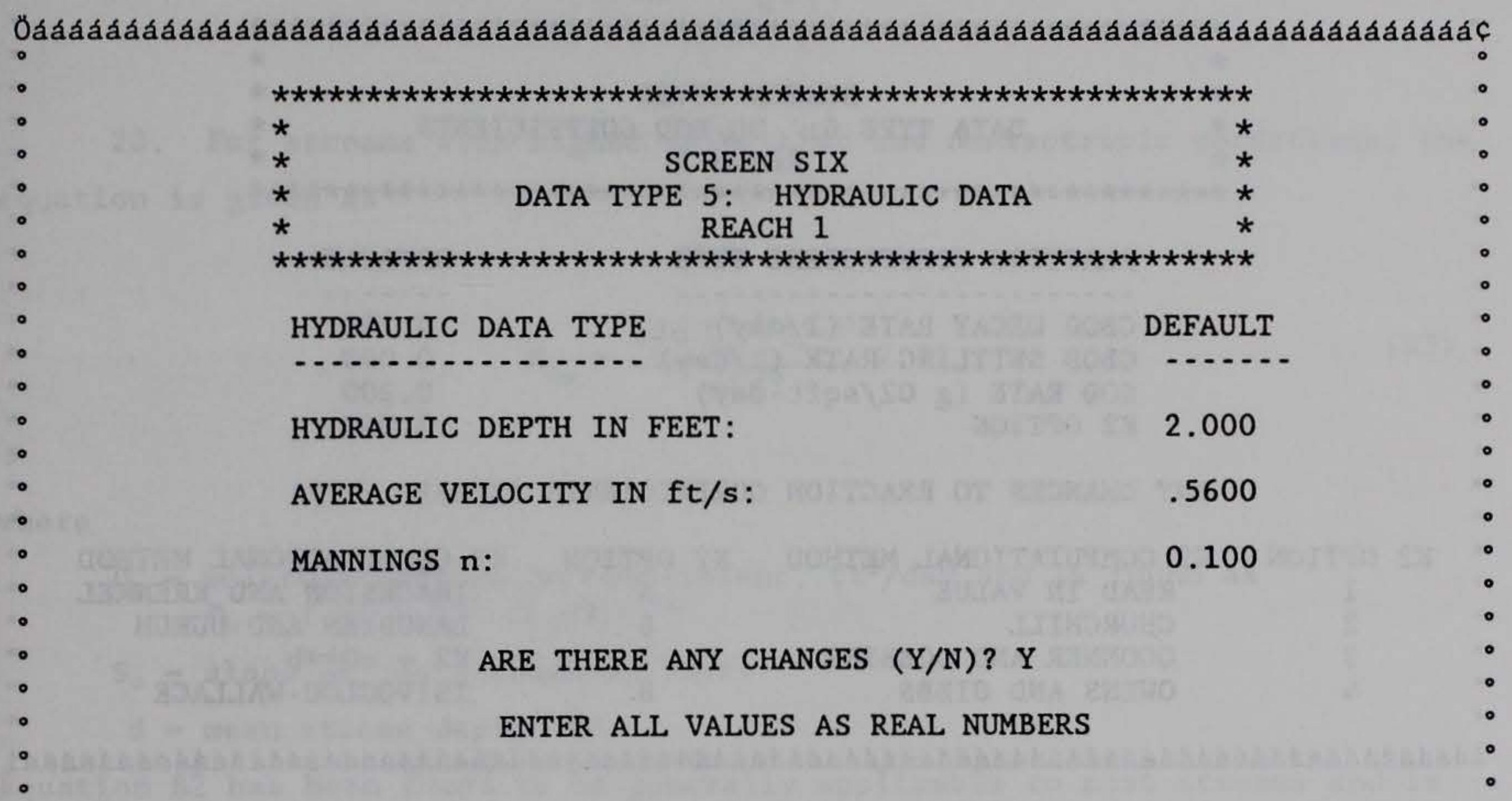

âááááááááááááááááááááááááááááááááááááááááááááááááááááááááááááááááááál

Figure B17. Hydraulic data 
24. Coefficients for DO/BOD used by TAILWTR are listed on screen 7 (Figure B18). Also listed are choices for the method of calculating the reaeration coefficient $K_{2}$. TWQM provides the same eight options as QUAL2E (Brown and Barnwell 1987), allowing the user to select estimation or reading in of $K_{2}$ values. These options are as follows:

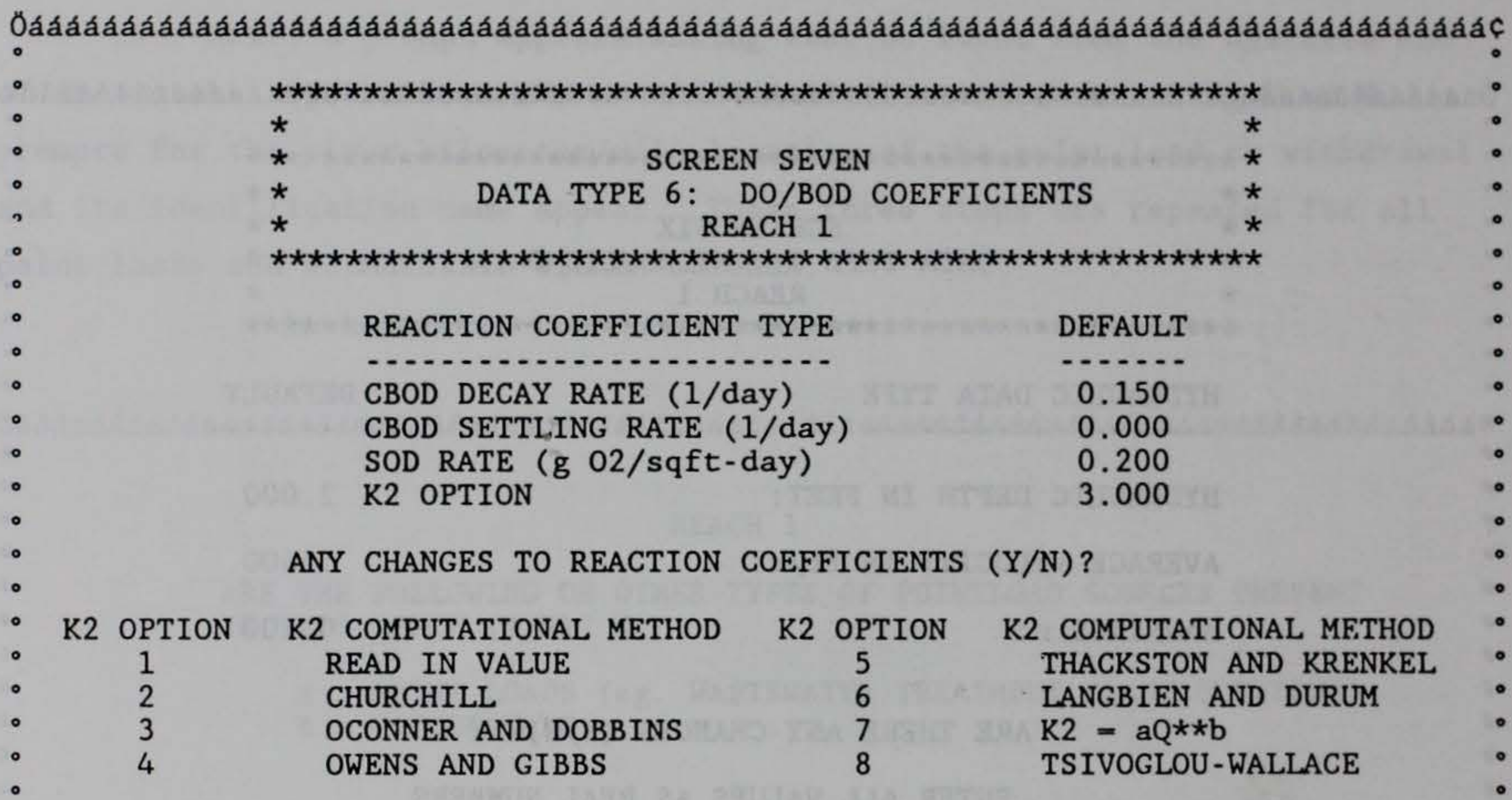

âáááááááááááááááááááááááááááááááááááááááááááááááááááááááááááááááááááái

Figure B18. DO/BOD coefficients

\section{$\underline{\mathrm{K}}_{2}$ Option 1}

25. Option 1 allows the user to read in estimated or measured $K_{2}$ values.

$\underline{\mathrm{K}}_{2}$ Option 2

26. Churchill, Elmore, and Buckingham (1962) developed the following equation for $\mathrm{K}_{2}$ at $20{ }^{\circ} \mathrm{C}$ based on measured stream reaeration data.

$$
\mathrm{K}_{2_{20}}=5.026 \overline{\mathrm{u}}^{0.969} \mathrm{~d}^{-1.673} 2.31
$$

where

$$
\begin{aligned}
\mathrm{K}_{2} & =\text { reaeration coefficient, } 1 / \text { day } \\
\overline{\mathrm{u}} & =\text { average stream velocity, ft/sec } \\
\mathrm{d} & =\text { average stream depth, ft }
\end{aligned}
$$




\section{$\underline{K}_{2}$ Option 3}

27. O'Connor and Dobbins (1958) proposed equations based on the turbulence characteristics of a stream. For streams that have low velocities and isotropic conditions, the equation is given as

$$
K_{20}=\frac{\left(D_{m} \bar{u}\right)^{0.5}}{d^{1.5}}
$$

28. For streams with higher velocities and nonisotropic conditions, the equation is given as

$$
\mathrm{K}_{20}=\frac{480 \mathrm{D}_{\mathrm{m}}^{0.5} \mathrm{~S}_{\mathrm{o}}^{0.25}}{\mathrm{~d}^{1.25}} 2.31
$$

where

$\mathrm{D}_{\mathrm{m}}=$ molecular diffusion coefficient, $\mathrm{ft}^{2} /$ day and is found as $\mathrm{D}_{\mathrm{m}}=1.91 \times 10^{3}(1.037)^{\mathrm{T}-20}$

$\mathrm{S}_{\mathrm{o}}=$ slope of the streambed, $\mathrm{ft} / \mathrm{ft}$

$\mathrm{d}=$ mean stream depth, ft

Equation B2 has been found to be generally applicable to most streams and is the default $\mathrm{K}_{2}$ option for TAILWTR.

$\underline{\mathrm{K}}_{2}$ Option 4

29. Owens, Edwards, and Gibbs (1964) estimated reaeration coefficients for shallow, fast-moving streams based on six streams in England. Combining their work with that of Churchill, Elmore, and Buckingham (1962), they developed an equation for streams having depths of 0.4 to $11.0 \mathrm{ft}$ and velocities of 0.1 to $5.0 \mathrm{ft} / \mathrm{sec}$. Their equation is written as

$$
K_{2_{20}}=\frac{9.4 \bar{u}^{0.67}}{d^{1.85}} 2.31
$$

where

$$
\begin{aligned}
& \bar{u}=\text { mean velocity, ft/sec } \\
& d=\text { mean depth, ft }
\end{aligned}
$$




\section{$\underline{\mathrm{K}}_{2} \quad$ Option 5}

30. Thackston and Krenkel (1966) proposed the following equation based on their investigation of several rivers in the Tennessee Valley Authority system.

$$
K_{2_{20}}=10.8\left(1+F^{0.5}\right) \frac{u_{*}}{d} 2.31
$$

where $F$ is the Froude number, which is given by

$$
F=\frac{u_{*}}{\sqrt{g d}}
$$

and $u_{*}$ is the shear velocity (ft/sec) given by

$$
u_{*}=\sqrt{\mathrm{dS}_{\mathrm{e}} \mathrm{g}}=\frac{\overline{\mathrm{un}} \sqrt{\mathrm{g}}}{1.49 \mathrm{~d}^{1.167}}
$$

where

$\mathrm{d}=$ mean depth, ft

$\mathrm{S}_{e}=$ slope of the energy gradient

$\mathrm{g}=$ acceleration of gravity, $\mathrm{ft} / \mathrm{sec}^{2}$

$\overline{\mathrm{u}}=$ mean velocity, $\mathrm{ft} / \mathrm{sec}$

$\mathrm{n}=$ Manning's coefficient

$\underline{\mathrm{K}}_{2}$ Option 6

31. Langbien and Durum (1967) developed a formula for $\mathrm{K}_{2}$ at $20{ }^{\circ} \mathrm{C}$ :

$$
\mathrm{K}_{2 \mathrm{o}}=3.3 \frac{\overline{\mathrm{u}}}{\mathrm{d}^{1.33}} 2.31
$$


where

$\overline{\mathrm{u}}=$ mean velocity, $\mathrm{ft} / \mathrm{sec}$

$\mathrm{d}=$ mean depth, ft

$\underline{\mathrm{K}}_{2} \quad$ Option 7

32. Option 7 computes the reaeration coefficient from a power function of flow and is given by

$$
\mathrm{K}_{2}=\mathrm{aQ}^{\mathrm{b}}
$$

where

$a=$ coefficient of flow for $K_{2}$

$\mathrm{Q}=\mathrm{flow}, \mathrm{ft}^{3} / \mathrm{sec}$

$\mathrm{b}=$ exponent on flow for $\mathrm{K}_{2}$

$\underline{\mathrm{K}}_{2}$ Option 8

33. Tsivoglou and Wallace (1972) based their method on the assumption that the reaeration coefficient for a reach is proportional to the change in elevation of the water surface in the reach and inversely proportional to the flow time through the reach. Their equation is written as

$$
K_{2_{20}}=c \frac{\Delta h}{t_{f}}
$$

where

$c=$ escape coefficient, $1 / \mathrm{ft}$

$\Delta \mathrm{h}=$ change in water surface elevation in reach, $\mathrm{ft}$

$t_{f}=$ flow time through reach, days

34. Assuming uniform flow, the change in water surface elevation is

$$
\Delta \mathrm{h}=\mathrm{S}_{\mathrm{e}} \Delta \mathrm{x}
$$

where

$\mathrm{S}_{\mathrm{e}}=$ slope of energy gradient, $\mathrm{ft} / \mathrm{ft}$

$\Delta \mathrm{x}=$ reach length, ft

and the flow time through the reach is 


$$
t_{f}=\frac{\Delta x}{\bar{u}}
$$

where $\bar{u}$ is the mean velocity in the reach $(\mathrm{ft} / \mathrm{sec})$.

35. Substituting Equations $\mathrm{B} 11$ and B12 into B10 gives

$$
\mathrm{K}_{2_{20}}=(3,600 \times 24) \mathrm{cS}_{\mathrm{e}} \overline{\mathrm{u}}
$$

36. Equation $\mathrm{B} 13$ is the formula used for Option 8 in TAILWTR.FOR. The constants 3,600 and 24 convert velocity to units of feet per day. The slope is input directly for computing $\mathrm{K}_{2}$ with this option. The escape coefficient can be estimated based on recommendations of TenEch (1978) using

$$
\begin{aligned}
& c=0.054 \mathrm{ft}^{-1}\left(\text { at } 20{ }^{\circ} \mathrm{C}\right) \text { for } 15 \leq \mathrm{Q} \leq 3,000 \mathrm{ft}^{3} / \mathrm{sec} \\
& \mathrm{c}=0.110 \mathrm{ft}^{-1}\left(\text { at } 20{ }^{\circ} \mathrm{C}\right) \text { for } 1 \leq \mathrm{Q} \leq 15 \mathrm{ft}^{3} / \mathrm{sec}
\end{aligned}
$$

37. Any of the methods listed can be selected by entering their corresponding number (real number). If $K_{2}$ option 1,7 , or 8 is selected, TWQI will prompt the user to input the appropriate coefficients or values. 
38. Screen 8 (Figure B19) contains coefficients for nutrient removal kinetics. The removal rate for ammonia oxidation can be specified or determined by TAILWTR by entering $a^{\prime}-1 .^{\prime}$ in place of an actual value. The word 'modeled' will appear on the screen (Figure B19) for ammonia oxidation to indicate that the user chose for TAILWTR to calculate the rate. All other rates on this screen are set to default values if no changes are made or specified by the user. Default values for all the rates are average values of the ranges specified by the QUAL2E manual (Brown and Barnwel1 1987).

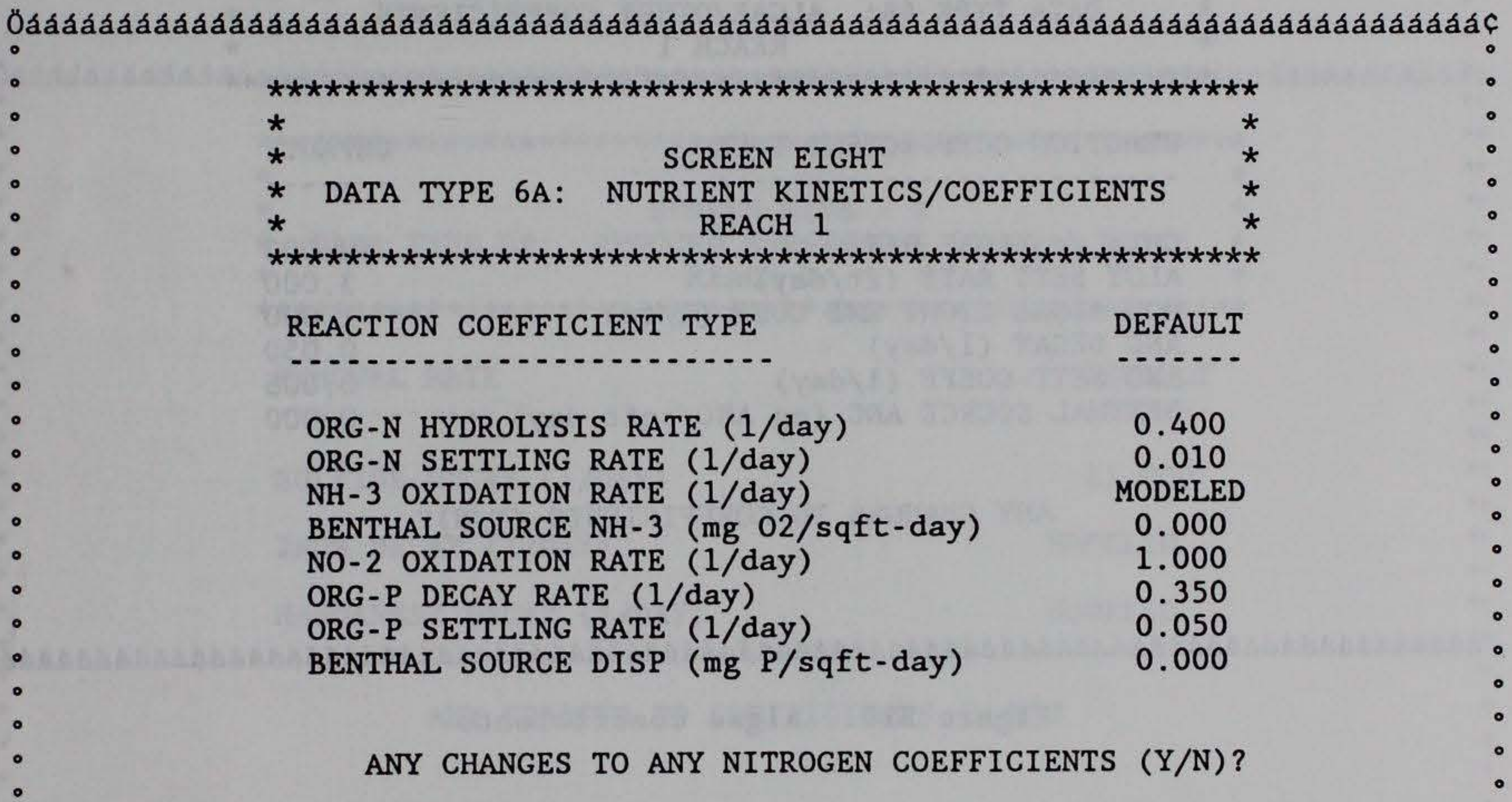

âááááááááááááááááááááááááááááááááááááááááááááááááááááááááááááááááááái

Figure B19. Nutrient kinetics 
39. Screen 9 (Figure B20) contains values for coefficients for algae and the arbitrary nonconservative constituents. Default values were obtained from ranges recommended in the QUAL2E manual (Brown and Barnwell 1987). If any changes are made to these values, the new value should have units that are consistent with those shown.

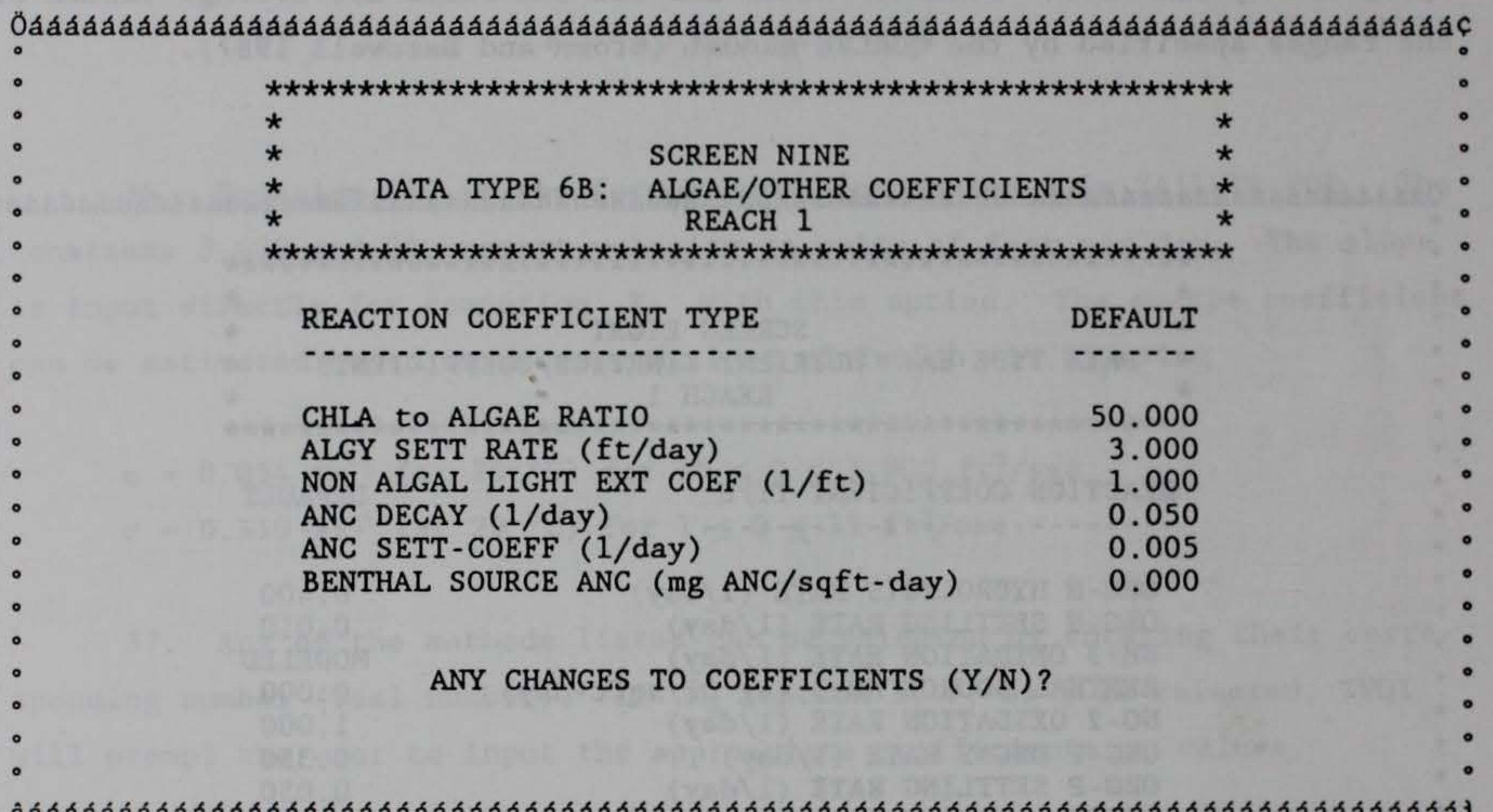

âáááááááááááááááááááááááááááááááááááááááááááááááááááááááááááááááááa

Figure B20. Algae coefficients 
40. Screen 9A (Figure B21) contains removal rate values for the three reduced substances modeled: sulfide, iron, and manganese. New removal rates may be entered for one or all reduced substances, or TAILWTR can determine their removal rates (except for sulfide). New removal rates are entered in the same manner as other data in previous screens. To have TAILWTR determine the removal rate of a substance, answer yes ( $Y$ ) when asked if there are any changes. As with ammonia oxidation, enter a -1 . for the removal rate of the substance whose removal rate is to be modeled. The word 'modeled' will appear on the screen in place of an actual value for iron/manganese decay whenever a -1 . was entered as the removal rate.

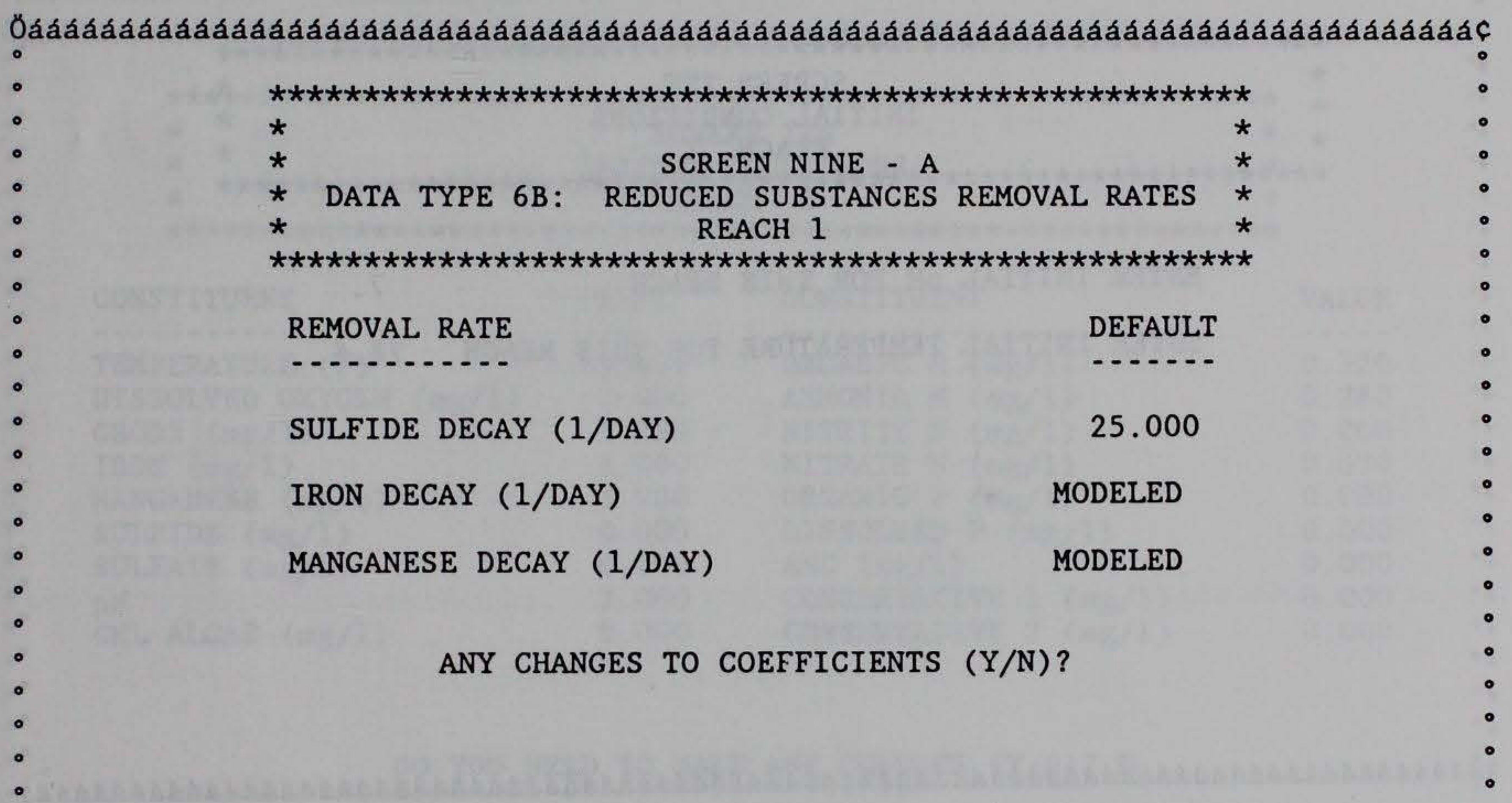

âáááááááááááááááááááááááááááááááááááááááááááááááááááááááááááááááááál

Figure B21. Reduced substances removal rates 
41. Screen 10 actually appears in two screens and only for simulations where temperature is not being modeled. This screen contains information on the initial conditions in a reach. First, the initial pH and temperature of the reach are entered (Figure B22). Initial values for the other constituents are set equal to their headwater boundary conditions and then displayed with the $\mathrm{pH}$ and temperature values on the second screen 10 (Figure B23). If desired, changes can be made to any of the initial condition values at this time. However, changes to any variables besides temperature and $\mathrm{pH}$ will not impact the model results since a steady state solution is obtained.

Őaáááááááááááááááááááááááááááááááááááááááááááááááááááááááááááááááááạ

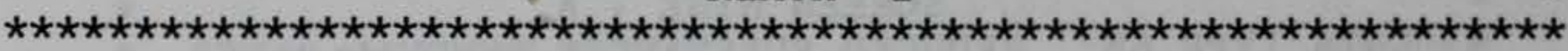

ENTER INITIAL PH FOR THIS REACH

7.

ENTER INITIAL TEMPERATURE FOR THIS REACH $\quad 78.6$

âááááááááááááááááááááááááááááááááááááááááááááááááááááááááááááááááááá1 Figure B22. Initial conditions, Part 1 


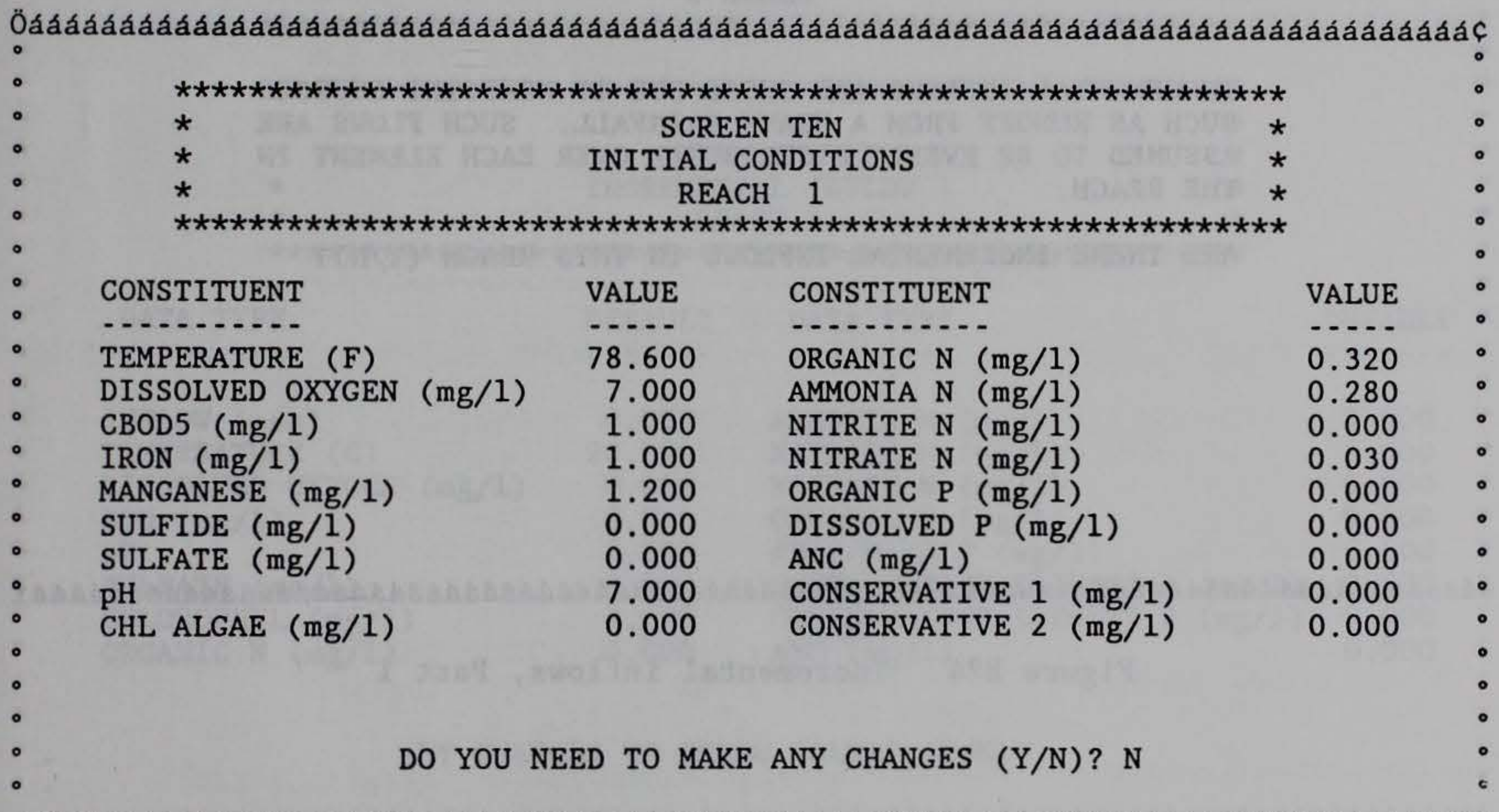

âááááááááááááááááááááááááááááááááááááááááááááááááááááááááááááááááááááa .

Figure B23. Initial conditions, Part 2 
42. Screen 11 (incremental inflows) is just like screen 10 in that it appears in two parts. The first of the screens contains information describing incremental inflows (Figure B24) and asks if there are any in this reach. If there are no incremental inflows in a reach, the user answers no (N). If yes (Y) is selected, the second screen will appear, and constituent values for incremental inflow can be entered (Figure B25).

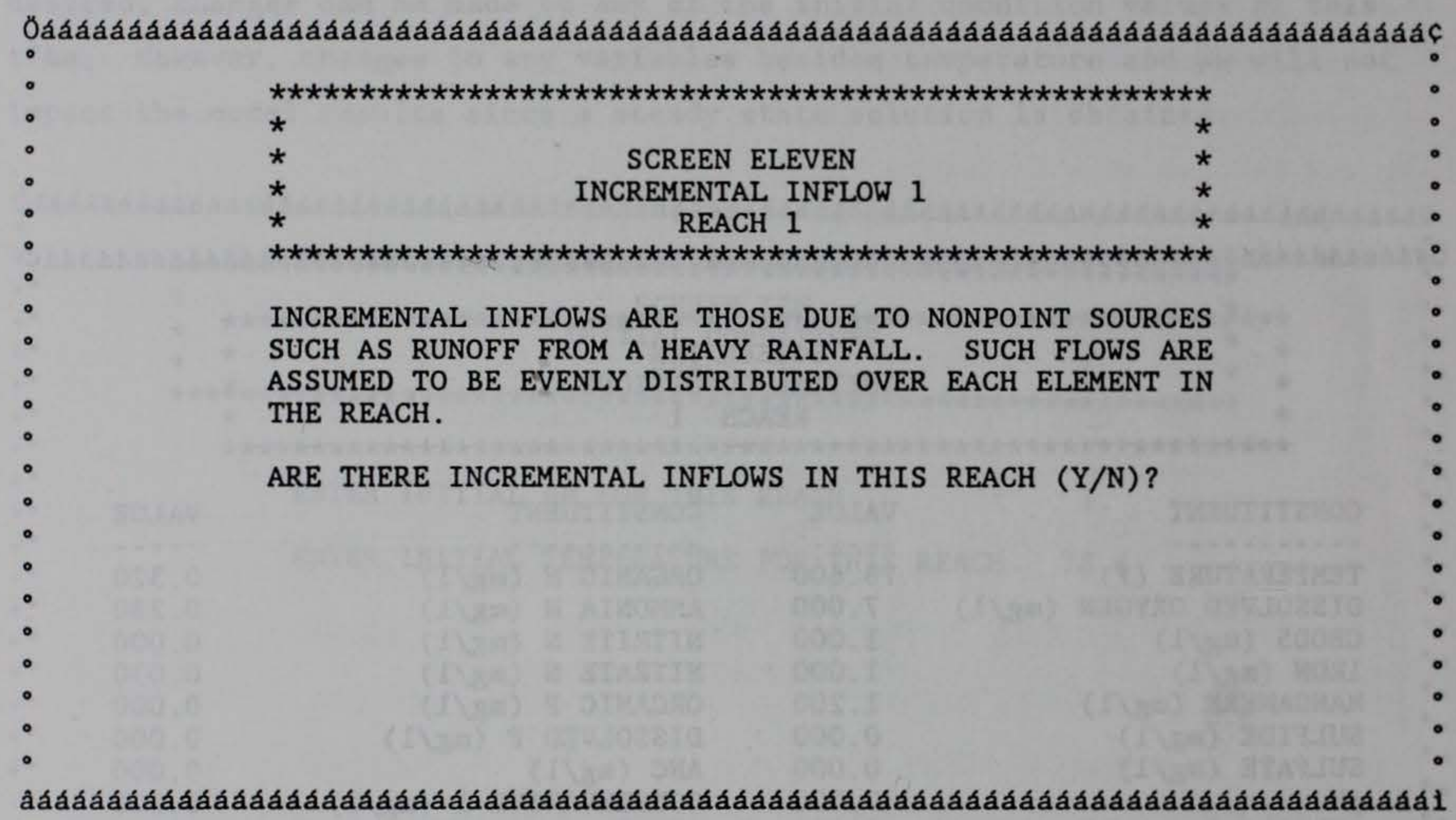

Figure B24. Incremental inflows, Part 1 


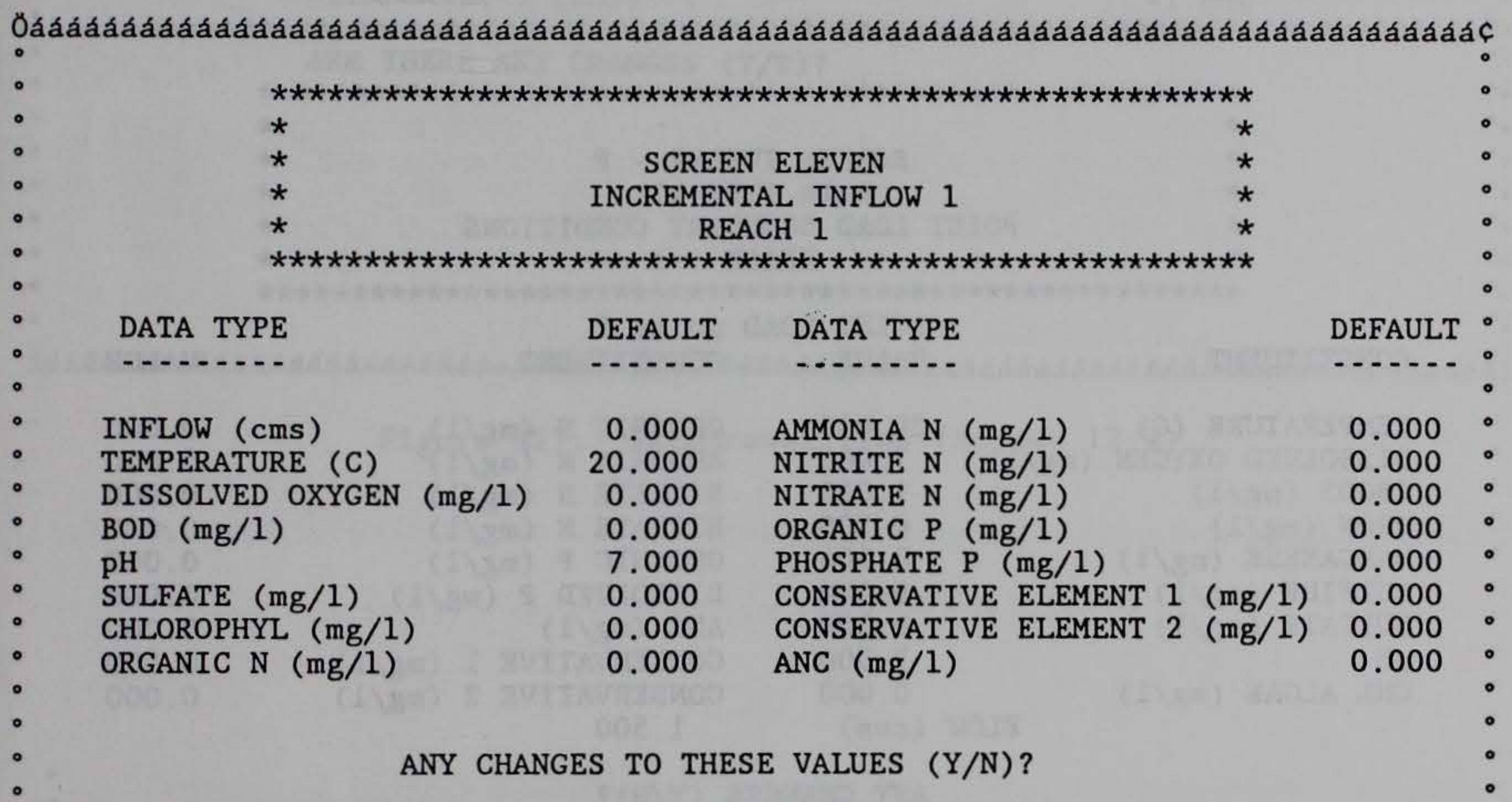

âááááááááááááááááááááááááááááááááááááááááááááááááááááááááááááááááááái

Figure B25. Incremental inflows, Part 2 
43. After finishing with screen 11, TWQI returns to screen 5 (Figure B15) if more than one reach is being modeled. Screens 5 through 11 will be repeated once for each additional reach. After finishing the last reach, screens 12-P (Figure B26) and 12-W (Figure B27) will appear only if there are point loads or withdrawals. These screens will appear in the order in which the point loads and withdrawals occur downstream from the headwater. The screen for point loads (Figure B26), 12-P, is very similar to that for the headwater data (Figure B14). It appears once for each point load, and concentration values for all water quality constituents selected to be modeled can be entered.

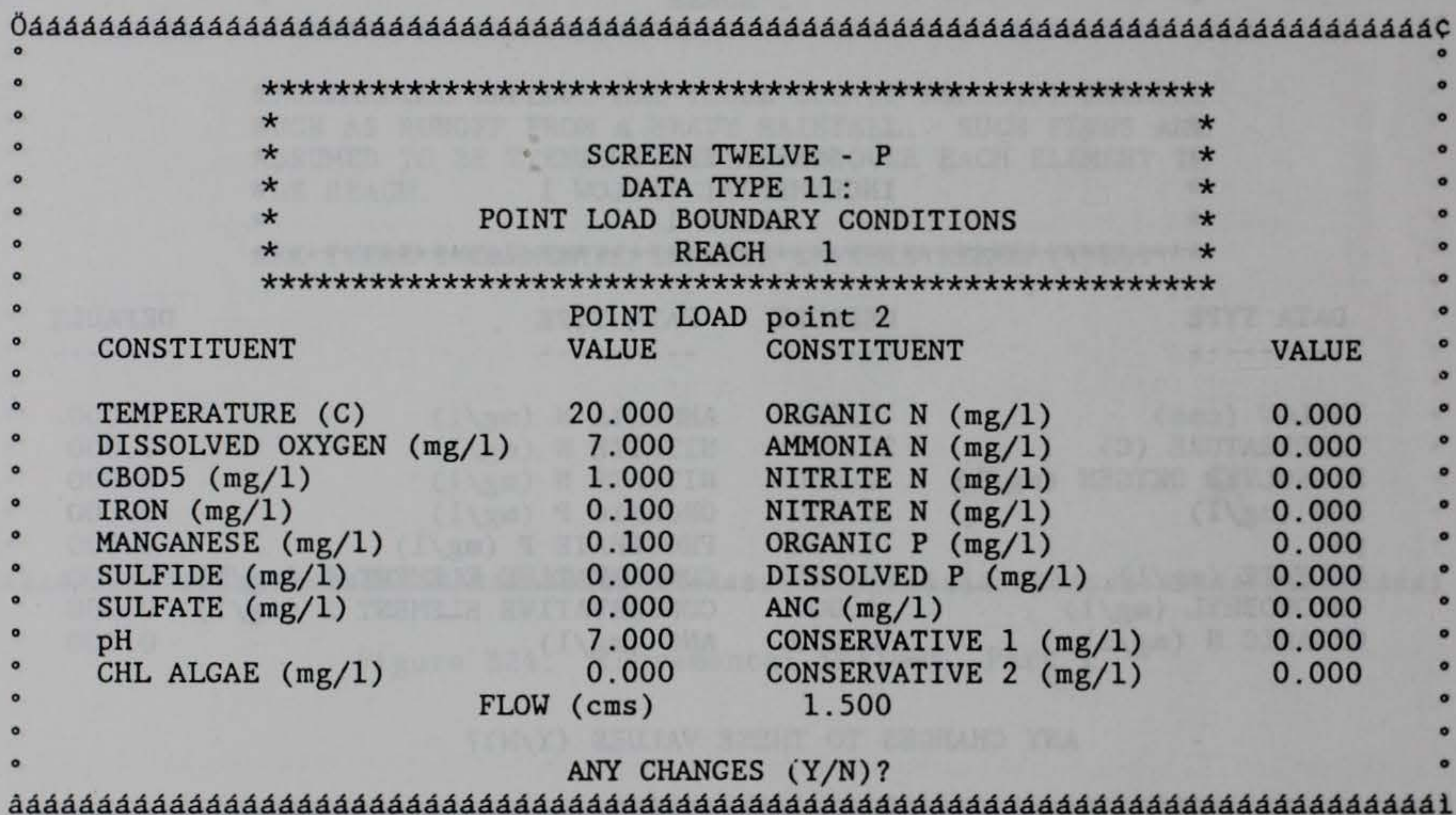

Figure B26. Point load boundary conditions (screen 12-P) 
44. The only information required on screen $12-\mathrm{W}$ is the withdrawal flow. This value must be entered as a negative real number.

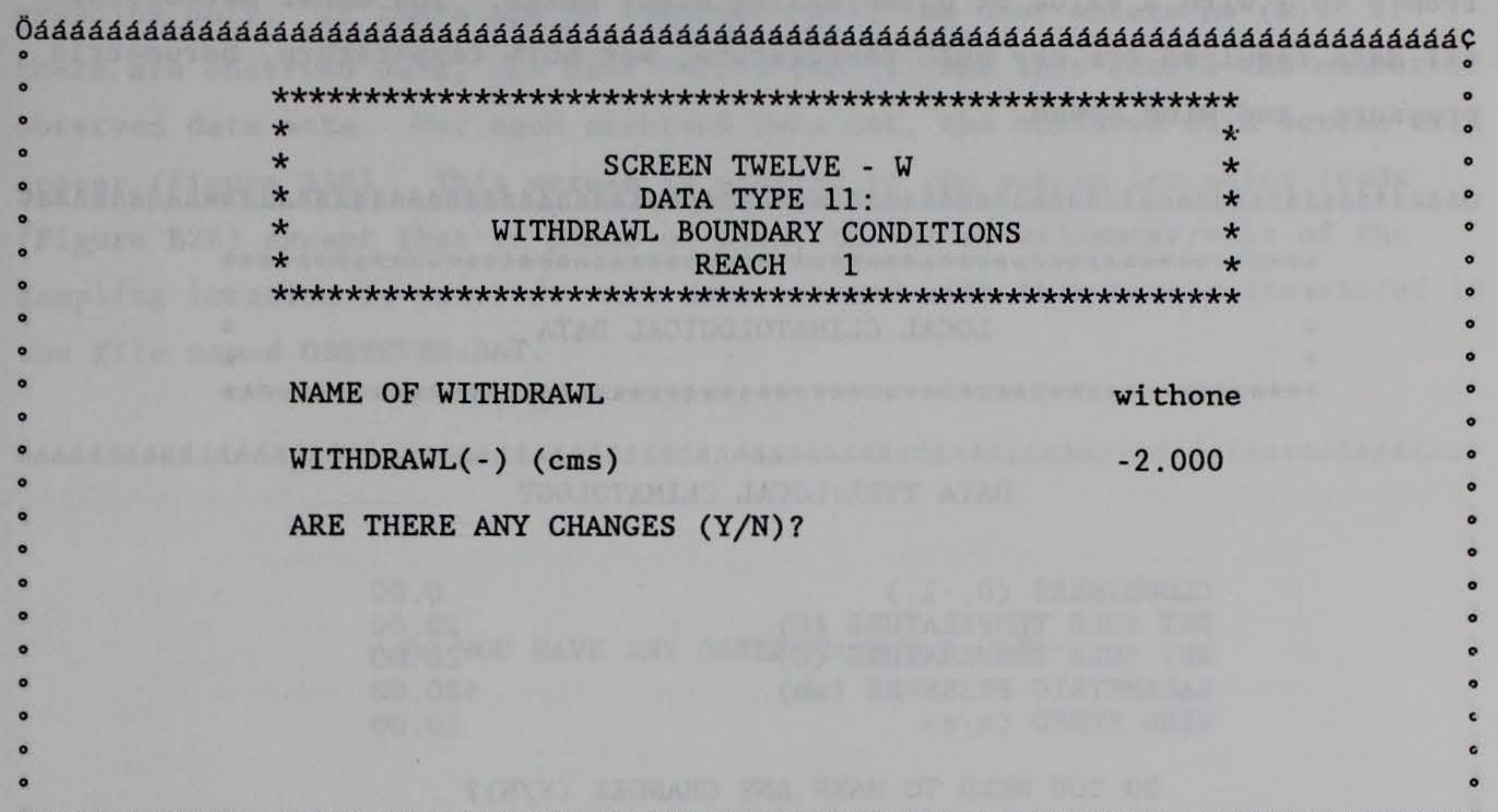

âááááááááááááááááááááááááááááááááááááááááááááááááááááááááááááááááááái

Figure B27. Withdrawal flow (screen 12-W) 
45. A screen containing local climatological data will appear only when temperature is being modeled (Figure B28). The cloudiness scale has a range from 0 to 1 with a value of 0 indicating clear skies. The other meteorological data required are dry bulb temperature, wet bulb temperature, barometric pressure, and wind speed.

¿áááááááááááááááááááááááááááááááááááááááááááááááááááááááááááááááááááç

DATA TYPE: LOCAL CLIMATOLOGY
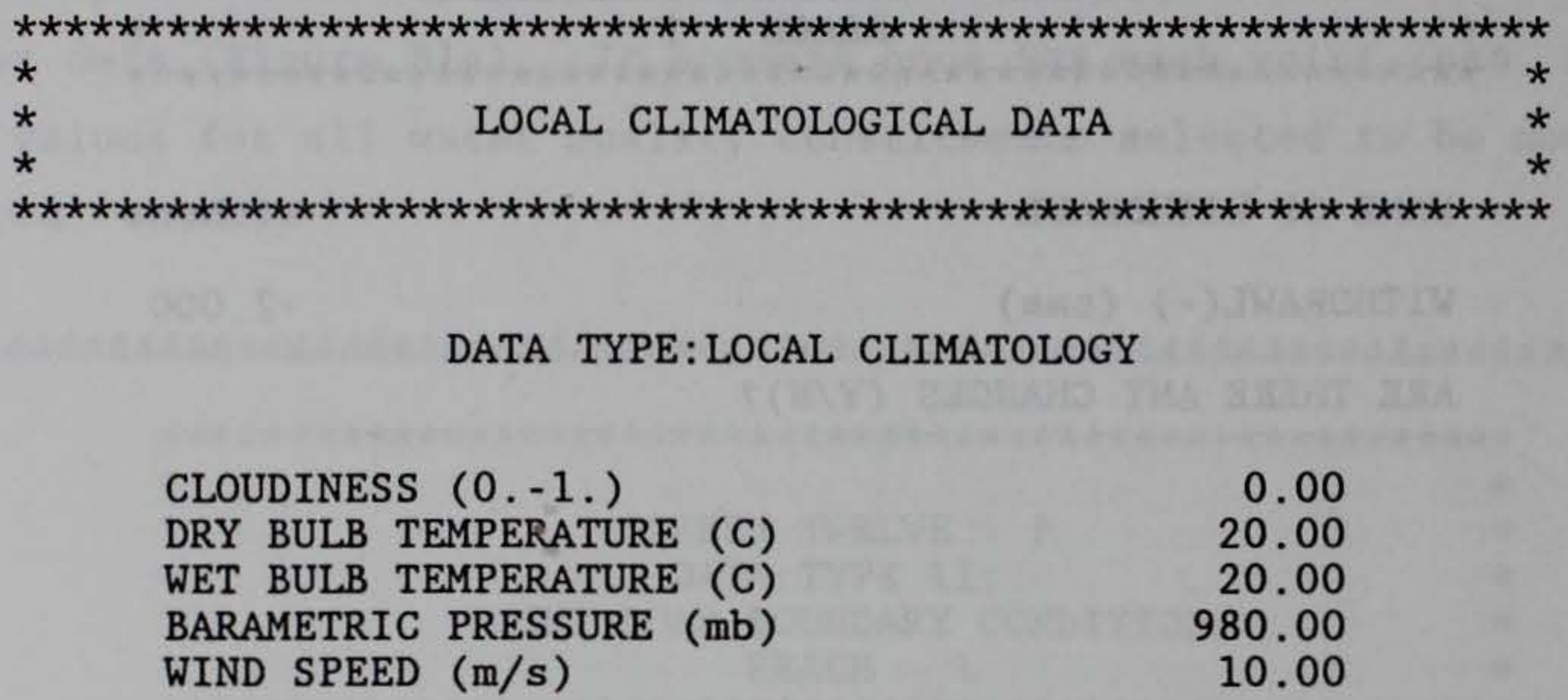

0.00

20.00

20.00

980.00

WIND SPEED $(\mathrm{m} / \mathrm{s})$

10.00

DO YOU NEED TO MAKE ANY CHANGES $(\mathrm{Y} / \mathrm{N})$ ?

Figure B28. Local climatological data 
46. The next screen deals with observed data (Figure B29) at stations in the study reach. This is optional, and the data entered are used for graphing only. If there are no observed data, the user enters no (N). If there are observed data, the user enters yes $(Y)$ and then enters the number of observed data sets. For each observed data set, the observed data screen will appear (Figure B30). This screen is similar to the screen for point loads (Figure B26) except that in place of flow, the river kilometer/mile of the sampling location is entered. All data entered with this screen are stored in the file named OBSERVED.DAT.

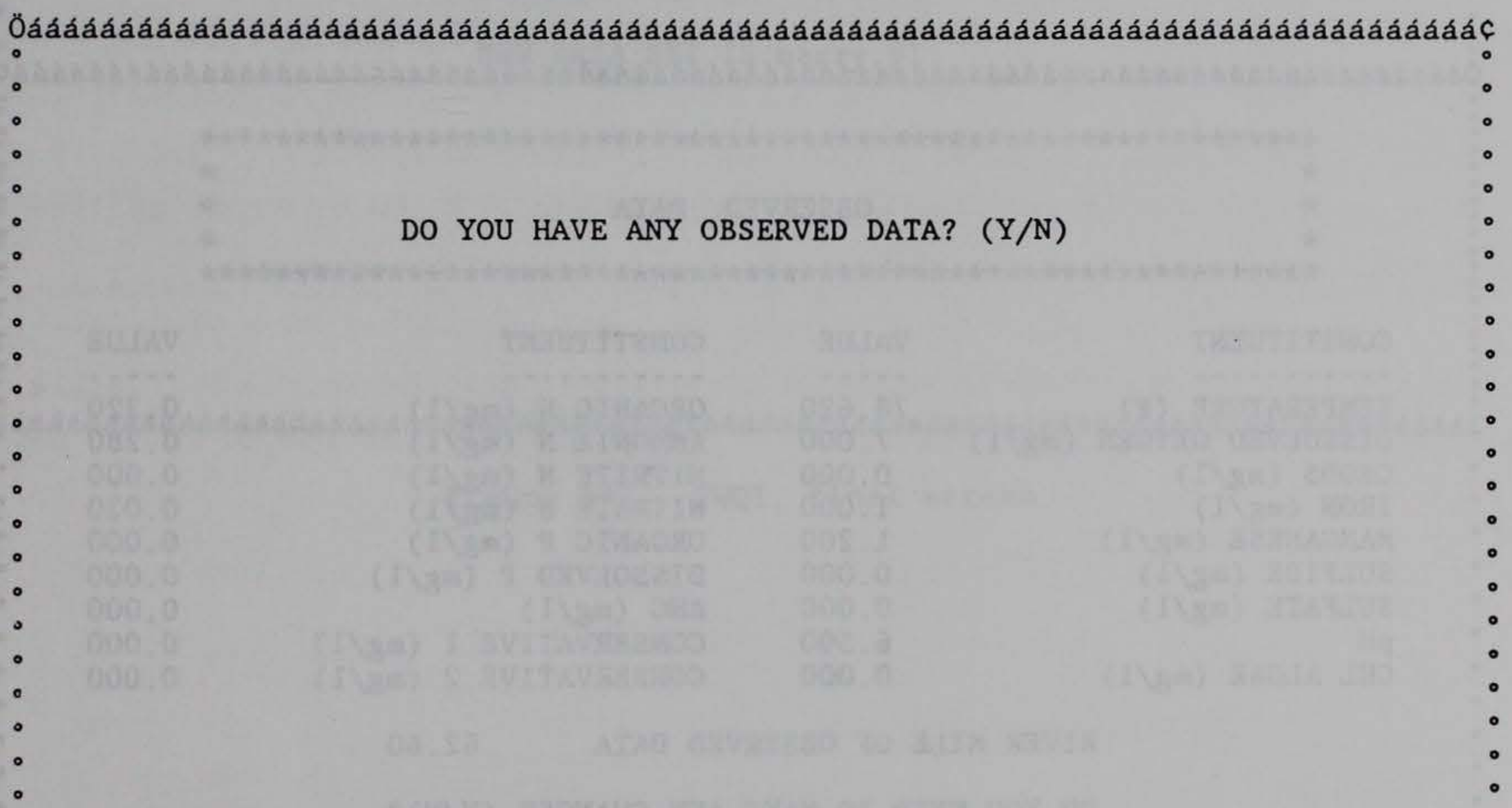

âaááááááááááááááááááááááááááááááááááaááááááááááááááááááááááááááááááál

Figure B29. Observed data, first screen 


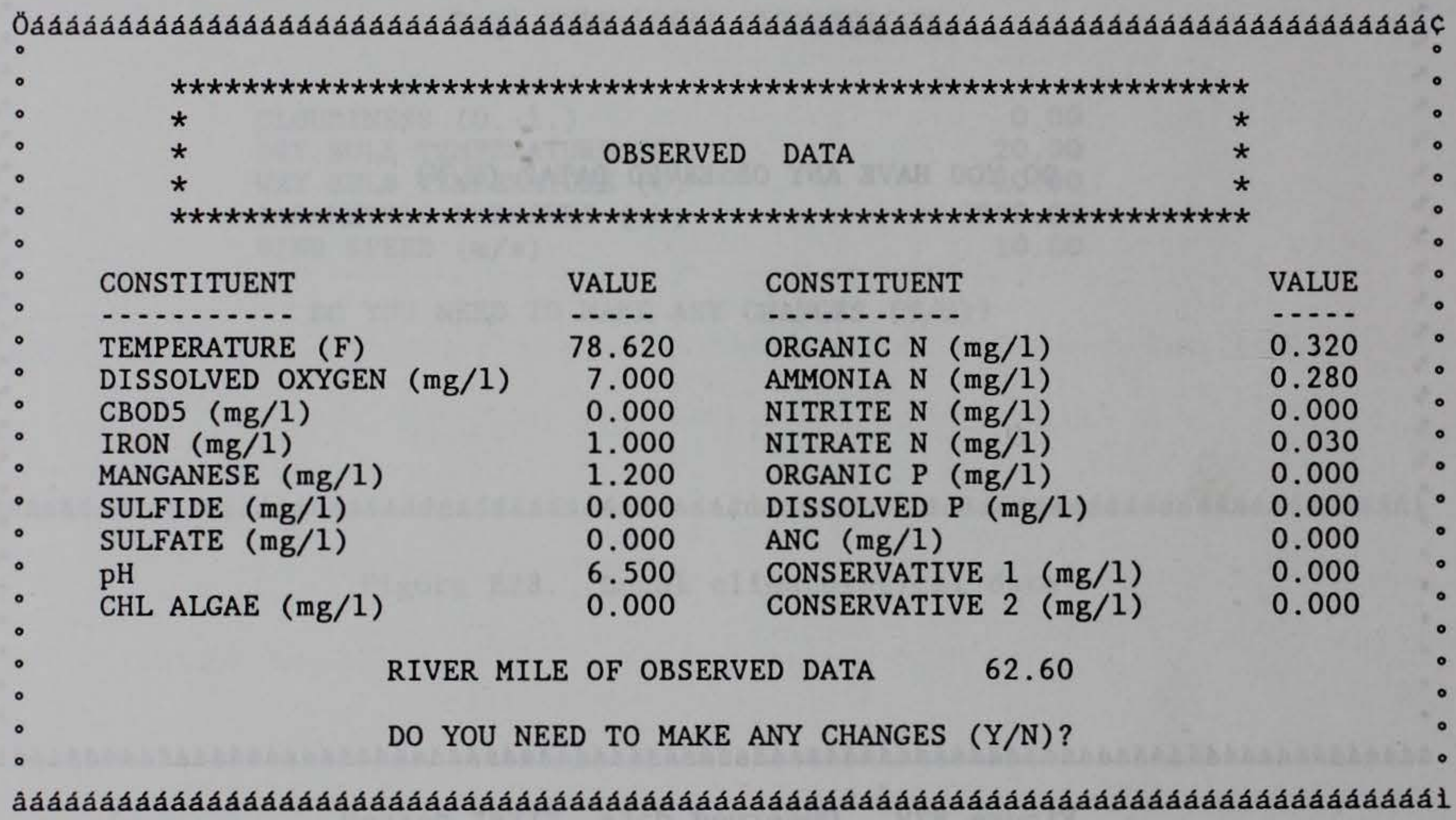

Figure B30. Observed data, input screen 
47. The final screen indicates that TWQI was completed successfully and displays the name of the data file that has just been created (Figure B31).

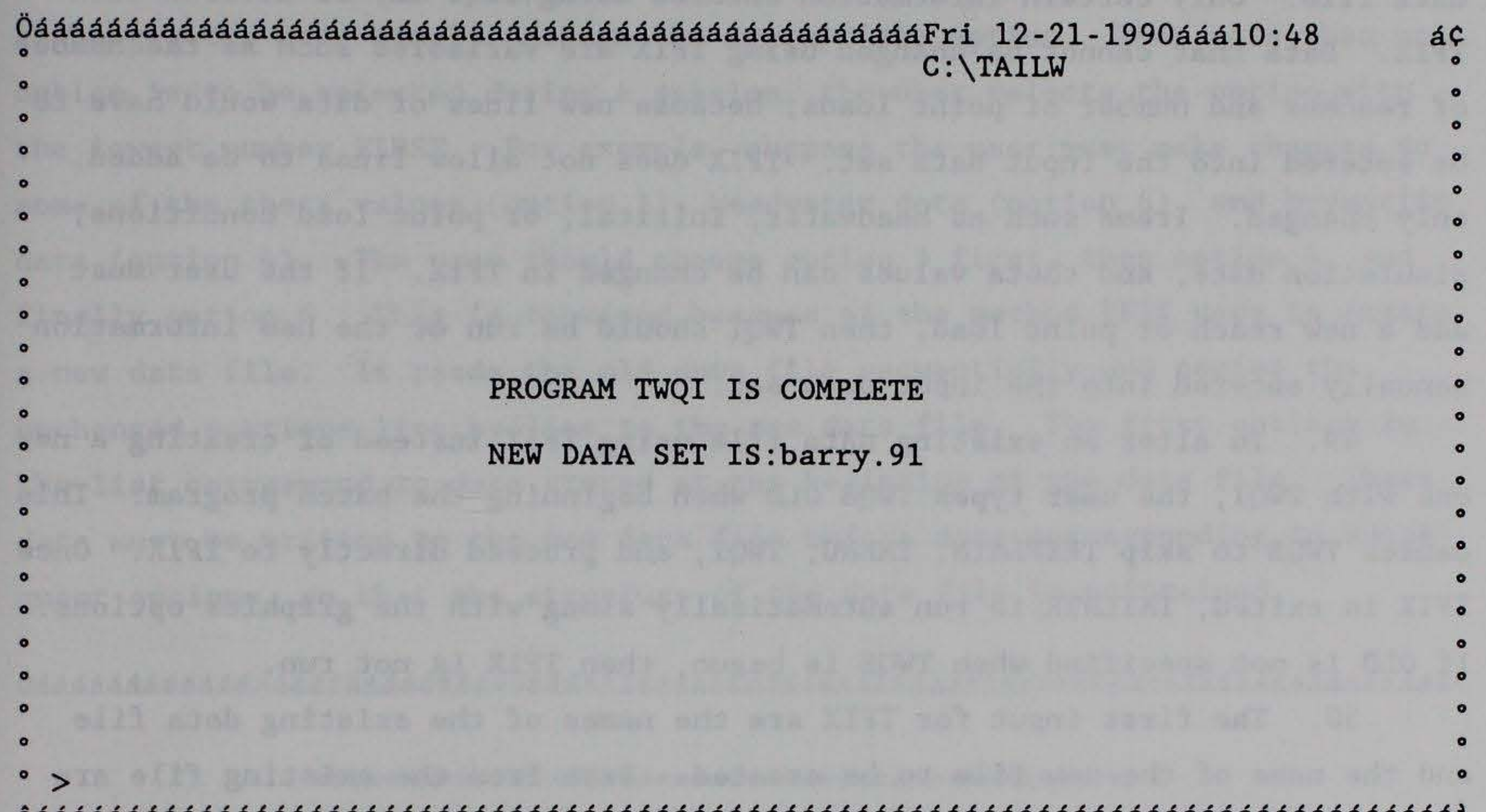

âáááááááááááááááááááááááááááááááááááááááááááááááááááááááááááááááááái

Figure B31. TWQI, final screen 


\section{Screens in TFIX. FOR}

48. TFIX allows the user to make changes to an existing TAILWTR input data file. Only certain information entered using TWQI may be altered with TFIX. Data that cannot be changed using TFIX are variables such as the number of reaches and number of point loads, because new lines of data would have to be entered into the input data set. TFIX does not allow lines to be added, only changed. Items such as headwater, initital, or point load conditions, simulation date, and theta values can be changed in TFIX. If the user must add a new reach or point load, then TWQI should be run or the new information manually entered into the input data set.

49. To alter an existing data file using TFIX instead of creating a new one with TWQI, the user types TWQB OLD when beginning the batch program. This causes TWQB to skip TEXPLAIN, TMENU, TWQI, and proceed directly to TFIX. Once TFIX is exited, TAILWTR is run automatically along with the graphics options. If OLD is not specified when TWQB is begun, then TFIX is not run.

50. The first input for TFIX are the names of the existing data file and the name of the new file to be created. Data from the existing file are read, and can be altered if necessary. These data are then stored in the new data file. 
51. TFIX next displays a screen that contains nine options (Figure B32). The first eight options correspond to different portions of the TAILWTR input data file that are to be changed. The ninth option exits TFIX. To make a change, the user simply selects the appropriate option. When more than one option is to be selected during a session, the user selects the option with the lowest number FIRST. For example, suppose the user must make changes to some of the theta values (option 3), headwater data (option 6), and hydraulic data (option 4). The user should choose option 3 first, then option 4, and finally option 6 . This is required because of the method TFIX uses to create a new data file. It reads the old data file sequentially and copies the unchanged portions line by line to the new data file. The first options in the list correspond to data stored at the beginning of the data file. These data must be written to the new data file before data corresponding to subsequent options, so that the structure of the data file is maintained.

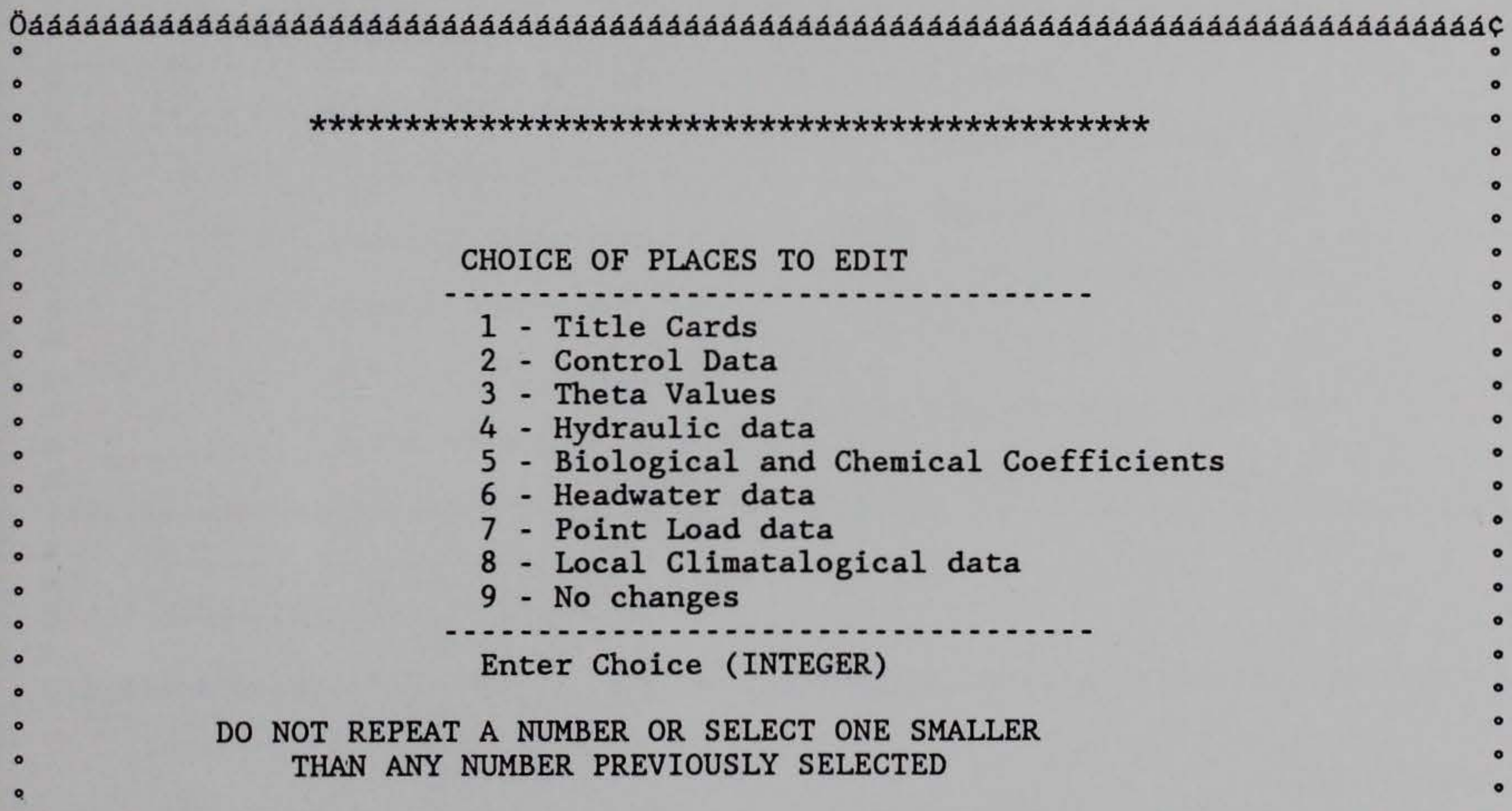

âáááááááááááááááááááááááááááááááááááááááááááááááááááááááááááááááááái

Figure B32. TFIX options screen 
52. Each of the first eight options has its own screen. The cursor will go to each item on the screen. The user makes changes by entering the new value when the cursor is in the appropriate place. To accept the value shown, the user presses the ENTER key. None of these screens allows the user to go back and make changes if mistakes were made entering new values. TFIX will have to be rerun to correct a mistake. 


\section{Screens in TAILWTR. FOR}

53. TAILWTR requires only the name of the input data file and the name of the output file. The input data file will usually be the data file just created by TWQI. However, the name of any old input data file can be entered. There are three options concerning output. It can be written to the screen, written directly to a printer, or written to a file. The final option is suggested due to the volume of output generated. To have the output written to a file, enter the name of the output file at the prompt concerning the output device. The name of the file can be up to eight characters long with an extension of three characters.

54. When running, TAILWTR will print messages to the screen indicating what tasks are being performed. If desired, these messages can be turned off by answering no (N) when asked about the run time messages. 
55. Graphical routines have been developed for TWQM output using GRAPHER and TPLOT software. A copy of one of these is required in order to use these graphics routines. After TAILWTR has finished, a screen will appear listing the graphing and plotting options along with options to exit TWQM or return to its beginning (Figure B33). Viewing (Figure B33) a graph means that the graph will appear on the screen, and plotting (Figure B33) a file means that the graph can be plotted using an HP Series II-compatible laser jet printer. If one of the options corresponding to viewing or plotting is selected, a screen containing a list of the different constituents that can be viewed or plotted will appear (Figure B34). To plot or view graphs of TAILWTR output data, the user selects the appropriate option.

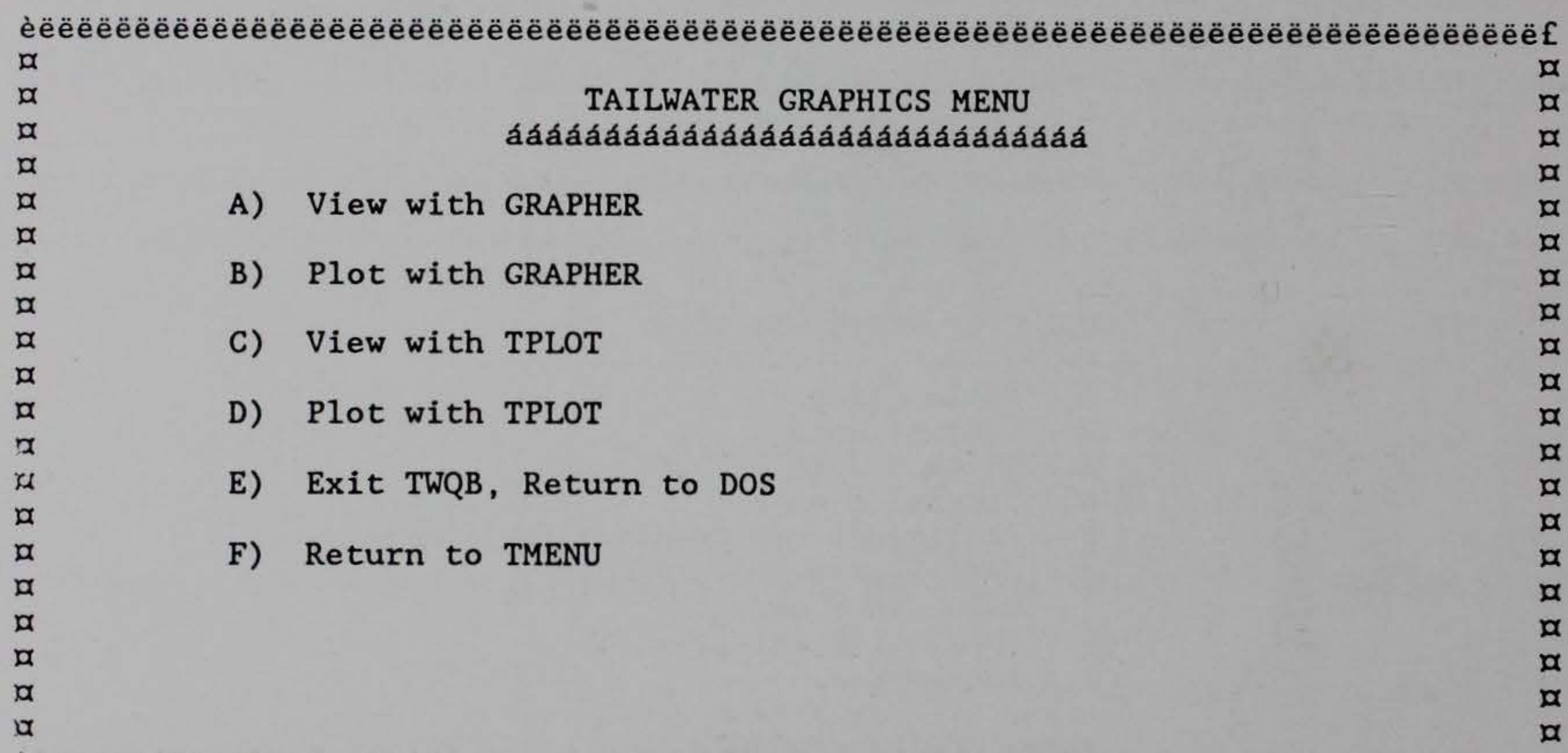
àëëëëëëëëëëëëëëëëëëëëëëëëëëëëëëëëëëëëëëëëëëëëëëëëëëëëëëëëëëëëëëëëëëëëëëëëëëëë¥

Figure B33. First graphics screen 


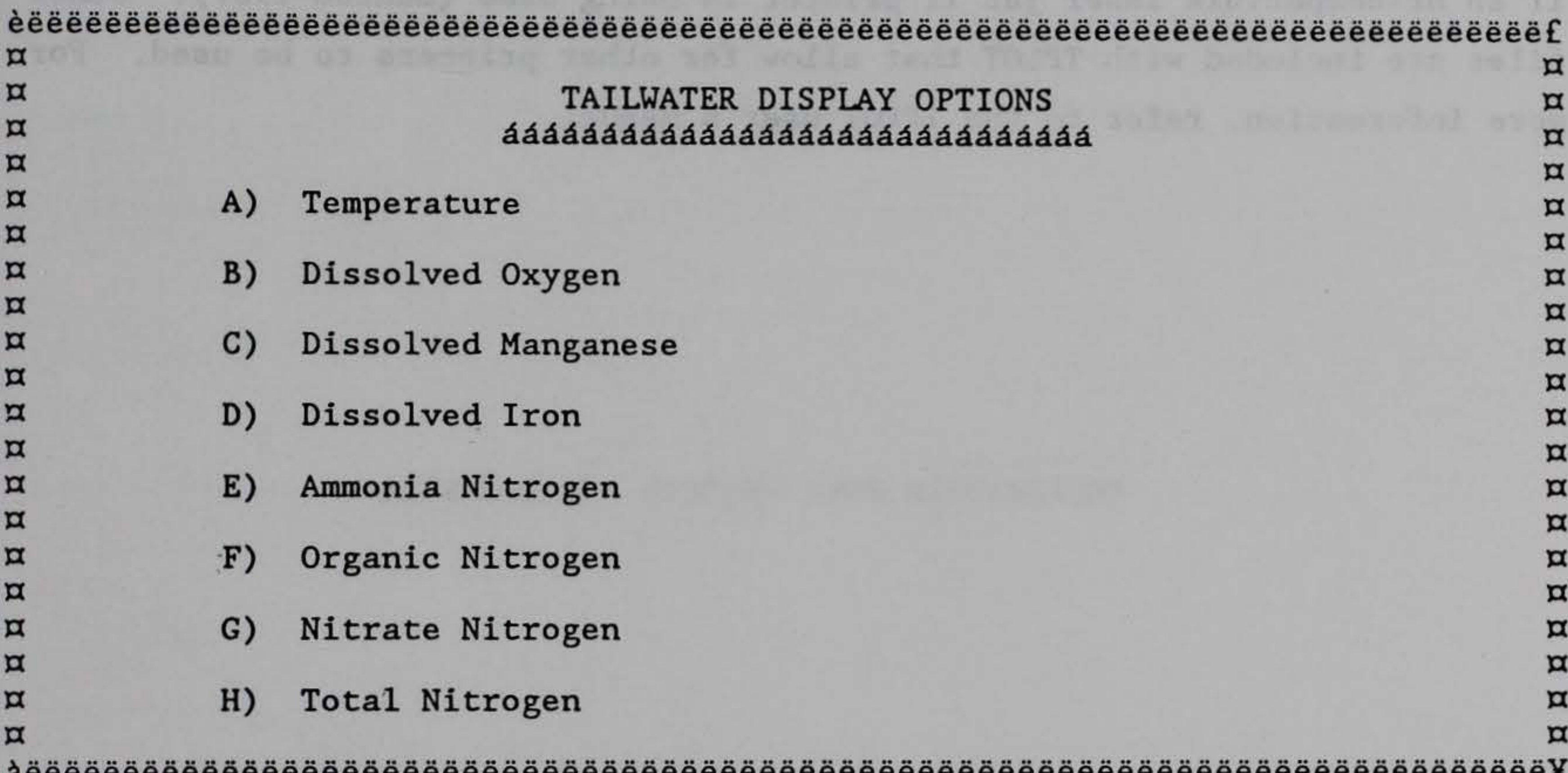

Which would you like to Graph (A, B. . . H or EXIT) ?

Figure B34. Constituent options 
56. When the constituent options menu is exited, the first graphics screen appears and another selection can be made (Figure B33). The user selects $E$ to exit from TWQM.

57. The plotting options for TPLOT may be selected even if a printer is not attached to the computer. This program creates the plotting files, which are dumped to a printer. One file is created for each graph. These files are: TPTPLOT1.OUT, TPTPLOBS.OUT, FETPLOT1.OUT, MNTPLOT1.OUT, DOTPLOT1.OUT, FETPLOBS.OUT, MNTPLOBS.OUT, and DOTPLOBS.OUT. When the plotting option for TPLOT is selected, these files are created but not sent to a printer. Once TWQB is complete, these files can be sent to a printer by typing HP2LJET fn.ft if an HP-compatible laser jet II printer is being used (Benton 1987). Other files are included with TPLOT that allow for other printers to be used. For more information, refer to the TPLOT user's manual. 
APPENDIX C: KINETIC RATE REGRESSIONS

C1 


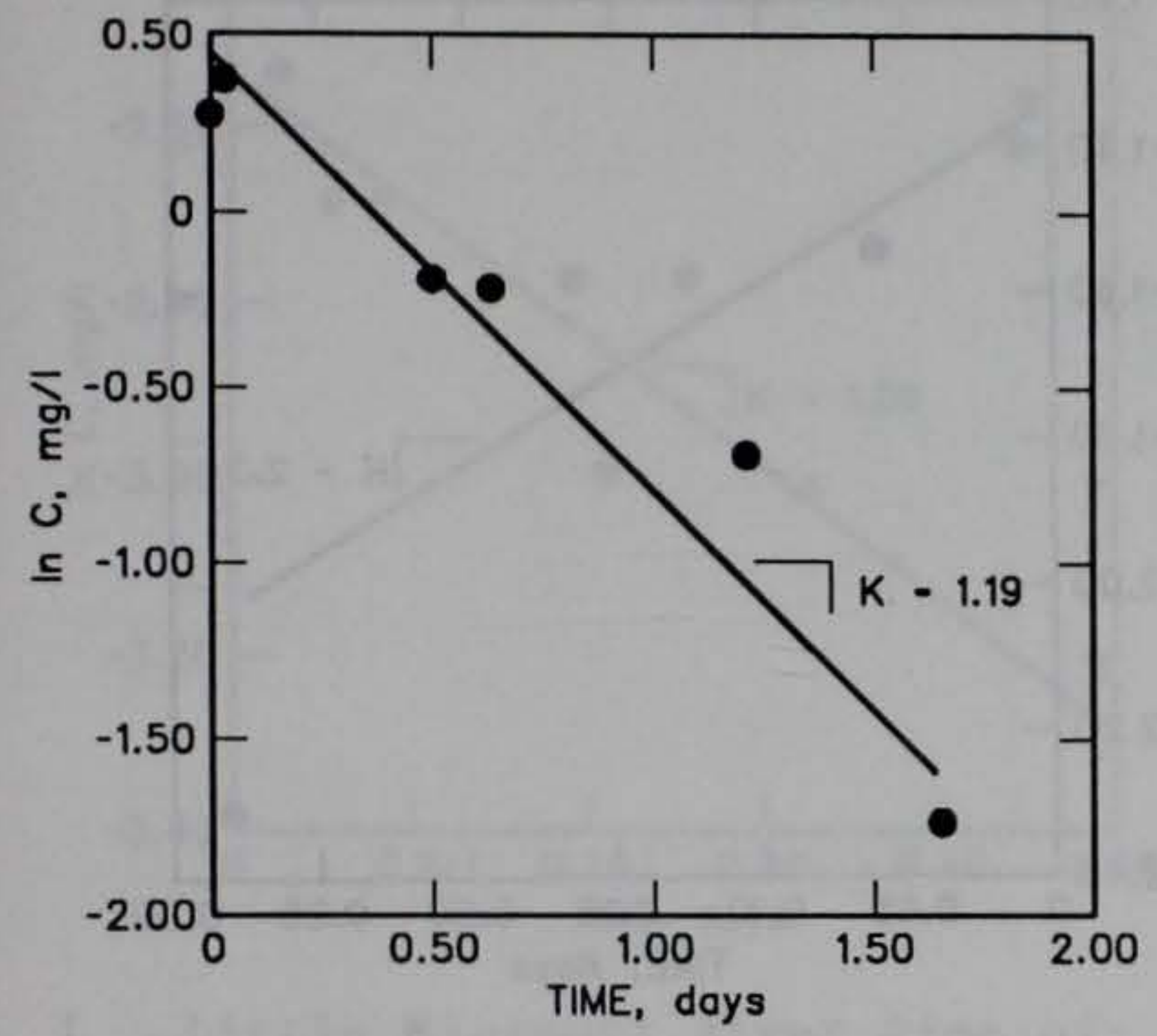

a. Duck River (data set 1 ), 43 cfs

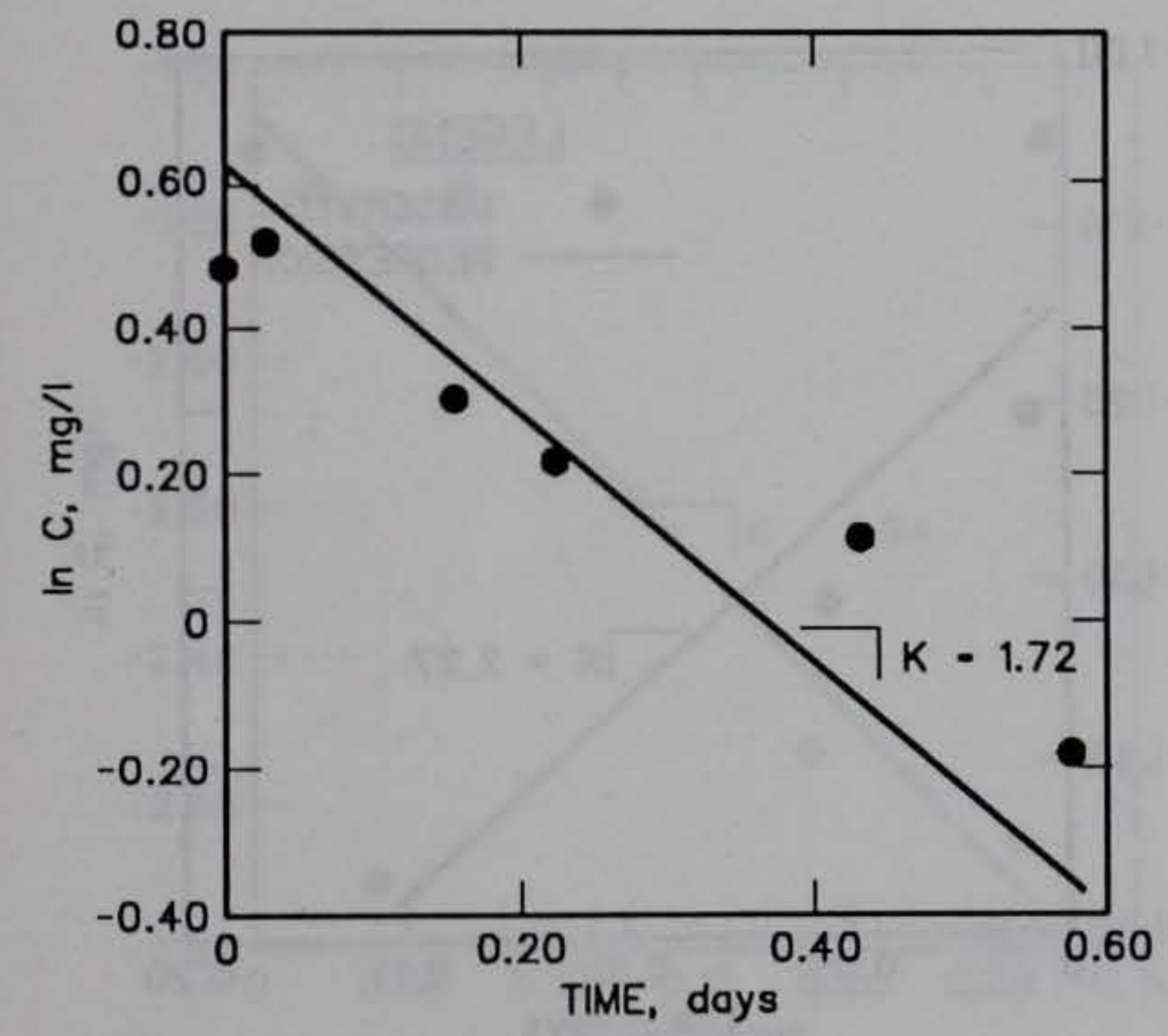

c. Duck River (data set 3 ), 182 cfs

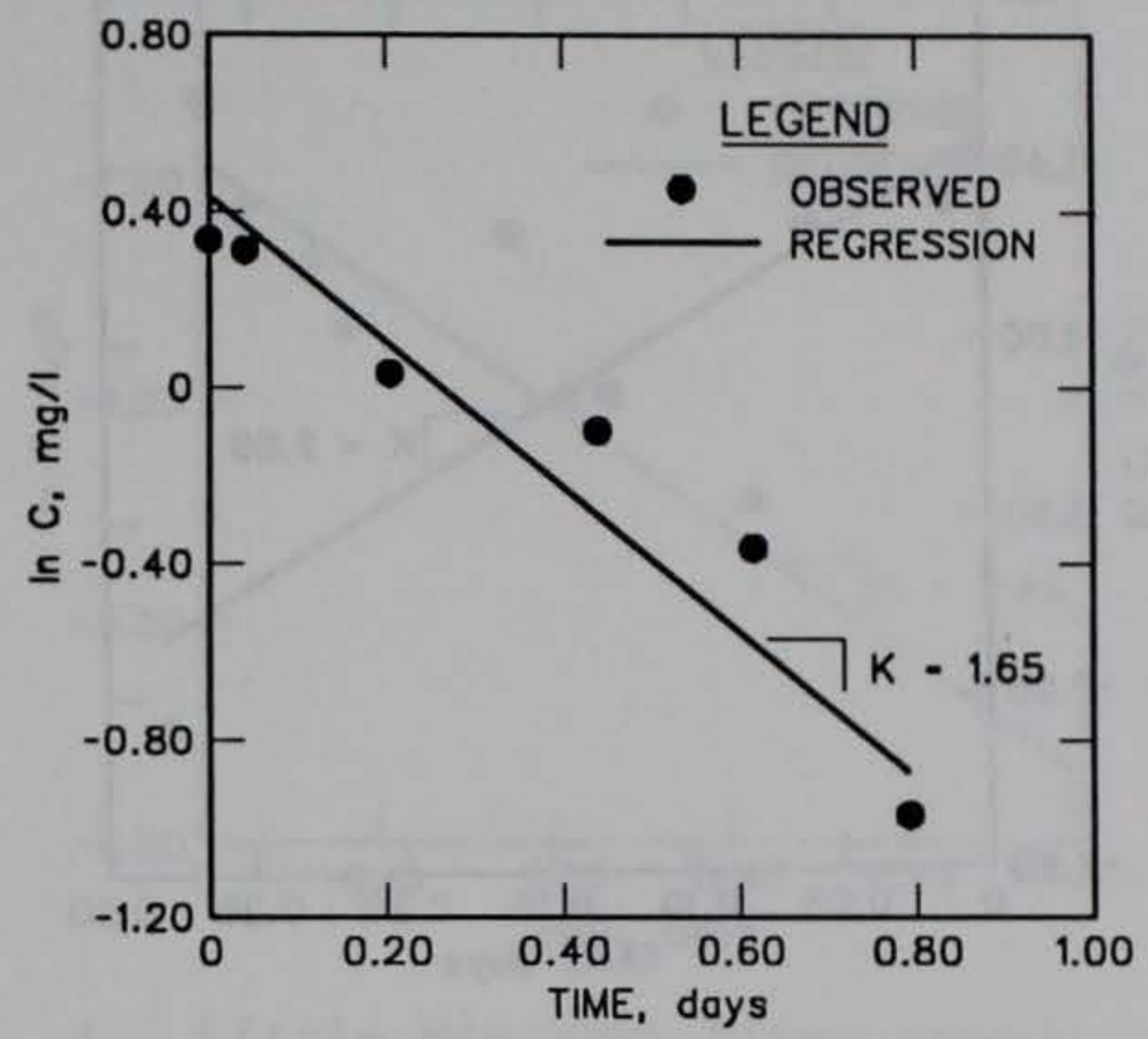

b. Duck River (data set 2), 119 cfs

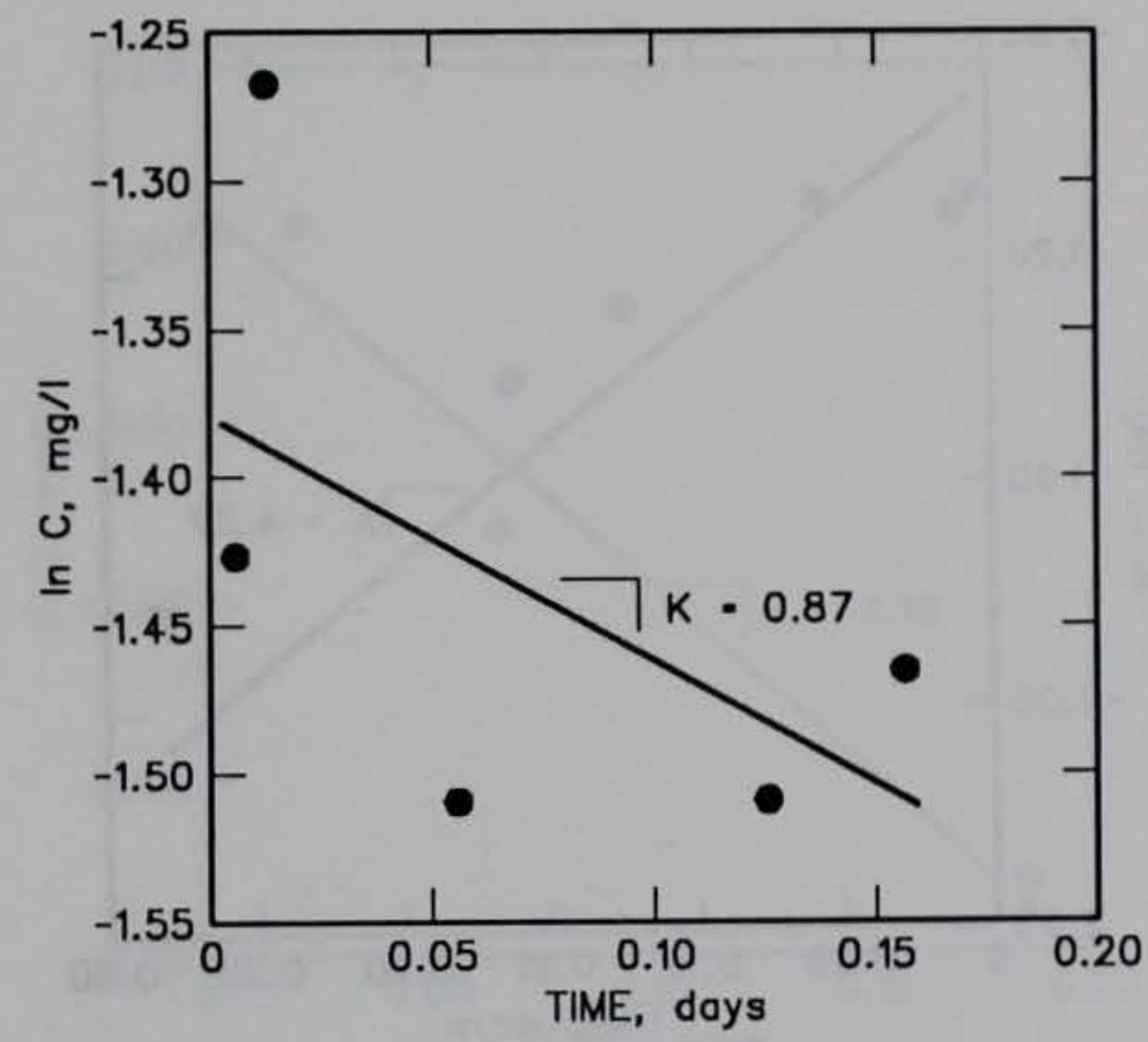

d. Little Missouri River (data set 1), $25 \mathrm{Ju} 1983$

Figure C1. Regressions for dissolved manganese removal rate (Sheet 1 of 6) 


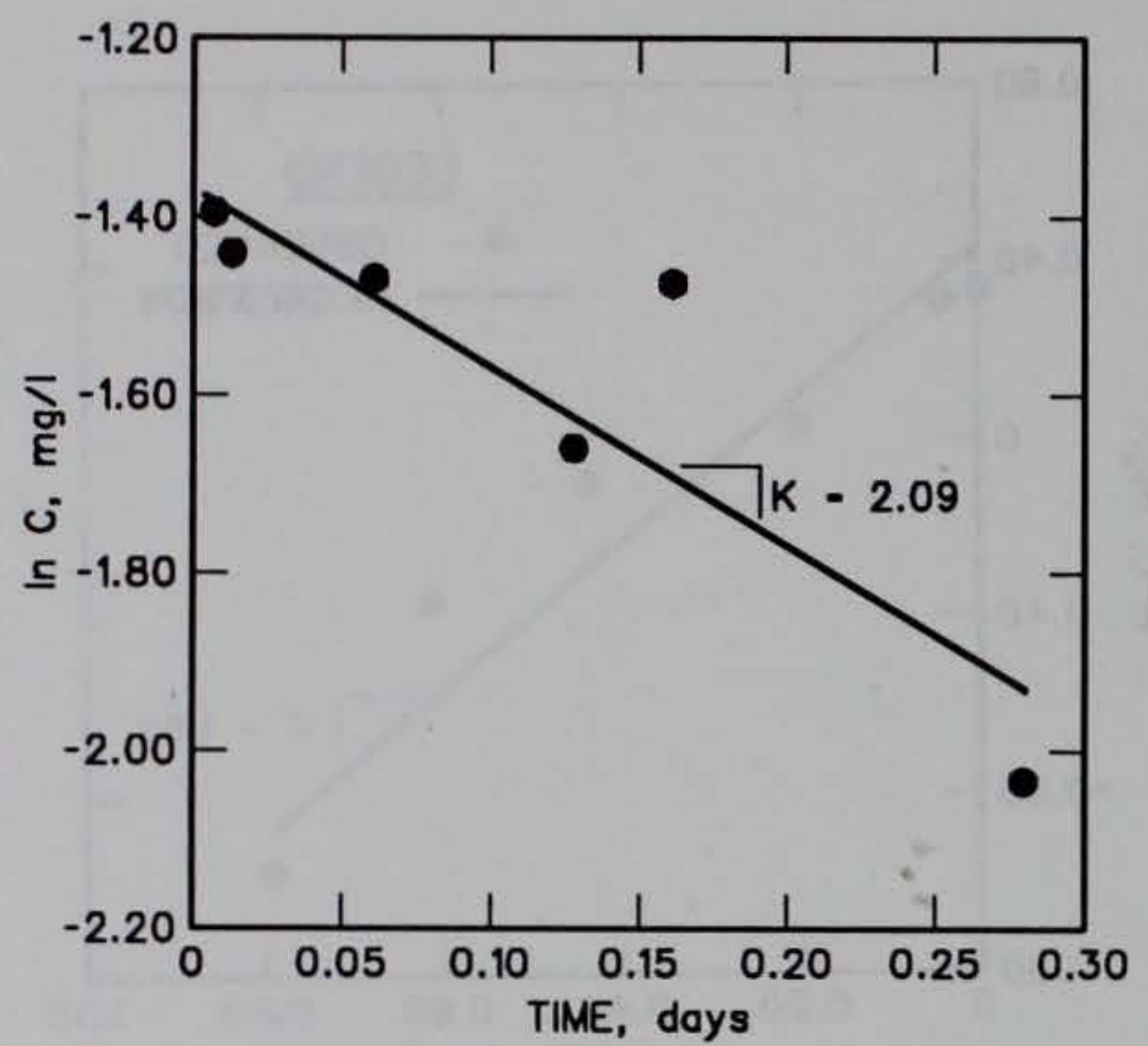

e. Little Missouri River

(data set 2), 9 Aug 1983

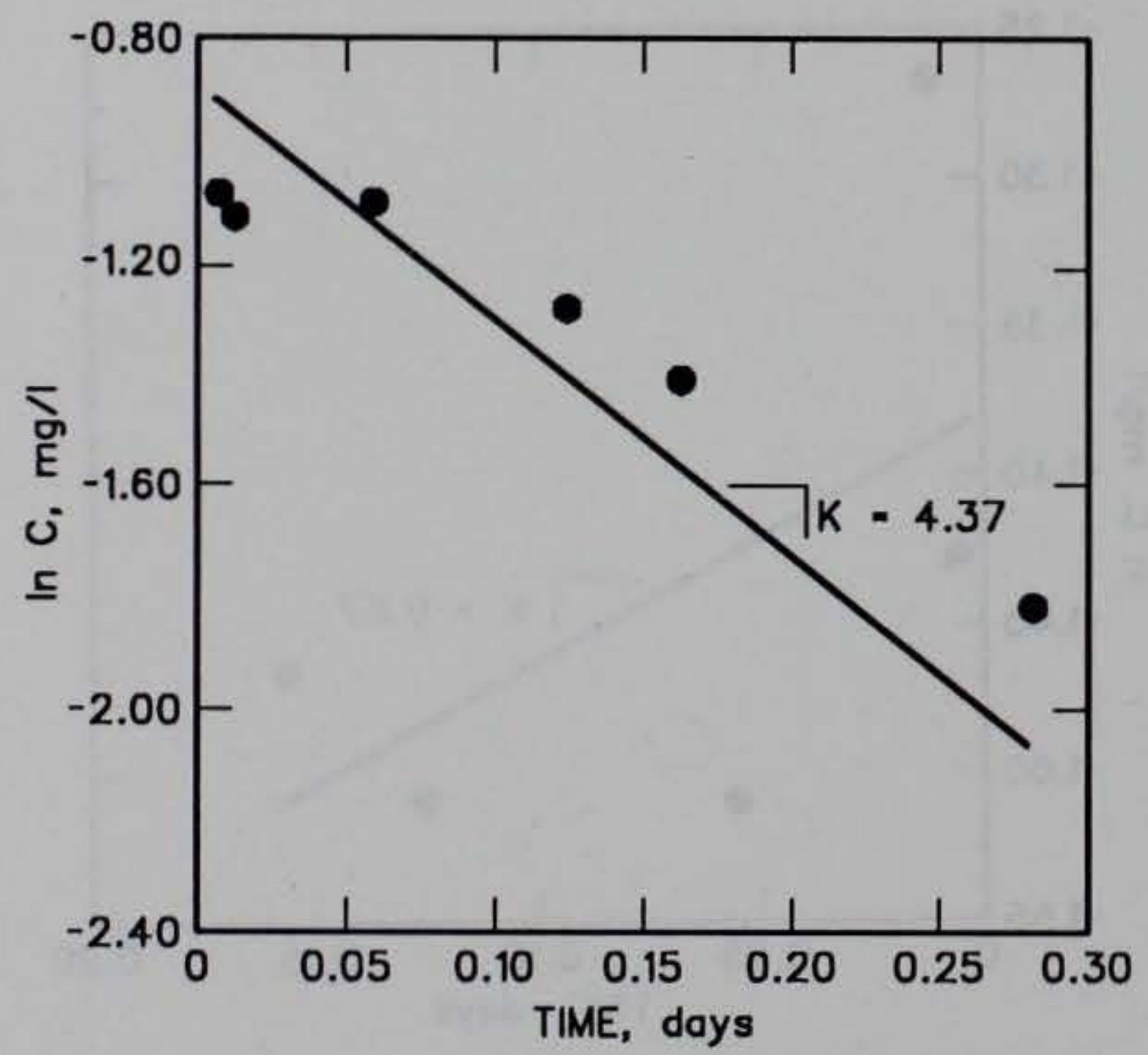

g. Little Missouri River

(data set 4), 7 Sep 1983

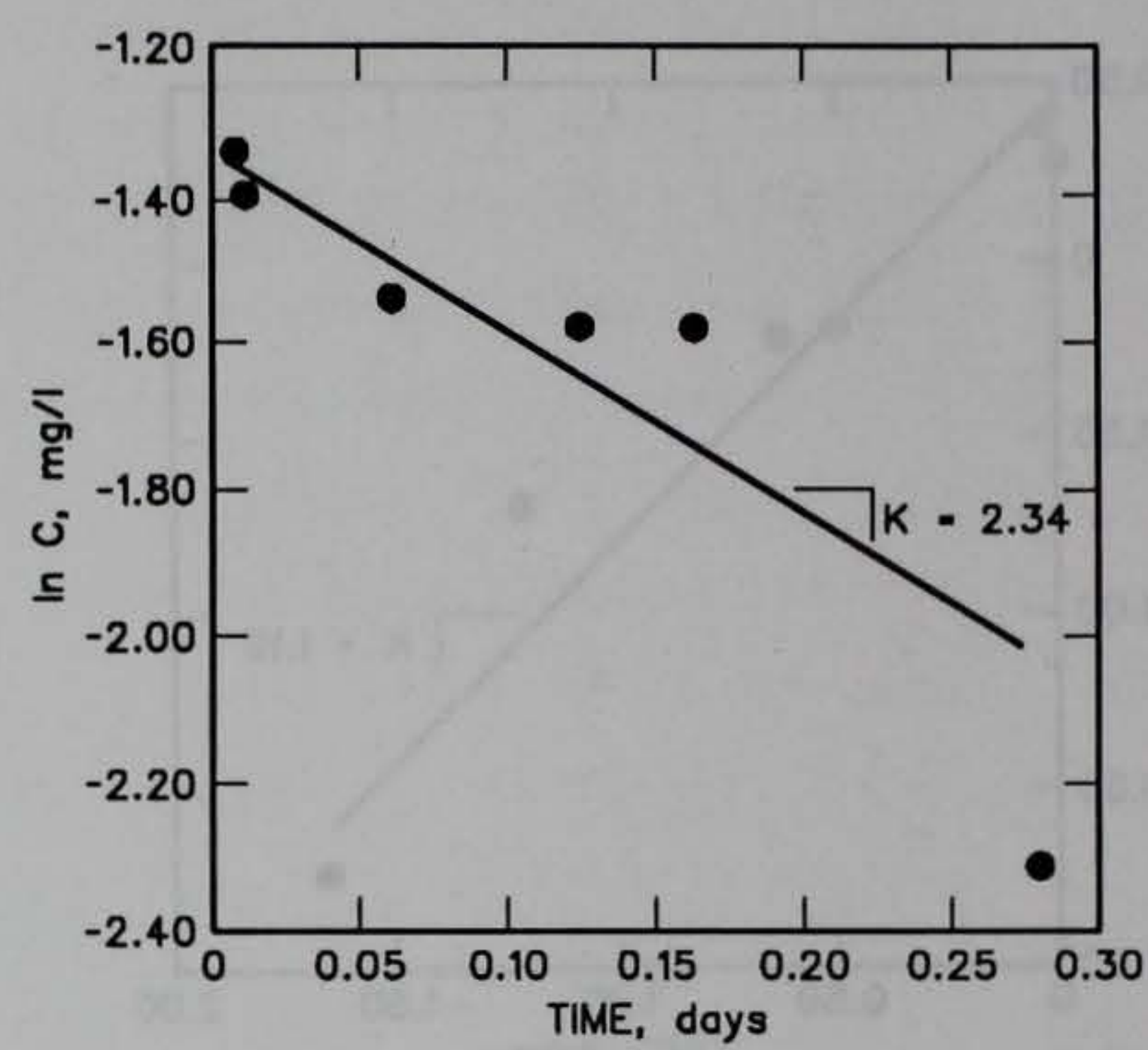

f. Little Missouri River (data set 3)

17 Aug 1983

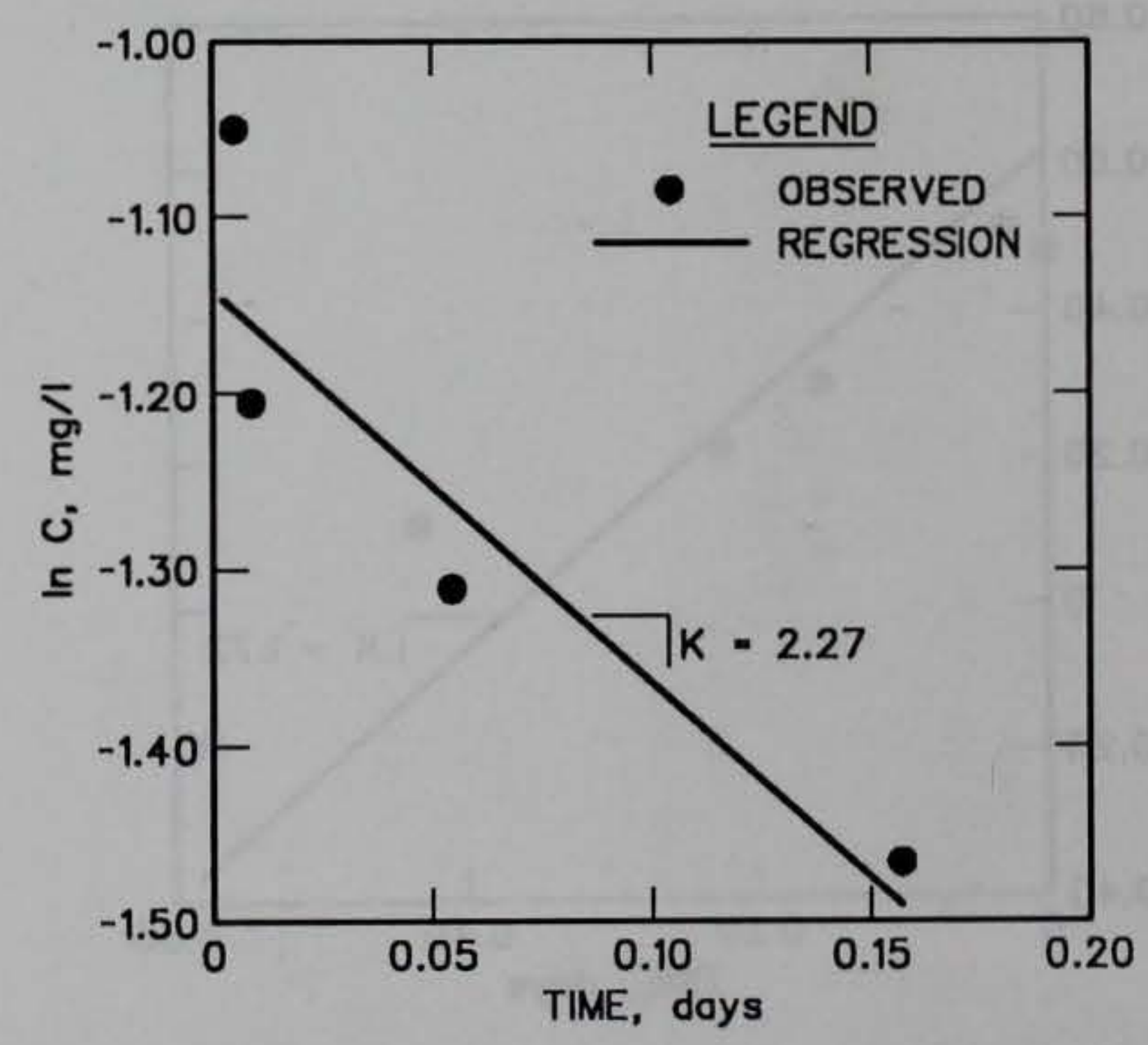

h. Little Missouri River (data set 5) 27 Oct 1983

Figure C1. (Sheet 2 of 6 ) 


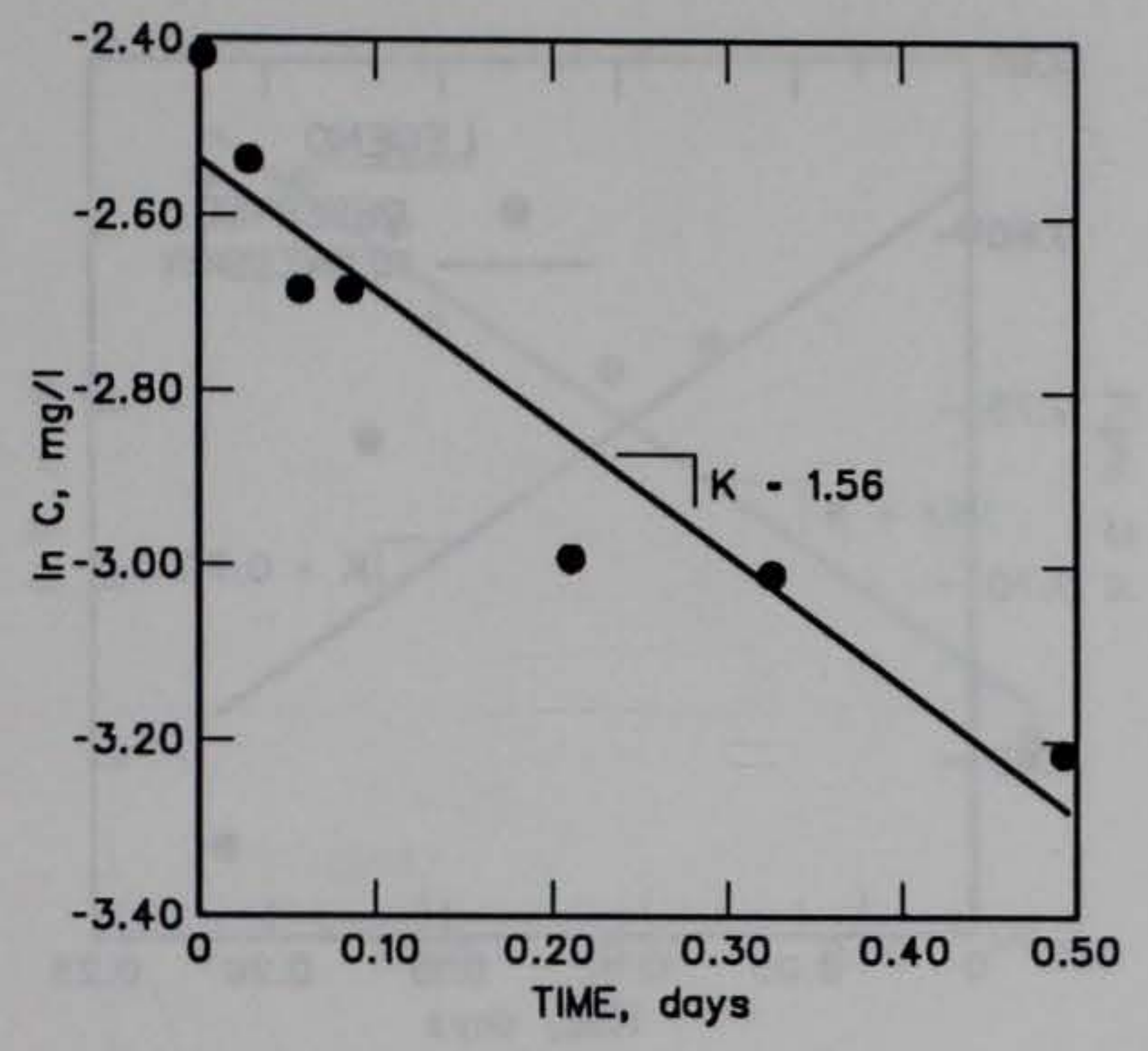

i. Little Missouri River time-oftravel sampling at 500 cfs (data set 6), 12 Sep 1987

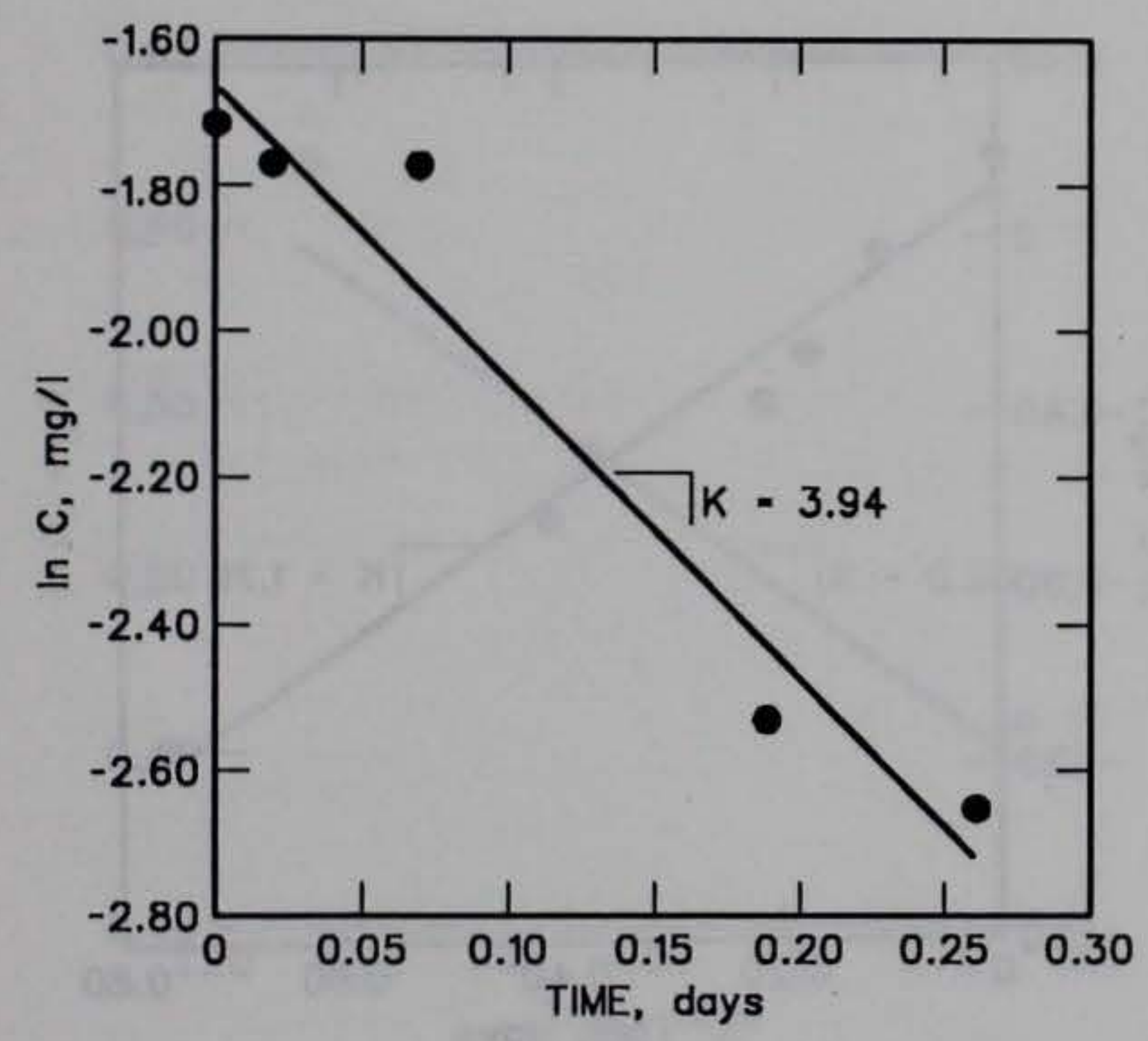

k. Little Missouri River time-oftravel sampling at $500 \mathrm{cfs}$ (data set 8$), 14$ Oct 1987

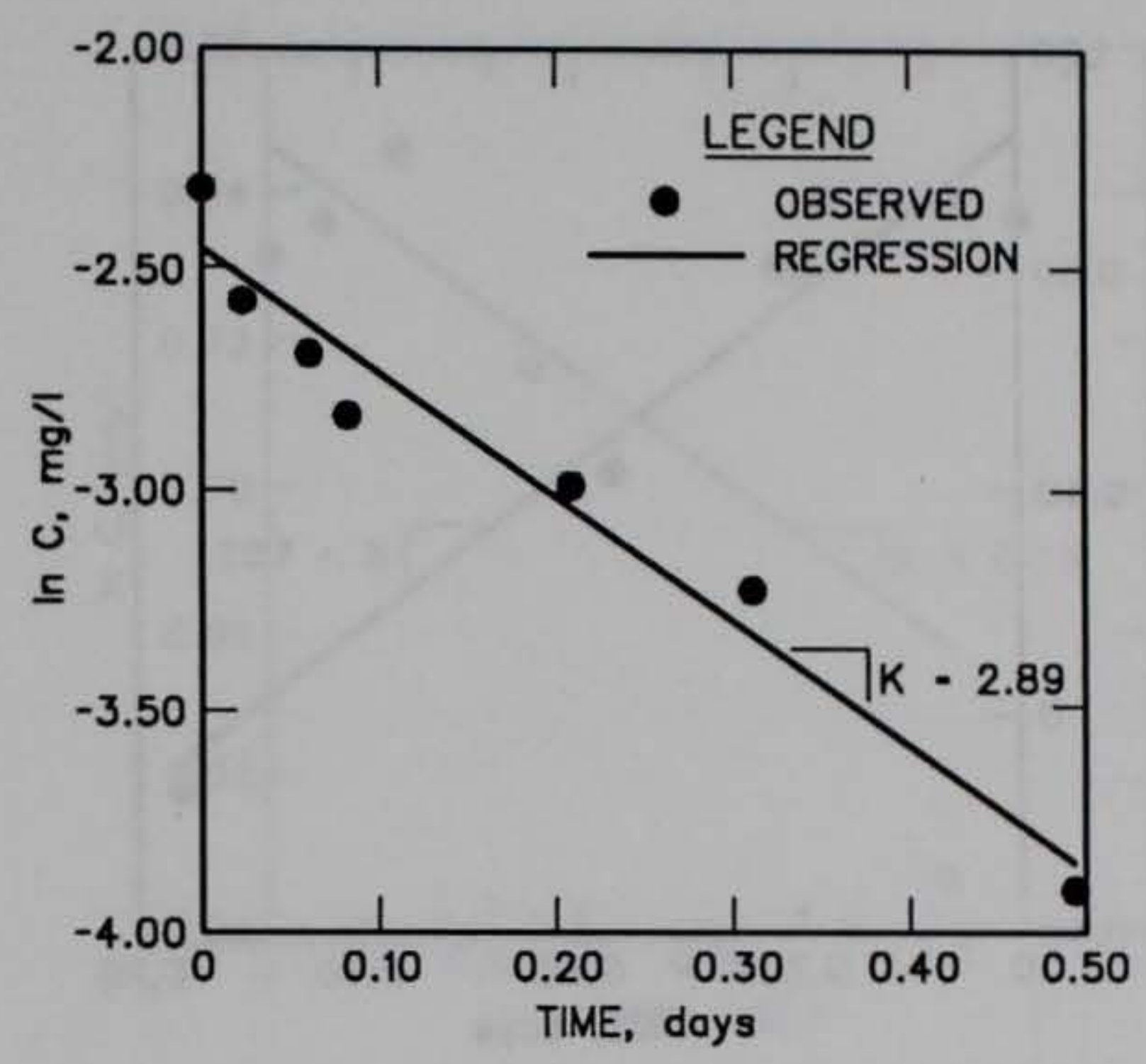

j. Little Missouri River steadystate sampling at $500 \mathrm{cfs}$ (data set 7), 12 Sep 1987

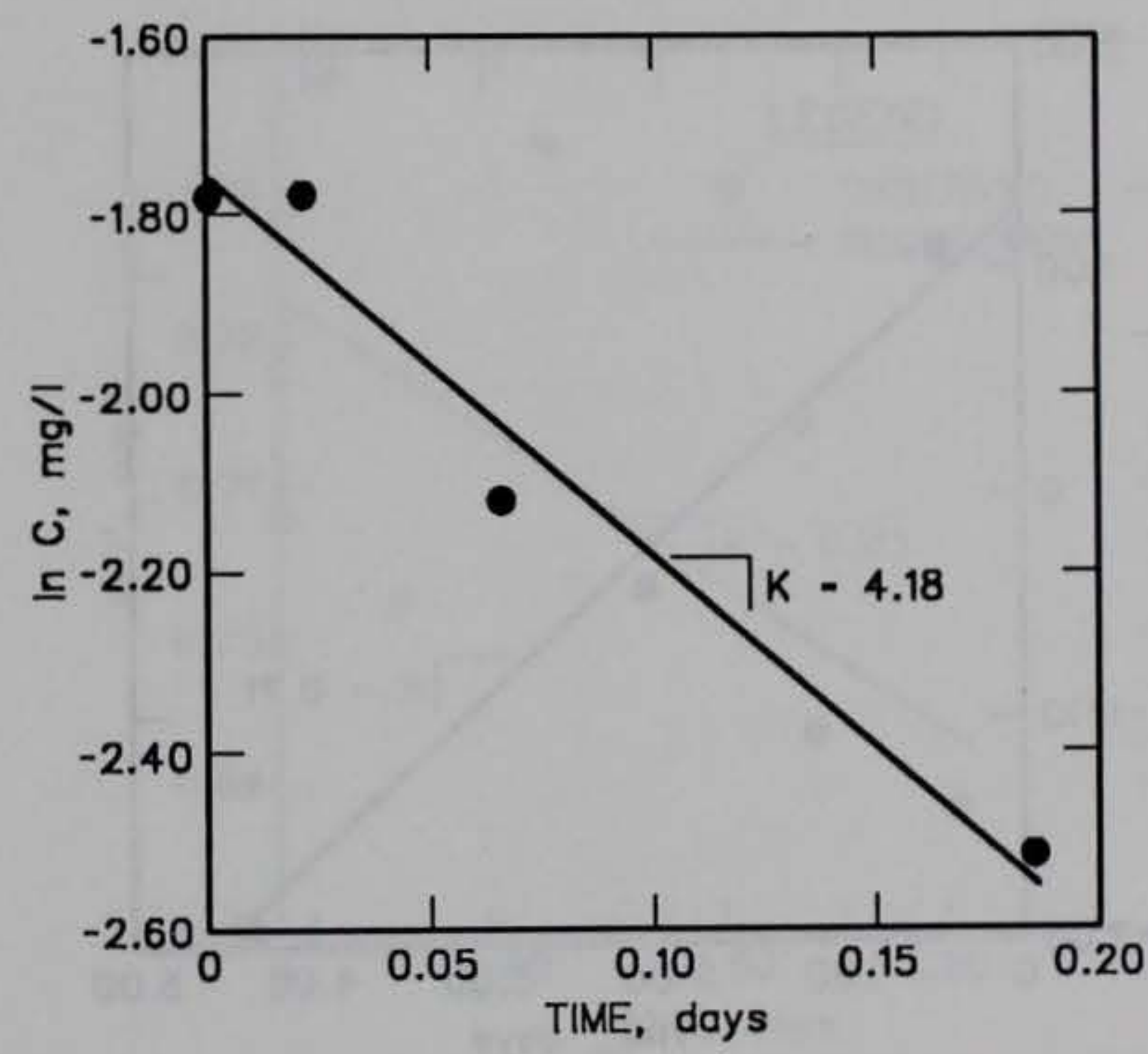

1. Little Missouri River steadystate sampling at $500 \mathrm{cfs}$ (data set 9), 14 Oct 1987

Figure C1. (Sheet 3 of 6 ) 


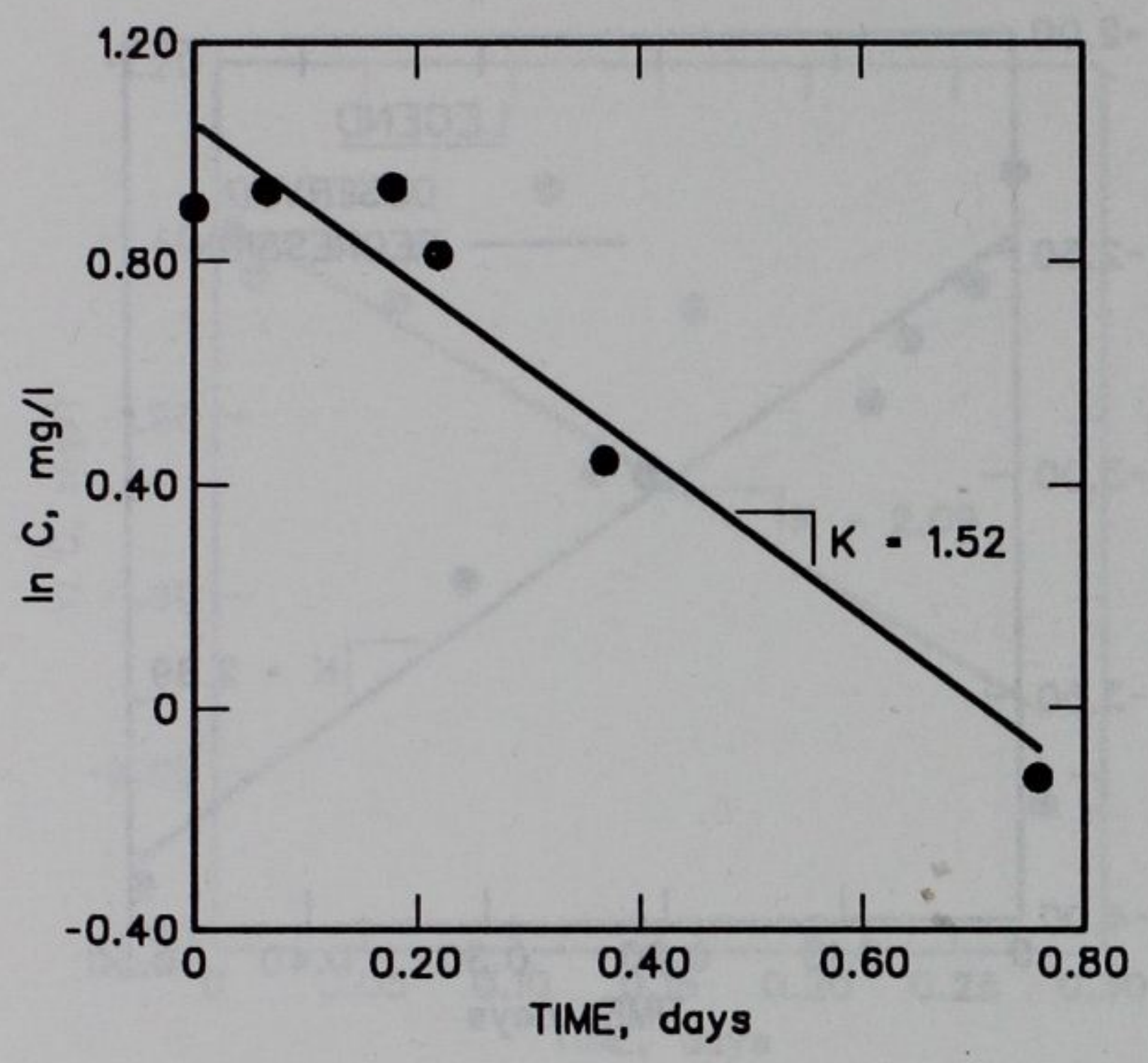

m. Fourche La Fave River steadystate sampling at $200 \mathrm{cfs}$ data set 1), $20 \mathrm{Jul} 1988$

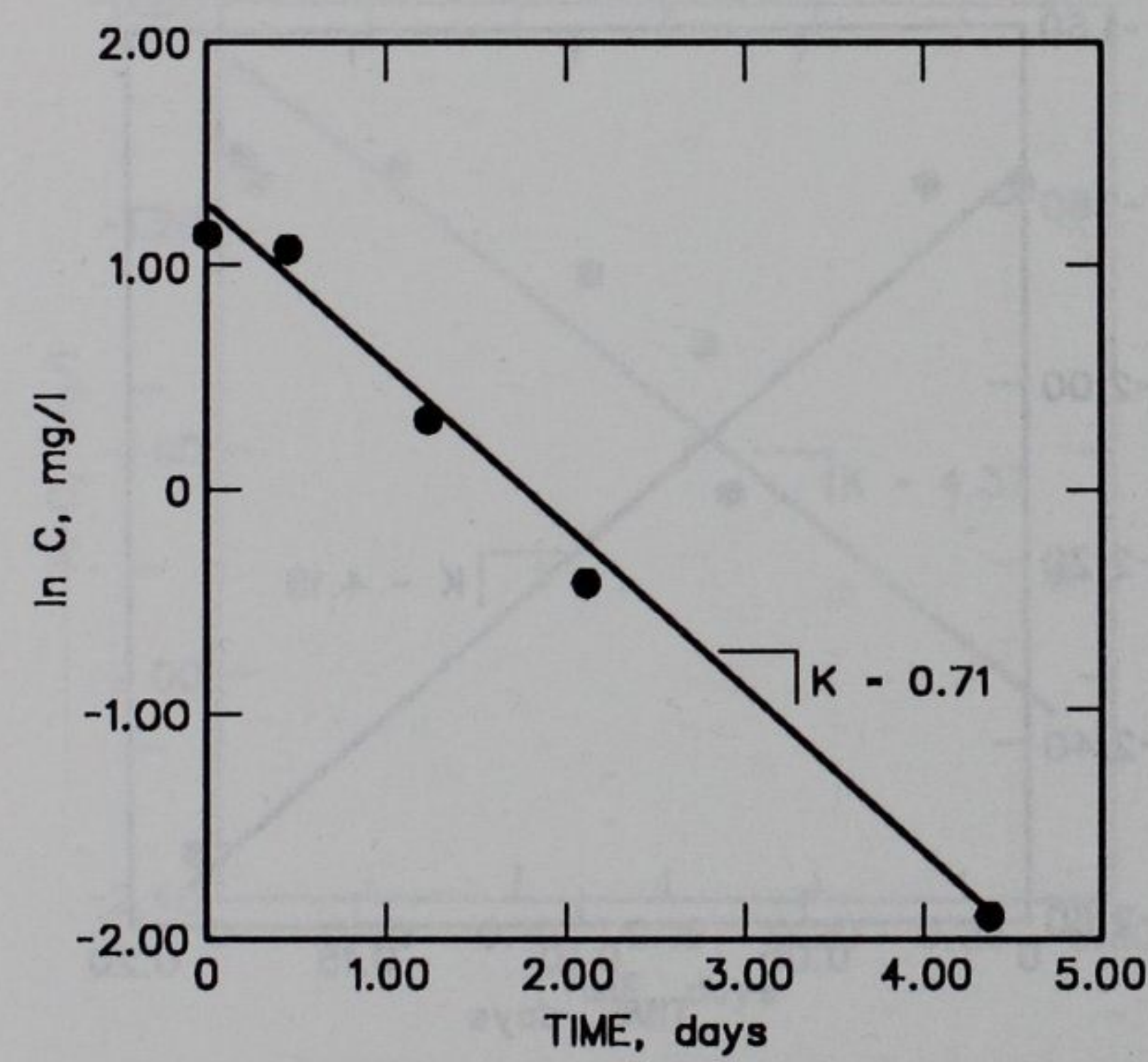

o. Fourche La Fave River low-flow steady-state sampling at $25 \mathrm{cfs}$ (data set 3 ), $19 \mathrm{Jul} 1988$

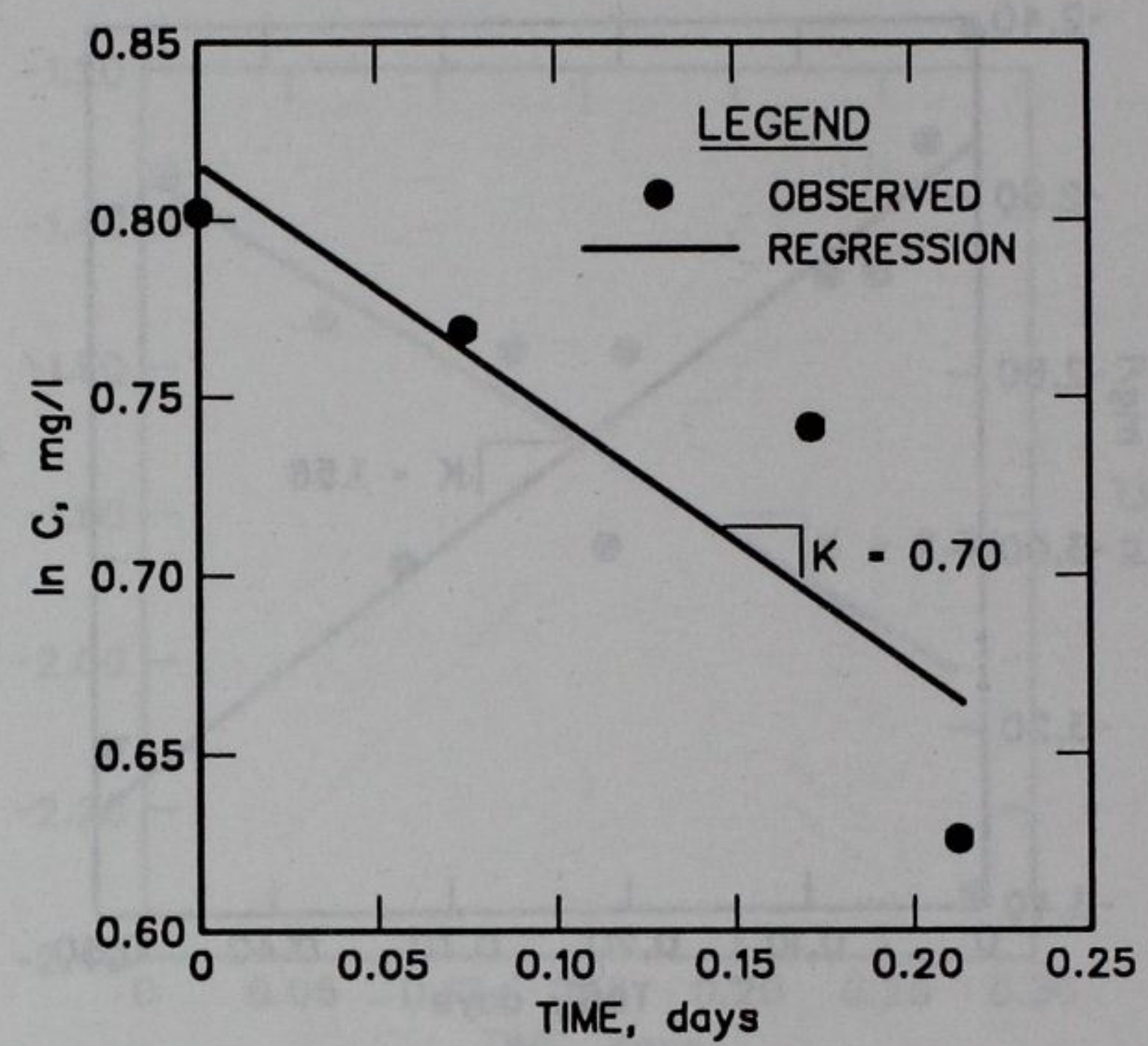

n. Fourche La Fave River time-oftravel sampling at $200 \mathrm{cfs}$ (data set 2), $20 \mathrm{Jul} 1988$

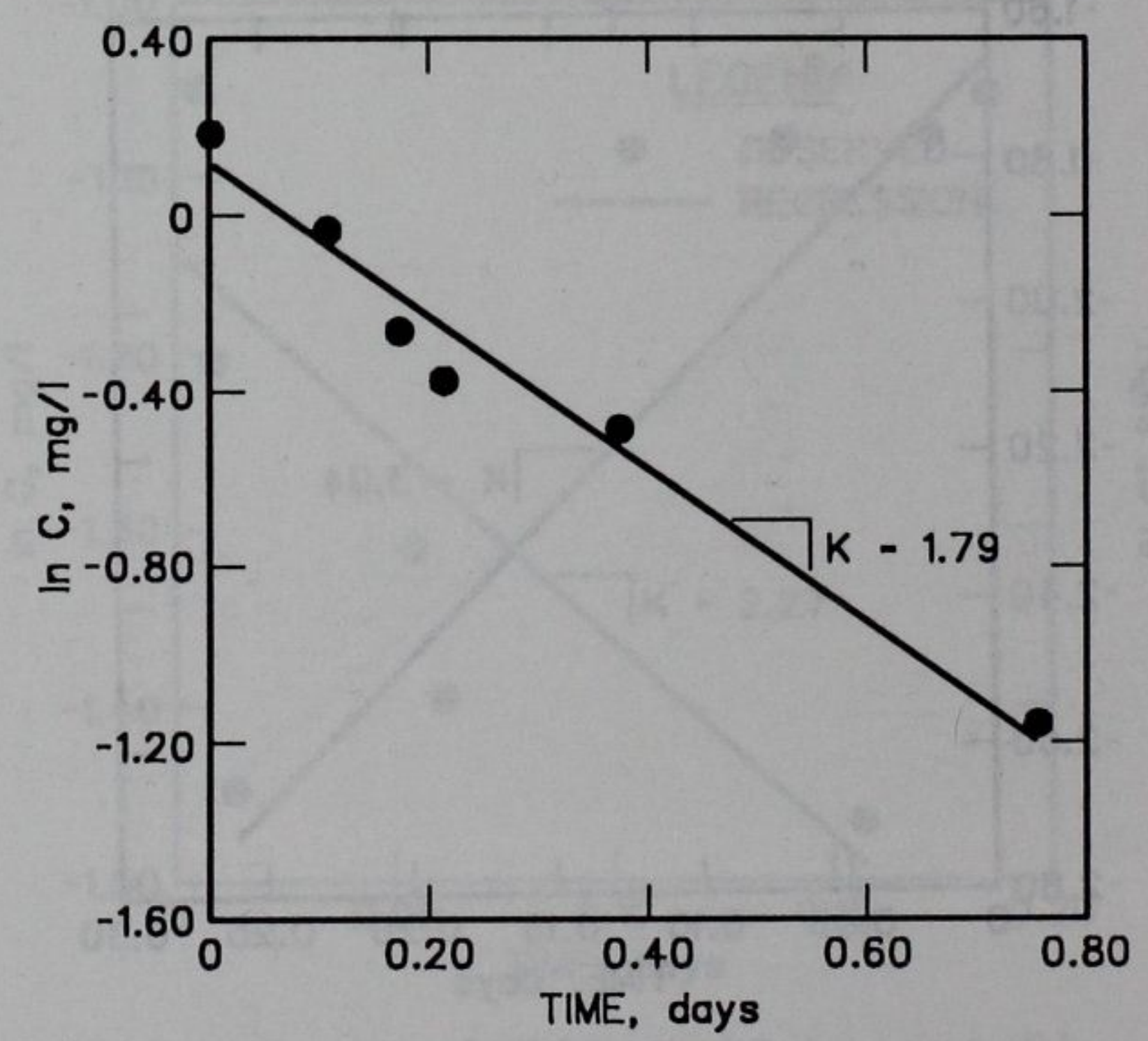

p. Fourche La Fave River steadystate sampling at $200 \mathrm{cfs}$ (data set 4), 23 Aug 1989

Figure C1. (Sheet 4 of 6 ) 


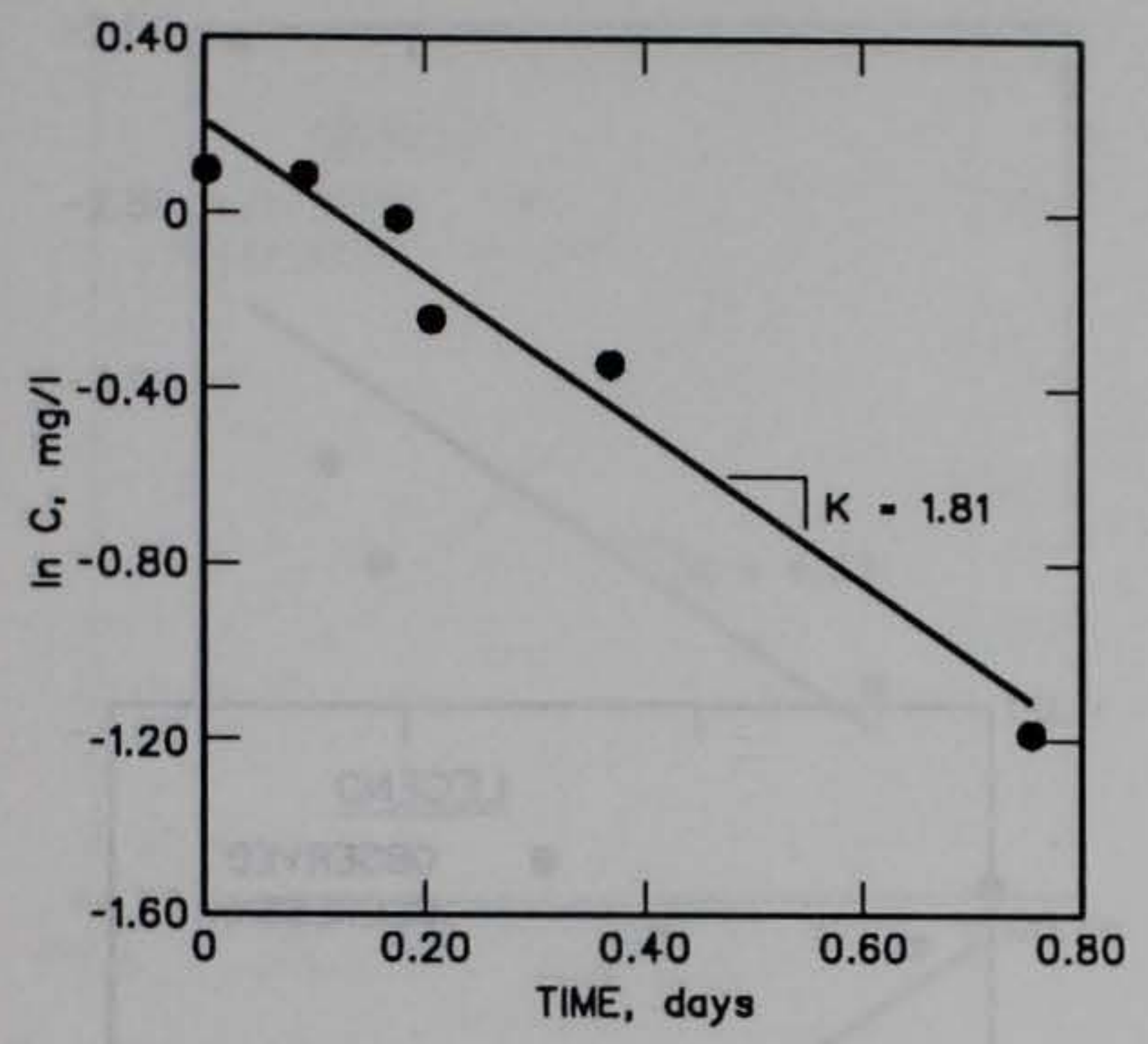

q. Fourche La Fave River steadystate sampling at $200 \mathrm{cfs}$ (data set 5), 24 Aug 1989

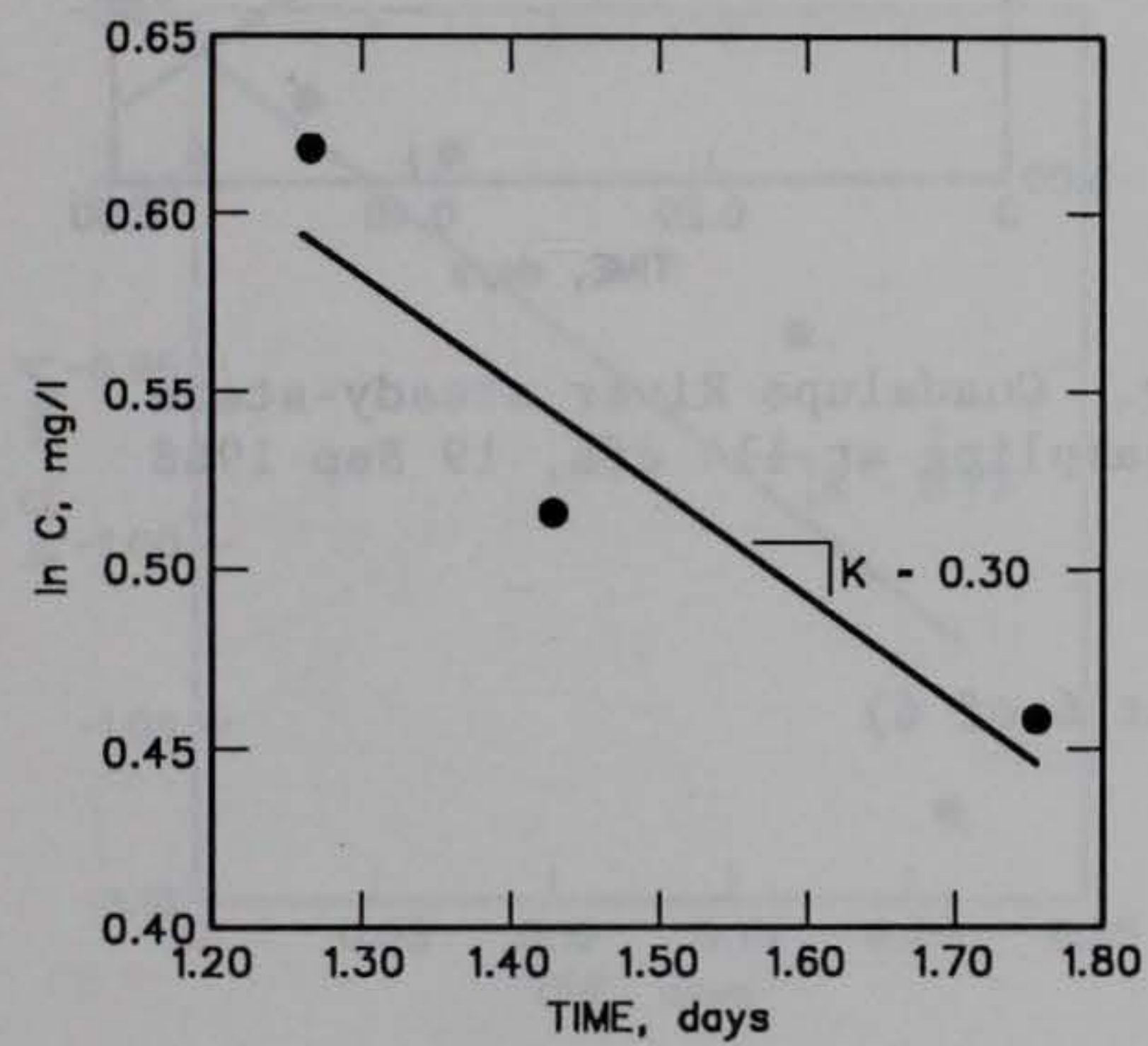

s. Rough River lower reach timeof-travel sampling at $200 \mathrm{cfs}$ (data set 2), 19 Aug 1988

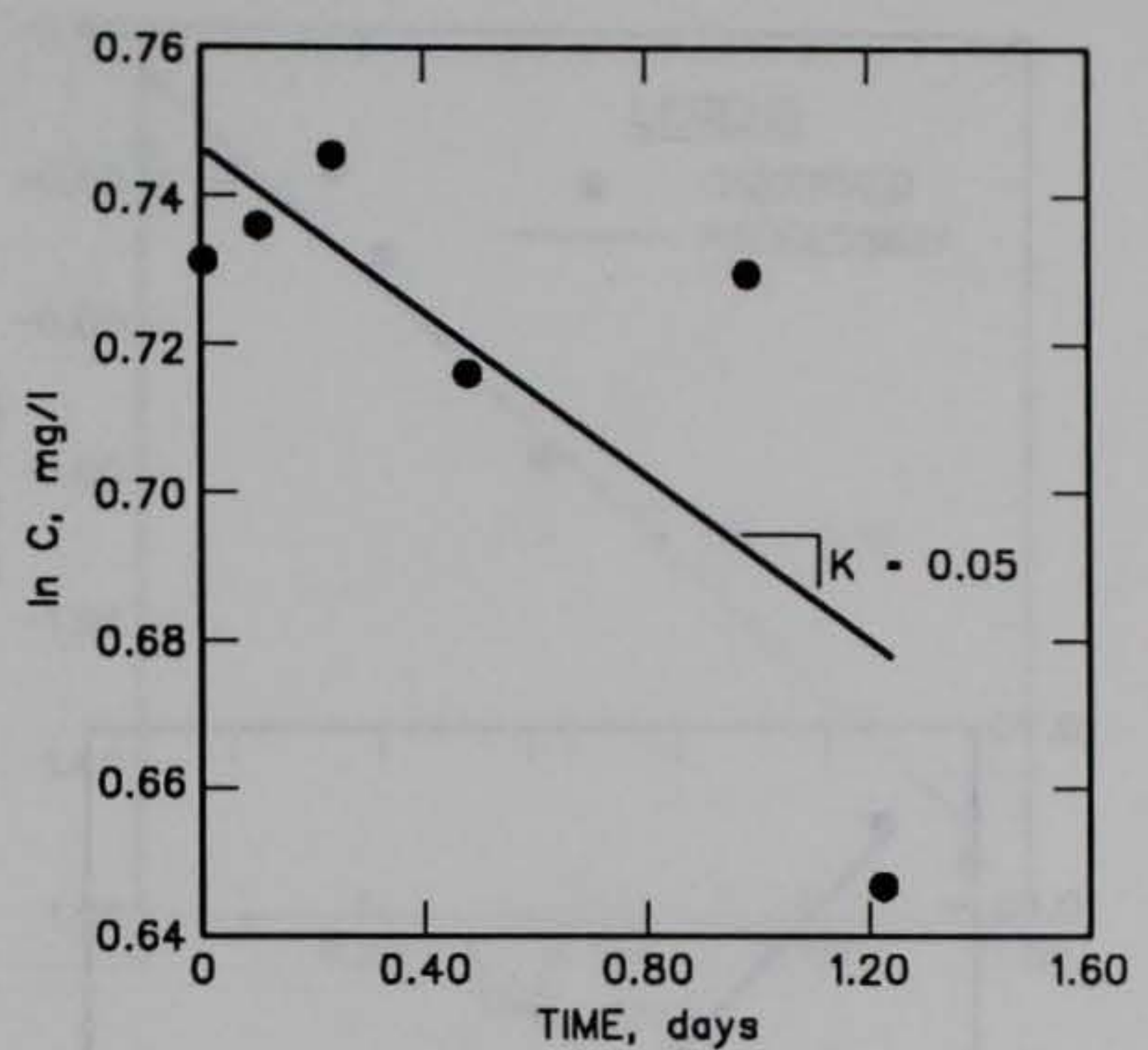

r. Rough River upper reach time-oftravel sampling at $200 \mathrm{cfs}$ (data set 1), 17 Aug 1988

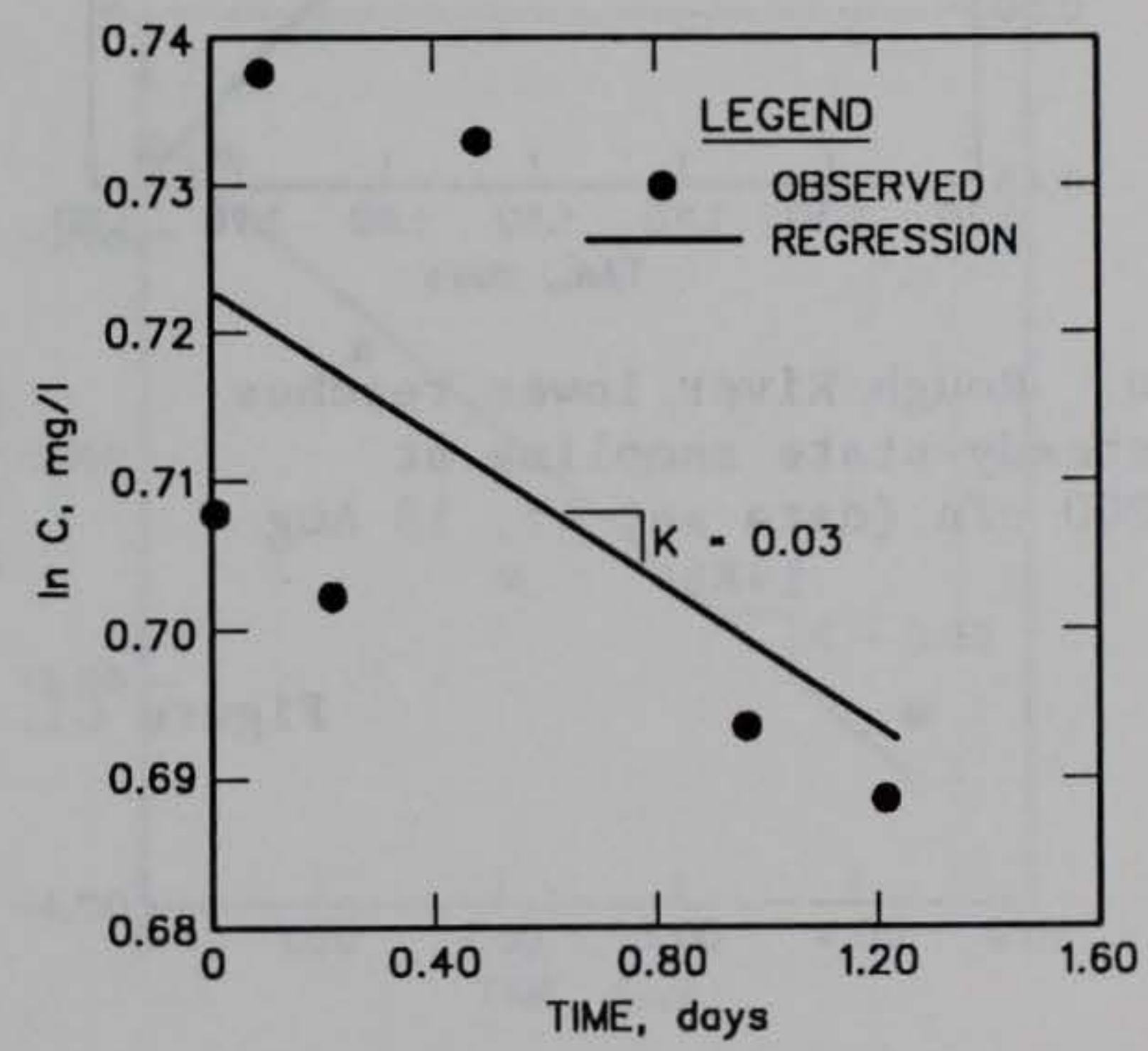

t. Rough River upper reaches steady-state sampling at $200 \mathrm{cfs}$

(data set 3), 18 Aug 1988

Figure C1. (Sheet 5 of 6 ) 


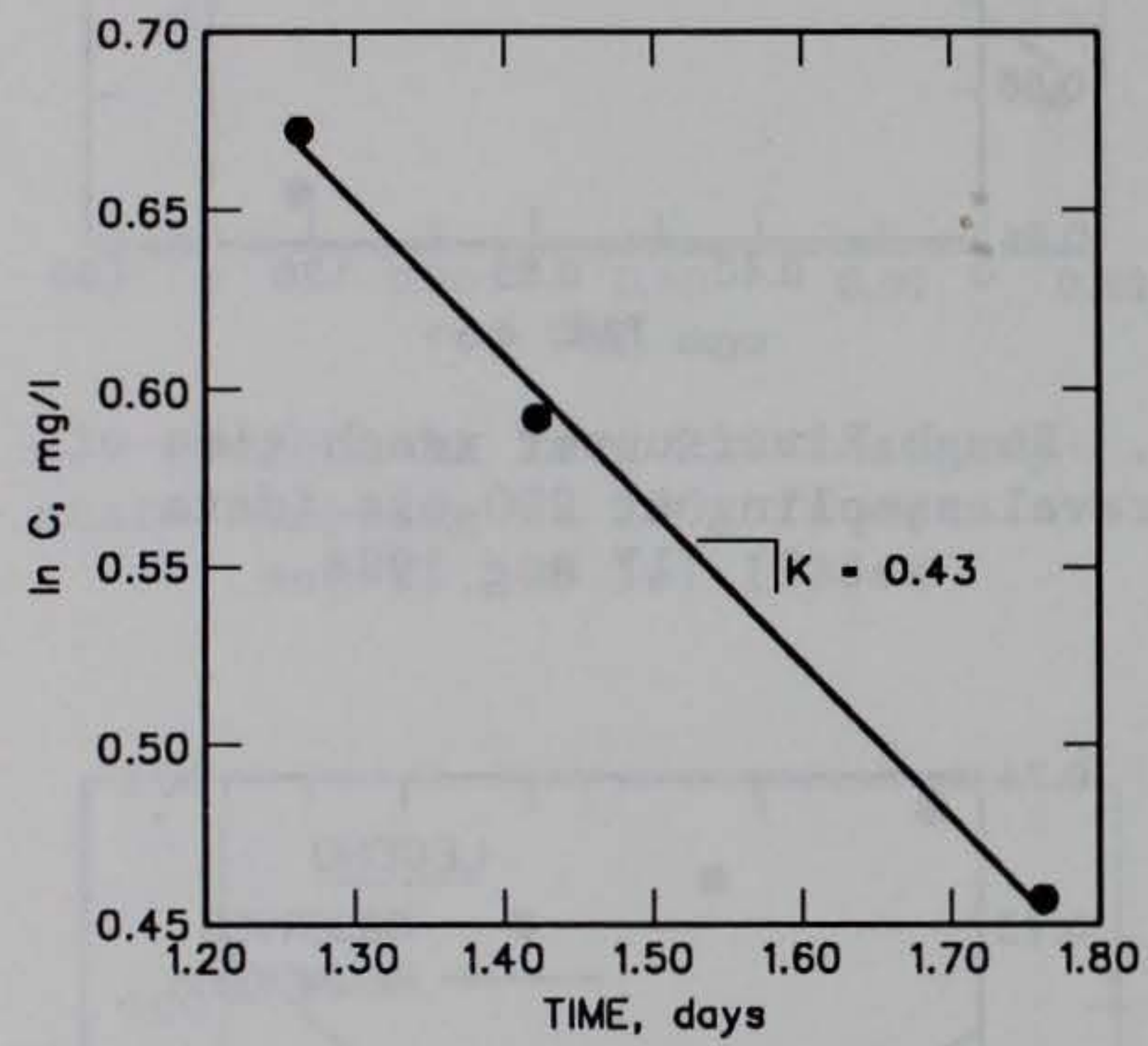

u. Rough River lower reaches steady-state sampling at 200 cfs (data set 4), 18 Aug 1988

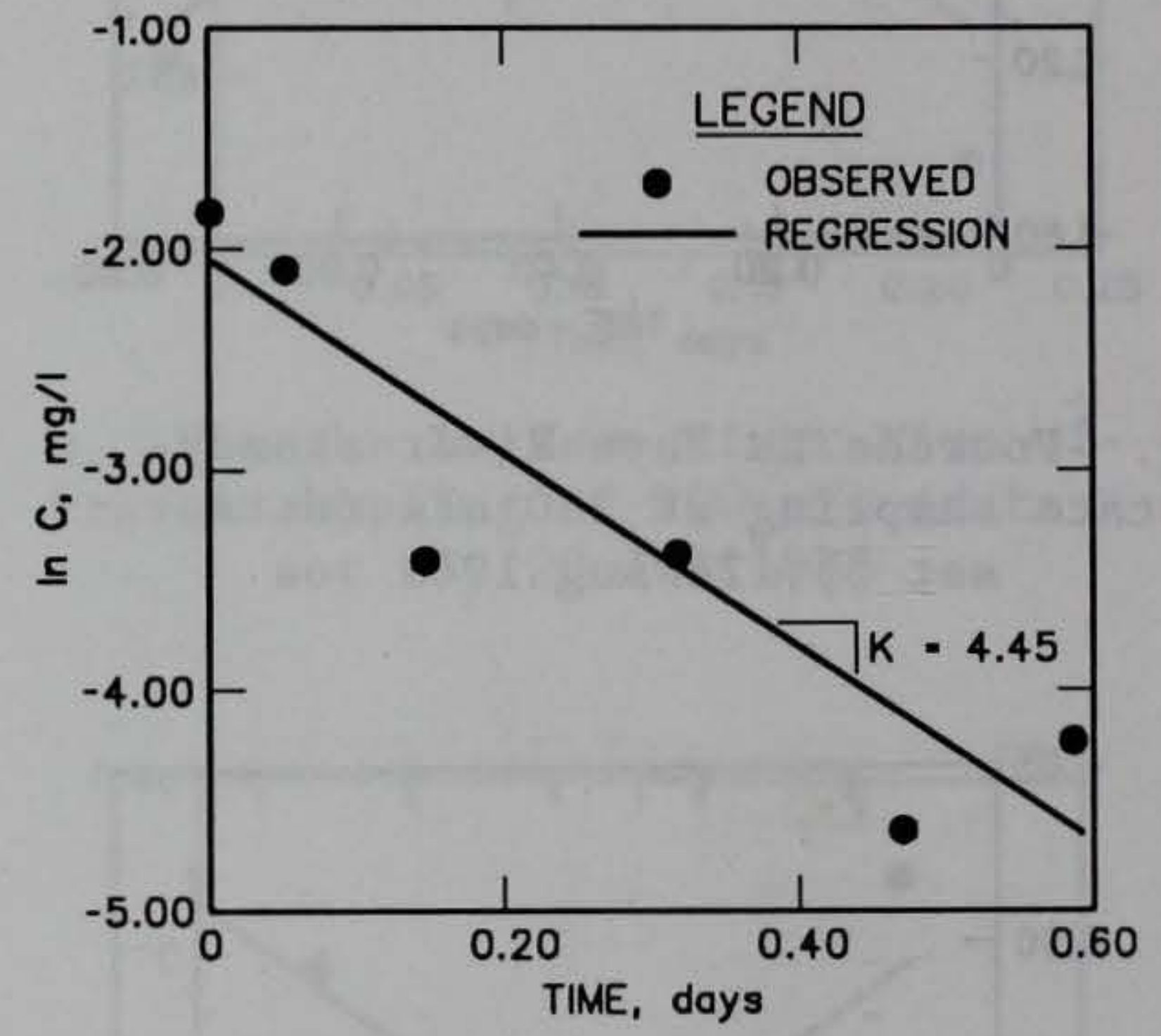

v. Guadalupe River steady-state sampling at $114 \mathrm{cfs}, 19$ Sep 1988

Figure C1. (Sheet 6 of 6 ) 


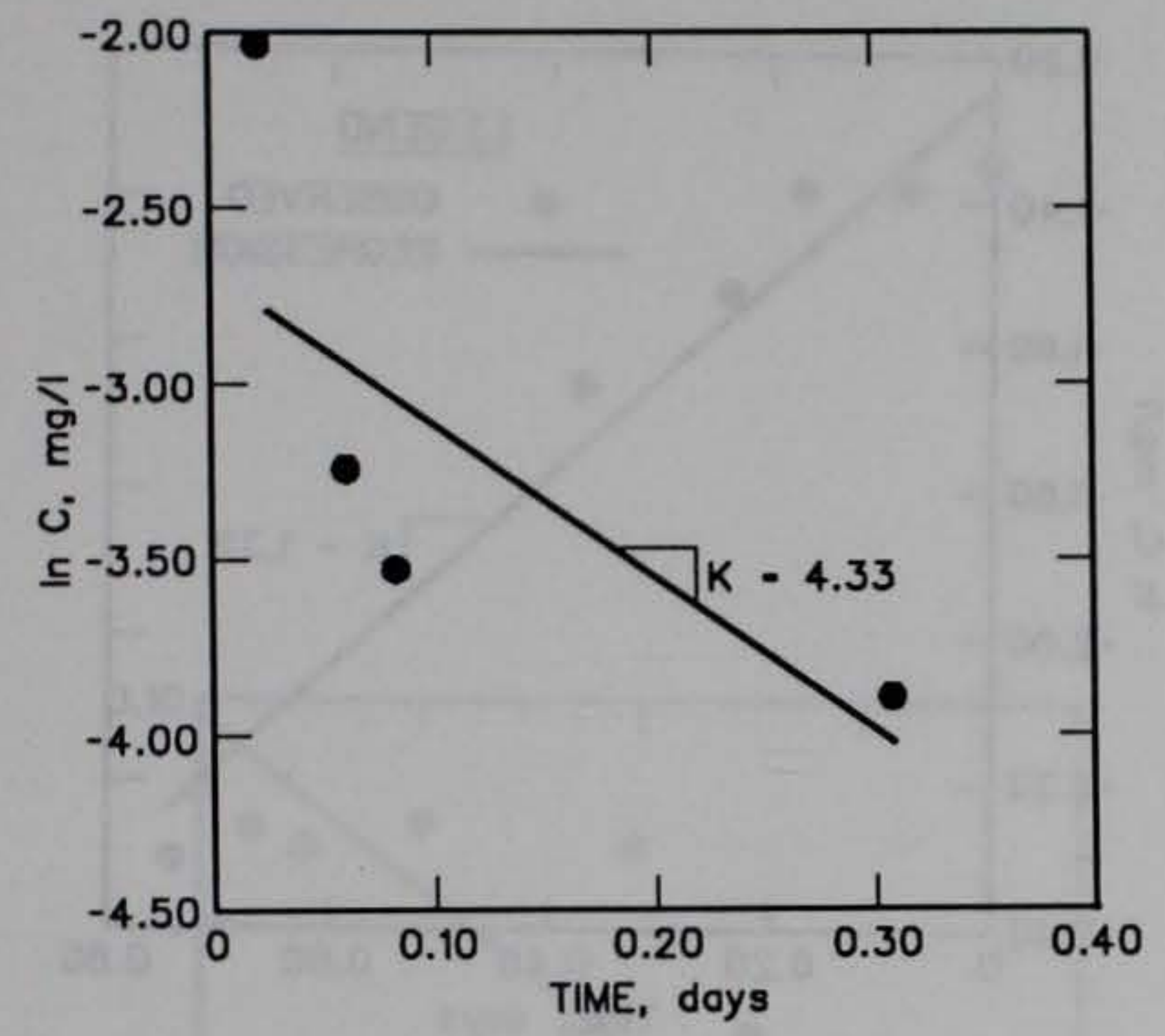

a. Little Missouri River timeof-travel sampling at $500 \mathrm{cfs}$

12 Sep 1987

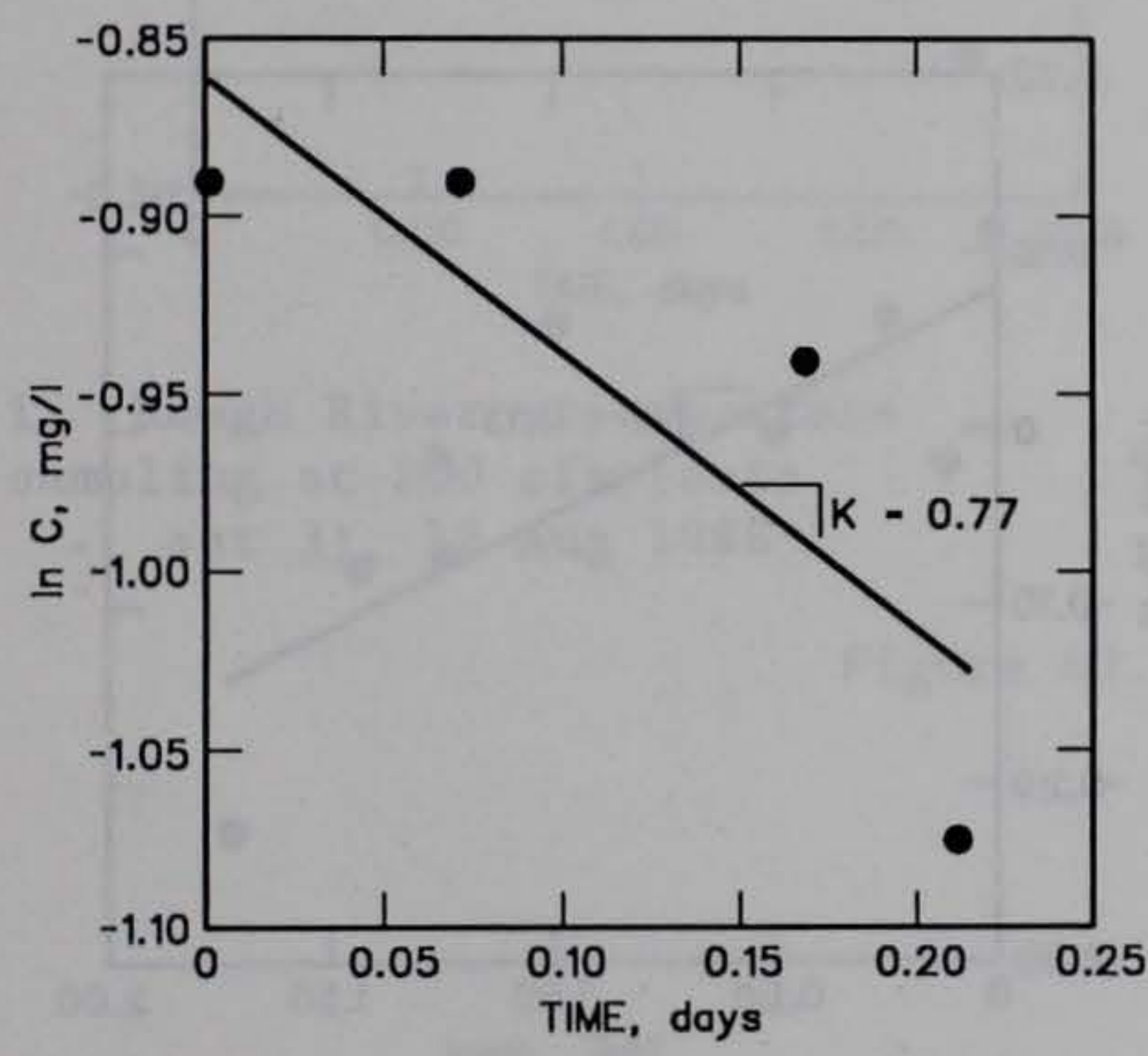

c. Fourche La Fave River time-oftravel sampling at 200 cfs (data set 2), $20 \mathrm{Jul} 1988$

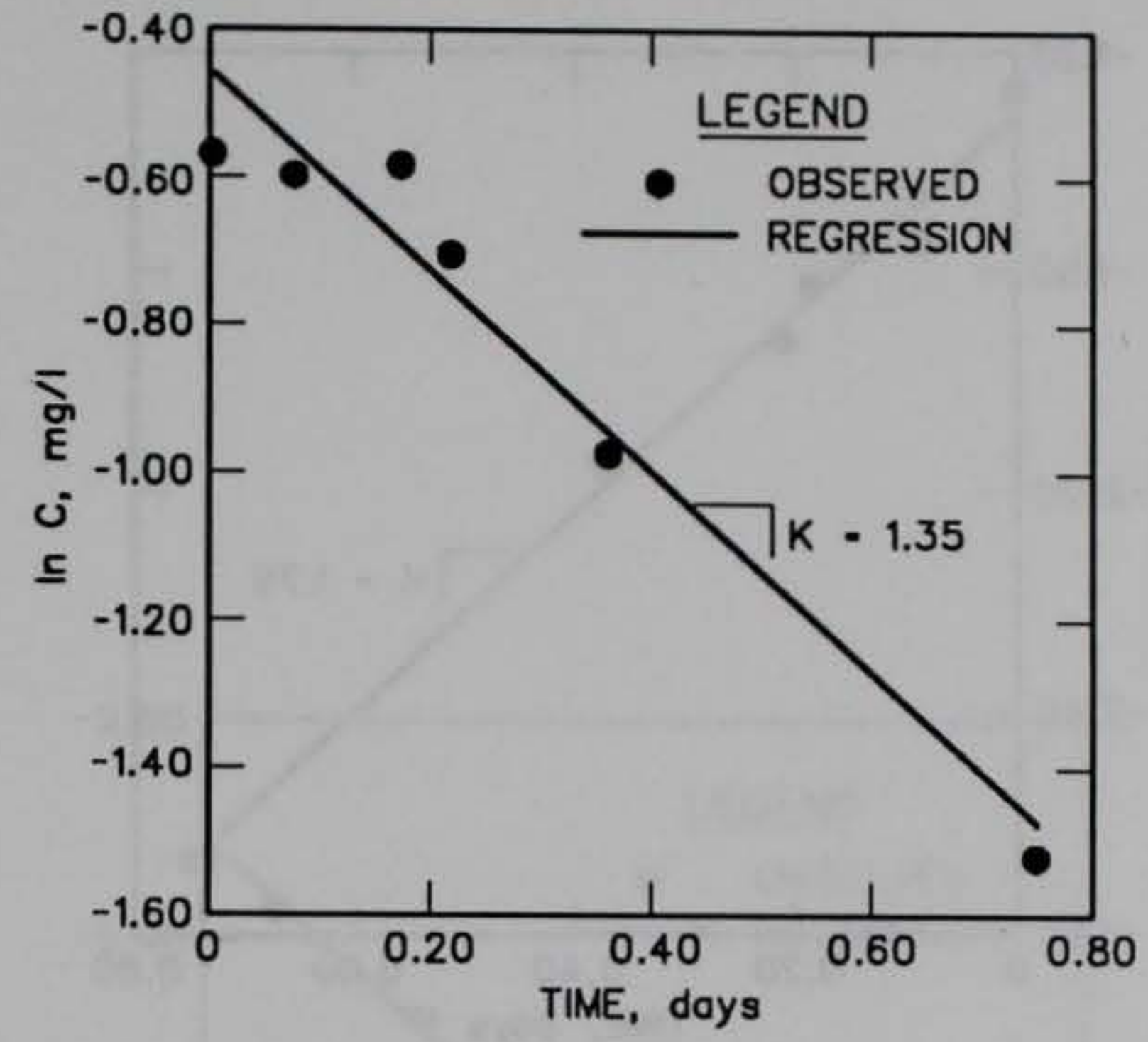

b. Fourche La Fave River steadystate sampling at $200 \mathrm{cfs}$ (data set 1), $20 \mathrm{Jul} 1988$

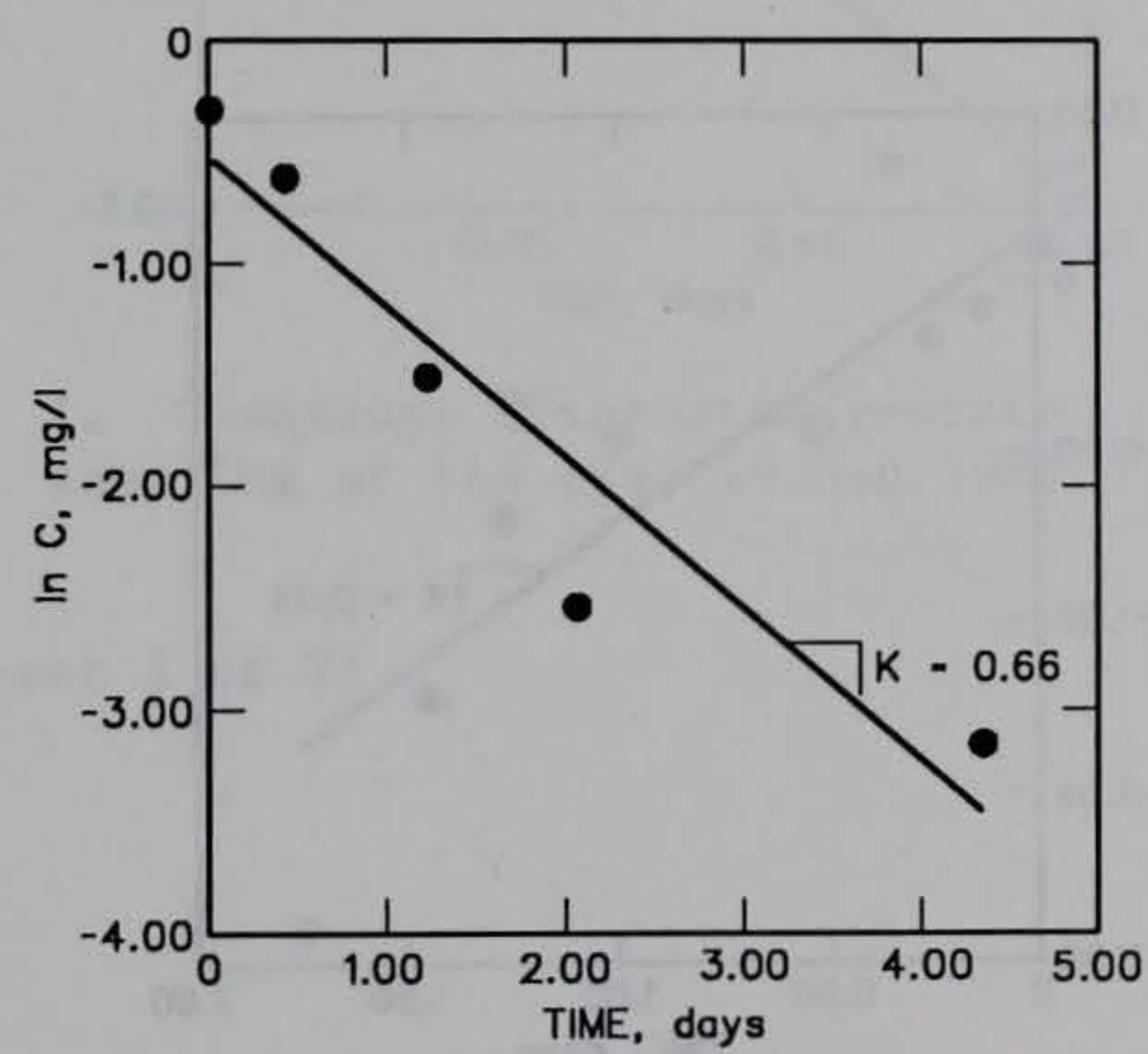

d. Fourche La Fave River steadystate sampling at 20 cfs (data set 3), 19 Jul 1988

Figure C2. Regressions for ammonia nitrogen removal rate (Sheet 1 of 3 ) 


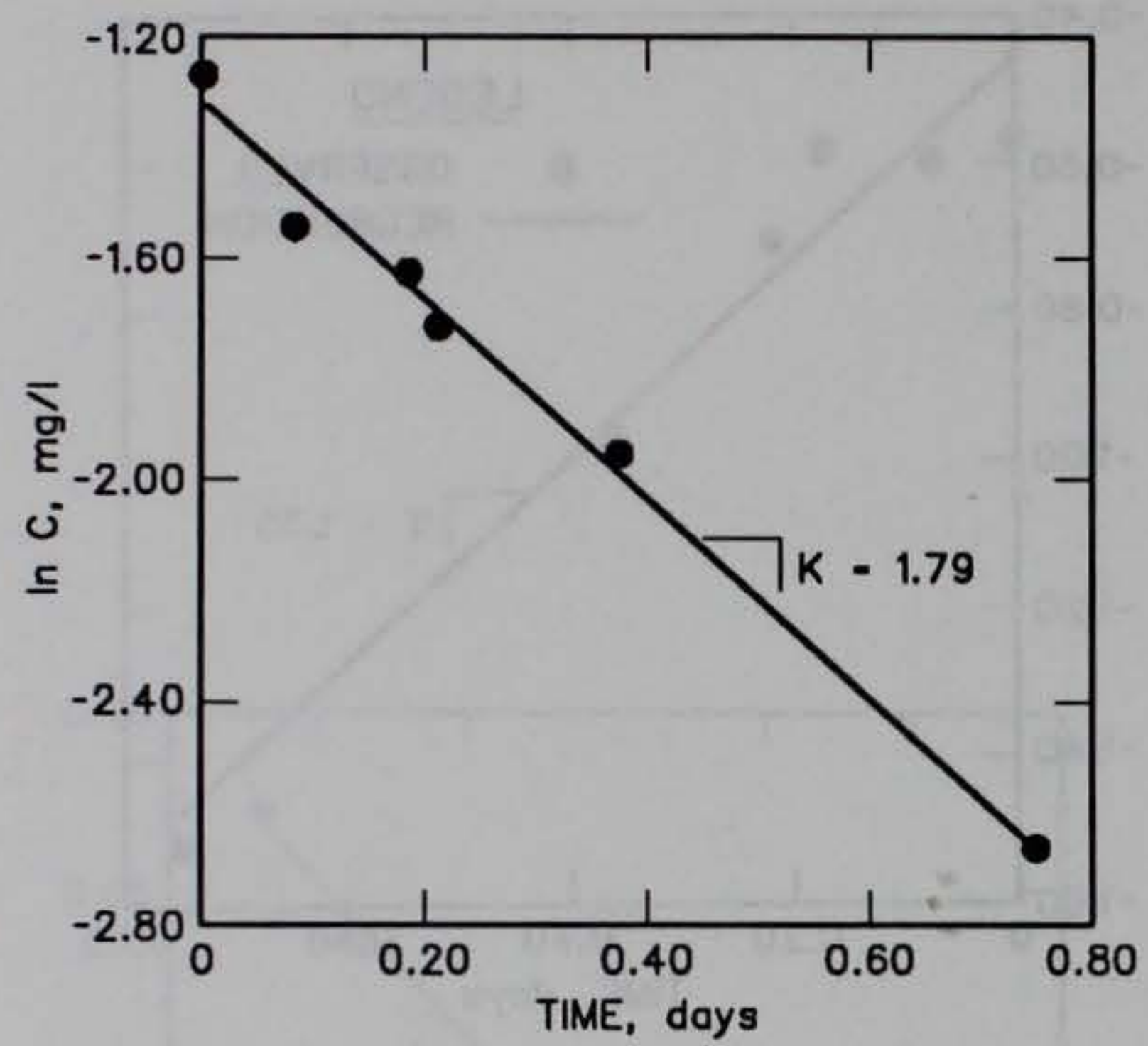

e. Fourche La Fave River steadystate sampling at $200 \mathrm{cfs}$ (data set 4), 24 Aug 1989

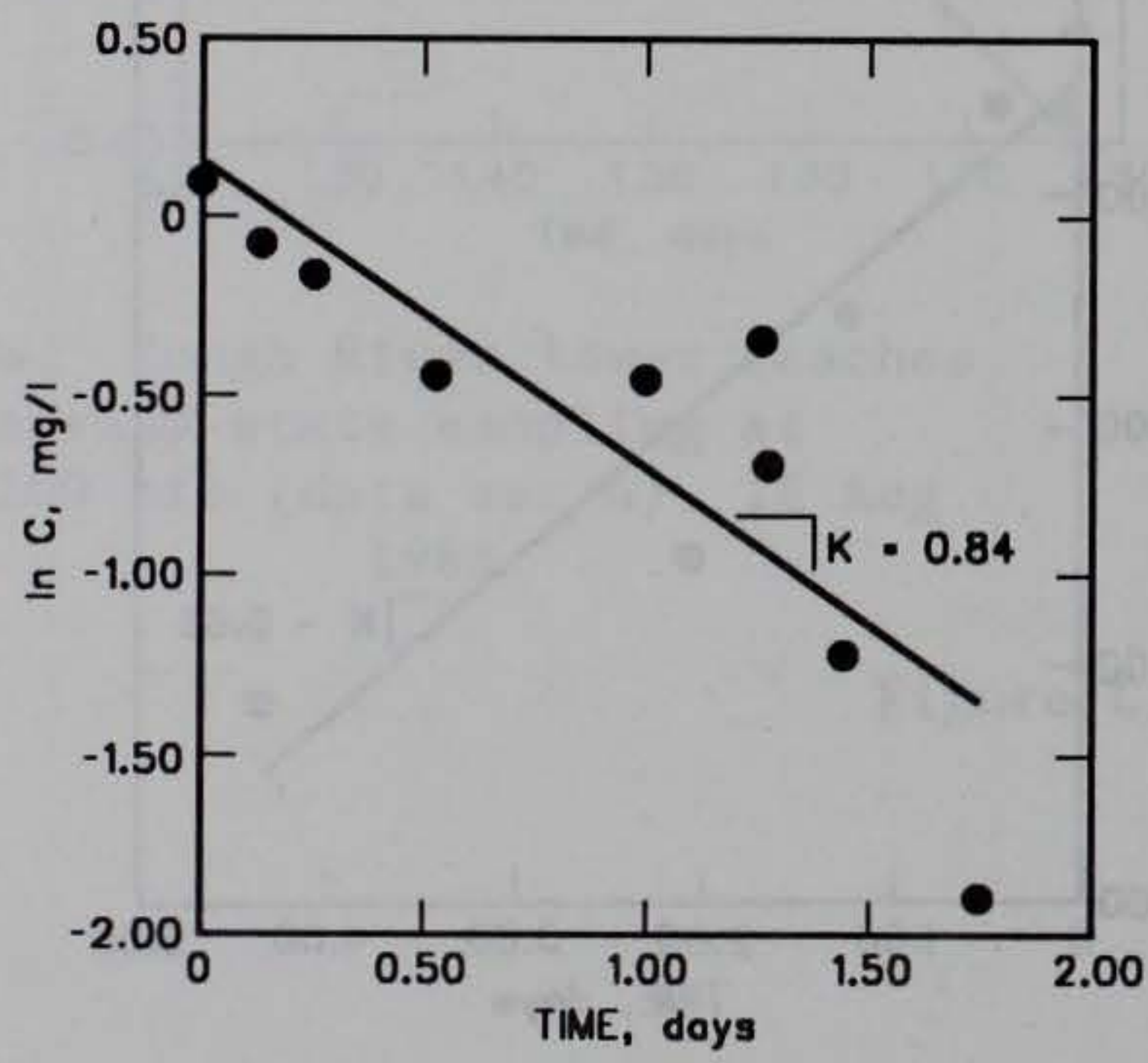

g. Rough River steady-state sampling at $20 \mathrm{cfs}$ (data set 1) 16 Aug 1988

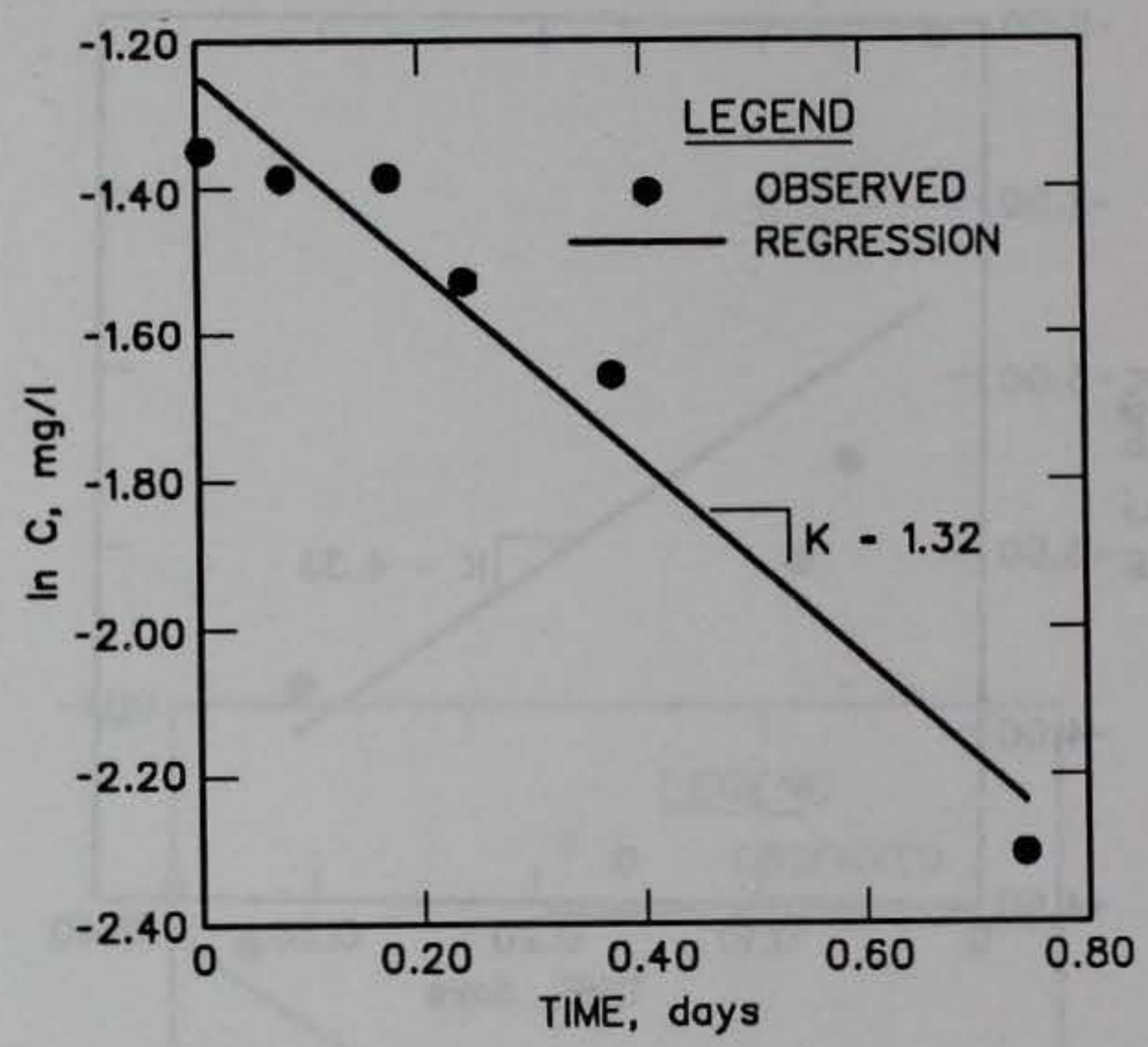

f. Fourche La Fave River time-oftravel sampling at 200 cfs (data set 5), 23 Aug 1989

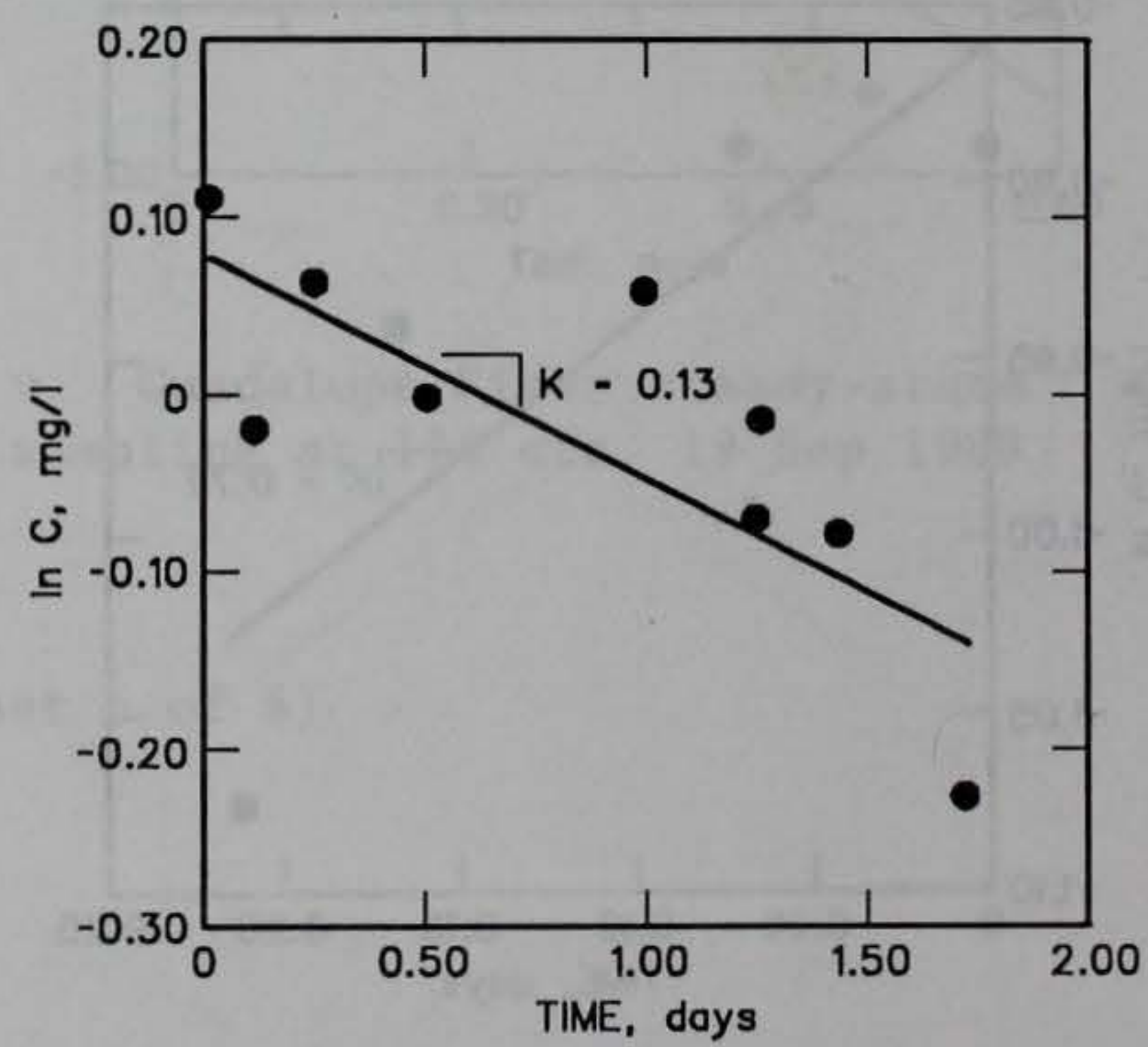

h. Rough River time-of-travel sampling at $200 \mathrm{cfs}$ (data set 2) 17 Aug 1988

Figure C2. (Sheet 2 of 3 ) 


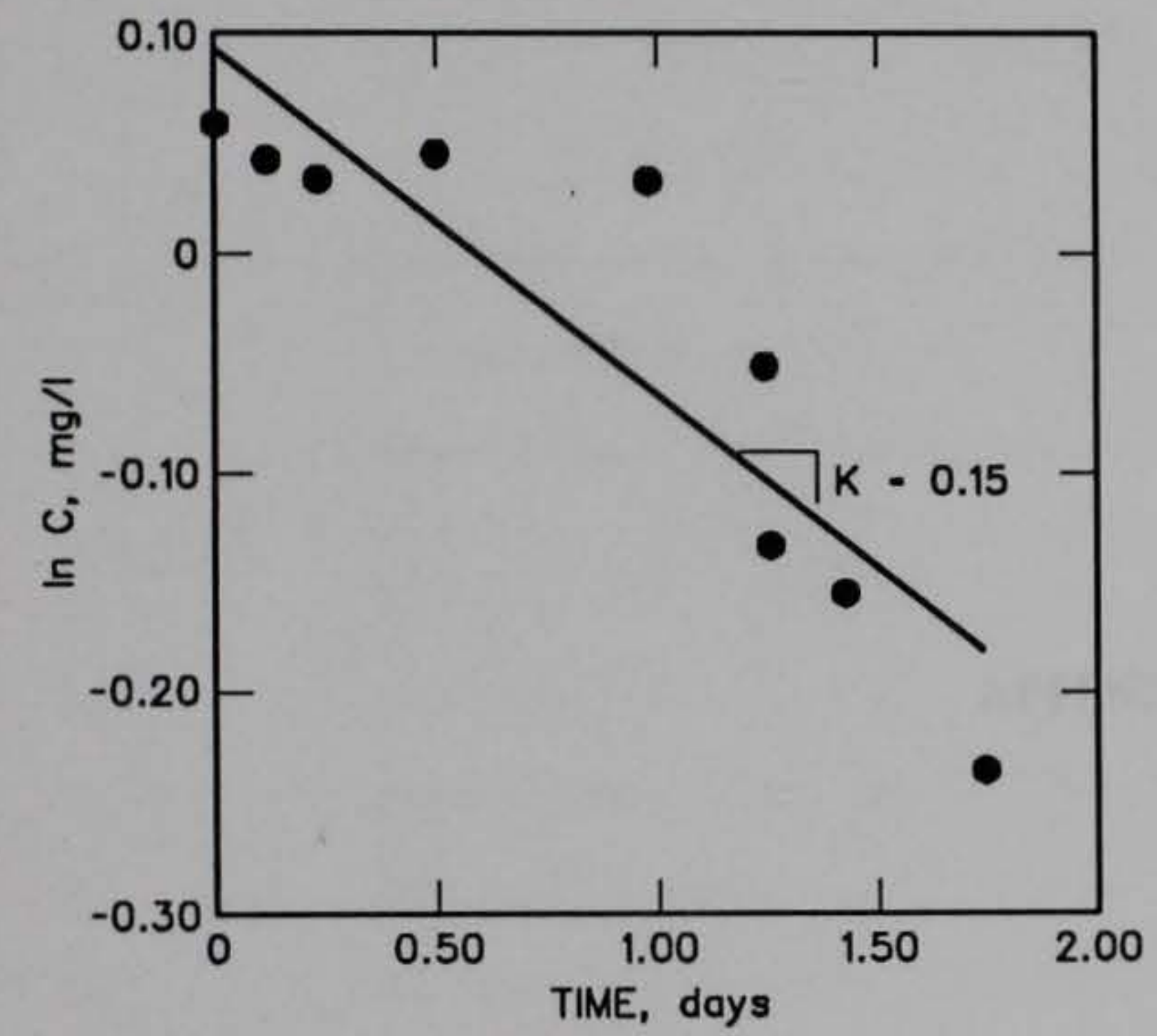

i. Rough River steady-state sampling at 200 cfs (data set 3), 18 Aug 1988

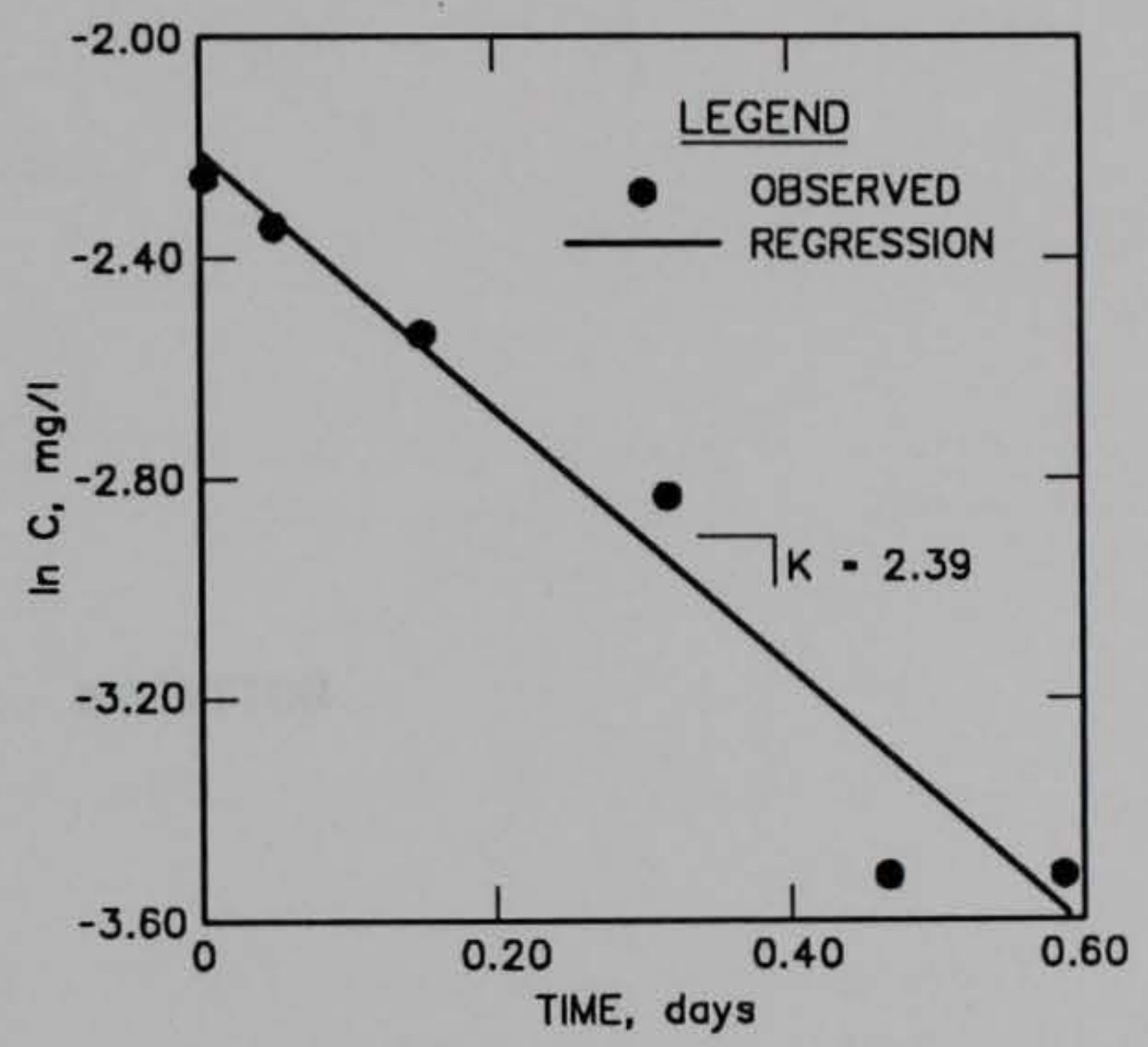

j. Guadalupe River steady-state sampling at $114 \mathrm{cfs}, 19$ Sep 1989

Figure C2. (Sheet 3 of 3 ) 
APPENDIX D: NOTATION 


\section{APPENDIX D: NOTATION}

a

$\mathrm{A}_{\mathrm{s}}$

b

c

C

$\mathrm{C}_{\mathrm{b}}$

C。

$\mathrm{C}_{\mathrm{s}}$

d

D

$\mathrm{DO}_{1 / 2}$

$\mathrm{DO}_{25}$

$\mathrm{D}_{\mathrm{m}}$

$\mathrm{D}_{\mathrm{n}}$

$\mathrm{D}_{\mathrm{s}}$

$\mathrm{D}_{\mathrm{T}}$

Do

$D^{s}$

[ $\mathrm{Fe}$ (II)]

( $\mathrm{FeS}$ )

\section{FRACT}

g

$\mathrm{H}$

$\mathrm{J}$

k

$\mathrm{k}_{\mathrm{Fe}}$

$\mathrm{k}_{\mathrm{FeS}}$

$\mathrm{k}_{\mathrm{s}}$

$\left(\mathrm{k}_{\mathrm{s}}\right)_{20}$

$\left[\mathrm{H}^{+}\right] \quad H y d r o g e n$ ion concentration, moles/l

Regression coefficient, dimensionless

Coefficient of flow for $\mathrm{K}_{2}$

Bottom planar area

Surface area of the bed control volume, $\mathrm{m}^{2}$

Exponent of flow for $\mathrm{K}_{2}$

Escape coefficient, $1 / \mathrm{ft}$

Constituent concentration

$\mathrm{Mn}^{+2}$ observed at downstream station, $\mathrm{mg} / \ell$

Concentration of reduced manganese or iron sulfide in the bed, $\mathrm{mg} / \ell$

Initial (release) $\mathrm{Mn}^{+2}$ concentration, $\mathrm{mg} / \ell$

Concentration of $\mathrm{H}_{2} \mathrm{~S}$ in the stream

Average stream depth, ft

Longitudinal dispersion

Dissolved oxygen half-saturation constant, $\mathrm{mg} / \mathrm{l}$

Molecular diffusion coefficient of $\mathrm{Mn}^{+2}$ at $25{ }^{\circ} \mathrm{C}$,

$6.88 \times 10^{-6} \mathrm{~cm}^{2} / \mathrm{sec}$

Molecular diffusion coefficient, $\mathrm{ft}^{2} /$ day

Numerical dispersion for steady-state conditions, $\mathrm{L}^{2} / \mathrm{T}$

Stream dispersion, $\mathrm{L}^{2} / \mathrm{T}$

Molecular diffusion coefficient of $\mathrm{Mn}^{+2}$ at stream temperature

$\mathrm{T}, \mathrm{cm}^{2} / \mathrm{sec}$

Molecular diffusivity of DO, $\mathrm{cm}^{2} / \mathrm{sec}$

Molecular diffusivity of $\mathrm{H}_{2} \mathrm{~S}, \mathrm{~cm}^{2} / \mathrm{sec}$

Concentration of ferrous iron, moles/ $\ell$

Iron sulfide concentration, $\mathrm{mg} / \ell$

Gravitational acceleration, $\mathrm{L} / \mathrm{T}^{2}$

Hydraulic depth, ft/ft

Volatilization, mg

Heterogeneous reation rate, $\mathrm{day}^{-1}$ (moles $\left./ \ell\right)^{-4}$

Fe $\quad 3.0 \times 10^{-12}$ moles $/ \ell \mathrm{min}^{-1}$ at $20^{\circ} \mathrm{C}$

First-order sulfide oxidation rate, day $^{-1}$

Sulfide oxidation rate, day $^{-1}$

oxidation rate at $20{ }^{\circ} \mathrm{C}$ 


\begin{tabular}{|c|c|}
\hline $\mathrm{k}_{0}$ & Homogeneous reaction rate, day $^{-1}(\operatorname{moles} / \ell)^{-3}$ \\
\hline $\mathrm{K}$ & Reaction coefficient \\
\hline $\mathrm{K}_{\mathrm{a}}$ & Nitrification rate, day $^{-1}$ \\
\hline $\mathrm{K}_{\mathrm{b}}$ & $\begin{array}{l}\text { Oxidation rate of reduced manganese or iron sulfide in the } \\
\text { bed, 1/day }\end{array}$ \\
\hline $\mathrm{K}_{\mathrm{Fe}}$ & Overall reation rate for ferrous iron \\
\hline $\mathrm{K}_{\mathrm{Mn}}$ & First-order removal rate for $\mathrm{Mn}^{+2}$ \\
\hline & $\mathrm{Mn}^{+2}$ loss rate for a specific field condition, $1 /$ day \\
\hline $\mathrm{K}_{\mathrm{s}}$ & Volatilization rate of $\mathrm{H}_{2} \mathrm{~S}$, day ${ }^{-1}$ \\
\hline $\mathrm{K}_{\mathrm{T}}$ & Reaction rate at temperature $\mathrm{T}$ \\
\hline $\mathrm{K}_{2}$ & DO stream reaeration rate, day ${ }^{-1}$ \\
\hline $\mathrm{K}_{20}$ & Reaction rate at $20^{\circ} \mathrm{C}$ \\
\hline Mn & Dissolved (reduced) manganese concentration, $\mathrm{mg} / \mathrm{l}$ \\
\hline $\mathrm{Mn}_{\mathrm{b}}$ & Reduced manganese concentration in sediment pore water, $\mathrm{mg} / \ell$ \\
\hline$[\mathrm{Mn}(\mathrm{II})$ & Dissolved (reduced) manganese concentration, moles $/ \ell$ \\
\hline$[\operatorname{Mn}(I V)]$ & Particulate (oxidized) manganese concentration, moles/ $\ell$ \\
\hline $\mathrm{M}^{\circ}$ & Molecular weight of $\mathrm{DO}, \mathrm{g} / \mathrm{mole}$ \\
\hline$M^{\mathbf{s}}$ & Molecular weight of $\mathrm{H}_{2} \mathrm{~S}, \mathrm{~g} / \mathrm{mole}$ \\
\hline $\mathrm{n}$ & Manning's coefficient \\
\hline$\left[\mathrm{OH}^{-}\right]$ & Hydroxide ion concentration, moles/ $\ell$ \\
\hline $\mathrm{P}$ & Point load \\
\hline $\mathrm{P}_{0}$ & Partial pressure of oxygen, atm \\
\hline Q & Flow rate \\
\hline s & Water surface or streambed slope, nondimensional \\
\hline S & $\begin{array}{l}\text { Rate of change in concentration resulting from transformation } \\
\text { or chemical reactions }\end{array}$ \\
\hline & Sulfide concentration in the form of $\mathrm{HS}^{-}, \mathrm{mg} / \ell$ \\
\hline Sc & Schmidt number $(\nu / D)$, nondimensional \\
\hline $\mathrm{S}_{\mathrm{e}}$ & Slope of energy gradient \\
\hline $\mathrm{S}_{\mathrm{o}}$ & Slope of streambed, $\mathrm{ft} / \mathrm{ft}$ \\
\hline$t$ & Travel time to station, days \\
\hline $\mathrm{T}$ & Ambient stream temperature, ${ }^{\circ} \mathrm{C}$ \\
\hline$t_{f}$ & Flow time through reach, days \\
\hline $\mathrm{u}$ & Average stream velocity, $\mathrm{m} / \mathrm{sec}$ \\
\hline $\mathrm{u}_{*}$ & Shear velocity $(\sqrt{\mathrm{gHs}}), \mathrm{L} / \mathrm{T}$ \\
\hline $\mathrm{U}$ & Stream mean velocity \\
\hline V & Control volume of fixed volume \\
\hline
\end{tabular}




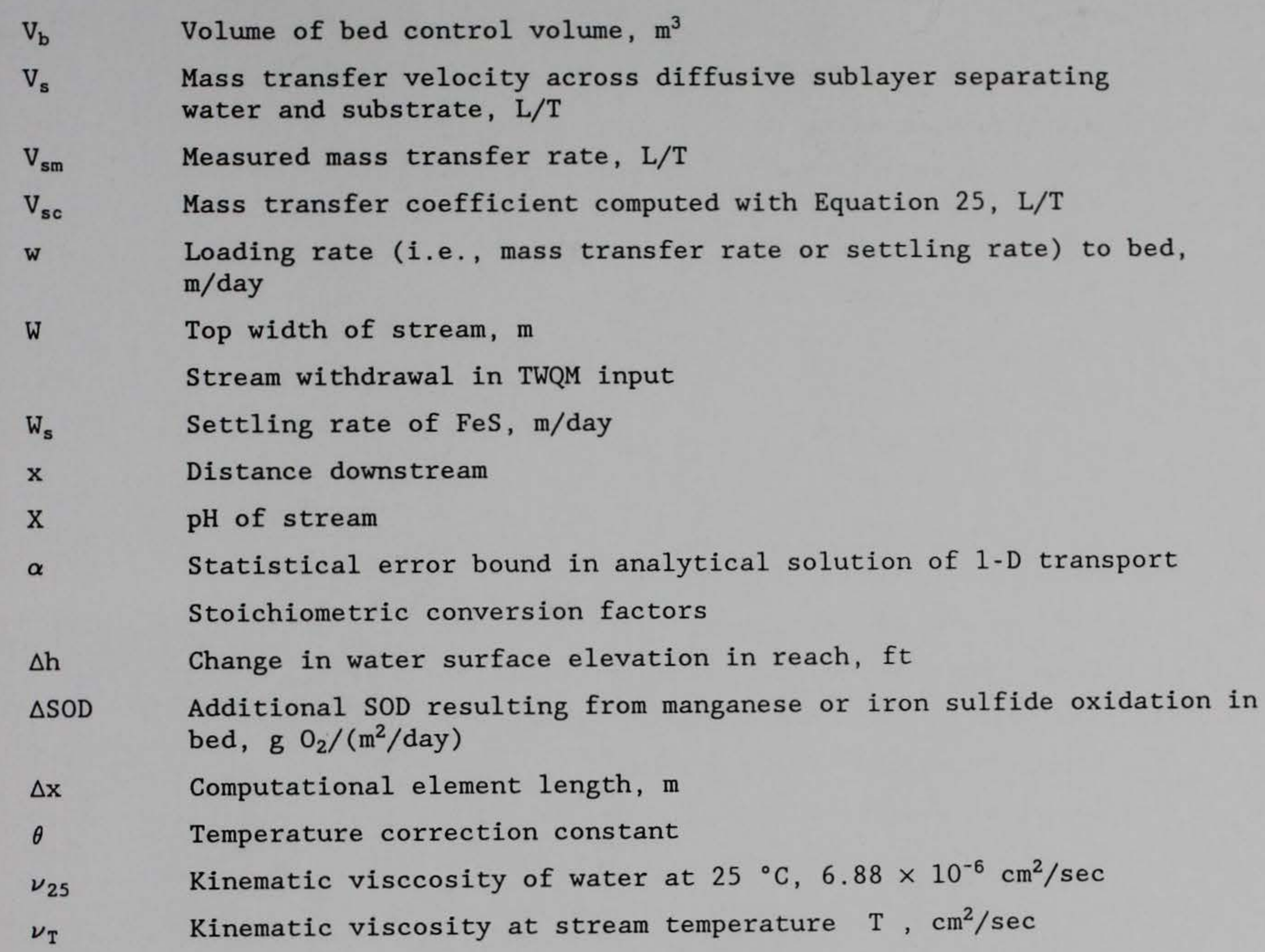

